\title{
Cardiovascular abnormalities in subjects with type 2 diabetes mellitus detected by screening
}

Citation for published version (APA):

Kruijshoop, M. (2004). Cardiovascular abnormalities in subjects with type 2 diabetes mellitus detected by screening. [Doctoral Thesis, Maastricht University]. Maastricht University. https://doi.org/10.26481/dis.20041126mk

Document status and date:

Published: 01/01/2004

DOI:

10.26481/dis.20041126mk

Document Version:

Publisher's PDF, also known as Version of record

\section{Please check the document version of this publication:}

- A submitted manuscript is the version of the article upon submission and before peer-review. There can be important differences between the submitted version and the official published version of record.

People interested in the research are advised to contact the author for the final version of the publication, or visit the DOI to the publisher's website.

- The final author version and the galley proof are versions of the publication after peer review.

- The final published version features the final layout of the paper including the volume, issue and page numbers.

Link to publication

\footnotetext{
General rights rights.

- You may freely distribute the URL identifying the publication in the public portal. please follow below link for the End User Agreement:

www.umlib.nl/taverne-license

Take down policy

If you believe that this document breaches copyright please contact us at:

repository@maastrichtuniversity.nl

providing details and we will investigate your claim.
}

Copyright and moral rights for the publications made accessible in the public portal are retained by the authors and/or other copyright owners and it is a condition of accessing publications that users recognise and abide by the legal requirements associated with these

- Users may download and print one copy of any publication from the public portal for the purpose of private study or research.

- You may not further distribute the material or use it for any profit-making activity or commercial gain

If the publication is distributed under the terms of Article $25 \mathrm{fa}$ of the Dutch Copyright Act, indicated by the "Taverne" license above, 
Cardiovascular abnormalities in subjects with type 2 diabetes mellitus detected by screening 
The study presented in this thesis was performed at the Cardiovascular Research Institute Maastricht (CARIM)

(C) Margriet Kruijshoop, Maastricht 2004

ISBN 90-9018058-3

Printed by Ponsen \& Looijen BV 


\title{
Cardiovascular abnormalities in subjects with type 2 diabetes mellitus detected by screening
}

\author{
Proefschrift \\ ter verkrijging van de graad van doctor \\ aan de Universiteit Maastricht, \\ op gezag van de Rector Magnificus, \\ Prof. mr. G.P.M.F. Mols \\ volgens het besluit van het College van Decanen, \\ in het openbaar te verdedigen \\ op vrijdag 26 november 2004 om 12.00 uur \\ door
} Margriet Kruijshoop 


\section{Promotor:}

Prof. Dr. T.W.A. de Bruin

\section{Copromotores:}

Dr. ir. E.E. Blaak

Dr. ir. E.J.M. Feskens (RIVM, Bilthoven)

\section{Beoordelingscommissie:}

Prof. Dr. P.W. de Leeuw (voorzitter)

Prof. Dr. A.P.G. Hoeks

Prof. Dr. C.D.A. Stehouwer

Prof. Dr. H. Struijker-Boudier

The research described in this thesis was supported by grants of the Netherlands Organisation for Scientific Research (ZonNW 940-35-034) and the Dutch Diabetes Research Foundation (DFN 98.901).

Financial support by the Netherlands Heart Foundation and the Dutch Diabetes Research Foundation for the publication of this thesis is gratefully acknowledged.

Printing of this thesis was financially supported by Eli Lilly Nederland, Novartis Pharma BV, Novo Nordisk Farma BV, Boehringer Ingelheim bv, Merck BV, Ferring BV, SanofiSynthelabo BV, Bristol-Myers Squibb B.V., Pfizer bv, Bayer Health Care, Servier Nederland BV 


\section{Contents}

List of abbreviations

$\begin{array}{lll}\text { Chapter 1: } & \text { General introduction } & 9\end{array}$

Chapter 2: Subjects, methods, and design of the CODAM study 45 Appendices with Chapter $2 \quad 71$

Chapter 3: $\quad$ Study on lifestyle-intervention and impaired glucose tolerance Maastricht (SLIM): design and screening results Diabetes Research and Clinical Practice 2003; 61: 49-58

Chapter 4: Validation of capillary glucose measurements to detect type 2 diabetes mellitus in the general population

Clinica Chimica Acta 2004; 341: 33-40

Chapter 5: Increased arterial stiffness in recently diagnosed type 2 diabetes mellitus

Submitted for publication

Chapter 6: Increased pulse pressure is associated with metabolic syndrome and type 2 diabetes

Submitted for publication

Chapter 7: General discussion

Curriculum Vitae

List of publications 


\section{List of abbreviations}

$A=$ diastolic lumen area

$\Delta A=$ change in cross-sectional area from diastole to systole

$\mathrm{ABI}=$ ankle/brachial index

$A C E$ = angiotensin converting enzyme

AGEs $=$ advanced glycosylation end-products

ApoB $=$ apolipoprotein B

$\mathrm{b}=$ beats

$\mathrm{BMI}=$ body mass index

$\mathrm{C}=$ capillary plasma glucose concentration

C3 $=$ complement factor 3

$\mathrm{cm}=$ centimeter

$\mathrm{CCA}=$ common carotid artery

$\mathrm{CHD}=$ coronary heart disease

$\mathrm{Cl}=$ confidence interval

$\mathrm{COM}=$ compliance

conc $=$ concentration

CRP $=$ C-reactive protein

$\mathrm{CVD}=$ cardiovascular disease

$\mathrm{d}=$ diameter

$\Delta \mathrm{d}=$ distension

DIS $=$ distensibility

DBP = diastolic blood pressure

DIALOG = DIAbetes, Lipids, Obesity, Genetics

$\mathrm{DM}=$ type 2 diabetes mellitus

$E=$ Young's elastic modulus

$E C G$ = electrocardiogram

ELISA = enzyme-linked immunosorbent assay

$\mathrm{ESRD}=$ end-stage renal disease

$\mathrm{FCH}=$ familial combined hyperlipidemia

$F F A=$ free fatty acids

$\mathrm{FFM}=$ fat free mass

$\mathrm{g}=$ gram

$\mathrm{GAD}=$ glutamic acid decarboxylase

$\mathrm{h}=$ hour

HbA1c $=$ glycosylated haemoglobin

$\mathrm{HDL}=$ high density lipoprotein

HK-G6PD = hexokinase glucose-6-phosphate dehydrogenase

HOMA $=$ homeostasis model assessment

HPLC $=$ high performance liquid chromatography

IDL = intermediate density lipoprotein

IFG = impaired fasting glucose

IGT = impaired glucose tolerance

IL-6 = interleukin-6 
IMT = intima-media thickness

k = kappa

$\mathrm{kg}=$ kilogram

$\mathrm{L}=$ liter

$\mathrm{LDL}=$ low density lipoprotein

$\mathrm{LVH}=$ left ventricular hypertrophy

$\mathrm{m}=$ meter

$\min =$ minimum

$\mathrm{MAP}=$ mean arterial pressure

$\max =$ maximum

$\mathrm{MI}=$ myocardial infarction

$\mathrm{MJ}=$ megajoules

$\mathrm{ml}=$ milliliter

$\mathrm{mm}=$ millimetre

$\mathrm{MPa}=$ megapascale

$\mathrm{N}=$ number

$\mathrm{NaF}=$ natrium fluoride

NEFA $=$ non-esterified fatty acids

NGT $=$ normal glucose tolerance

$\mathrm{NO}=$ nitric oxide

OGTT $=$ oral glucose tolerance test

$\mathrm{OR}=$ odds ratio

$\Delta \mathrm{p}=$ brachial pulse pressure

$\mathrm{PAl}-1$ = plasminogen activator inhibitor 1

$\mathrm{PI} 3 \mathrm{~K}=$ phosphatidyl 3-kinase

$\mathrm{PP}=$ pulse pressure

PTCA = percutaneous transluminal balloon dilation

PVD = peripheral vascular disease

PWV = pulse wave velocity

$\mathrm{SBP}=$ systolic blood pressure

$\mathrm{SD}=$ standard deviation

sICAM-1 = soluble intercellular adhesion molecule 1

TOD $=$ target organ damage

TODcrea $=$ target organ damage defined according to concentration of plasma creatinine

TODimt $=$ target organ damage defined according to intima-media thickness

TODlvh = target organ damage defined according to the presence of left ventricular hypertrophy

TODmicro $=$ target organ damage defined according to the presence of microalbuminuria

TODpvd $=$ target organ damage defined according to the presence of peripheral vascular disease

TODsicam = target organ damage defined according to concentration of plasma soluble intercellular adhesion molecule

$\mathrm{V}=$ venous plasma glucose concentration

VCAM-1 = vascular adhesion molecule- 1

VLDL = very low density lipoprotein 
$\mathrm{W}=$ watt

WHR $=$ waist/hip ratio 
CHAPTER 1

General introduction 


\section{1: Diabetes mellitus}

1.1.1: Type 2 diabetes mellitus

1.1.2: Prevalence and costs

1.1.3: Diagnosis

1.1.4: Pathogenesis

1.1.5: Risk factors for type 2 diabetes

\section{2: Cardiovascular disease}

1.2.1: Description of risk factors

1.2.2: Risk assessment scores

\section{3: Atherosclerosis}

\subsection{1: Plaque vulnerability}

1.3.2: Role of endothelial dysfunction and permeability in early atherosclerosis

1.3.3: Role of cell adhesion molecules in early atherosclerosis

1.3.4: Role of blood flow in early atherosclerosis

1.3.5: Lipoprotein oxidation in early atherosclerosis

1.3.6: Conclusion

\section{4: Surrogate markers atherosclerosis}

1.4.1: Intima-media thickness

1:4:C: Arteriai sumess

1.4.3: Prospective studies

1.5: Risk factors for both type 2 diabetes and cardiovascular disease

1.5.1: Risk factors

1.5.2: Metabolic syndrome

1.5.3: Obesity

\section{6: Conclusion}

\section{7: Outline of the thesis}




\section{1: Diabetes mellitus}

Diabetes mellitus is a chronic metabolic disease which is characterized by chronic hyperglycemia. Five to ten percent of patients have type 1 diabetes, formerly known as insulin-dependent diabetes mellitus or juvenile onset diabetes mellitus (1). Type 1 diabetes represents insulin deficiency or absence of insulin primarily due to autoimmune destruction of pancreatic islet beta-cells. In $85-90 \%$ of the subjects with type 1 diabetes, islet cell autoantibodies, and/or autoantibodies to insulin and autoantibodies to glutamic acid decarboxylase (GAD) are present which identify the autoimmune processes that lead to beta-cell destruction $(1,2)$. Subjects with type 1 diabetes require insulin for their survival to prevent the development of ketoacidosis, coma and death. Type 2 diabetes mellitus represents the most common form, responsible for over $85 \%$ of the cases in the Netherlands (www.rivm.nl/vtvdata/site_kompas). Other specific types of diabetes mellitus such as type 3 and type 4 refer to specific situations such as pancreatic disease, surgery, and gestational diabetes $(1,2)$.

\subsection{1: Type 2 diabetes mellitus}

Type 2 diabetes mellitus represents a metabolic disorder of multiple aetiology, which is characterized by chronic hyperglycemia caused by impaired insulin action and secretion, either of which may be the predominant feature in the pre-diabetic state (1). These impairements can result in disturbances in carbohydrate, fat and protein metabolism, which can result in long-term damage, dysfunction and failure of various organs. The pathological and functional changes caused by hyperglycemia may be present long before the diagnosis of type 2 diabetes is made, but symptoms of type 2 diabetes are often insidious at the beginning, or even absent (1). Long-term effects of diabetes mellitus include progressive development of specific microvascular complications including retinopathy which potentially leads to blindness, nephropathy which can lead to renal failure, or neuropathy which may affect peripheral nerves or autonomic dysfunction. Furthermore, patients with type 2 diabetes have an increased incidence of macrovascular disease, such as coronary heart disease (CHD), stroke or cerebrovascular accidents, and peripheral vascular disease (PVD) (2). Approximately $60-70 \%$ of patients with type 2 diabetes die from vascular disease such as myocardial infarction or stroke (3). The main theory to explain the increased risk of cardiovascular disease (CVD) in type 2 diabetes holds that the increased risk is caused by an increased rate of atherosclerosis.

\subsection{2: Prevalence and costs}

Increased incidence and prevalence of obesity, arising from energy-rich diets and sedentary lifestyles, drives a global pandemic of type 2 diabetes (4). The prevalence of type 2 diabetes worldwide is expected to increase from its present level of 150 million to 300 million by 2025 . These figures however, represent only clinically diagnosed diabetes, and even more cases of diabetes remain undiagnosed and untreated. 
Moreover, approximately 20 to $25 \%$ of the subjects in Western populations have the metabolic syndrome after adjustment for age $(1,5)$. Subjects with the metabolic syndrome are at high risk of future type 2 diabetes, and therefore can be considered to represent a pre-diabetic state. The costs of health care of subjects with diabetes increases with the onset of complications (6). In a United States study, Kaiser Permanente North-west Division (KPNW), renal and cardiovascular complications were the most prevalent in subjects with diabetes and were associated with particularly high costs: an increase of $\$ 9385$ after the occurrence of a major cardiovascular event, and $\$ 15,675$ for renal transplantation over the costs of uncomplicated diabetes (6).

The Cost of Diabetes in Europe - Type II (CODE-2) study also showed that atherosclerosis in type 2 diabetes accounts for approximately one third of the total health care costs related to the disease in the eight European countries that participated in the CODE-2 study, including the Netherlands (7). Overall, the presence of microvascular complications results in an increase of $70 \%$ of the health costs, and the presence of macrovascular complications results in an increase of $100 \%$, compared to people without evidence of complications (7). Furthermore, the presence of both microvascular and macrovascular complications increases the total costs of management 3.5 times compared to those without evidence of complications (7). The CODE-2 study also showed that the total direct medical costs of type 2 diabetes was estimated at $€ 29$ billion a year and that the average yearly cost per patient was $€ 2834$ a year in 1999 (8). The Netherlands were found to have the lowest expenditure per patient, i.e. $€ 1827$, which accounted for $1.6 \%$ of the total healthcare expenditure. The prevalence of type 2 diabetes in the Netherlands was $1.7 \%$ which is the lowest prevalence found in the CODE-2 study (8).

Tabel 1: Glucose tolerance status according to the 1999 WHO criteria (1)

Whole blood glucose Plasma glucose

\begin{tabular}{cccc}
\hline $\begin{array}{c}\text { venous } \\
(\mathrm{mmol} / \mathrm{l})\end{array}$ & $\begin{array}{c}\text { capillary } \\
(\mathrm{mmol} / \mathrm{l})\end{array}$ & $\begin{array}{c}\text { venous } \\
(\mathrm{mmol} / \mathrm{l})\end{array}$ & $\begin{array}{c}\text { capillary } \\
(\mathrm{mmol} / \mathrm{l})\end{array}$ \\
\hline 6.1 & $\geq 6.1$ & $\geq 7.0$ & $\geq 7.0$ \\
$\geq 10.0$ & $\geq 11.1$ & $\geq 11.1$ & $\geq 12.2$ \\
& & & \\
$<6.1$ & $<6.1$ & $<7.0$ & $<7.0$ \\
$6.7-<10.0$ & $7.8-<11.1$ & $7.8-<11.1$ & $8.9-<12.2$ \\
& & & \\
$5.6-<6.1$ & $5.6-<6.1$ & $6.1-<7.0$ & $6.1-<7.0$ \\
$<6.7$ & $<7.8$ & $<7.8$ & $<8.9$ \\
& & & $<6.1$ \\
$<5.6$ & $<5.6$ & $<6.1$ & $<8.9$ \\
$<6.7$ & $<7.8$ & $<7.8$ & \\
& & &
\end{tabular}

\subsection{3: Diagnosis}

In most cases, a clinician diagnoses type 2 diabetes by the severity of symptoms and overt hyperglycemia (1). However, type 2 diabetes can be present without symptomos. 
Therefore, an oral glucose tolerance test (OGTT) is recommended in epidemiological studies. This test measures blood or plasma glucose concentrations in the fasting state and at regular intervals up to $2 \mathrm{~h}$ after a $75-\mathrm{g}$ oral glucose load. The WHO has adjusted the diagnostic criteria for interpretation of the results in whole blood and plasma in 1999 (1). The largest change was the lowering of the cut-off value of fasting glucose concentration from $7.8 \mathrm{mmol} / /$ to $7.0 \mathrm{mmol} / \mathrm{l}$. In addition to the criteria for type 2 diabetes mellitus, the 1999 WHO criteria also defined cut-offs for impaired glucose tolerance (IGT) and impaired fasting glucose (IFG) (Table 1). It should be noted that the American Dabetes Association (ADA) recently has proposed to lower the cut-off value for IFG to optimize its sensitivity and specificity to predict future diabetes (9). A debate has started what the benefits and consequences would be for patients and health care costs if this proposal is accepted (10-12).

\subsection{4: Pathogenesis}

Insulin resistance, defined as a decreased ability of insulin to stimulate glucose uptake in peripheral tissues, is a key pathogenic parameter observed in the natural history of type 2 diabetes (13). Another key feature is beta-cell failure, i.e. the inability of the pancreatic beta-cell to adequately secrete insulin relative to the insulin needs of the body (14). It is believed that the pathogenesis of type 2 diabetes starts with a gradual increase in insulin resistance, which results in compensatory hyperinsulinemia. This state is probably maintained until pancreatic secretory defects occur. Consequently, once beta-cell failure occurs, insulin resistance cannot be compensated any more. Furthermore, increased hepatic gluconeogenesis may occur (15). Both fasting and postprandial hyperglycemia result, which is the state of overt diabetes.

It can take many years before type 2 diabetes has fully developed. Both insulin resistance and beta-cell failure are caused by a combination of genetic and environmental factors (16). Environmental factors, such as lifestyle habits (i.e. obesity. physical inactivity and dietary intake), intrauterine malnutrition and toxins may enhance the progression to type 2 diabetes (16). When insulin resistance cannot be compensated any more by an increase in insulin secretion because of impaired beta cell function, impaired glucose tolerance can occur, which represents the pre-diabetic stage. It is also at this stage where clustering of risk factors, i.e. the metabolic syndrome, is observed. Therefore, insulin resistance may be present many years before the diagnosis of type 2 diabetes and subjects may be predisposed to accelerated atherosclerosis (17). It is this stage in the ratural history towards type 2 diabetes where prevention trials are currently addressing the need to reduce insulin resistance or insulin secretion defects, both by pharmacological and nonpharmacological means, in the hope that type 2 diabetes can be prevented or delayed (18-22). A schematic representation of the natural history of type 2 diabetes, with insulin resistance, compensatory hyperinsulinemia, and associated risk factors, is outlined in figure 1. 


\section{Proposed Metabolic Observations in the Natural History of Type 2 Diabetes}

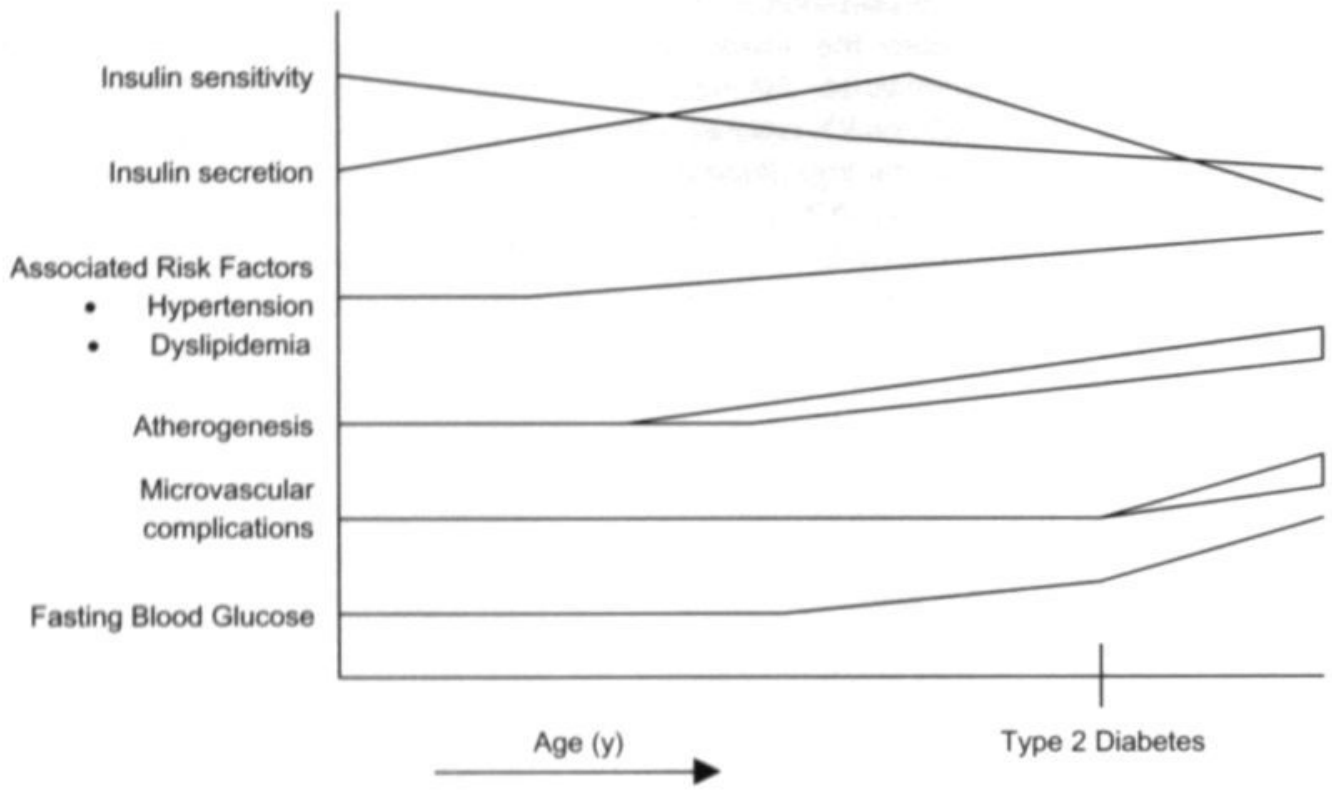

Figure 1: Schematic representation of clinical and laboratory findings in the natural history of type 2 diabetes (15).

\subsection{5: Risk factors for type 2 diabetes}

Genetic, environmental, and metabolic risk factors all contribute to the development of type 2 diabetes mellitus (23). A family history of diabetes mellitus, age, obesity, and physical inactivity identify those individuals at highest risk. Minority populations are also at higher risk, because of family history and genetics in combination with adaptation to Western environmental influences of poor dietary and exercise habits (23). Women with a history of gestational diabetes, as well as their children, are also at greater risk for progressing to type 2 diabetes mellitus. Most metabolic risk factors leading to type 2 diabetes are already present in the early insulin resistant conditions. These include hyperinsulinemia, atherogenic dyslipidemia, glucose intolerance, hypertension, a prothrombotic state, hyperuricemia, and polycystic ovary syndrome. Clinical and observational studies have demonstrated the adverse effects of obesity and sedentary lifestyle, as well as the benefits of moderate weight loss and related behaviours, including increased levels of physical activity, in maintaining metabolic control and reducing the incidence of type 2 diabetes (24). Awareness of risk factors for developing type 2 diabetes will promote screening, early detection of type 2 diabetes, and treatment in high-risk populations. This will decrease both microvascular and macrovascular complications. 


\section{2: Cardiovascular disease}

Cardiovascular disease (CVD) is a term that covers a range of diseases of the heart and large blood vessels. CVD is the major cause of premature death in most European countries and in the United States $(25,26)$. In the Netherlands, CVD provides the largest contribution to total mortality for many years now (27). In the year $2002,34 \%$ of total mortality was ascribed to CVD, with equal representation in men and women.

CVD can be divided into different disease categories. The five largest categories in the Netherlands are ischaemic heart disease $(32.7 \%)$, other heart diseases including heart failure $(26.6 \%)$, cerebrovascular disorders $(25.3 \%)$, atherosclerosis and/or hypertension $(4.8 \%)$, and arterial vascular disease $(4.3 \%)(27)$. A major risk factor for CVD is an unhealthy lifestyle, reflected by less healthy dietary habits (28) and less physical activity (29-31). Other CVD risk factors include increasing age (32-34), male gender $(35,36)$, obesity (37-41), previous history of CVD (42-45), positive family history of CHD (36,46-48), smoking (49), hypertension $(34,50-53)$, elevated total $(47,54,55)$ and low-density lipoprotein (LDL) cholesterol (55-59), reduced high-density lipoprotein (HDL) cholesterol (59-61), and diabetes mellitus $(57,62)$. More recently, several novel risk factors have been found such as small dense LDL particles $(56,63,64)$, hypertriglyceridemia (65-67), hyperinsulinemia (68-70), elevated apolipoprotein B concentrations (70-75), decreased Ankle/Brachial Index (26,76-78), microalbuminuria $(79,80)$, elevated C-reactive protein $(22,81-84)$, and elevated homocysteine $(85-92)$.

\subsection{1: Description of risk factors}

Age: The age-associated changes in cardiac and vascular properties reduce the threshold that results in clinically significant signs and symptoms of CVD (32). In older individuals for example, the specific pathophysiological mechanisms that cause clinical disorders have more effect, because of vascular rarefaction (fewer resistance vessels) and decreased arteriolar cross-sectional area that will result in increased peripheral resistance (50). Therefore, age is considered a major risk factor per se for cardiovascular disease.

Male gender: Male gender is a well-known risk factor for CVD. By the age of 60, every one out of five men and one out of seventeen women have some form of $\mathrm{CHD}$ in industrialized societies such as Northern Europe and North America (35). In the Nijmegen Cohort Study, the incidence of $\mathrm{CHD}$ was $8.6 \%$ in men and $3.0 \%$ in women during 18 years of follow-up (36). Also, the website of "Nationaal Kompas Volksgezondheid" (www.rivm.nl/vtv/data/site_kompas) indicates that the most recent incidence numbers for CHD are 5.92 per 1000 men and 4.36 per 1000 women in the Netherlands. These studies all indicate the higher risk for CVD in men compared to women.

Body weight and obesity: Many risk factors, such as age, race and the presence of certain diseases determine the degree of obesity (37). With an increase in prevalence of risk factors, the risk of obesity increases. Furthermore, severe obesity in both men and women in all age groups, increases the risk of death from all causes, CVD, cancer, and other diseases (37). Obesity is a modifiable cardiovascular risk factor that is far more prevalent in type 2 diabetes than in the general population. However, little or no correlations were demonstrated between fat mass and coronary atherosclerosis in 
angiographic and post mortem studies, except in those with central (upper-body) obesity (41). Central obesity is strongly associated with traditional risk factors for CVD such as type 2 diabetes, hypertension and dyslipidemia, and contributes to earlier or more severe disease manifestations (41). Therefore, central obesity is a stronger risk factor of CVD than obesity per se.

Previous history of cardiovascular disease (CVD): The presence of coronary heart disease strongly predicts coronary events (43). Furthermore, men with CVD with frequent or complex arrhythmias had increased cardiac event rates and increased mortality compared to men without CVD (44). Recurrence of MI was closely related to transient atrial fibrillation, previous cerebrovascular accident and dyslipidemia (low ratio HDL-/LDL-cholesterol). All these findings indicate the significance of previous history of CVD on the risk of recurrent CVD.

Positive family history of coronary heart disease (CHD): A positive family history of $\mathrm{CHD}$ indicates that a person is at high risk of premature $\mathrm{CHD}$ independent of the presence of classical and non-classical risk factors (46). This observed familial disease aggregation is not well understood except for the general knowledge that genetic and environmental factors predisposing to CHD also aggregate in families (47). The Nijmegen Cohort Study found a risk ratio of 1.8 for CHD when a positive family history of premature CVD was present (36).

Smoking: Smoking has been associated with a two-to-fourfold increased risk of CHD, a greater than $70 \%$ excess rate of death from CHD, and an elevated risk of sudden death (49). These risks are aggravated in the presence of hypertension, hypercholesterolemia, glucose intolerance, and diabetes. Furthermore, smoking increases the risk of peripheral vascular disease (49). Two main components of cigarette smoking, nicotine and carbon monoxide, play major roles in endothelial injury and the development of atherosclerotic plaque (49).

Blood pressure and hypertension: High blood pressure, also called hypertension, increases the load on the heart, burdens the wall stress of the arteries, and accelerates cardiovascular degeneration and disease (50). Both systolic and diastolic blood pressures show a continuous, graded, independent relationship with risk of stroke and coronary events (34). Furthermore, the difference between systolic and diastolic blood pressure, i.e. pulse pressure, has been recognized as an independent predictor of carotid artery plaque ulceration (51), CVD and all cause mortality $(52,53)$. Historically, therapeutic intervention thresholds for treatment have been based on variable and somewhat arbitrary cut-off points. Risk factors of CVD are known to cluster in individuals and the definition of high blood pressure nowadays includes values that may be considered 'high' in high-risk subjects, but acceptable in individuals at lower risk (34).

Ankle/Brachial Index: The Ankle/Brachial pressure Index ( $\mathrm{ABI}$ ) is a commonly used non-invasive indicator of CVD (76) and is used to determine to whether peripheral vascular disease is present. In prospective epidemiological studies, a low ABI was associated with the extent of atherosclerosis in coronary and noncoronary arterial beds (76), an increased incidence of ischemic stroke (77), and was found to be an effective predictor of cardiovascular risk (25). Furthermore, it was associated with an increased risk of subsequent non-fatal cardiovascular events, independent of age, gender, and the presence of angina pectoris, myocardial infarction and diabetes at baseline (76). It reflects generalized atherosclerosis and improves predictions of future cardiovascular events based on conventional risk factors alone $(76,78)$. 
Microalbuminuria: It has been shown that increased urinary albumin and protein excretion rates precede, and therefore, predict cardiovascular mortality in subjects with and without type 2 diabetes $(79,80)$. An increased urinary albumin excretion rate is often associated with adverse changes in cardiovascular risk factors, and it may be a marker of widespread endothelial dysfunction or vascular damage, in the kidney or elsewhere, enhancing atherosclerosis.

Glucose concentration and type 2 diabetes: The prospective Cardiovascular Health Study found that $2 \mathrm{~h}$ post-load glucose level was better than fasting glucose level alone at identifying older adults at increased risk of major incident cardiovascular events (93). Furthermore, a metaregression analysis showed a continuous positive relationship between initial fasting and $2 \mathrm{~h}$ post-load glucose and CVD events that extended below the current thresholds for IGT $(6.1 \mathrm{mmol} / \mathrm{L})$ and IFG $(5.6 \mathrm{mmol} / \mathrm{L})(94)$. Moreover, the DECODE study showed that the relationship between fasting glucose and mortality was dependent of $2 \mathrm{~h}$ post-load glucose, but that the relationship of mortality with $2 \mathrm{~h}$ postload glucose was independent of fasting glucose (95). Adjustment for other CVD risk factors demonstrated a continuous relationship between $2 \mathrm{~h}$ post-load glucose and CHD, stroke, all CVD and all-cause mortality, but suggested a possible threshold effect with fasting glucose at $7.0 \mathrm{mmol} / \mathrm{L}$, i.e. the level at which type 2 diabetes is diagnosed. Type 2 diabetes increases the risk of CVD 2- to 4-fold compared to the risk in subjects without diabetes, and approximately $65 \%$ of all patients with type 2 diabetes die from $\mathrm{CHD}$ (57). Epidemiological and pathological data document that diabetes is an independent risk factor for several forms of CVD in both men and women (57). When CVD develops in patients with type 2 diabetes, they sustain a worse prognosis $6 r$ survival than do CVD patients without diabetes. More about the relationship between type 2 diabetes and CVD is described in section 1.5.

Total cholesterol, LDL- and HDL-cholesterol: Elevated total serum cholesterol strongly increases the long-term absolute risk of death in men with CHD (55). Furthermore, the incidence of definite coronary events increased when total cholesterol levels were elevated (47). LDL is the principal cholesterol-carrying lipoprotein and therefore plays a central role in atherosclerosis (56). An elevation of LDL-cholesterol is a major risk factor for CVD and was associated with an increase in CHD independent of the usual coronary risk factors such as smoking, blood pressure, total cholesterol, HDLcholesterol and diabetes (56-59). In fact, an elevation of LDL-cholesterol appears to be necessary for the initiation and progression of atherosclerosis (56). This has led to the lipoprotein retention theory (96), which is described in section 1.3. In contrast with this, reduction of $\mathrm{HDL}$-cholesterol levels results in the disappearance of the cardioprotective effect of HDL. This cardioprotective effect is attributed to the role of HDL-cholesterol in reverse cholesterol transport (97). In this reverse transport, cholesterol is accepted from peripheral tissues by small, dense HDL particles. When enough cholesterol is accepted, these particles become larger and less dense and can transfer cholesterol esters to apolipoprotein B100 or directly to the liver (97). It is known that HDL can remove colesterol from macrophages, thus preventing the formation of foam cells which are part of the development of an atherosclerotic lesion. Other mechanisms by which HDL inhibits atherosclerosis are prevention of oxidation of LDL and of adhesion of monocytes to the endothelium $(98,99)$.

Small, dense LDL particles: Krauss and Blanche (100) reviewed LDL structural heterogeneity and divided the LDL profile into two phenotypes, pattern A and B. In 
pattern A, large-sized LDL is dominant and in pattern B, a greater proportion of small, dense LDL exists. The presence of small, dense LDL is mostly associated with moderate elevation in plasma triglycerides, low levels of HDL-cholesterol, abdominal obesity, insulin resistance and other metabolic abnormalities predictive of impaired endothelial function and increased susceptibility to atherothrombosis (63). Small, dense LDL has been shown to be more readily oxidized than its larger counterparts. Because of its reduced size it is also more likely to penetrate the arterial wall. In addition, it was shown that small, dense LDL has an enhanced affinity for arterial wall proteoglycan, thus prolonging its residence time in the subendothelial space (63). All these features contribute to the enhanced atherogenicity of small, dense LDL particles and it has been shown that the presence of small, dense LDL particles was associated with more than a three-fold increase in the risk of $\mathrm{CHD}$ (63).

Apolipoprotein B: Apolipoprotein B (apoB) is an important risk factor of myocardial infarction (71) and was found to be a better predictor of CHD risk in adults and in children than total cholesterol, triglycerides, HDL-cholesterol and small, dense LDL (7175). Furthermore, apoB was a better predictor of risk than LDL in individuals with LDL concentrations below the median value (71). Several studies have suggested that apoB in atherogenic particles (mainly LDL, but also very-low-density lipoprotein (VLDL)) could improve the prediction of risk of CHD (72-74). Additionally, apoB might be predictive in subjects with insulin resistance or diabetes because their atherogenicity is mainly seen when lipid abnormalities, such as abnormal VLDL and intermediate density lipoprotein (IDL), and small, dense LDL and HDL particles, are present.

Triglycerides: A high level of triglycerides called hypertriglyceridemia reflects an increase in VLDL and IDL particles and is often found in the presence of small, dense LDL (73). Hokanson and Austin (65) reported that elevated triglycerides were associated with a $30 \%$ increase in cardiovascular risk in men and a $75 \%$ increase in women, independent of HDL-cholesterol and other risk factors. Furthermore, it is becoming more and more accepted that hypertriglyceridemia acts as a synergistic risk factor of CHD with other lipid risk factors such as high LDL-cholesterol and low HDLcholesterol (66). Moreover, hypertriglyceridemia is recognized as a marker among metabolic and clinical conditions that are associated with increased risk for atherosclerosis (65).

Insulin: Elevated fasting plasma insulin called hyperinsulinemia is one of the characteristics of the insulin resistant state. Hyperinsulinemia in nondiabetic men is associated with the greatest relative increase in the risk of $\mathrm{CHD}$ irrespective of the presence or absence of other lipoprotein abnormalities such as elevated apoB, elevated or presence of small, dense LDL, elevated triglycerides or reduced HDLcholesterol $(68,69)$. Hyperinsulinemia appears to have a direct effect on the arterial wall by changing endothelial cells that synthesize plasminogen activator inhibitor 1 (PAL1) (101). An increase in PAt1 can result in hypofibrinolysis which increases the risk of CVD. Furthermore, hyperinsulinemia is most frequently associated with deteriorations in other CVD risk factors. Clustering of hyperinsulinemia with other risk factors is called the metabolic syndrome, which is known to increase the risk of CVD (102). Isolated hyperinsulinemia however, has a low prevalence rate on its own, and currently, no absolute cut-off point exists to define hyperinsulinemia. Arbitrary cut off points are being used which are based on the upper normal limit of insulin or on a predefined percentile of the background population to indicate insulin resistance and hyperinsulinemia. More 
commonly used towever, is the homeostasis model assessment (HOMA) to estimate insulin resistance by the ratio of fasting glucose to insulin concentrations (102). This is a simple and inexpensive alternative for more sophisticated techniques such as the clamp technique (103).

C-reactive protein: C-reactive protein (CRP) is an acute phase protein because of the pronounced rise that is seen in its concentration after tissue injury or inflammation. It is produced in the liver and is primarily derived via interleukin-6 (IL-6)-dependent hepatic biosynthesis. IL -6 is an important adipocyte signalling molecule released from visceral and subcutaneous fat stores (104). CRP is also produced in small amounts by normal blood lymphocytes (105). Furthermore, it is known that CRP stimulates soluble intercellular cell adhesion molecule 1 (sICAM-1) (105), a suggested marker of endothelial dysfunction (106). CRP can be seen as an inflammatory biomarker and has proven to be a strong independent predictor of incident CVD (81) and of future cardiovascular risk in both men and women (22,82). CRP regulates endothelial nitric oxide synthase expression and nitric oxide synthesis and upregulates the expression of cellular adhesion molecules. It may also directly modulate the oxidation of LDL (81). Furthermore, smooth muscle cells and macrophages in arterial tissue have been shown to produce CRP, a process that is substantially upregulated in the atherosclerotic plaque (22). Elevated CRP levels may be a marker of the hyper-responsiveness of the inflammatory system even to small stimuli (82). CRP was shown to be a stronger predictor of future CVD events than LDL and can identify at-risk individuals with low LDL levels $(81,82)$.

Homocysteine: Increased levels of homocysteine, also called hyperhomocysteinaemia, is an independent risk factor for CVD and all-cause mortality (85). In addition, high levels increase the risk of fatal and non-fatal coronary events (86). Some studies found an association between hyperhomocysteinaemia and intima-media thickness (87-90), a surrogate marker of atherosclerosis, but other studies failed to show such associations $(90,91)$. Furthermore, hyperhomocysteinaemia is associated with impairment of endothelial regulatory functions, characterised by decreased nitric oxide synthesis or availability, and prothrombotic changes (92). It is unclear however whether homocysteine itself is causal in the pathogenesis of CVD, nor has it been fully elucidated yet by which mechanism(s) hyperhomocysteinaemia exerts its adverse effects on the vascular wall.

\subsection{2: Risk assessment scores}

Risk factors by itself and in combination with each other can be used in the risk assessment of CVD, and risk assessment as well as risk factor modification has become essential tools in the management of CVD (107). Among the first to develop a risk assessment score were the researchers of the Framingham Heart Study. The Framingham risk score can be used by physicians to assess the cardiovascular risk of individuals. The Framingham risk score is based on age, gender, total, HDL-, and LDLcholesterol, smoking, presence of diabetes and blood pressure (107). Other studies that have developed risk scores for the assessment of cardiovascular risk include the Systematic Coronary Risk Evaluation (SCORE) project (108), the PRECARD® study (109), the Prospective Cardiovascular Munster Study (PROCAM) (110) and the UKPDS study (111). 
SCORE: The SCORE risk assessment system is derived from a large dataset of prospective European studies and predicts any kind of fatal atherosclerotic end-point, such as fatal CVD events, over a 10-year period (108). Variables included in the SCORE project are age, gender, total cholesterol, systolic blood pressure and smoking. Different charts are developed for European regions at high risk and a low risk for CVD. However, glucose tolerance is not a risk factor that is included in the SCORE risk function which makes the risk assessment inappropriate for subjects with diabetes. Therefore, the European Society of Cardiology has recommended that subjects with diabetes are considered as subjects with "established CVD" and need to change lifestyle when relevant, receive aspirin and a statin, and consider hypertension treatment (26). Subjects without diabetes need to have their risk score assessed before therapy is implicated or existing therapy is adjusted.

PRECARD®: The PRECARD® study is a European risk calculation program developed in Denmark which calculates the absolute and relative risks for coronary heart disease as well as the expected efficacy of any intervention (109). The PRECARD® program uses the Copenhagen Risk Score to calculate absolute risk for coronary heart disease and generates an individualized patient-focused health advice. It is based on nonmodifiable and modifiable risk factors, i.e. age, gender, presence of diabetes, genetic predisposition, previous coronary heart disease, and smoking, total cholesterol, HDLcholesterol, body mass index, systolic blood pressure.

PROCAM: The PROCAM study is a prospective study for cardiovascular isk factors (110). Their scoring scheme was based on the follow-up results of middle-aged men in Germany and included the variables age, LDL-cholesterol, smoking, HDL-cholesterol, systolic blood pressure, family history of premature myocardial infarction, presence of diabetes mellitus, and triglycerides (www.chd-taskforce.com). The risk however cannot be extrapolated to women.

UKPDS Risk Engine: A diabetes-specific risk engine was recently created by the UK Prospective Diabetes Study (UKPDS) team, including the variables age, sex, ethnicity, smoking status, presence or absence of atrial fibrillation and levels of $\mathrm{HbA} 1 \mathrm{c}$, systolic blood pressure, total cholesterol and HDL-cholesterol (111). This risk engine is developed specifically for calculating the risk of CHD in ten years in individuals with type 2 diabetes not known to have a heart disease (www.dtu.ox.ac.uk/index.html?maindoc=riskengine).

When comparing the different risk scores, very different percentages are calculated. For example, a Caucasian non-smoking male of 60.7 years of age, with a type 2 diabetes duration of 1 year, with $\mathrm{HbA} 1 \mathrm{c} 6.9 \%$, systolic blood pressure $147 \mathrm{mmHg}$, total cholesterol $5.2 \mathrm{mmol} / / \mathrm{l}(198 \mathrm{mg} / \mathrm{dl})$, HDL-cholesterol $1.0 \mathrm{mmol} / \mathrm{l}(38 \mathrm{mg} / \mathrm{dl})$, LDLcholesterol $3.1 \mathrm{mmol} / \mathrm{l}(118 \mathrm{mg} / \mathrm{dl})$, triglycerides $1.8 \mathrm{mmol} / \mathrm{l}(178 \mathrm{mg} / \mathrm{dl})$, no previous history of $\mathrm{CHD}$ and no family history of $\mathrm{CHD}$, has a $22.8 \%$ risk of $\mathrm{CHD}$ in 10 years according to the UKPDS Risk Engine, 18\% risk of acute coronary events in 10 years according to the PROCAM risk score and only $5 \%$ risk of CVD in 10 years according to the SCORE risk for populations at high risk. More research is therefore needed considering the applicability of the these risk scores in different populations.

The contribution of risk factors to the risk of developing cardiovascular disease is not fully known yet, but recently it was shown that $80 \%$ to $90 \%$ of patients who developed clinically significant $\mathrm{CHD}$, and more than $95 \%$ of patients who experienced a fatal CHD event, had at least one of the conventional risk factors, i.e. cigarette smoking. 
diabetes, hyperlipidemia, or hypertension (112,113). In addition, a literature study about 4 emerging, non-classical risk factors, i.e. Creactive protein, lipoprotein(a), fibrinogen and homocysteine, could not determine what their optimal use was in routine screening and risk stratification of CVD (114). These reports challenge the frequent claim that only $50 \%$ of $\mathrm{CHD}$ is attributable to the conventional risk factors of smoking, diabetes, hypertension and hyperlipidemia and point out that additional research is needed to establish the role of other novel CVD risk markers.

\section{3: Atherosclerosis}

The lesions of atherosclerosis principally occur in large and medium-sized elastic and muscular arteries and may be present throughout a person's lifetime in a relatively benign form (115). The earliest type of atherosclerotic lesion, the so-called fatty streak, is commonly present in infants and young children (116). However, these lesions can also result in ischemia of the heart, brain, or extremities, resulting in infarction. It is not yet clear which process is the key event in the initiation and development of early atherosclerosis. Presently, two hypothesis about the early processes of atherosclerosis exist, namely the 'response-to-injury' hypothesis and the 'response-to-retention' hypothesis. The response-to-injury hypothesis states that atherosclerosis is a process of endothelial injury or activation (117-120), and recently, of inflammation (115). In this hypothesis, hyperlipidemia, endothelial dysfunction and permeability, blood flow, and lipoprotein oxidation are thought to be causes of the early atherosclerosis process. Williams and Tabas disagreed with the response-to-injury hypothesis and modified it to the response-to-retention hypothesis (96). This theory states that lipid retention in the arterial wall is the key pathogenic event that is necessary for the formation of an atherosclerotic lesion in an otherwise-normal artery, and that hyperlipidemia, lipoprotein modification, turbulent blood flow and alterations in endothelium, smooth muscle cells and the matrix only contribute to the atherosclerosis process (Figure 2).

After the formation of an early atherosclerotic lesion, accumulation of mononuclear cells, migration and proliferation of smooth muscle cells, and formation of foam cells and fibrous tissue takes place (115). This will lead to further enlargement and restructuring of the lesion, so that it becomes covered by a fibrous cap that overlies a core of lipid and necrotic tissue, a so-called advanced, complicated lesion (97). The artery wall thickens, which is compensated by gradual dilation, so that the lumen remains unaltered (121). This process is also known as arterial remodelling. At some point, the artery can no longer compensate and the lesion may than intrude into the lumen and alter the blood flow. In most patients, myocardial infarction results of erosion or uneven thinning of the fibrous cap with subsequent rupture, often at the shoulders of the lesion where the macrophages enter, accumulate, and are activated (122). The continuing influx and activation of macrophages results in release of metalloproteinases and other proteolytic enzymes. These enzymes cause degradation of the matrix, which can lead to haemorrhage from the vasa vasorum or from the lumen of the artery and can result in thrombus formation and occlusion of the artery. 


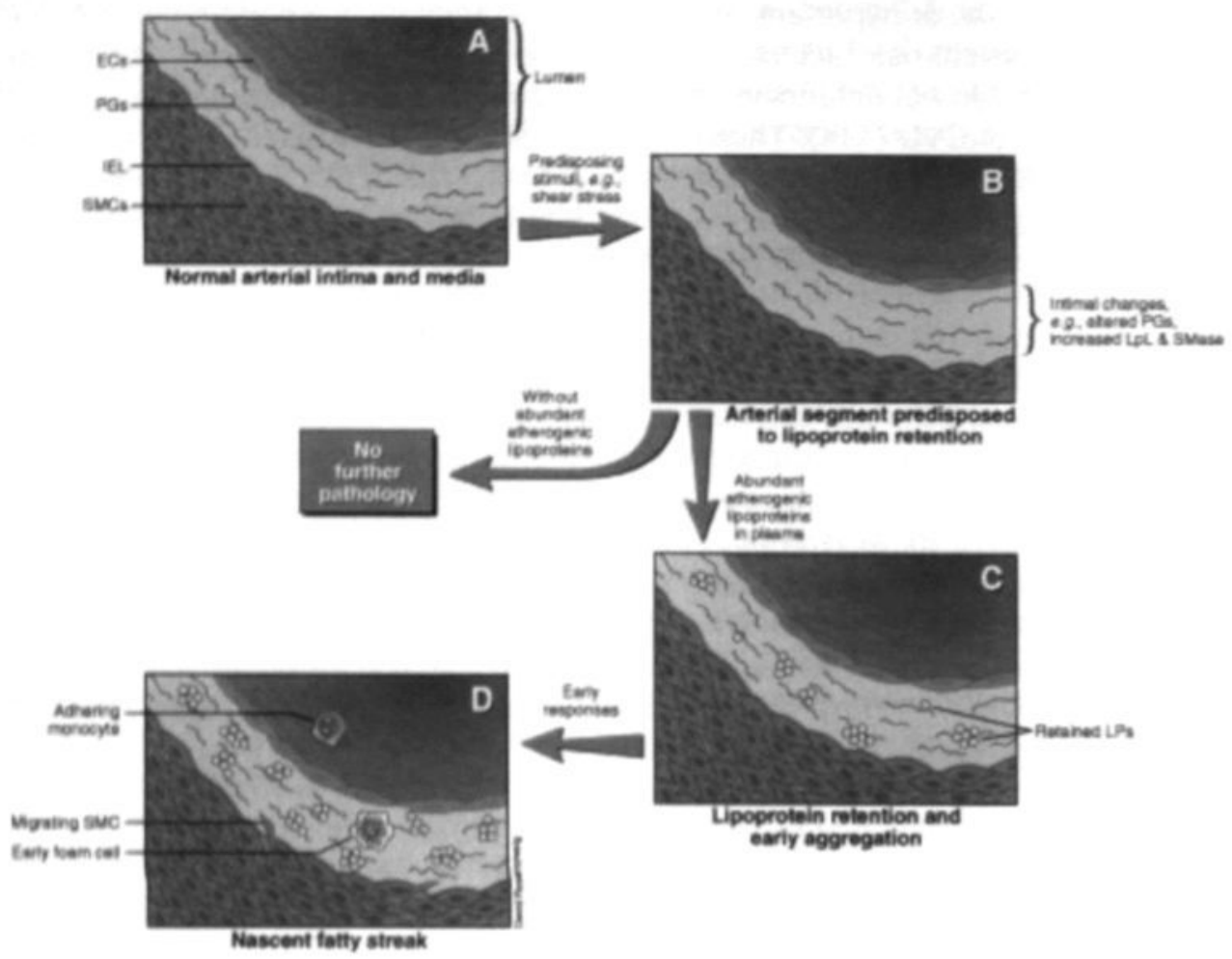

Figure 2 Schematic of the responseto-retention model of early atherosclerosis. Mild to moderate hyperlipidemia causes lesion development only in specific sites within the arterial tree, implying the existence of predisposing stimuli, such as shear stress, that make these sites particularly lesion-prone by stimulating local synthesis of apoB-retentive molecules (B). Predisposing stimuli in the absence of abundant atherogenic lipoproteins (i.e. $<2 \mathrm{mmol}$ LDL cholesterol/L) are insufficient to cause atherosclerosis. Predisposing stimuli in the presence of abundant atherogenic lipoproteins result in lipoprotein retention (C). Evidence suggests that aggregation promptly follows or may be part of the retentive process. Once significant retention has occurred, a cascade of early responses, including lipoprotein oxidation and cellular chemotaxis, leads to lesion development (D). ECs indicate endothelial cells; PGs proteoglycans; IEL internal elastic lamina; SMCs smooth muscle cells; LpL lipoprotein lipase; SMase sphingomyelinase; LPs lipoproteins (96).

\subsection{1: Plaque vulnerability}

Three major factors determine the vulnerability of the fibrous cap: circumferential wall stress or cap 'fatigue', lesion characteristics (location, size, and consistency), and blood flow characteristics (123). A plaque is considered vulnerable when the lipid core accounts for more than $40 \%$ of the whole core (123). This may explain the beneficial effects of lipid-lowering therapy in reducing coronary events. It is of interest that the culprit lesions leading to acute coronary syndromes are often mildly stenotic and are therefore, as a rule, not detectible by angiography (123). These rupture-prone lesions usually have a large lipid core, a thin fibrous cap, and a high density of inflammatory cells, particularly at the shoulder region. Furthermore, one third of acute coronary syndromes occur without plaque disruption but in plaques with a superficial erosion 
(123). Thrombus formation depends under such conditions on the prothrombogenic state triggered by systemic factors, such as elevated LDL and decreased HDLcholesterol, cigarette smoking, diabetes, and yet unidentified factors.

\subsection{2: Role of endothelial dysfunction and permeability in early atherosclerosis}

Endothelial injuries are thought to play a key role in early atherogenesis in the response-to-injury hypothesis if they are severe enough to cause functional modifications $(117-120,124)$ such as increased permeability, particularly to atherogenic lipoproteins $(125,126)$. Possible causes of endothelial dysfunction in the injury theory include 1) elevated and modified LDL; 2) free radicals caused by cigarette smoking. hypertension, and diabetes mellitus; 3) genetic alterations; 4) elevated plasma homocysteine concentrations, 5) infectious micro-organisms such as herpesvirus, and 6) combinations of these or other factors (53). However, research showed that normal, healthy endothelium transports, or 'leaks' many molecules, including lipoproteins, and that the rate of LDL transport into the normal, healthy arterial wall exceeds the LDL accumulation rate (96). Most importantly, several studies showed in vivo that the rates of lipoprotein entry into prelesional susceptible sites, i.e. sites of low shear stress such as non-branch points, were not different from resistant sites for the development of atheromata, i.e. sites of high shear stress. Therefore, Williams and Tabas stated that enhanced endothelial permeability to lipoprotein influx appears not to be the key pathological event in atherosclerosis (96). However, because prelesional susceptible arterial sites show enhanced retention of apoB-rich atherogenic lipoproteins, Williams and Tabas argued that endothelial permeability can play a contributory role in conditions such as smoking, dyslipidemia, and hypertension, but only if some of the infiltrated material is retained (96). Retention of lipoproteins may be caused by advanced glycosylation end-products (AGEs) which are shown to trap soluble plasma proteins (127). Covalent trapping of low-density lipoproteins by AGE on collagen may promote excessive lipid accumulation in the arterial walls of diabetics. Furthermore, LDL particles isolated from patients with CHD have higher affinity for proteoglycans glycosaminoglycans in the vessel wall than LDL from control patients $(128,129)$.

\subsection{3: Role of cell adhesion molecules in early atherosclerosis}

Other functional modifications that have been documented in the endothelial layer in vivo during the atherosclerotic process are the expression of cell adhesion molecules by endothelial cells that overlie lesions, such as vascular adhesion molecule-1 (VCAM1) (96). However, this seems to be a consequence of initial retention of lipoproteins within the arterial wall rather than a cause of endothelial changes, because expression of cell adhesion molecules was shown after more than four days of severe hypercholesterolemia and resultant foam cell formation, while lipoprotein retention and aggregation was detectable within minutes to hours after the onset of hypercholesterolemia (96). Furthermore, it was shown that atherogenic lipoproteins regulate the endothelial expression of cell adhesion molecules (96). 


\subsection{4: Role of blood flow in early atherosclerosis}

Turbulent blood flow also may have an early effect on atherosclerosis (96). However, lesion development at sites of turbulent flow in vivo show an absolute requirement of high plasma concentrations of atherogenic lipoproteins. The plasma concentration of LDL must exceed $2 \mathrm{mmol} / \mathrm{L}$ for atherogenesis, even at sites of high shear stress such as at branch points (96). Furthermore, at sufficiently high plasma concentrations of lipoproteins, lesions develop at sites of low shear stress, such as at non-branch points. Williams and Tabas hypothesized that the role of shear stress in early atherogenesis is primarily through the stimulation of intramural synthesis of molecules, such as proteoglycans, that promote lipoprotein retention (96). Later, once retained lipoproteins are accumulated within the arterial wall, the threshold for injury and activation from continued shear stress may be lowered. Because many stimuli are known to activate endothelial cells, synergy is likely between shear stress and, for example, oxidative breakdown products of retained lipoproteins.

\subsection{5: Lipoprotein oxidation in early atherosclerosis}

In the response-to-injury hypothesis, lipoprotein oxidation plays an important role (130132). However, in vitro lipoprotein oxidation by cells or transition metal is blocked by low concentrations of plasma or plasma proteins such as albumin, and in vivo oxidized lipoproteins in the plasma would be rapidly removed by the liver. Furthermore, it was shown that adherence of LDL to arterial proteoglycans increased LDL's susceptibility to oxidation in vitro, but that prior oxidation of LDL does not enhance its retention in arteries (96). Moreover, once lipoproteins are sequestered from the protective elements of plasma in vitro, nearby healthy arterial cells will cause oxidation (96). Therefore, oxidation can be seen as a normal, expected consequence of intramural sequestration of sufficient quantities of atherogenic lipoproteins within an otherwise healthy artery. Therefore, Williams and Tabas think that pathophysiologically important oxidation can occur only after the retention of lipoproteins within the microenvironment of the arterial wall (96).

Although factors responsible for retention of lipoproteins and subsequent lesion development are not clear yet, it is known that, after retention by proteoglycans in the arterial wall, LDL undergoes several modifications with important biological consequences (96). Retained and modified lipoproteins and nearby macrophages can stimulate chemotaxis and transformation of smooth muscle cells from the contractile to the proliferative state (115). This causes increased synthesis of proteoglycans in smooth muscle cells, including LDL-binding proteoglycans which may result in an increased retention of lipoproteins. In vitro, proteoglycan-bound LDL forms aggregates and vesicular structures and shows increased susceptibility to oxidation. Minimally oxidized LDL induces endothelial and smooth muscle cells to express monocyte chemotactic activity, and more extensively oxidized LDL is directly chemoattractive to monocytes, macrophages, smooth muscle cells, and T-lymphocytes $(96,116)$. Recently, a report showed that lipid retention in the vascular wall of two mouse strains with different atherosclerosis susceptibility is not sufficient to promote progression to an atherosclerotic plaque after the first lesion has formed, but points to the more important role of endothelial cells in this regard (133). The conversion of macrophages to foam 
cells stimulates the release of more lipoprotein lipase and other atherogenic factors. Also, it has been shown to alter proteoglycan metabolism which may result in more lipid retention.

\subsection{6: Conclusion}

Atherosclerosis is a complex and multifactorial process. Today, two theories exist about the early process of atherosclerosis, i.e. the response-to-injury hypothesis and the response-to-retention hypothesis. Both theories have their merit. Recent findings favour the response-to-retention hypothesis for its role in the process which results in the formation of an early atherosclerotic lesion. Factors such as hyperlipidemia, smoking. hypertension, turbulent blood flow and lipoprotein oxidation can increase the harmful effects of lipid retention in the arterial wall and contribute to the development of an atherosclerotic lesion into an atherosclerotic plaque. The response-to-injury hypothesis may be more appropriate to describe the development to an unstable vulnerable plaque. After the first formation of an atherosclerotic lesion, foam cells and fibrous tissue are formed, which leads to enlargement of the lesion. This will eventually result in intrusion of the atherosclerotic plaque in the vascular lumen. Different factors determine the vulnerability of the plaque, and when thinning of the fibrous cap occurs, rupture of the plaque can take place. This can result in thrombus formation and occlusion of the artery leading to myocardial infarction or stroke.

\section{4: Surrogate markers for atherosclerosis}

The atherosclerosis process is slow and often remains 'silent' until the first clinical manifestation presents itself. Frequently, this first manifestation is a major cardiovascular event such as myocardial infarction, stroke, or sudden death (134). Epidemiological studies and intervention trials with such clinical endpoints require long time follow-up and participation of large populations. These studies are, by necessity, costly and long-term. There is however an urgent need for data from which valid conclusions can be drawn about the determinants of the disease or the effectiveness and safety of a therapeutic intervention (135). Therefore, surrogate markers are continuously sought, which can be used to investigate determinants of atherosclerosis at early stages of the process. Also, at a later stage, they can be used to assess disease modifiers of atherosclerosis progression, such as lifestyle and pharmacological interventions.

\subsection{1: Intima-media thickness}

Early surrogate markers for atherosclerosis have riginated from techniques available for the clinical assessment of patients with vascular disease, such as angiography and Doppler ultrasound. However, these techniques do not provide useful information on the early stages of arterial wall thickening prior to lesion formation $(121,136,137)$. In contrast, ultrasound techniques have evolved to such extent that the walls of superficial arteries can be imaged non-invasively in real-time and at high resolution. Ultrasound imaging can visualize the arterial wall tself in every stage of atherosclerosis, from a 
normal lumen to a plaque or complete arterial occlusion. The distance between the ultrasound interfaces of the lumen-intima and media-adventitia ultrasound on the far wall have been proven to reflect the intima-media complex by histological and pathological studies (138-140) and is widely known as intima-media thickness or IMT. Because ultrasound imaging is non-invasive, IMT measurements can be used in observational studies in healthy populations as well as in trials on atherosclerosis progression.

IMT can be measured at the femoral and brachial arteries, but is mostly measured at the carotid artery. Different segments of the carotid artery can be used for IMT measurements, i.e. common carotid artery, bulbus and internal carotid artery (Figure 3), but reproducibility is higher in the common carotid artery segment (141). Atherosclerosis in the carotid arteries is correlated with coronary artery calcium detected on electron beam CT scans, which is a marker of atherosclerotic disease (142). Furthermore, larger IMT of the carotid artery has been shown to be associated with elevated levels of risk factors for coronary heart disease (CHD) in a number of prospective studies (134), as well as in numerous population- and hospital-based studies (143-146). In addition, the relationship between carotid IMT and future CHD events have been confirmed many times (147-152). Furthermore, it has been shown that lipid-lowering treatment can slow the progression rate of carotid IMT $(134,153)$. Therefore, IMT can be considered a marker of change in atherosclerosis elsewhere in the arterial system and should reflect generalized vascular damage or atherosclerosis as a surrogate marker, and thus cardiovascular risk.

The majority of cross-sectional studies indicated that elevated levels of established risk factors of CVD such as age, sex, total cholesterol, LDL-cholesterol, systolic blood pressure, body mass index (BMI), and a decrease in HDL-cholesterol are associated with an increased carotid IMT in a graded manner (154). In addition, subjects with a certain lifestyle or predisposing condition, such as smoking, hypertension, diabetes mellitus, previous $\mathrm{CHD}$ or intermittent claudication, have a 5 to $12 \%$ increased carotid IMT relative to subjects without these conditions (154). Moreover, Greactive protein has been associated with increased carotid IMT which indicates the potential of C-reactive protein as a risk factor for CVD $(155,156)$.

A variety of IMT measurement protocols, based on different ultrasound methods, have been developed and improved in order to obtain reliable and reproducible results (137-142,157). Both B- and M-mode ultrasonographic techniques are used to measure IMT and there is an acceptable agreement with no important systematic difference between these two methods (158). With the B-mode technique, proposed by Bond and Ball (159), Pignoli et al. (136) and further developed by Wendelhag et al. (140), a twodimensional ultrasound image is made of the carotid artery, and the anterior wall, lumen and posterior wall can be distinguished (150). Another technique, using M-mode images, has been proposed by Roman et al. (160). Two-dimensionally guided M-mode tracings of the common carotid artery are performed and stored for off-line analysis. The B-mode technique represents the average IMT of an arterial segment whereas Mmode IMT is the IMT at a discrete arterial position. Most research has been published using the B-mode technique, because it was the first ultrasound technique developed to image the vascular wall. However, the $\mathrm{M}$-mode technique is more time efficient than the B-mode, is more user-independent, and has an adequate reproducibility (157). In addition, with the $\mathrm{M}$-mode technique it is easier to assess local pulse pressure, wall 
thickness, diameter and distensibility (relative increase in cross-sectional area per change in blood pressure) (157). These parameters can be used to calculate vascular characteristics such as the distensibility and compliance coefficient and Young's elastic modulus (50). The reproducibility of these arterial stiffness measurements has been sufficiently studied to be applied in epidemiological studies $(161,162)$, and can be used to non-invasively study early functional and structural wall changes caused by atherosclerosis. Distensibility is the ability of the artery to expand as a response to pulse pressure, i.e. the relative change in arterial diameter during the cardiac cycle, and distensibility decreases with age and hypertension (50). Compliance is defined as the ratio of change of volume to change in pressure, or the slope of the pressure volume curve, and is related to the distensibility and diameter of the artery. Young's elastic modulus provides information on the mechanical properties of the wall material independent of the geometry $(50)$ and can be considered a marker of arterial stiffness. Formulas to calculate these parameters are given in Chapter 5.

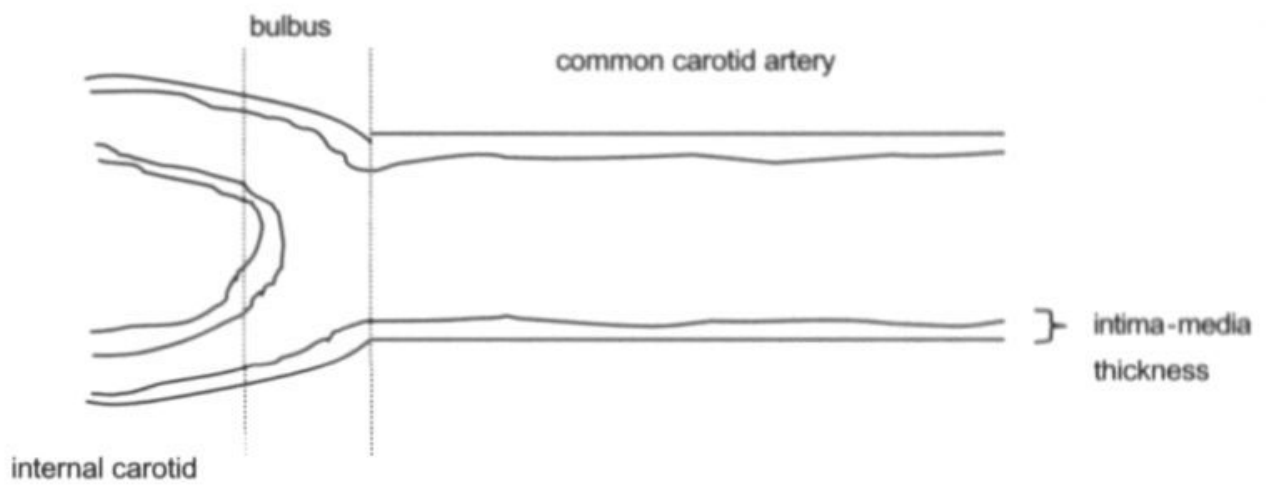

artery

Figure 3: Illustration of the carotid artery with intima-media thickness and the 3 segments division, based on the arterial anatomy and geometry. The 3 segments are the distal common carotid artery, the carotid bifurcation or bulbus, and the proximal internal carotid artery.

\subsection{2: Arterial stiffness}

Arterial stiffness relates to the cushioning function of the arteries and is determined by the visco-elastic properties of the artery wall (147). These properties are determined by smooth muscles cells and the elastin to collagen ratio, whereas the subendothelial matrix also affects arterial stiffness. One of the clearest consequences of increased arterial stiffness of the large arteries is increased pulsatile blood pressure. Increased pulse pressure leads to an increased left ventricular workload in combination with a reduced perfusion of the coronary arteries in diastole (50). However, the pathophysiological mechanisms of stiffening of the arteries are not fully understood. The most prominent factor is age: with increasing age, arteries become stiffer (50). With ageing, the increase in large artery stiffness is related to the degree of mechanical stress that results in fragmentation and disruption of elastic lamellae and in 
derangement of the orderly structure of the elastic laminae of the vessel wall, changing the collagen to elastin ratio (50). Furthermore, sustained hypertension can result in accelerated arterial degeneration and to prematurely occurring structural changes similar to those seen in ageing. Other causes of altered structural arterial wall properties may be plaques (163) or hemodynamic factors (164). Moreover, structural changes can be caused by formation of advanced glycosylation end products (AGEs), secondary to hyperglycemia in diabetes or IGT subjects (165). AGEs induce collagen cross-linking due to non-enzymatic glycation of arterial wall matrix proteins and can trap atherogenic lipoproteins as well $(128,166)$. The endothelial stress caused by the actions of AGEs may induce secretion of specific proteins that will be deposited in the matrix $(167,168)$ and this process may lead to structural changes and remodelling (169). In addition to the above mentioned factors, smoking, elevated lipid levels, and indicators of glucose intolerance were also found to be related to arterial stiffness $(161,162,170,171)$.

Arterial stiffness can be assessed using ultrasound as was described in section 1.4.1. Stiffness measured by this method is local and of superficial arteries. Another non-invasive method to measure arterial stiffness is the aortic pulse wave velocity technique, although this technique does not measure local but regional or segmental arterial stiffness. The aortic pulse wave velocity can also be measured by the wall tracking system, and is calculated from measurements of pulse transit time and the distance travelled by the pulse between the common carotid artery and one of the common femoral arteries (172). The propagation speed of the pulse wave along the arteries is related to the elastic properties of the arterial wall and depends on current distending blood pressure. Arterial stiffness measurements described in this thesis are all done by means of $\mathrm{M}$-mode ultrasound imaging wall track techniques.

\subsection{3: Prospective studies}

Several prospective cohort studies have examined the relationship between carotid IMT and CHD events (Table 2). In the Kuopio Ischemic Heart Disease (KIHD) risk factor study (151), it was found that for every $0.1 \mathrm{~mm}$ increase in carotid IMT in middle-aged men, the risk of myocardial infarction (MI) increased by $11 \%$. Similar results were found for this age group in the Atherosclerosis Risk In Communities (ARIC) study (148). In this study, a $0.19 \mathrm{~mm}$ increment in mean carotid IMT increased the risk of MI or coronary death in middle-aged men by $36 \%$ (Table 2). CHD risk was almost twofold higher in those men with a carotid IMT of $\geq 1.0 \mathrm{~mm}$ compared with a carotid IMT $<1.0$ $\mathrm{mm}$ (OR $1.85 ; \mathrm{Cl}: 1.28-2.69)$. In women, the incidence of $\mathrm{MI}$ or coronary death increased by $69 \%$ for every $0.19 \mathrm{~mm}$ increase in carotid IMT (Table 2). A mean carotid IMT of $\geq 1.0 \mathrm{~mm}$ was associated with a fivefold increase in CHD risk (OR 5.07; Cl: 3.08-8.36). In the Cardiovascular Health Study (CHS) (152), the relative risk of $\mathrm{MI}$ or stroke increased for every $0.2 \mathrm{~mm}$ increase in carotid IMT (Table 2), and the relative risk of $\mathrm{MI}$ increased by $46 \%$. Subjects in the highest quintile of carotid IMT had an almost fourfold increase in risk compared with subjects in the lowest quintile (OR 4.22; Cl: $3.02-5.91$ ). Similarly, in the Rotterdam Study (149), the risk of $\mathrm{MI}$ increased by $43 \%$ for every $0.16 \mathrm{~mm}$ increase in carotid IMT of the common carotid artery (Table 2). Following exclusion of subjects with a history of $\mathrm{MI}$ or stroke, a $0.16 \mathrm{~mm}$ increment in carotid IMT was associated with a $51 \%$ increase in the risk of MI (Table 2). However, in contrast with ARIC, the strength of the association between carotid IMT and the 
incidence of coronary events was similar in men and women. In a long-term follow up of male CHD patients who participated in the Cholesterol Lowering Atherosclerosis Study (CLAS) (150), the risk of MI or coronary death increased by $40 \%$ for every $0.13 \mathrm{~mm}$ increment in carotid IMT (Table 2) and the risk was almost eightfold increased in the highest quartile of carotid IMT relative to the lowest quartile (OR $7.7 ; \mathrm{CI}: 1.7-34.7$ ). Furthermore, for every $0.03 \mathrm{~mm} / \mathrm{y}$ increase in carotid IMT progression over the followup period, the risk of $\mathrm{MI}$ or coronary death doubled (OR 2.2; $\mathrm{Cl}$ : 1.4-3.6) whereas the risk of MI, coronary death or revascularisation tripled (OR 3.1: Cl: 2.1-4.5).

Longitudinal prospective data on the relation of arterial stiffness, measured by ultrasound, with future CVD are limited (147). Only three studies have been published in which common carotid distensibility measured by ultrasound imaging was used as marker for arterial stiffness (173-175). One of these studies also used Young's elastic modulus (175), an index of arterial stiffness, and was found to be an even stronger predictor for future CVD than distensibility or diameter. In subjects after renal transplantation, the distensibility of the common carotid artery was an independent predictor of CVD (174). In end-stage renal disease (ESRD) patients, Young's elastic modulus was associated with a 6.4 fold $(\mathrm{Cl}$ 1.8-23.3) increased risk of all-cause mortality, independent of other prognostic factors (175). Only one study has been published in subjects with impaired glucose tolerance (175). In this study, the distensibility coefficient appeared not to be related to increased mortality. Common carotid artery diameter however, was independently associated with mortality risk and most likely reflects arterial remodelling.

In summary, prospective studies on the potential relationships between carotid IMT and CHD events have been done in a variety of populations, healthy and symptomatic, and across various geographical areas (Table 2). These studies unequivocally show that IMT increments of $0.1 \mathrm{~mm}$ are associated with an increased odds ratio of various cardiovascular events in the range of 1.06 to 1.80 over a follow up period of 1 month to 8.8 years. However, only one prospective study (150) related change in carotid IMT over time to subsequent events. Therefore, more longitudinal data are needed on the change of carotid IMT as a predictor of CHD events. In contrast with carotid IMT, information $\boldsymbol{c}$ the relation of arterial stiffness and the risk of CVD among a large number of high-risk patients or among the general population is still lacking. Furthermore, direct comparisons between carotid IMT and indicators of arterial stiffness in their ability to predict future CVD has not yet been done. Both measurements however appear to be a useful as indicators of CVD risk although more data are needed to potentially distinguish subjects into those with a high and a low absolute risk of CVD. 


\begin{tabular}{|c|c|c|c|c|c|c|c|c|c|c|}
\hline Sudy & $\begin{array}{l}\text { Carotid IMT } \\
\text { measuremerts }\end{array}$ & $\begin{array}{l}\text { Clinical events } \\
\text { associated with } \\
\text { carctid IMT }\end{array}$ & $\begin{array}{l}\text { Folllow } \\
\text { up } \\
\text { perriod } \\
\text { (y) }\end{array}$ & $\begin{array}{l}\text { Age } \\
(y)\end{array}$ & $\begin{array}{l}\text { History } \\
\text { of CHD }\end{array}$ & Gender & $\begin{array}{l}\text { IMT }(\mathrm{mm}) \text { at } \\
\text { start of study }\end{array}$ & $\begin{array}{l}\text { Carotid } \\
\text { IMT } \\
\text { increme } \\
\text { rt (mm) }\end{array}$ & $\begin{array}{l}\text { Odds ratio } \\
\text { (CI) }\end{array}$ & \\
\hline KIHD (151) & $\begin{array}{l}\text { CCA and } \\
\text { carotid } \\
\text { bifurcation " }\end{array}$ & $\begin{array}{l}\text { Fatal, non-fatal } \\
\text { MI }\end{array}$ & $1 \mathrm{~m}-3 y$ & $42-60$ & - & Men & - & 0.10 & $\begin{array}{l}1.11(1.06 \\
1.16)\end{array}$ & - \\
\hline ARIC (148) & $\begin{array}{l}\text { CCA, internal } \\
\text { carotid arneries } \\
\text { and carotid } \\
\text { bifurcation" }\end{array}$ & $\begin{array}{l}\text { MI, coronary } \\
\text { death }\end{array}$ & 47 & $45-64$ & - & $\begin{array}{l}\text { Men } \\
\text { Women }\end{array}$ & $\begin{array}{l}0.76(0.76 \\
0.77)^{2} \\
0.68(0.68 \\
0.68)^{d}\end{array}$ & $\begin{array}{l}0.19 \\
0.19\end{array}$ & $\begin{array}{l}1.36(1.23 \\
1.51) \\
1.69(1.50 \\
1.90)\end{array}$ & - \\
\hline CHS (152) & $\begin{array}{l}\text { CCA and } \\
\text { internal carotid } \\
\text { arteries }\end{array}$ & MI, stroke & 6.2 & 265 & - & $\begin{array}{l}\text { Men } \\
\text { and } \\
\text { women }\end{array}$ & $1.03 \pm 0.20$ & 0.20 & $\begin{array}{l}1.46(1.33 \\
1.60)^{4}\end{array}$ & - \\
\hline $\begin{array}{l}\text { The } \\
\text { Rotterdam } \\
\text { Sudy (149) }\end{array}$ & $\mathrm{CCA}^{\circ}$ & MI & 2.7 & 255 & + & $\begin{array}{l}\text { Both } \\
\text { Both }\end{array}$ & $\begin{array}{l}0.86 \pm 0.19^{f} \\
0.80 \pm 0.15\end{array}$ & $\begin{array}{l}0.16 \\
0.16\end{array}$ & $\begin{array}{l}1.43(1.16 \\
1.78) \\
1.51(1.18 \\
1.78)\end{array}$ & - \\
\hline $\begin{array}{l}\text { CLAS } \\
\text { follow-up } \\
\text { study (150) }\end{array}$ & $\mathrm{CCA}^{\circ}$ & $\begin{array}{l}\text { Coronary death, } \\
\text { non-fatal MI, } \\
\text { coronary } \\
\text { revascularisatio } \\
\text { n, CABG } \\
\text { surgery }\end{array}$ & 8.8 & $40-59$ & + & Men & $0.66 \pm 0.14$ & 0.13 & $\begin{array}{l}1.40(1.10 \\
1.80)\end{array}$ & - \\
\hline
\end{tabular}

- Adapted from Bots and Grobbee. 2002 (134).

Mean carotid IMT.

"Mean IMT with $95 \%$ confidence interval of subjects with no CHD event affer follow up, subjects with CHD events after follow up had mean IMT women $0.83(0.79-0.86)$ men $0.84(0.82-0.86)$

"Mean of common carotid artenes and internal carottid arteries combined.

- The odds ratio stated is for risk of myocardial infarction (MI) only. The odds ratio for MI and stroke was 1.47 (1.37-1.57)

'Common carotid arteries IMT.

'Mean common carotid artery.

"Baseline IMT of subjects with MI after follow up. Barseline IMT of subjects with stroke ater follow up was $0.91 \pm 0.22 \mathrm{~mm}$.

coronary artery bypass graft.

I The odds ratio stated is for risk of Ml and coronary deathonly 


\section{5: Risk factors for both type 2 diabetes and cardiovascular diseases}

Subjects with type 2 diabetes have an increased risk of CVD and it has been shown that they have increased risk rates of all cardiovascular disorders affecting heart, brain and peripheral vessels (176). Specifically, all manifestations of CHD (myocardial infarction, sudden death and angina pectoris) are at least twice as common in patients with type 2 diabetes as in nondiabetic individuals (177). The risk for fatal and non-fatal CHD events is relatively higher in female type 2 diabetic patients than in male type 2 diabetic patients, and is largely independent of age. The Framingham study reported a relative risk for $\mathrm{CHD}$ mortality of 1.7 in diabetic men relative to non-diabetic men, and a relative risk of 3.3 in diabetic women compared with their non-diabetic counterparts (178). Moreover, subjects with type 2 diabetes without previous myocardial infarction (MI) have a risk of $\mathrm{MI}$ as high as non-diabetic subjects with previous $\mathrm{MI}(179)$. MI is more often silent in type 2 diabetes patients and this may hamper adequate diagnosis and treatment. They also suffer from higher rates of complications or even higher mortality rates after suffering cardiovascular events than subjects without diabetes (180).

In addition to CHD, the occurrence of stroke and peripheral vascular disease is at least twofold higher in type 2 diabetes than in control subjects in all age groups. Higher mortality rates after stroke in diabetes have been found in several studies (181) and population-based studies have indicated that the risk for stroke is considerably elevated in type 2 diabetes (181). Furthermore, several epidemiological studies have shown a higher prevalence of absent peripheral leg and foot pulses in type 2 diabetes $(181,182)$, which is an indication of peripheral vascular disease. In the Framingham Heart Study, the 34-year age-adjusted incidence of intermittent claudication was 2.7 times higher in male diabetic patients and 3.4 times higher in female diabetic patients than in men and women without diabetes (183).

\subsection{1: Risk factors}

It is known that several predisposing factors simultaneously affect the development of CVD and diabetes. Among these concomitant factors are obesity, physical inactivity and unhealthy diet, heredity, gender, and advancing age (57). Other potential pathogenic processes in the development of both atherosclerosis and diabetes include elevated blood pressure, increased glycosylation of proteins, and oxidative stress (176). Prospective studies have shown that classical risk factors for CVD (high total/LDLcholesterol, elevated blood pressure, smoking) contribute in a similar way in diabetic patients as in non-diabetic individuals $(57,184)$. As risk factors for CVD are already present amongst those subjects with marked insulin resistance, even without any significant disturbance in glucose tolerance, the pre-diabetic state itself has to play a role in the pathogenesis of atherosclerosis in type 2 diabetes. Several prospective studies from different populations including a large number of subjects with type 2 diabetes have shown that glycaemic control is important for cardiovascular risk (13). However, cardiovascular disease in type 2 diabetes cannot be explained by major risk 
factors alone, because they predispose to chronic diseases with complex and often overlapping mechanisms, also called clustering.

\subsection{2: Metabolic syndrome}

Clustering of several cardiovascular risk factors has been the subject of debate since the introduction of the concept known $\boldsymbol{\infty}$ Syndrome $X$ in 1988 (185). However, Kylin already described clustering of the risk factors hypertension, hyperglycemia and hyperuricemia as early as in 1923 (5). Reaven suggested that Syndrome X was an important risk factor for cardiovascular disease and that insulin resistance and compensatory hyperinsulinemia underlie the clustering of the metabolic disturbances (185). Nowadays, metabolic syndrome seems to be the most appropriate and widely accepted term for clustering of cardiovascular risk factors. These risk factors are common in individuals with insulin resistance and include dyslipidemia, glucose intolerance, obesity and especially abdominal obesity, elevated blood pressure, and prothrombotic and proinflammatory factors (e.g. plasminogen activator inhibitor-1, fibrinogen, and inflammatory cytokines) (175). In addition, some investigators hold the opinion that hyperinsulinemia and insulin resistance are major determinants of atherosclerotic vascular disease. The most common combinations of components of the metabolic syndrome however, are obesity with hypertension or dyslipidemia, which are seen in about $50 \%$ of patients with type 2 diabetes and in $10-20 \%$ of subjects with normal glucose tolerance (186). The metabolic syndrome commonly precedes the onset of diabetes by several years and it has been shown that the metabolic syndrome predicts CHD (104).

The appearance of hyperglycemia in patients with the metabolic syndrome appears to accelerate atherosclerosis, possibly by enhanced formation of glycosylated proteins and advanced glycation products $(130,166)$ which can increase endothelial dysfunction (116). These direct consequences of hyperglycemia probably contribute to the microvascular disease underlying nephropathy and retinopathy, and they may promote macrovascular disease as well. Thus, detection of insulin resistance relatively early in life offers the opportunity to identify at an early stage those subjects at risk of developing dyslipidemia, hypertension, and ultimately type 2 diabetes. Type 2 diabetes can therefore be viewed as the end product of years of metabolic stress against a background of insulin resistance. It is important to understand and intervene early in the continuum of events that lead to CVD, starting with the metabolic syndrome as $t$ progresses to impaired fasting glucose and/or impaired glucose tolerance, and ultimately type 2 diabetes.

\subsection{3: Obesity}

Epidemiological studies have demonstrated that increased central obesity is associated with insulin resistance, early vascular 'stiffness' and poor endothelial function (176). Because increased central obesity is accompanied by increased plasma free fatty acid levels and increased triglycerides storage in liver and muscle, this may drive insulin resistance further (176). Increased central obesity is also associated with higher levels of inflammatory markers such as Greactive protein, interleukin-6, and tumor necrosis factor $-\alpha$, which all have been related to increased risk of diabetes, myocardial 
infarction, and stroke in subjects with and without type 2 diabetes (167). Therefore, increased central obesity may be a precursor for both atherosclerosis and diabetes.

\section{6: Conclusion}

Type 2 diabetes mellitus is the most common form of diabetes and it is estimated to increase in a pandemic manner over the next 10 to 20 years (4). Although the early symptoms are often not severe, the long-term effects of hyperglycemia result in, or are associated with, micro- and macrovascular diseases like retinopathy, nephropathy, and atherosclerosis $(1,187)$. Ultimately, this can lead to blindness, renal failure and CVD events such as myocardial infarction and stroke.

The atherosclerosis process is often slow and principally occurs in large and medium-sized arteries. Two theories exist nowadays to explain the early process of atherosclerosis, i.e. the response-to-injury hypothesis and the response-to-retention hypothesis (96). Although it is not clear yet which of the hypotheses are true, research seems to be more favourable to the response-to-retention hypothesis which states that lipid retention in the arterial wall is the key to the development of an early atherosclerotic lesion. Factors such as hyperlipidemia, smoking, hypertension, turbulent blood flow and lipoprotein oxidation may increase the harmful effects of lipid retention in the arterial wall and contribute to the development of an atherosclerotic lesion into an atherosclerotic plaque. When the fibrous cap of the plaque ruptures, thrombus formation and occlusion of the artery can result which can lead to myocardial infarction or stroke (123). Because of the slow nature of the atherosclerosis process, surrogate markers like intima-media thickness and arterial stiffness measurements have been used to investigate determinants of atherosclerosis at early stages of the process and to assess disease modifiers of the progression of atherosclerosis (135). Prospective studies have shown that both IMT and arterial stiffness can be used as good indicators of risk of CVD (147).

Both type 2 diabetes mellitus and CVD have common risk factors. Because the presence of type 2 diabetes increases the risk of CVD two to four times, it is crucial to understand how atherosclerosis develops and progresses in subjects with type 2 diabetes. Insulin resistance precedes other isk factors of the metabolic syndrome, and although the exact pathogenesis of CVD in type 2 diabetes is yet unknown, there is evidence that subjects in the pre-diabetic state, i.e. impaired glucose tolerance, impaired fasting glucose, or metabolic syndrome, are already at high risk for CVD events. Moreover, insulin resistance accelerates atherosclerosis long before the onset of hyperglycemia (188). Thus, early detection of insulin resistance is likely to identify those persons who are at risk of developing dyslipidemia, hypertension, impaired glucose tolerance, and ultimately diabetes.

\section{7: Outline of the thesis}

To study the effects of glucose tolerance on atherosclerosis, a prospective, population based study was created. The subjects for the present study, named the Cohort study Diabetes and Atherosclerosis Maastricht (CODAM), are participants of two large 
ongoing cohorts of the National Institute for Public Health and the Environment in the Maastricht area (Monitoring Project for Cardiovascular Diseases (189) and its predecessor (190)). In Chapter 2, the subjects, methods and design of the CODAM study are described. Also, a description of the differences between subjects with type 2 diabetes, impaired and normal glucose tolerance is given. A description of the design of the screening for the present study and the SLIM study. Study on Lifestyle-intervention and Impaired Glucose Tolerance Maastricht (21), as well as the screening results are given in Chapter 3.

To diagnose type 2 diabetes, an OGTT is recommended by the WHO (1). However, in the screening phase of large epidemiological studies, it may not be feasible to use venous blood sampling. As capillary blood sampling is easier, less expensive and less invasive to obtain, we validated capillary plasma glucose samples with venous plasma glucose samples for the diagnosis of type 2 diabetes and IGT according to the 1999 WHO criteria (1) in Chapter 4.

Intima-media thickness and arterial stiffness (reflected by Young's elastic modulus) are both surrogate markers of atherosclerosis in the large arteries. Few data exist however, on these markers combined in recently diagnosed type 2 diabetes or glucose intolerance. Therefore, we investigated in Chapter 5,1 ) whether the vessel wall properties differed between subjects with recently diagnosed type 2 diabetes, impaired glucose tolerance, and normal glucose tolerance, and 2) which variables predict the variance of these properties.

Hypertension is a very important risk factor for both type 2 diabetes and CVD. In Chapter 5, we report that hypertension predicts Young's elastic modulus and that pulse pressure, the difference between systolic and diastolic blood pressure, predicts intimamedia thickness. Because pulse pressure has been recognized as an independent predictor of CVD, we evaluated whether a high pulse pressure was associated with increased prevalence of metabolic and/or cardiovascular disorders, target organ damage, or abnormal vessel wall properties in Chapter 6 .

In Chapter 7, the main results of this thesis are discussed. It contains general conclusions about the development of atherosclerosis in type 2 diabetes as well as a discussion on public health implications. Furthermore, methodological aspects are addressed as well as suggestions for future research.

\section{References}

1. World Health Organization: Definition, diagnosis and classification of diabetes mellitus and its complications (1999) Report of a WHO Consultation. Part 1: Diagnosis and classification of diabetes mellitus. WHO Technical Report Series; 1-59

2. The Expert Committee on the Diagnosis and Classification of Diabetes Mellitus. Report of the Expert Committee on the Diagnosis and classification of diabetes mellitus. Diabetes Care 2003; 26: S5-S20

3. Laakso M, Lehto S. Epidemiology of macrovascular disease in diabetes. Diabetes Rev 1977; 5 : 294-315

4. Zimmet P. The burden of type 2 diabetes: are we doing enough? Diabetes Metab 2003; 29: 9-18

5. Isoomaa B. A major health hazard: The metabolic syndrome. Life Sciences 2003; 73: 2395-2411

6. Brown JB, Pedula KL, Bakst AW. The progressive cost of complications in type 2 diabetes mellitus. Arch Intern Med 1999; 159: 1873-1880

7. Williams R, Van Gaal L, Lucioni C. Assessing the impact of complications on the costs of type II diabetes. Diabetologia 2002; 45: S13-S17 
8. Jönsson B. Revealing the cost of Type II diabetes in Europe. Diabetologia 2002; 45: S5-S12

9. The Expert Committee on the Diagnosis and Classification of Diabetes Mellitus. Follow-up report on the diagnosis of diabetes mellitus. Diabetes Care 2003; 26: 3160-3167

10. Davidson MB, Landsman PB, Alexander CM. Lowering the criterion for impaired fasting glucose will not provide clinical benefit. Diabetes Care 2003; 26: 3329-3330

11. Genuth S. Lowering the criterion for impaired fasting glucose is in order. Diabetes Care 2003; 26: 3331-3332

12. Schriger DL, Lorber $\mathrm{B}$. Lowering the cut point for impaired fasting glucose. Where is the evidence? Where is the logic? Diabetes Care 2004; 27: 592-595

13. Reaven GM. Banting Lecture 1988: Role of insulin resistance in human disease. Diabetes 1988; 37: 1595-1607

14. Porte D, Jr. Banting lecture 1990. Beta-cells in type II diabetes mellitus. Diabetes $1991 ; 40$ : 166 180

15. Cefalu WT. Insulin resistance: cellular and clinical concepts. Exp Biol Med 2001; 226: 13-26

16. Kahn CR. Banting Lecture. Insulin action, diabetogenesis, and the cause of type II diabetes. Diabetes 1994; 43 : 1066-1084

17. Blake GJ, Ridker PM. C-reactive protein, subclinical atherosclerosis, and risk of cardiovascular events. Arterioscler Thromb Vasc Biol 2002; 22: 1512-1513

18. Tuomilehto J, Lindström J, Eriksson JG, et al. Prevention of type 2 diabetes mellitus by changes in lifestyle among subjects with impaired glucose tolerance. N Engl J Med 2001; 344:1343-50

19. Knowler WC, Barrett-Connor E, Fowler S, et al. Reduction in the incidence of type 2 diabetes with lifestyle intervention or metformin. N Engl J Med 2002; 346:393-403

20. Chiasson J, Josse RG, Gomis R. Hanefeld M, Karasik A, Laakso M. Acarbose for prevention of type 2 diabetes mellitus: the STOR NIDDM randomised trial. Lancet 2002; 359:2072-77

21. Scheen AJ. (Infocongress. Prevention of type 2 diabetes in obese patients: first results with orlistat in the XENDOS study). Rev Med Liege 2002; 57(9) : 617-21

22. Mensink M, Corpeleijn E, Feskens EJM, Kruijshoop M, Saris WHM, de Bruin TWA, Blaak EE. Study on lifestyle-intervention and impaired glucose tolerance Maastricht (SLIM): design and screening resuls. Diab Res Clin Pract 2003; 61: 49-58

23. Fletcher B, Gulanick M, Lamendola C. Risk factors for type 2 diabetes mellitus. J Cardiovasc Nurs. 2002; 16:17-23

24. Fujimoto WY. Background and recruitment data for the U.S. Diabetes Prevention Program. Diabetes Care 2000; 23 Suppl 2:B11-3

25. De Backer G, Ambrosioni,E, Borch-Johnsen K, Brotons C, Cifkova R, Dallongeville J, Ebrahim S, Faergeman O, Graham I, Mancia G, Cats VM, Orth-Gomer K, Perk J, Pyorala K, Rodicio JL, Sans S, Sansoy V, Sechtem U, Silber S, Thomsen T, Wood D. European guidelines on cardiovascular disease prevention in clinical practice: third joint task force of European and other societies on cardiovascular disease prevention in clinical practice (constituted by representatives of eight societies and by invited experts). Eur J Cardiovasc Prev Rehabil 2003; 10: S1-S10

26. Kavey RW, Daniels SR, Lauer RM, Atkins DL, Hayman LL, Taubert K. AHA Scientific Statement. American Heart Association guidelines for primary prevention of atherosclerotic cardiovascular disease beginning in childhood. Circulation 2003; 107: 1562-1567

27. Netherlands Heart Foundation. "Hart- en vaatziekten in Nederland 2004. Cijfers over leefstijl- en risicofactoren, ziekte en sterfte." 2004

28. Diet, nutrition and prevention of chronic diseases. World Health Organ Tech Rep Ser 2003; 916 : 1 149

29. Fletcher GF, Balady G, Blair SN, Blumenthal J, Caspersen C, Chaitman B, Epstein S, Sivarajan Froelicher ES, Froelicher VF, Pina IL, Pollock ML. Statement on exercise: benefits and recommendation for physical activity programs for all Americans: a statement for health professionals by the Committee on Exercise and Cardiac Rehabilitation of the Council on Clinical Cardiology. American Heart Association. Circulation 1996; 94: 857-862 
30. US Department of Health and Human Services. Physical Activity and Health: A Report of the Surgeon General. Atlanta, GA: US Department of Health and Human Services, Centers for Disease Control and Prevention, National Center for Chronic Diasease Prevention and Health Promotion; 1996

31. Bouchard C, Shephard RJ, Stephens T. Physical activity, fitness and health. International proceedings and consensus statement. 1993 May 5; Toronto, Canada. Champaign, III: Human Kinetics Publishers, 1994

32. National Center for Health Statistics Vital Statistics of the United States, 1988, Vol. II Mortality, Part A, Tables 1-27, 1-129. National Center for Health Statistics, Rockville, MD, 1991.

33. Lakatta EG. Age-associated cardiovascular changes in health: impact on cardiovascular disease in older persons. Heart Failure Reviews 2002; 7: $29-49$

34. European Society of Hypertension-European Society of Cardiology guidelines for the management of arterial hypertens ion. J Hypertens 2003; 21: 1011-1053

35. Castelli WP. Epidemiology of coronary heart disease: the Framingham study. Am J Med 1984; 76 : 4-12

36. Bakx JC, Beldstra MI, van den Hoogen HJM, Zielhuis GA, Thien Th, van Weel C, van den Bosch WJHM. Blood pressure and cardiovascular morbidity and mortality in a Dutch population: The Nijmegen Cohort Study. Prev Med 2001; 32: 142-147

37. Call EE, Thun MJ, Petrelli JM, Rodriguez C, Heath CW jr. Body-mass index and mortality in a prospective cohort of US adults. N Engl J Med 1999; 341: 1097-1105

38. Schunkert H. Obesity and target organ damage: the heart. Int J Obes 2002; 26: S15-S20

39. Hubert HB, Feinleib M, McNamara PM, Castelli WP. Obesity as an independent risk factor for cardiovascular disease: a 26-year follow -up of participants in the Framingham Heart Study. Circulation 1983; 67: 968-977

40. Seidell JC. Time trends in obesity: an epidemiological perspective. Horm Metab Res 1997a; 29: 155-158

41. Alexander JK. Obesity and coronary heart disease. Am J Med Sci 2001; 321: 215-224

42. Barnes RW, Liebman Pr, Marszalek PB, Kirk CL, Goldman MH. The natural history of asymptomatic carotid disease in patients undergoing cardiovascular surgery. Surgery 1981; 90 : 1075-1083

43. Poole-Wilson PA. Natural history of minor coronary events. Eur Heart J 1984; 5: 69-72

44. Engström G, Hedblad B, Janzon L, Juul-Möller S. Ventricular arrhythmias during 24-h ambulatory ECG recording: incidence, risk factors and prognosis in men with and without a history of cardiovascular disease. J Int Med 1999; 246: 363-372

45. Saito D, Shiraki T, Oka T, Kajiyama A, Takamura T. Risk factors indicating recurrent myocardial infarction after recovery from acute myocardial infarction. Circ J 2002; 66: 877-880

46. Eaton CB, Bostom AG, Yanek L, Laurino JP, McQuade W. Hume A, Selhub J. Family history and premature coronary heart disease. J Am Board Fam Pract 1996; 9: 382-383

47. Brunner D, Weisbort J, Meshulam N, Schwartz S, Gross J, Saltz-Rennert H, Altman S, Loebl K. Relation of serum total cholesterol and high-density lipoprotein cholesterol percentage to the incidence of definite coronary events: twenty-year follow -up of the Donolo-Tel Aviv Prospective coronary Artery Disease Study. Am J Cardiol 1987; 59: 1271-1276

48. Kardia SLR, Modell SM, Peyser PA. Family-centered approaches to understanding and preventing coronary heart disease. Am J Prev Med 2003; 24: 143-151

49. Lakier JB. Smoking and cardiovascular disease. Am J Med 1992; 93: 8S-12S

50. Nichols WW, O'Rourke M. McDonald's Blood Flow in Arteries: Theoretical, Experimental and Clinical Principles. 4th ed. 1998, Edward Arnold, London

51. Lovett JK, Howard SC, Rothwell PM. Pulse pressure is independently associated with carotid plaque ulceration. J Hypertens 2003; 21: 1669-1676 
52. Domanski M, Norman J, Wolz M, Mitchell G, Pfeffer M. Cardiovascular risk assessment using pulse pressure in the first National Health and Nutrition Examination Survey (NHANES I). Hypertension 2001; 38: 793-797

53. Benetos A, Safar M, Rudnichi A, et al. Pulse pressure: a predictor of long-term cardiovascular mortality in a French male population. Hypertension 1997; 30: 1410-1415

54. Holme I. Cholesterol reduction and its impact on coronary artery disease and total mortality. Am J Cardiol 1995; 76: 10C-17C

55. Rosengren A, Hagman M, Wedel $H$, Wilhelmsen L. Serum cholesterol and long-term prognosis in middle-aged men with myocardial infarction and angina pectors. A 16-year follow-up of the Primary Prevention Study in Goteborg. Sweden. Eur Heart J 1997; 18: 754-761

56. Packard C, Caslake M, Shepherd J. The role of small, dense low density lipoprotein (LDL): a new look. Int J Cardiol 2000; 74: S17-S22

57. Grundy SM, Benjamin IJ, Burke GL, Chait A, Eckel RH, Howard BV, Mitch W, Smith SC, Sowers JR. Diabetes and cardiovascular disease. A statement for healthcare professionals from the American Heart Association. Circulation 1999; 100: 1134-1146

58. Wilson PWF, D'Agostino RB, Levy D, Belanger AM, Silbershatz H, Kannel WB. Prediction of coronary heart disease using risk factor categories. Circulation 1998; 97: 1837-1847

59. Brunzell JD, Hokanson JE. Low -density and high-density lipoprotein subspecies and risk for premature coronary artery disease. Am J Med 1999; 107: 16S-18S

60. Wilson PW. High-density lipoprotein, low -density lipoprotein and coronary artery disease. Am J Cardiol 1990; 66: 7A-10A

61. Gordon DJ, Probstfield JL, Garrison RJ, Neaton JD, Castelli WP, Knoke JD, Jacobs DR Jr., Bangdiwala S, Tyroler HA. High-density lipoprotein cholesterol and cardiovascular disease. Four prospective American studies. Circulation 1989; 79: 8-15

62. Haffner SM, Lehto S, Ronnemaa T, Pyorala K, Laakso M. Mortality from coronary heart disease in subjects with type 2 diabetes and in nondiabetic subjects with and without prior myocardial infarction. N Engl J Med 1998; 339: 229-234

63. Lamarche B, Tchernof A, Dagenais GR, Cantin B, Lupien PJ, Deprés JP. Small dense LDL particles and the risk of ischemic heart disease: prospective results from the Québec Cardiovascular Study. Circulation 1997; 95: 69-75

64. Lamarche B, Lemieux I, Depres JP. The small, dense LDL phenotype and the risk of coronary heart disease: epidemiology, phatho-physiology and therapeutic aspects. Diabetes Metab 1999; 25: 199211

65. Hokanson JE, Austin MA. Plasma triglyceride level is a risk factor for cardiovascular disease independent of high-density lipoprotein cholesterol level: a meta-analysis of population-bas ed prospective studies. J Cardiovasc Risk 1996; 3: 213-229

66. Gotto AM. Triglyceride. The forgotten factor. Circulation 1998; 97: 1027-1028

67. Assmann G, Schulte H. Relation of high-density lipoprotein cholesterol and triglycerides to incidence of atherosclerotic coronary artery disease (the PROCAM experience). Prospective Cardiovascular Munster study. Am J Cardiol 1992; 70: 733-737

68. Fontbonne A, Charles MA, Thibult N, Richard JL, Claude JR, Warnet JM, Rosselin GE, Eschwege E. Hyperinsulinaemia as a predictor of coronary heart disease mortality in a healthy population: the Paris Prospective Study, 15-year follow -up. Diabetologia 1991; 34: 356-361

69. Lamarche B, Tchernof A, Mauriege P, Cantin B, Dagenais GR, Lupien PJ, Després J. Fasting insulin and apoplipoprotein B levels and low-density lipoprotein particle size as risk factors for ischemic heart disease. JAMA 1998; 279:1955-1961

70. Feskens EJ, Kromhout D. Hyperinsulinemia, risk factors, and coronary heart disease. The Zutphen Elderly Study. Arterioscler Thromb 1994; 14: 1641-1647

71. Walldius G, Jungner I, Holme I, Aastveit AH, Kolar W, Steiner E. High apolipoprotein B, low apolipoprotein A-I, and improvement in the prediction of fatal myocardial infaction (AMORIS study): a prospective study. Lancet 2001; 358: 2026-2033 
72. Talmud PJ, Hawe E, Miller GJ, Humphries SE. Nonfasting apolipoprotein B and triglyceride levels as a useful predictor of coronary heart disease risk in middle-aged UK men. Arterioscler Thromb Vasc Biol 2002; 22: 1918-1923

73. Lamarche B, Despres JP, Moorjani S, Cantin B, Dagenais GR, Lupien PJ. Prevalence of dyslipidemic phenotypes in ischemic heart disease (prospective results form the Quebec Cardiovascular Study). Am J Cardiol 1995; 75: 1189-1195

74. Gotto AM Jr, Whitney E, Stein EA, Shapiro DR, Clearfield M, Weis S, Jou JY, Langendorfer A, Beere PA, Watson DJ, Downs JR, de Cani JS. Relation between baseline and on-treatment lipid parameters and first acute major coronary events in the Air Force/Texas Coronary Atherosclerosis Prevention Study (AFCAPS/TexCAPS). Circulation 2000; 101: 477-484

75. Sharrett AR, Ballantyne CM, Coady SA, Heiss G, Sorlie PD, Catellier D, Patsch W. Coronary heart disease prediction from lipoprotein cholesterol levels, triglycerides, lipoprotein (a), apolipoproteins $A-I$ and B, and HDL density subf ractions: the Atherosclerosis Risk in Communities (ARIC) Study. Circulation 2001; 104: 1108-1113

76. Leng GC, Fowkes FGR, Lee AJ, Dunbar J, Housley E, Ruckley CV. Use of ankle brachial pressure index to predict cardiovascular events and death: a cohort study. BMJ 1996; 313: 1440-1443

77. Tsai AW, Folsom AR, Rosamond WD, Jones DW. Ankle-brachial index and 7-year ischemic stroke incidence. The ARIC study. Stoke 2001; 32: 1721-1724

78. Papamichael CM, Lekakis JP, Stamatelopoulos KS, Papaioannou TG, Alevizaki MK, Cimponeriu AT, Kanakakis JE, Papapanagiotuou A, Kalofoutis AT, Stamatelopuolos SF. Ankle-brachial index as a predictor of the extent of coronary atherosclerosis and cardiovascular events in patients with coronary artery disease. Am J Cardiol 2000; 86: 615-618

79. Dinneen SF, Gerstein HC. The association of microalbuminuria and mortality in non-insulindependent diabetes mellitus. A systematic overview of the literature. Arch Intern Med 1997; 157 : 1413-1418

80. Damsgaard EM, Froland A, Jorgensen OD, Mogensen CE. Microalbuminuria as predictor of increased mortality in elderly people. Brit Med J 1990; 300: 297-300

81. Ridker P. High-sensitivity Creactive protein and cardiovascular risk: Rationale for screening and primary prevention. Am J Cardiol 2003; 92: 17K-22K

82. Blake GJ, Ridker PM. Greactive protein and other inflammatory risk markers in acute coronary syndromes. J Am Coll Cardiol 2003; 41: 37S-42S

83. Sattar N, Gaw A, Scherbakova O, Ford I, O'Reilly D, Haffner SM, Isles C, Macfarlane PW, Packard CJ, Cobbe SM, Shepherd J. Metabolic syndrome with and without C-reactive protein as a predictor of coronary heart disease and diabetes in the West of Scotland Coronary Prevention Study. Circulation 2003; 108: 414-419

84. Laakso M. Cardiovascular disease in type 2 diabetes: challenge for treatment and prevention. J Intern Med 2001; 249: 225-235

85. Eikelboom JW, Lonn E, Genest J Jr, Hankey G, Yusuf S. Homocyst(e)ine and cardiovascular disease: a critical review of the epidemiological evidence. Ann Intern Med 1999; 131: 363-375

86. Welch GN, Loscalzo J. Homocysteine and atherothrombosis. N Engl J Med 1998; 338: 1042-1050

87. Bots ML, Launer LJ, Lindemans J, Hofman A, Grobbee DE. Homocysteine, atherosclerosis and prevalent cardiovascular disease in the elderly: The Rotterdam Study. J Intern Med 1997; 242: 339 357

88. Malinow MR, Nieto FJ, Szklo M, Chambless LE, Bond G. Carotid artery intimal-medial wall thickening and plasma homocyst(e)ine in asymptomatic adults. The Atherosclerosis Risk in Communities Study. Circulation 1993; 87: 1107-1113

89. Willinek WA, Ludwig M, Lennarz M, Holler T, Stumpe KO. High-normal serum homocysteine concentrations are associated with and increased risk of early atherosclerotic carotid artery wall lesions in healthy subjects. J Hypertens 2000; 18: 425-430

90. Mazza A, Motti C, Nulli A, Marra G, Gnasso A, Pastore A, Federici G, Cortese C. Lack of association between carotid intima-media thickness and methylenetetrahydrofolate reductase gene 
polymorphism or serum homocysteine in non-insulin-dependent diabetes mellitus. Metabolism 2000; 49: 718-723

91. Smilde TJ, van den Berkmortel FW, Boers GH, Wollersheim $H$, de Boo T, van Langen $H$, Stalenhoef AF. Carotid and femoral artery wall thickness and stiffness in patients at risk for cardiovascular disease, with special emphasis on hyperhomocysteinemia. Arterioscler Thromb Vasc Biol 1998; 18: 1958-1963

92. Stehouwer $\mathrm{CD}$. Heterogeneity of the association between plasma homocysteine and atherothrombotic disease: insights from studies of vascular structure and function. Clin Chem Lab Med 2001: 39: 705-709

93. Smith NL, Barziay JI, Shaffer D, Savage PJ, Heckbert SR, Kuller LH, Kronmal RA, Resnick HE, Psaty BM. Fasting and 2-hour postchallenge serum glucose measures and risk of incident cardiovascular events in the elderly. The Cardiovascular Health Study. Arch Intern Med 2002; 162: 209-216

94. Unwin N, Shaw J, Zimmet P, Alberti KGMM. Impaired glucose tolerance and impaired fasting glycaemia: the current status on definition and intervention. Diabet Med 2002; 19: 708-723

95. The DECODE Study Group. Glucose tolerance and mortality: comparison of WHO and American Diabetes Association diagnostic criteria. Lancet 1999; 354: 617-621

96. Williams KJ, Tabas I. The responseto-retention hypothesis of early atherogenesis. Arterioscler Thromb Vasc Biol 1995; 15: 551-561

97. Tall AR. Plasma high density lipoproteins. Metabolism and relationship to atherogenesis. J Clin Invest 1990; 86: 379-384

98. Maier JA, Barenghi L, Pagani F, Bradamante S, Comi P, Ragnotti G. The protective role of highdensity lipoprotein on oxidized-low-density-lipoprotein-induced U937/endothelial cell interactions. Eur J Biochem 1994; 221: 35-41

99. Mackness MI, Arrol S, Abbott C, Durrington PN. Protection of low-density lipoprotein against oxidative modification by high-density lipoprotein associated paraoxonase. Atherosclerosis 1993; 104:129-135

100. Krauss RM, Blanche PJ. Detection and quantitation of LDL subfractions. Curr Opin Lipidol 1992; 3 : 377-383

101. Juhan-Vague I, Alessi MC, Vague P. Increased plasma plasminogen activator inhibitor 1 levels. A possible link between insulin resistance and atherothrombosis. Diabetologia 1991; 34: 457-462

102. Matthews DR, Hosker JP, Rudenski AS, Naylor BA, Treacher DF, Turner RC. Homeostasis model assessment: insulin resistance and beta-cell function from fasting plasma glucose and insulin concentrations in man. Diabetologia 1985; 28: 412-419

103. Lehto S, Rönnemaa T, Pyörälä K, Laakso M. Cardiovasular risk factors clustering with endogenous hyperinsulinaemia predict death from coronary heart disease in patients with type 2 diabetes. Diabetologia 2000; 43: 148-155

104. Pradhan AD, Manson JE, Rifai N, Buring JE, Ridker PM. Greactive protein, Interleukin 6, and risk of developing type 2 diabetes mellitus. JAMA 2001; 286: 327-334

105. Kuta AE, Baum LL. Creactive protein is produced by a small number of normal human peripheral blood lymphocytes. J Exp Med 1986; 164: 321-326

106. Caballero AE, Arora S, Saouaf R, Lim SC, Smakowski P, Park JY, King GL, LoGerfo FW, Horton ES, Veves A. Microvascular and macrovascular reactivity is reduced in subjects at risk for type 2 diabetes. Diabetes 1999; 48: 1856-1862

107. Voge! RA, Benitez RM. Noninvasive assessment of cardiovascular risk: from Framingham to the future. Rev Cardiovasc Med 2000; $1: 3442$

108. Conroy RM, Pyörälä K, Fitzgerald AP, Sans S, Menotti A, De Backer G, De Bacquer D, Ducimetière P, Jousilahti P, Keil U, Njolstad I, Oganov RG, Thomsen T, Tunstall-Pedoe H, Tverdal A, Wedel H, Whincup P. Wilhelmsen L, Graham IM. Estimation of ten-year risk of fatal cardiovascular disease in Europe: the SCORE project. Eur Heart J 2003; 24: $987-1003$ 
109. De Visser CL, Bilo HJB, Thomsen TF, Groenier KH, Meyboom-De Jong B. Prediction of coronary heart disease: a comparison between the Copenhagen risk score and the Framingham risk score applied to a Dutch population. J Intern Med 2003; 253:553-562

110. Assmann G, Cullen $P$, Schulte $H$. Simple scoring scheme for calculating the risk of acute coronary events based on the 10-year follow -up of the Prospective Cardiovascular Münster (PROCAM) Study. Circulation 2002; 105: 310-315

111. Stevens RJ, Kothari V, Adler AI, Stratton IM, Holman RR. The UKPDS risk engine: a model for the risk of coronary heart disease in Type II diabetes (UKPDS 56). Clin Sci 2001; 101: 671-679

112. Khot UN, Khot MB, Bajzer CT, Sapp SK, Ohman EM, Brener SJ, Ellis SG, Lincoff AM, Topol EJ. Prevalence of conventional risk factors in patients with coronary heart disease. JAMA 2003; 290: 898-904

113. Greenland P, Knoll MD, Stamler J, Neaton JD, Dyer AR, Garside DB, Wilson PW. Major risk factors as antecedents of fatal and nonfatal coronary heart disease events. JAMA 2003; 290: 891-897

114. Hackam DG, Anand SS. Emerging risk factors for atherosclerotic vascular disease. A critical review of the evidence. JAMA 2003; 290: 932-940

115. Ross R. Atherosclerosis - An inflammatory disease. N Engl J Med 1999; 340: 115-126

116. Napoli C, D'Armiento FP, Mancini FP, Postiglione A, Witztum JL, Palumbo G, Palinski W. Fatty streak formation occurs in human fetal aortas and is greatly enhanced by maternal hypercholesterolemia: intimal accumulation of low density lipoprotein and its oxidation precede monocyte recruitment into early atherosclerotic lesions. J Clin Invest 1997; 100: 2680-2690

117. Ross R, Glomset JA. The pathogenesis of atherosclerosis. N Engl J Med 1976; 295: 369-377

118. Ross R, Glomset JA. The pathogenesis of ahterosclerosis. N Engl J Med 1976; $295: 420-425$

119. Ross R, Glomset J, Harker L. Response to injury and atherogenesis. Am J Pathol 1977; 86: 675684

120. Dicorleto PE, Chisolm GM. Participation of the endothelium in the development of the atherosclerotic plaque. Prog Lipid Res 1986; 25: 365-374

121. Steinke W, Els T, Hennerici M. Compensatory carotid artery dilation in early atherosclerosis. Circulation 1994; 89: 2578-2581

122. Lee RT, Libby P. The unstable atheroma. Arterioscler Thromb Vasc Biol 1997; 17: 1859-1867

123. Corti R, Farkouh ME, Badimon JJ. The vulnerable plaque and acute coronary syndromes. Am J Med 2002; 113: 668-680

124. Wissler RW. Morphological characteristics of the developing atherosclerotic plaque: animal studies and studies of lesions from young people. Atheroscler Rev 1991; 23: 91-103

125. Nielsen LB, Nordestgaard BG. Stender S, Kjeldsen K. Aortic permeability to LDL as a predictor of aortic cholesterol accumulation in cholesterol-fed rabbits. Arterioscler Thromb 1992; 12: 1402-1409

126. Thubrikar MJ, Keller AC, Holloway PW, Nolan SP. Distribution of low density lipoprotein in the branch and non-branch regions of the aorta. Atherosclerosis 1992; 97: 1-9

127. Brownlee M, Vlassara $H$, Cerami A. Nonenzymatic glycosylation products on collagen covalently trap low-density lipoprotein. Diabetes 1985; 34: 938-941

128. Camejo G, Waich S, Quintero G, Berrizbeitia ML, Lalaguna F. The affinity of low density lipoproteins for an arterial macromolecular complex: a study in ischemic heart disease and controls. Atherosclerosis 1976; 24: 341-354

129. Linden T, Bondjers G, Camejo G, Bergstrand R, Wilhelmsen L, Wiklund O. Affinity of LDL to a human arterial proteoglycan among male survivors of myocardial infarction. Eur J Clin Invest 1989; 19: $38-44$

130. Chisolm GM. Antioxidants and atherosclerosis: a current assessment. Clin Cardiol 1991; 14: 125130

131. Witztum JL, Steinberg D. Role of oxidized low density lipoprotein in atherogenesis. J Clin Invest 1991; 88: 1785-1792 
132. Steinberg $D$. Antioxidants in the prevention of human atherosclerosis: summary of the proceedings of a National Heart, Lung, and Blood Institute Workshop. September 5-6, 1991, Bethesda,

Maryland. Circulation 1992; 85: 2337-2344

133. Brown MD, Jin L, Jien ML, Matsumoto AH, Heim GA, Lusis AJ, Frank JS, Shi W. Lipid retention in the arterial wall of two mouse strains with different atherosclerosis susceptibility. J Lipid Res 2004; 45: 1155-1161

134. Bots ML, Grobbee DE. Intima media thickness as a surrogate marker for generalized atherosclerosis. Cardiovascular Drugs and Therapy 2002; 16: 341-351

135. Wittes J, Lakatos J, Probstfeld J. Surrogate endpoints in clinical trials. Stat Med 1989; 8: 415-425

136. Glagov S, Weisenberg E, Zarins CK, Stankunavicius R, Kolettis GJ. Compensatory enlargement of human atherosclerotic coronary arteries. N Engl J Med 1987; 316: 1371-1375

137. Probstfield JL, Byington RP, Egan DA, Espeland MA, Margitic SE, Riley WA Jr, Furberg CD. Methodological issures facing studies of atherosclerotic change. Circulation 1993; 87: I174-81

138. Wong M, Edelstein J, Wollman J, Bond MG. Ultrasonic-pathological comparison of the human arterial wall. Verification of intima-media thickness. Arterioscler Thromb 1993; 13:482-486

139. Pignoli P. Tremoli E, Poli A, Oreste P, Paoletti R. Intimal plus medial thickness of the arterial wall: a direct measurement with ultrasound imaging. Circulation 1986; 74: 1399-1406

140. Wendelhag I, Gustavsson T, Suurkala M, Berglund G, Wikstrand J. Ultrasound measurement of wall thickness in the carotid artery: Fundamental principles and description of a computerized analyzing system. Clin Physiol 1991: 11: 565-577

141. Mountauban van Swijndregt $A D$, De Lange EE, De Groot E, Ackerstaff RG. An in vivo evaluation of the reproducibility of intima-media thickness measurements of the carotid artery segments using Bmode ultrasound. Ultrasound Med Biol 1999; 25: 323-330

142. Oei HS S, Vliegenthart R, Hak E, Iglesias del Sol A, Hofman A, Oudkerk M, Witteman JCM. The association between coronary calcification assessed by electron beam computed tomography and measures of extracoronary atherosclerosis. The Rotterdam Coronary Calcification Study. J Am Coll Cardiol 2002; 39: 1745-1751

143. Salonen R, Salonen JT. Determinants of carotid intima-media thickness: a population-based ultrasonography study in Eastern Finnish men. J Intern Med 1991; 229: 225-231

144. Howard G, O'Leary DH, Zaccaro D, Haffner S, Rewers M, Hamman R, Selby JV, Saad MF, Savage P. Bergman R. Insulin sensitivity and atherosclerosis. Circulation 1996; 93: 1809-1817

145. Kiechl S, Willeit J. The natural course of atherosclerosis. Part II: Vascular Remodelling. Arterioscler Thromb Vasc Biol 1999; 19: 1491-1498

146. Stensland-Brugge E, Bonaa K, Joakimsen O, Njolstad I. Sex differences in the relationship of risk factors to subclinical carotid atherosclerosis measured 15 years later. The Tromso study. Stroke 2000; 31: 574-581

147. Bots ML, Dijk JM, Oren A, Grobbee DE. Carotid intima-media thickness, arterial stiffness and risk of cardiovascular disease: current evidence. J Hypertens 2002; 20: 2317-2325

148. Chambless LE, Heiss G, Folsom AR, Szklo M, Sharrett AR, Clegg LX. Association of coronary heart disease incidence with carotid arterial wall thickness and major risk factors: the Atherosclerosis Risk in Communities (ARIC) Study, 1987-1993. Am J Epidemiol 1997; 146: 483 494

149. Bots ML, Hoes AW, Koudstaal PJ, Hofman A, Grobbee DE. Common carotid intima-media thickness and risk of stroke and myocardial infarction: the Rotterdam Study. Circulation 1997; 96 : 1432-1437

150. Hodis HN, Mack WJ, LaBree L, Selzer RH, Liu CR, Liu CH, Azen SP. The role of carotid arterial intima-media thickness in predicting clinical coronary events. Ann Intern Med 1998; 128: 262-269

151. Salonen JT, Salonen R. Ultrasound B-mode imaging in observational studies of atherosclerotic progression. Circulation 1993; 87: I156-65 
152. O'Leary DH, Polak JF, Kronmal RA, Manolio TA, Burke GL, Worfson SD Jr. Carotid-artery intima and media thickness as a risk factor for myocardial infarction and stoke in older adults.

Cardiovascular Health Study Collaborative Research Group. N Engl J Med 1999; 340: 14-22

153. Cheng K-S, Mikhailidis DP, Hamilton G, Seifalian AM. A review of the carotid and femoral intimamedia thickness as an indicator of the presence of peripheral vascular disease and cardiovascular risk factors. Cardiovasc Res 2002; 54: 528-538

154. Bots ML, Iglesias del Sol A, Grobbee DE. Carotid intima-media thickness measurements in observational and intervention studies. Curr Res Vasc Dis 1998; 3: 274-283

155. Hulthe J, Wikstrand J, Fagerberg B. Relationship between C-reactive protein and intima-media thickness in the carotid and femoral arteries and to antibodies against oxidized low-density lipoprotein in healthy men: the Atherosclerosis and Insulin Resistance (AIR) Study. Clin Sci (Colch) 2001; 100: 371-378

156. Hak AE, Stehouwer CD, Bots ML, Polderman KH, Schalwijk CG, Westendorp IC et al. Associations of C-reactive protein with measures of obesity, insulin resistance, and subclinical atherosclerosis in healthy, middle-aged women. Arterioscler Thromb Vasc Biol 1999; 19: 1986-1991

157. Hoeks APG, Willekes C, Boutouyrie P, Brands PJ, Willigers JM, Reneman RS. Automated detection of local artery wall thickness based on M-line signal processing. Ultrasound Med Biol 1997; 23: 1017-1023

158. Van Bortel LM, Vanmolkot FH, van der Heijden-Spek JJ, Bregu M, Staessen JA, Hoeks AP. Does B-mode common carotid artery intima-media thickness differ from M-mode? Ultrasound Med Biol 2001: 27: 1333-1336

159. Bond MG, Ball M. Assessment of ultrasound B-mode imaging for detection and quantification of atherosclerotic lesions in arteries of animal (NHLBI No1-HN-12916). Bethesda, MD: National Heart, Lung and Blood Institute 1986

160. Roman MJ, Pini R, Pickering TG, Devereux RB. Non-invasive measurements of arterial compliance in hypertensive compared with normotensive adults. J Hypertens 1992; 10: S115-S118

161. Liang YL, Shiel LM, Teede H, Kotsopoulos D, McNeil J, Cameron JD, McGrath BP. Effects of blood pressure, smoking, and their interaction on carotid artery structure and function. Hypertension 2001: 37: 6-11

162. Tounian P, Aggoun Y, Dubern B, Vari.lle V, Guy-Grand B, Sidi D, Girardet J-P, Bonnet D. Presence of increased stiffness of the common carotid artery and endothelial dysfunction in severely obese children: a prospective study. Lancet 2001; 358: 1400-1404

163. Pasterkamp G, Schoneveld AH, van Wolferen W, Hillen B, Clarijs RJ, Haudenschild CC, Borst C. The impact of atherosclerotic arterial remodelling on percentage of luminal stenosis varies widely within the arterial system. Arterioscler Thromb Vasc Biol 1997; 17: 3057-3063

164. Safar ME, London GM, Asmar R, Frohlich ED. Recent advances on large arteries in hypertension. Hypertension 1998; 32: 156-161

165. Franklin SS. Do diabetes and hypertension interact to accelerate vascular aging? J of Hypertension 2002; 20: 1693-1696

166. Ulrich P. Cerami A. Protein glycation, diabetes, and aging. Recent Prog Horm Res 2001; 56: 1-21

167. Chen S, Khan ZA, Cukiernik M, Chakrabarti S. Differential activation of NF-kappa B and AR-1 in increased fibronectin synthesis in target organs of diabetic complications. Am J Physiol Endocrinol Metab 2003: 284: E1089-E1097

168. Van Greevenbroek MMJ, Vermeulen VMMJ, de Bruin TWA. Familial combined hyperlipidemia plasma stimulates protein secretion by HepG2 cells: identification of fibronectin in the differential secretion proteome. J Lipid Res 2002; 43: 1846-1854

169. Eckel RH, Wassef M, Chait A, Sobel B, Barrett E, King G, Lopes-Virella M, Reusch J, Ruderman N, Steiner G. Vlassara H. Prevention Conference VI. Diabetes and Cardiovascular Disease. Writing Group II: Pathogenesis of atherosclerosis in diabetes. Circulation 2002; 105: e138-e143 
170. Salomaa V, Riley W, Kark JD, Nardo C, Folsom AR. Non-insulin-dependent diabetes mellitus and fas ting glucose and insulin concentrations are associated with arterial stiffness indexes. The ARIC Study. Atherosclerosis Risk in Communities Study. Circulation 1995; 91: 1432-1443

171. Emoto M, Nishizawa Y, Kawagishi T, Maekawa K, Hiura Y, Kanda H, Izumotani K, Shoji T, Ishimura $\mathrm{E}$, Inaba M, Okuno $\mathrm{Y}$, Mori $\mathrm{H}$. Stiffness indexes beta of the common carotid and femoral arteries are associated with insulin resistance in NIDDM. Diabetes Care 1998; 21: 1178-1182

172. Van Bortel LM, Duprez D, Starmans-Kool MJ, Safar ME, Giannattasio C, Cockcroft J, Kaiser DR, Thuillez C. Clinical applications of arterial stiffness, Task Force IIt: Recommendations for user procedures. Am J Hypertens 2002; 15: 445-452

173. Barenbrock M, Kosch M, Joster E, Kisters K, Rahn KH, Hausberg M. Reduced arterial distensibility is a predictor of cardiovascular disease in patients after renal transplantations. J Hypertens 2002; 20: $79-84$

174. Blacher J, Pannier B, Guerin AP, Marchais SJ, Safar ME, London GM. Carotid arterial stiffness as a predictor of cardiovascular and all-cause mortality in end-stage renal disease. Hypertension 1998; 32: $570-574$

175. Van Dijk RA, Dekker JM, Nijpels G, Heine RJ, Bouter LM, Stehouwer CD. Brachial artery pulse pressure and common carotid artery diameter: mutually independent associations w ith mortality in subjects with a recent history of impaired glucose tolerance. Eur J Clin Invest 2001; 31: 756-763

176. Howard BV, Rodriguez BL, Bennett PH, Harris MI, Hamman R, Kuller LH, Pearson TA, WylieRosett J. Prevention Conference VI. Diabetes and cardiovascular disease. Writing group I: Epidemiology. Circulation 2002; 105: e132-e137

177. Pyörälä K, Laakso M, Uusitupa M. Diabetes and atherosclerosis: an epidemiologic review. Diabetes Metab Rev 1987: 3: 463-524

178. Kannel WB, McGee DL. Diabetes and cardiovascular disease. The Framingham study. JAMA 1979; 241: 2035-2038

179. Haffner SM, Lehto S, Ronnemaa T, Pyorala K, Laakso M. Mortality from coronary heart disease in subjects with type 2 diabetes and in nondiabetic subjects with and without prior myocardial infarction. N Engl J Med 1998; 339: 239-234

180. Olsson T, Viitanen M, Asplund K, Eriksson S, Hagg E. Prognosis after stroke in diabetic patients. A controlled prospective study. Diabetologia 1990; 33: 244-249

181. Laakso M, Lehto S. Epidemiology of risk factors for cardiovascular disease in diabetes and impaired glucose tolerance. Atherosclerosis 1998: S65-S73

182. Feskens EJ, Kromhout D. Glucose tolerance and the risk of cardiovascular disease: the Zutphen Study. J Clin Epidemiol 1992; 45: 1327-1334

183. Brand FN, Abbott RD, Kannel WB. Diabetes, intermittent claudication and risk of cardiovascular events. The Framingham Study. Diabetes 1989; 38: 504-509

184. Ridker PM, Buring JE, Cook NR, Rifai N. Greactive protein, the metabolic syndrome, and risk of incident cardiovascular events. An 8-year follow -up of 14719 initially healthy American women. Circulation 2003; 107: 391-397

185. Stratton IM, Adler AI, Neil HA, Matthews DR, Manley SE, Cull CA, Hadden D, Turner RC, Holman RR. Association of glycaemia with macrovascular and microvascular complications of type 2 diabetes (UKPDS 35): prospective observational study. BMJ 2000; 321:405-12

186. Kylin E. Studien ueber das Hypertonie-Hyperglykämie-Hyperurikämiesyndrom. Zentralblatt fuer Innere Medizin 1923; 44: 105-127Isomaa B. A major health hazard: The metabolic syndrome. Life Sciences 2003; 73 : 2395-2411

187. Craeger MA, Lüscher TF. Diabetes and vascular disease. Pathophysiology, clinical consequences, and medical therapy: Part I. Circulation 2003; 108: 1527-1532

188. Haffner SM, Stern MP, Hazuda HP, Mitchell BD, Patterson JK. Cardiovascular risk factors in confirmed prediabetic individuals: does the clock for coronary heart disease start ticking before the onset of clinical diabetes? JAMA 1990; 263: 2893-2898 
189. Van Dam RM, Grievink L, Ocke MC, Feskens EJ. Patterns of food consumption and risk factors for cardiovascular disease in the general Dutch population. Am J Clin Nutr 2003; 77:1156-63

190. Seidell JC, Verschuren WMM, Kromhout D. Prevalence and trend of obesity in The Netherlands 1987-1991. Int J Obes 1995; 19: 924927 
CHAPTER 2

Subjects, methods, and design of the Cohort study of Diabetes and Atherosclerosis Maastricht (CODAM) 
2.1: Subjects: screening and inclusion

2.2: Description of the visits for the CODAM study

2.3: Materials and methods

2.4: Description of subjects according to glucose tolerance status

2.5: Description of Impaired Glucose Tolerance (IGT) and Impaired Fasting Glucose (IFG)

Appendices with Chapter 2

2.6: Appendix: 'Letter of invitation for the screening of the SLIM and CODAM studies'

2.7: Appendix: 'Participation form for the screening of the SLIM and CODAM studies'

2.8: Appendix: 'Letter of invitation for participation in the CODAM study for NGT subjects'

2.9: Appendix: 'Letter of invitation for participation in the CODAM study for IGT and DM subjects'

2.10: Appendix: 'Information package' 


\section{1: Subjects: screening and inclusion}

Participants of two large ongoing cohorts of the National Institute for Public Health and the Environment (RIVM) in the Maastricht area (Monitoring Project for Cardiovascular Diseases (1) and its predecessor (2)), that were > 40 years of age, had a BMI > 25 $\mathrm{kg} / \mathrm{m}^{2}$ or one or more of the other risk factor(s) (Table 1), had been invited to participate in a screening for the Cohort study of Diabetes and Atherosclerosis Maastricht (CODAM). The invitation letter and participation form are given in Appendix 2.6 and 2.7. The CODAM study is a prospective, population based, cohort study in the Netherlands. The study is carried out in cooperation with the Hoorn study in the Netherlands and both studies combined are called the DIALOG study (DIAbetes, Lipids, Obesity, Genetics). The local Medical Ethical Committee of the University of Maastricht and University Hospital Maastricht approved the study, including screening, inclusion and follow-up stages. All participants gave written informed consent.

Table 1: Inclusion and exclusion criteria for CODAM.

\begin{tabular}{ll}
\hline Inclusion criteria: & Age $>40$ years \\
And & BMI $>25 \mathrm{~kg} / \mathrm{m}^{2}$, \\
or & Positive family history of type 2 diabetes mellitus, \\
Or & History of gestational diabetes, \\
Or & Use of antihypertensive medication, \\
or & Postprandial blood glucose $>6.0 \mathrm{mmol} / \mathrm{L}(108 \mathrm{mg} / \mathrm{dl})$, \\
Or & Glucosuria, \\
Or & combinations of the separate inclusion criteria
\end{tabular}

Exclusion criteria: Medication known to affects glucose metabolism Non-Caucasian ethnicity

From March 1999 until May 2000, 2715 subjects participated in the screening phase, and subjects reported in the morning between 08.00 and $09.30 \mathrm{a} . \mathrm{m}$. after an overnight fast (10-12 hours) for an oral glucose tolerance test (OGTT). Capillary glucose concentrations were measured at baseline and two hours after ingestion of a 75-g oral glucose load (Glucometer Elite $\AA$, Bayer, USA). According to the 1999 WHO criteria (see Chapter 1, Table 1), 226 of the 2715 subjects $(8.3 \%)$ were newly diagnosed DM, 385 (14.2\%) were IGT, 215 (7.9\%) had impaired fasting glucose (IFG) and $1889(69.6 \%)$ were classified as NGT. The results of this screening are presented in Chapter 3. Subjects were included in either the CODAM study or in the Study on Lifestyle-intervention and Impaired Glucose Tolerance Maastricht (SLIM), a lifestyle intervention study directed at a healthy diet and increased physical activity. All 226 newly diagnosed DM subjects and 728 randomly selected NGT subjects were invited to the inclusion phase of the CODAM study. Moreover, 49 participants of the monitoring cohorts who were known to have type 2 diabetes of recent onset, i.e. more than 1 year, but less than 4 years diagnosed with type 2 diabetes, were invited. The 385 subjects diagnosed with IGT either participated in the SLIM study $(\mathrm{N}=114)$, as described by Mensink et al. (3), or in the present study $(\mathrm{N}=129)$, while the remainder did not wish to 
participate. An example of the letters of invitation for subjects with NGT and with IGT $\alpha$ DM, as well as the enclosed information package, are given in Appendices 2.8, 2.9 and 2.10. Participants underwent a second OGTT with venous plasma glucose measurements in order to re-establish their glucose tolerance status. Eventually, a total of 574 subjects were included in the CODAM cohort study, of whom $147(25.6 \%)$ had type 2 diabetes ( 86 newly diagnosed by screening, 14 diagnosed less than 1 year and 47 recent onset, i.e. diabetes more than 1 year but less than 4 years), $129(22.5 \%)$ had IGT (104 IGT and 25 IFG), and 298 (51.9\%) were NGT subjects. All DM subjects combined are defined as "recently diagnosed" throughout this thesis.

\section{2: Description of the visits for the CODAM study}

Study participants reported at the metabolic unit at two occasions (time interval between 2 weeks to 10 months). The metabolic unit is a climate controlled clinical research room. During the first visit, inclusion in the study was formalized. Subjects had to report between 08.00 and 0.900 a.m. Informed consent forms were signed. At home, subjects have had to fill in a general questionnaire to determine lifestyle factors (4-9) as well as a questionnaire about quality of health care. Furthermore, subjects had been asked to bring a morning urine sample for the determination of urinary albumin concentration. Body weight was measured and systolic and diastolic blood pressures were measured using a Maxi Stable 3 (Speider \& Keller, Germany). Subsequently, an OGTT was done to determine glucose tolerance status during which additional blood samples were taken to determine $\mathrm{HbA} 1 \mathrm{c}$, blood lipids, insulin and anti-oxidants. Buffy coats were also collected. During the OGTT, a food frequency questionnaire (10) was filled in.

For the second visit, subjects were asked to bing another morning urine sample. During this visit, systolic and diastolic blood pressures were measured in the same way as during the first visit. Subsequently, carotid artery wall ultrasound measurements were carried out as a surrogate marker of atherosclerosis. During these measurements, systolic and diastolic blood pressures were measured with an automatic device, the OMRON 705CP (Nieuwegein, the Netherlands), to calculate vessel wall characteristics. Thereafter, Ankle/Brachial Index was measured as a marker of peripheral vascular disease. Furthermore, body height, body composition (skin fold thicknesses), and body fat distribution (waist and hip circumferences, sagittal and transversal diameters) were measured, as well as a 12-lead rest electrocardiogram.

\section{3: Materials and methods}

Medication Subjects were asked to report all presently used medication. Lipid lowering medication was stopped 10 days before the first visit and 2 days before the second visit. The halflife of the inhibitory effect of most statins on HMG-CoA-reductase is 2 to 3 hours, with the longest halflife of 20-30 h for atorvastatin (www.lipitor.com). Common knowledge from pharmacokinetic theory indicates that after 5 half-lives a new equilibrium is reached. With atorvastatin, no inhibitory effect on HMG-CoA-reductase 
should be present after 6.25 days (about one week), which means that there was no effect of atorvastatin during the first visit. However, during the second visit an effect of atorvastatin could still exist. During this visit however, no blood samples were taken and, as far as we know, lipid lowering medication has no direct effects on ultrasound measurements. All other medication was stopped the day before both visits, including antihypertensive medication.

Glucose tolerance Glucose tolerance was measured by a standard 75-g oral glucose tolerance test (OGTT) and defined according to the 1999 WHO criteria (11). Subjects arrived at the metabolic unit after an overnight fast. At first, a Venflon catheter (BectonDickinson, Sweden) was inserted into an antecubital vein and a blood sample was taken for measurement of fasting plasma glucose concentrations. Subsequently, a 75-g glucose load ( $82.5 \mathrm{~g}$ Dextrose monohydrate, Avebe, the Netherlands) in $250 \mathrm{ml}$ plain water was given. A few drops of lemon juice were added for taste. Another blood sample was taken after 30,60 and 120 minutes for the measurement of plasma glucose concentrations. Plasma glucose was measured with the hexokinase glucose-6phosphate dehydrogenase method (HK-G6PD method, ABX Diagnostics Glucose HK 125. Montpellier, France). In addition to venous plasma glucose measurements, capillary plasma glucose concentrations were measured at fasting and $2 \mathrm{~h}$ post-load in a subset of 350 subjects using a Glucameter Elite® (Bayer, USA) to validate capillary measurements as a screening tool. The results of this study are described in Chapter 4.

Blood parameters In addition to fasting plasma glucose concentrations, fasting plasma insulin concentration, $\mathrm{HbA} 1 \mathrm{c}$, total cholesterol, HDL- and LDL-cholesterol, triglycerides, non-esterified fatty acids (NEFA's or FFA, free fatty acids), apolipoprotein B (apoB), C. reactive protein (CRP), complement factor $3(\mathrm{C} 3)$, creatinine, and soluble intercellular adhesion molecule (ICAM) were measured from the fasting blood sample. Insulin was determined using a two-sided immunoradiometric test by the Endocrinological Laboratory at the University Hospital Free University Amsterdam (the Netherlands), using paired monoclonal antibodies (Medgenix Diagnostics, Fleurus, Belgium). This test is insulin specific and does not show cross reactivity with pro-insulin and split products. Intra- and inter-assay coefficients of variation were $5 \%$ and $6 \%$, respectively. $\mathrm{HbA} 1 \mathrm{C}$ was determined by HPLC (reference value $4.4-6.2 \%$ ) by the Department of Clinical Chemistry of the Academic Hospital Maastricht (the Netherlands). Total cholesterol, HDL-cholesterol and triglycerides were measured by enzymatic methods (Roche, Mannheim, Germany) by the Department of Clinical Chemistry of the University Hospital Free University Amsterdam (The Netherlands). LDL-cholesterol was calculated according to Friedewald et al. (12). Non-HDL cholesterol was calculated by subtracting the plasma HDL-cholesterol from total cholesterol concentration. An enzymatic colorimetric method (Wako NEFA C, Richmond, USA) was used for the quantitation of NEFA's (or FFA) at the Department of Clinical Chemistry of the Erasmus Medical Centre (Rotterdam, The Netherlands). Coefficients of variance ranged between $1.1 \%$ and $2.7 \%$. CRP was measured with a high-sensitive kit (Latex, Roche Diagnostics Nederland BV, Almere, the Netherlands). Plasma creatinine was determined with a Roche kit (Roche Diagnostics Nederland BV, Almere, the Netherlands). Soluble ICAM was measured by Elisa (Biosource, USA). ApoB and C3 were determined in serum by an autoanalyzer (Hitachi 912) with a Roche kit (Roche Diagnositics Nederland BV). 
CRP, creatinine, soluble ICAM, C3 and apoB were all determined at the Laboratory of Toxicology, Pathology and Genetics of the National Institute for Public Health and the Environment (Bilthoven, the Netherlands).

Anthropometry Height (in $\mathrm{cm}$ ) was measured upright against a stadiometer. Body weight to the nearest 100 grams was measured after an overnight fast, without shoes and wearing light indoor clothing. Body Mass Index (BMI) was calculated by dividing weight by height in $\mathrm{kg} / \mathrm{m}^{2}$. Waist circumference (in $\mathrm{cm}$ ) was measured at the level midway between the lateral lower rib margin and the spina iliaca anterior superior. Hip circumference (in $\mathrm{cm}$ ) was measured at the level of both trochanter majors. Both waist and hip circumferences were measured with the subject in standing position and Waist/Hip Ratio (WHR) was calculated. Sagittal and transversal diameter (in mm) were measured at the level of the spina iliaca anterior superior by a slide gauge with the subject in supine position on a hard couch with the subjects hands folded under the head. Skin fold measurements were repeated three times using a skin fold caliper at the biceps, triceps, subscapular and suprailiacal region on the non-dominant side of the body. The average value for every skin fold and sum of the average skin folds were calculated. The sum of the average skin folds was converted to a fat percentage by the table of Durnin and Womersley (13).

Blood pressure Hypertension is one of the major risk factors for the development of carotid atherosclerosis and peripheral arterial disease (14). Therefore, blood pressure was measured twice on each visit after 5 minutes of rest with a precision blood pressure instrument (Maxi Stable 3, Speider \& Keller, Germany) on the right arm in supine position. Cuff size was adjusted to the circumference of the arm. Systolic and diastolic blood pressures were defined according to the Korotkoff sounds I and V. The average of both the systolic and diastolic blood pressure (SBP and DBP) measurements of both visits was calculated and pulse pressure (PP) was defined as average SBP minus average DBP. Mean arterial pressure (MAP) was calculated as $\mathrm{DBP}+(\mathrm{PP} / 3)$. Hypertension was defined as SBP/DBP $\geq 140 / 90$ (14), or use of antihypertensive medication. Furthermore, during the second visit, SBP was measured with a standard Doppler device on both arms and ankles (a. tibialis posterior and a. dorsalis pedis) to calculate Ankle/Brachial Index: $\mathrm{ABI}$ a. tibialis posterior $=$ highest $\mathrm{SBP}$ a. tibialis posterior / highest SBP arms; $\mathrm{ABI}$ a. dorsalis pedis = highest SBP a. dorsalis pedis / highest SBP arms. An $\mathrm{ABI}<0.90$ is considered to be an indication for peripheral vascular disease $(15,16)$.

Electrocardiogram A standard 12-lead electrocardiogram (ECG) was made after 5 minutes rest with the subject in supine position, using a Marquette 12 SL ECG (GE Marquette Medical Systems, Milwaukee, MI, USA) or a Cardiette ${ }^{\circledR}$ daedalus view (H\&C Medical Devices Spa, Italy). Heart rate, QRS duration and QT-interval were automatically registered. Heart rate adjusted QTc-interval was calculated with a modified Bazett formula, using heart rate instead of RR interval for adjustment. A prolonged QTC-interval predicts all cause and cardiovascular mortality in DM patients (17) and the elderly $(18,19)$. QRS duration is considered a marker of metabolic stress (20) and represents conduction disturbances. The ECG was coded according to the Minnesota Code System (21) by the head of the ECG Service of Leiden University 
Medical Center, mr. AC Maan (PhD) (SEAL, the Netherlands). Left ventricular hypertrophy was considered to be present either as Sokolow-Lyons index without the presence of a bundle branch block ( $\mathrm{SV} 1+\mathrm{RV} 5$ or $6>38 \mathrm{~mm}$ ) (data missing $\mathrm{N}=286$ ), or Cornell voltage QRS duration product $>2440 \mathrm{~mm}^{*} \mathrm{~ms}(50,51)$ (data missing $\mathrm{N}=329$ ), or when the ECG was coded 3.1 or 3.3 (data missing $N=15$ ) (total data missing $N=12$ ).

Urine sample The morning urine samples of both visits were checked for glucose, proteins, $\mathrm{pH}$ and blood by a multiple reagent strip (Bayer Corporation, USA) and was frozen at $-80^{\circ} \mathrm{C}$. The albumin concentration of the first sample was determined by rate nephelometry (Array Protein System, Beckman, PaloAlto, USA) at the Department of Clinical Chemistry of the University Hospital Free University Amsterdam (the Netherlands). Microalbuminuria, an early marker of renal damage, is an indicator of increased cardiovascular risk, and the presence of microalbuminuria is considered an indication for antihypertensive treatment by the European Society of Hypertension (22). Microalbuminuria was considered to be present when albumin concentration $>20 \mathrm{mg} / \mathrm{L}$ (23).

Carotid artery Ultrasound Procedures Intima-media thickness (IMT) reflect structural vessel wall properties and distensibility and Young's elastic modulus of the common carotid artery (CCA) reflect both structural and functional vessel wall properties. IMT is frequently used in epidemiological studies as a quantitative measure since it has been validated as marker of vascular damage and of future cardiovascular risk (24). The reproducibility of distensibility and Young's elastic modulus measurements is sufficient for application in epidemiological studies $(25,26)$ and both measures have shown a relationship to cardiovascular risk factors (27).

Carotid intima-media thickness (IMT) was measured on both sides with ultrasound in M-mode (Ultramark 4+, ATL, Bothel, Washington, USA) by a linear array transducer of 7.5 $\mathrm{MHz}$ positioned perpendicular to the common carotid artery (CCA), as described before (28). The head was tilted at an angle of approximately $45^{\circ}$ to the contra-lateral side and both a. carotis communis were measured approximately $10-20 \mathrm{~mm}$ proximal to the bulbus after 15 minutes rest. Measurements were repeated seven times at both left and right CCA. The median value of the seven measurements was determined for the left and right side. Since no difference existed between right and left IMT median in the presently studied subjects, the average of the left and right median was used as a representative IMT value. When less than five measurements could be done, the measurement was considered missing. When measurements were obtained from one side only, the median value of that side was used in the analysis. The inter-observer coefficient of variation was $3.9 \%$, determined in 7 subjects on two occasions. The intraobserver coefficient of variation was $3.7 \%$ with observer 1 , determined in 5 subjects and $4.0 \%$ with observer 2, determined in 7 subjects. Systolic and diastolic blood pressures were measured with a validated automatic oscillometric blood pressure device (OMRON 705CP, Nieuwegein, the Netherlands) on the right arm before the procedure, and after the third and seventh measurement. The average of all systolic and diastolic measurements during the procedure was calculated. Brachial pulse pressure (PP) was defined as average systolic blood pressure minus average diastolic blood pressure and was used only to calculate distensibility, compliance and Young's 
elastic modulus. Brachial mean arterial pressure (MAP) was calculated as diastolic pressure + (pulse pressure / 3 ).

Vessel wall properties were assessed with an Ultramark 4+ (Ultramark 4+, ATL, Bothel, Washington, USA) and by using an echo wall tracking system at the same position in the common carotid artery (CCA) as used in IMT. The wall tracking system measures, non-invasively, the diastolic diameter $\mathrm{d}$ and distension $\Delta \mathrm{d}$, the change in diameter as function of time $(29,30)$. Distensibility (DIS), compliance (COM) and Young's elastic modulus (YEM) are defined as follows:

Distensibility DIS $=(\triangle \mathrm{A} / \mathrm{A}) / \mathrm{PP}$

Compliance $\mathrm{COM}=\triangle \mathrm{A} / \mathrm{PP}$

Young's elastic modulus YEM $=d /($ IMT * D)
(1/MPa)

$(\mathrm{mm} 2 / \mathrm{kPa})$

(MPa),

where $A$ is the diastolic lumen area (calculated by $\left.p^{*}\left(0.5^{*} d\right)^{2}\right), \Delta A$ the change in crosssectional area from diastole to systole (calculated by $\left.p^{*}\left((d+\Delta d)^{2}-d^{2}\right) / 4\right)$, and IMT is the IMT value resulting from the IMT measurement (29). All measurements were repeated seven times at both the left and right CCA. Measurements were repeated when the diameter showed a standard deviation of more than $1 \%$ or distension showed a standard deviation of more than $10 \%$. In calculations, we used the average of the left CCA diameter and distension because of the small number of missing values on this side, and because few subjects had the left hand side as the dominant side (6.3\%).

A complete ultrasound measurement protocol was obtained in $86.9 \%$ (499 of 574 ) of the subjects. IMT and distensibility measurements combined were available in $65.9 \%$ (378 of 574) subjects. Most common reasons for missing data, or subjects, were cardiac arrhythmia, longitudinal or oscillating movements of the carotid artery, (neck) obesity, or logistic problems. These factors had more impact in the DM group, because vessel wall properties were assessed successfully in $56.5 \%$ (83 of 147) of all DM subjects in the CODAM cohort compared to $62.8 \%$ of IGT subjects (81 of 129) and $71.8 \%$ (214 of 298) NGT subjects in the CODAM cohort. Variables that differed between subjects who did have an ultrasound and subjects who failed an ultrasound are shown in Table 2, 3 and 4. Subjects with DM who failed an ultrasound measurement were more obese than subjects who completed the measurement. IGT and NGT subjects who failed an ultrasound measurement were older, more obese and had a higher HbA1c than subjects who had a complete ultrasound protocol. Furthermore, NGT subjects with incomplete measurements also had a higher blood pressure and insulin level than subjects who had complete measurements.

Questionnaires Subjects filled in a questionnaire about physical activity (4), use of medication, medical history of themselves and their first-degree family members, family history of cardiovascular diseases and type 2 diabetes mellitus, smoking habits, ischaemic heart pain and intermittent claudication $(5,6)$, diabetes symptoms (diabetes checklist-2) (7), quality of life (RAND-36) (8), and depressive symptoms (CES-D, Dutch version) (9). The results are used to determine the impact of lifestyle factors. Subjects filled in a questionnaire about quality of health care and a validated semi-quantitative food frequency questionnaire (RIVM, Bilthoven, the Netherlands) as well (10). 
Table 2: Variables different between subjects with type 2 diabetes mellitus (DM) who had a complete ultrasound measurement (C) and who had an incomplete ultrasound measurement (I) and thus were not used in statistical analyses.

\begin{tabular}{|c|c|c|}
\hline & $\begin{array}{c}\text { DM-C } \\
(\mathrm{N}=83)\end{array}$ & $\begin{array}{c}\mathrm{DM}-1 \\
(\mathrm{~N}=63)\end{array}$ \\
\hline Age (years) & $60.3 \pm 6.4$ & $61.1 \pm 5.8$ \\
\hline BMI $\left(\mathrm{kg} / \mathrm{m}^{2}\right)$ & $29.3 \pm 3.9^{\circ}$ & $31.6 \pm 5.1$ \\
\hline Waist (cm) & $103.0 \pm 10.4^{\circ}$ & $107.4 \pm 12.7$ \\
\hline Hip (cm) & $104.5 \pm 8.1^{\circ}$ & $108.8 \pm 11.0$ \\
\hline WHR & $0.986 \pm 0.067$ & $0.999 \pm 0.069$ \\
\hline Sag. Diam. (mm) & $223.4 \pm 30.9^{\circ}$ & $239.7 \pm 36.2$ \\
\hline Trans. Diam. (mm) & $282.4 \pm 25.1$ & $287.2 \pm 25.3$ \\
\hline Fat perc. $(\%)$ & $34.1 \pm 6.2$ & $35.4 \pm 6.8$ \\
\hline Systolic BP (mmHg) & $147.7 \pm 18.7$ & $148.9 \pm 19.8$ \\
\hline Diastolic BP (mmHg) & $84.2 \pm 9.7$ & $85.1 \pm 9.8$ \\
\hline $\mathrm{PP}(\mathrm{mmHg})$ & $63.5 \pm 16.0$ & $63.8 \pm 16.2$ \\
\hline$A B I$ a.tibialis & $1.09 \pm 0.12$ & $1.15 \pm 0.20$ \\
\hline HbA1c (\%) & $6.8 \pm 1.2$ & $7.0 \pm 1.0$ \\
\hline Insulin $\mathrm{h}^{*}$ (pmol/L) & 75.5 & 91.5 \\
\hline
\end{tabular}

Data are mean $\pm \mathrm{SD} ;$ " unadjusted median value shown in table; " significantly different from subjects who failed ultrasound measurements; $B M I$ = body mass index; WHR = waisthip ratio; sag = sagittal; diam = diameter; trans = transversal; perc = percentage; $\mathrm{BP}=$ blood pressure; $\mathrm{PP}=$ pulse pressure; $\mathrm{ABI}=$ ankle/brachial index.

Table 3: Variables different between subjects with impaired glucose tolerance (IGT) who had a complete ultrasound measurement $(\mathrm{C})$ and who had an incomplete ultrasound measurement (I) and thus were not used in statistical analyses.

\begin{tabular}{lcc} 
& $\begin{array}{c}\text { IGT-C } \\
(\mathrm{N}=81)\end{array}$ & $\begin{array}{c}\text { IGT-I } \\
(\mathrm{N}=48)\end{array}$ \\
\hline Age (years) & $58.3 \pm 6.1^{*}$ & $61.2 \pm 7.4$ \\
BMI $\left(\mathrm{kg} / \mathrm{m}^{2}\right)$ & $28.4 \pm 3.8$ & $29.7 \pm 4.7$ \\
Waist $(\mathrm{cm})$ & $99.1 \pm 10.3$ & $102.8 \pm 13.5$ \\
Hip $(\mathrm{cm})$ & $104.6 \pm 8.2$ & $107.1 \pm 10.3$ \\
WHR & $0.947 \pm 0.071$ & $0.960 \pm 0.082$ \\
Sag. Diam. $(\mathrm{mm})$ & $215.0 \pm 34.5^{*}$ & $231.9 \pm 37.1$ \\
Trans. Diam. $(\mathrm{mm})$ & $277.9 \pm 29.2$ & $283.5 \pm 32.8$ \\
Fat perc. $(\%)$ & $33.0 \pm 7.1$ & $31.8 \pm 7.8$ \\
Systolic BP $(\mathrm{mmHg})$ & $142.7 \pm 20.4$ & $147.6 \pm 18.4$ \\
Diastolic BP $(\mathrm{mmHg})$ & $83.7 \pm 9.3$ & $85.4 \pm 10.5$ \\
PP $(\mathrm{mmHg})$ & $59.0 \pm 15.7$ & $62.2 \pm 13.1$ \\
ABI a.tibialis & $1.16 \pm 0.15^{\prime \prime}$ & $1.11 \pm 0.09$ \\
HbA1c (\%) & $5.8 \pm 0.4^{\prime \prime}$ & $6.0 \pm 0.4$ \\
Insulin Oh* (pmol/L) & 67.5 & 65.5 \\
\hline
\end{tabular}

Data are mean $\pm \mathrm{SD}$; " unadjusted median value shown in table; " significantly different from subjects who failed ultrasound measurements; $\mathrm{BMI}=$ body mass index; $\mathrm{WHR}=$ waisthip ratio; sag = sagittal; diam = diameter; trans = transversal; perc = percentage; $\mathrm{BP}=$ blood pressure; $\mathrm{PP}=$ pulse pressure; $\mathrm{ABI}=$ ankle/brachial index. 
Table 4: Variables different between subjects with normal glucose tolerance (NGT) who had a complete ultrasound measurement (C) and who had an incomplete ultrasound measurement (I) and thus were not used in statistical analyses.

\begin{tabular}{|c|c|c|}
\hline & $\begin{array}{c}\text { NGT-C } \\
(\mathrm{N}=214)\end{array}$ & $\begin{array}{l}\text { NGT-I } \\
(\mathrm{N}=84)\end{array}$ \\
\hline Age (years) & $57.4 \pm 7.3^{\circ}$ & $60.5 \pm 6.9$ \\
\hline BMI $\left(\mathrm{kg} / \mathrm{m}^{2}\right)$ & $26.9 \pm 3.3^{\circ}$ & $29.3 \pm 4.8$ \\
\hline Waist (cm) & $94.1 \pm 9.8 \#$ & $101.6 \pm 12.3$ \\
\hline $\mathrm{Hip}(\mathrm{cm})$ & $101.3 \pm 6.9^{\prime \prime}$ & $106.1 \pm 10.0$ \\
\hline WHR & $0.930 \pm 0.075^{\prime}$ & $0.958 \pm 0.076$ \\
\hline Sag. Diam. (mm) & $196.6 \pm 26.8^{\prime}$ & $220.3 \pm 34.6$ \\
\hline Trans. Diam. (mm) & $269.4 \pm 27.5^{\prime \prime}$ & $279.0 \pm 29.2$ \\
\hline Fat perc. $(\%)$ & $29.5 \pm 7.5^{*}$ & $31.6 \pm 7.8$ \\
\hline Systolic BP (mmHg) & $133.1 \pm 17.9^{\prime \prime}$ & $142.0 \pm 17.1$ \\
\hline Diastolic BP ( $\mathrm{mmHg}$ ) & $79.3 \pm 8.5^{\circ}$ & $82.4 \pm 7.8$ \\
\hline $\mathrm{PP}(\mathrm{mmHg})$ & $53.8 \pm 13.7^{*}$ & $59.7 \pm 13.4$ \\
\hline $\mathrm{ABI}$ a.tibialis & $1.15 \pm 0.11$ & $1.14 \pm 0.13$ \\
\hline $\mathrm{HbA} 1 \mathrm{c}(\%)$ & $5.6 \pm 0.4^{\prime \prime}$ & $5.7 \pm 0.4$ \\
\hline Insulin $\mathrm{h}^{*}$ (pmo/L) & $49.0^{\circ}$ & 59.0 \\
\hline
\end{tabular}

Data are mean \pm SD; " unadjusted median value shown in table; " significantly different from subjects who failed ultrasound measurements; $\mathrm{BMI}=$ body mass index; $\mathrm{WHR}=$ waisthip ratio; sag = sagittal; diam = diameter; trans = transversal; perc = percentage; $\mathrm{BP}=$ blood pressure; $\mathrm{PP}=$ pulse pressure; $\mathrm{ABI}=$ ankle/brachial index.

\section{4: Description of subjects according to glucose tolerance status}

In total, 352 men and 222 women (combined $\mathrm{N}=574$ ), who had a mean age of $59.1 \pm$ 7.0 years and BMI of $28.6 \pm 4.3 \mathrm{~kg} / \mathrm{m}^{2}$, participated in the CODAM study. All variables were adjusted for age and gender in statistical analyses. The variables urinary albumin concentration, triglycerides, insulin concentration, distensibility, compliance, Young's elastic modulus, and C-reactive protein had a skewed distribution and were logtransformed to satisfy conditions of normality. In tables however, their untransformed median values have been used for clarity.

DM subjects were significantly older than IGT or NGT subjects (Table 5). HbA1c, fasting and $2 \mathrm{~h}$ post-load venous plasma glucose concentration were significantly higher in DM subjects compared to IGT and NGT subjects. These results are inherent to the definition of DM, IGT and NGT. Total and non-HDL cholesterol were not different between the groups. HDL-cholesterol was lower in subjects with DM compared to IGT and NGT subjects, both in men and women, and triglycerides were significantly higher. Both low HDL-cholesterol and high triglycerides are characteristic lipoprotein abnormalities of diabetes as well as normal or high LDL-cholesterol (31). In the present study however, LDL-cholesterol was significantly lower in DM subjects compared to IGT and NGT subjects (Table 5). ApoB was not significantly different between the glucose tolerance groups. This metabolic phenotype (lower LDL cholesterol, higher triglycerides, but similar apoB) suggests the presence of small, dense LDL particles in DM subjects. Both FFA and insulin concentration were significantly higher in DM subjects compared to IGT and NGT subjects. In conclusion, DM subjects show 
abnormalities in HDL- and LDL-cholesterol, triglycerides, FFA and insulin in association with hyperglycemia, or, alternatively, these abnormalities precede hyperglycemia in the progression from IGT to DM, particularly the increased levels of FFA and triglycerides.

Except for height, all body composition variables were different between the glucose tolerance groups, i.e. weight, BMI, waist and hip circumference, WHR, sagittal and transversal diameter, sum of skin fold measurements, and fat percentage (Table 6). A remarkable incremental gradient for these measurements of bodycomposition was found from NGT to IGT and to DM. Therefore, increased body fatness, more abdominal obesity, and increased subcutaneous fat was a characteristic of recently diagnosed type 2 diabetes. This supports the concept that DM appears against a background of obesity $(3,32,33)$.

Systolic and diastolic blood pressure, pulse pressure and mean arterial pressure were significantly different between the groups, with the highest value in DM and the lowest in NGT subjects, regardless of whether the subjects used antihypertensive medication or not (Table 7). Ankle/Brachial Indexes of both arteries were significantly lower in DM compared to IGT and NGT subjects, which suggests more peripheral vascular disease $(15,16)$. Furthermore, urinary albumin concentration was significantly higher in DM subjects compared to the IGT and NGT subjects, which suggests that more early renal damage is present in subjects with DM than in subjects with IGT or NGT (22). A more detailed analysis and description of blood pressure variables is presented in Chapter 6 .

Heart rate and QRS duration were significantly higher in DM subjects compared to IGT and NGT subjects (Table 8). This indicated disturbances in conduction of the heart, suggesting higher metabolic stress for DM subjects than for IGT and NGT subjects (20). However, heart rate corrected QT-time was not different between DM, IGT and NGT subjects. As prolonged QTc-time is associated with a higher risk of all cause or CVD mortality (17-19), this suggests that recently diagnosed DM subjects may not be at increased risk of CVD events compared to IGT and NGT subjects.

Although in previous reports an increased IMT was found in subjects with DM $(34,35)$, no differences were found in the present study in IMT or distension on both sides between the glucose tolerance groups (Table 9). Diameter of the left CCA however, was significantly higher in DM subjects. Distensibility coefficient was significantly lower and Young's elastic modulus was significantly higher in DM subjects, which indicates a higher arterial vessel wall stiffness in DM subjects compared to IGT and NGT subjects. Compliance coefficient at the right side, but not the left side, was significantly lower in DM subjects, which also indicated higher stiffness. These data will be presented and discussed in more detail in Chapter 5 . 
Table 5: Age and venous blood parameters according to glucose tolerance status in the CODAM study.

\begin{tabular}{|c|c|c|c|c|c|}
\hline & $\mathrm{N}$ & $\begin{array}{c}\mathrm{DM} \\
(\mathrm{N}=147)\end{array}$ & $\begin{array}{c}\text { IGT } \\
(\mathrm{N}=129)\end{array}$ & $\begin{array}{c}\text { NGT } \\
(\mathrm{N}=298)\end{array}$ & $\begin{array}{l}\text { p-value } \\
\text { (trend) }\end{array}$ \\
\hline Age (years) & 574 & $\begin{array}{c}60.7 \\
(59.6-61.8)\end{array}$ & $\begin{array}{c}59.4 \\
(58.2-60.6)\end{array}$ & $\begin{array}{c}58.2 \\
(57.4-59.0)\end{array}$ & 0.001 \\
\hline $\mathrm{HbA1c}(\%)$ & 567 & $\begin{array}{c}6.9 \\
(6.7-7.0)\end{array}$ & $\begin{array}{c}5.8 \\
(5.7-6.0)\end{array}$ & $\begin{array}{c}5.6 \\
(5.6-5.7)\end{array}$ & $<0.001$ \\
\hline Fasting glucose (mmol/L) & 573 & $\begin{array}{c}7.9 \\
(7.8-8.1)\end{array}$ & $\begin{array}{c}5.9 \\
(5.7-6.1)\end{array}$ & $\begin{array}{c}5.3 \\
(5.2-5.4)\end{array}$ & $<0.001$ \\
\hline Glucose conc $0.5 \mathrm{~h}(\mathrm{mmol} / \mathrm{L})$ & 524 & $\begin{array}{c}12.7 \\
(12.4-13.1)\end{array}$ & $\begin{array}{c}10.3 \\
(10.0-10.6)\end{array}$ & $\begin{array}{c}8.8 \\
(8.6-9.0)\end{array}$ & $<0.001$ \\
\hline Glucose conc $1 \mathrm{~h}(\mathrm{mmol} / \mathrm{L})$ & 524 & $\begin{array}{c}15.3 \\
(14.9-15.7)\end{array}$ & $\begin{array}{c}11.2 \\
(10.8-11.6)\end{array}$ & $\begin{array}{c}8.4 \\
(8.1-8.6)\end{array}$ & $<0.001$ \\
\hline Glucose conc $2 \mathrm{~h}(\mathrm{mmol} / \mathrm{L})$ & 526 & $\begin{array}{c}13.3 \\
(12.9-13.6)\end{array}$ & $\begin{array}{c}8.5 \\
(8.2-8.9)\end{array}$ & $\begin{array}{c}5.6 \\
(5.4-5.8)\end{array}$ & $<0.001$ \\
\hline Total cholesterol (mmol/L) & 574 & $\begin{array}{c}5.16 \\
(5.00-5.32)\end{array}$ & $\begin{array}{c}5.30 \\
(5.13-5.47)\end{array}$ & $\begin{array}{c}5.21 \\
(5.10-5.33)\end{array}$ & NS \\
\hline $\begin{array}{l}\text { Non-HDL cholesterol } \\
(\mathrm{mmol} / \mathrm{L})\end{array}$ & 574 & $\begin{array}{c}4.10 \\
(3.94-4.27)\end{array}$ & $\begin{array}{c}4.14 \\
(3.97-4.32)\end{array}$ & $\begin{array}{c}3.95 \\
(3.83-4.06)\end{array}$ & NS \\
\hline $\begin{array}{l}\text { HDL cholesterol } \\
\text { (mmol/L) }\end{array}$ & 574 & $\begin{array}{c}1.06 \\
(1.01-1.11)\end{array}$ & $\begin{array}{c}1.16 \\
(1.10-1.21)\end{array}$ & $\begin{array}{c}1.27 \\
(1.23-1.30)\end{array}$ & $<0.001$ \\
\hline men & 352 & $\begin{array}{c}1.00 \\
(0.94-1.05)\end{array}$ & $\begin{array}{c}1.05 \\
(0.99-1.12)\end{array}$ & $\begin{array}{c}1.17 \\
(1.13-1.21)\end{array}$ & $<0.001$ \\
\hline women & 222 & $\begin{array}{c}1.16 \\
(1.06-1.27)\end{array}$ & $\begin{array}{c}1.33 \\
(1.22-1.43)\end{array}$ & $\begin{array}{c}1.41 \\
(1.35-1.48)\end{array}$ & $<0.001$ \\
\hline Triglycerides* (mmol/L) & 572 & $\begin{array}{c}1.80 \\
(0.60-6.70)\end{array}$ & $\begin{array}{c}1.65 \\
(0.50-4.10)\end{array}$ & $\begin{array}{c}1.20 \\
(0.40-4.70)\end{array}$ & $<0.001$ \\
\hline LDL cholesterol (mmol/L) & 568 & $\begin{array}{c}3.13 \\
(2.99-3.28)\end{array}$ & $\begin{array}{c}3.38 \\
(3.23-3.53)\end{array}$ & $\begin{array}{c}3.35 \\
(3.25-3.45)\end{array}$ & 0.026 \\
\hline Apolipoprotein B $(\mathrm{g} / \mathrm{L})$ & 573 & $\begin{array}{c}1.14 \\
(1.10-1.18)\end{array}$ & $\begin{array}{c}1.15 \\
(1.11-1.20)\end{array}$ & $\begin{array}{c}1.11 \\
(1.08-1.14)\end{array}$ & NS \\
\hline Free fatty acids (mmol/L) & 573 & $\begin{array}{c}0.60 \\
(0.57-0.63)\end{array}$ & $\begin{array}{c}0.55 \\
(0.52-0.58)\end{array}$ & $\begin{array}{c}0.48 \\
(0.46-0.50)\end{array}$ & $<0.001$ \\
\hline Fasting insulin ${ }^{*}(\mathrm{pmol} / \mathrm{L})$ & 568 & $\begin{array}{c}86.5 \\
(22.0-395.0)\end{array}$ & $\begin{array}{c}67.0 \\
(18.0-279.0)\end{array}$ & $\begin{array}{c}52.0 \\
(20.0-213.0)\end{array}$ & $<0.001$ \\
\hline
\end{tabular}

Data are mean ( $95 \%$ confidence interval) and are corrected for age and gender (except for age, that is corrected for gender only); " unadjusted median value (min-max) shown in table, but p-value trend calculated with log-transformed values, adjusted for age and gender; NS = non significantly different. 
Table 6: Body composition variables according to glucose tolerance status in the CODAM study.

\begin{tabular}{|c|c|c|c|c|c|c|}
\hline \multicolumn{2}{|l|}{$+2 x^{2}$} & $\mathrm{~N}$ & $\begin{array}{c}\mathrm{DM} \\
(\mathrm{N}=147)\end{array}$ & $\begin{array}{c}\text { IGT } \\
(\mathrm{N}=129)\end{array}$ & $\begin{array}{c}\text { NGT } \\
(\mathrm{N}=298)\end{array}$ & p-value (trend) \\
\hline \multicolumn{2}{|l|}{ Height (cm) } & 574 & $\begin{array}{c}170.0 \\
(169.1-171.0)\end{array}$ & $\begin{array}{c}171.7 \\
(170.7-172.7)\end{array}$ & $\begin{array}{c}171.0 \\
(170.4-171.7)\end{array}$ & NS \\
\hline \multicolumn{2}{|l|}{ Weight (kg) } & 573 & $\begin{array}{c}87.9 \\
(85.8-90.0)\end{array}$ & $\begin{array}{c}85.3 \\
(83.0-87.6)\end{array}$ & $\begin{array}{c}80.7 \\
(79.3-82.2)\end{array}$ & $<0.001$ \\
\hline \multicolumn{2}{|l|}{ BMI $\left(\mathrm{kg} / \mathrm{m}^{2}\right)$} & 573 & $\begin{array}{c}30.4 \\
(29.7-31.0)\end{array}$ & $\begin{array}{c}28.9 \\
(28.2-29.6)\end{array}$ & $\begin{array}{c}27.6 \\
(27.1-28.0)\end{array}$ & $<0.001$ \\
\hline \multirow[t]{3}{*}{ Waist $(\mathrm{cm})$} & all & 568 & $\begin{array}{c}104.4 \\
(102.6-106.2)\end{array}$ & $\begin{array}{c}100.5 \\
(98.6-102.4)\end{array}$ & $\begin{array}{c}96.4 \\
(98.8-103.0)\end{array}$ & $<0.001$ \\
\hline & men & 347 & $\begin{array}{c}107.1 \\
(105.0-109.1)\end{array}$ & $\begin{array}{c}103.4 \\
(101.1-105.7)\end{array}$ & $\begin{array}{c}98.9 \\
(97.3-100.4)\end{array}$ & $<0.001$ \\
\hline & women & 221 & $\begin{array}{c}100.0 \\
(96.7-103.3)\end{array}$ & $\begin{array}{c}95.8 \\
(92.7-99.0)\end{array}$ & $\begin{array}{c}92.7 \\
(90.6-94.8)\end{array}$ & $<0.001$ \\
\hline \multirow[t]{3}{*}{$\mathrm{Hip}(\mathrm{cm})$} & all & 565 & $\begin{array}{c}106.6 \\
(105.2-108.0)\end{array}$ & $\begin{array}{c}105.5 \\
(104.0-107.0)\end{array}$ & $\begin{array}{c}102.6 \\
(101.6-103.6)\end{array}$ & $<0.001$ \\
\hline & men & 347 & $\begin{array}{c}105.2 \\
(103.7-106.8)\end{array}$ & $\begin{array}{c}104.1 \\
(102.3-105.8)\end{array}$ & $\begin{array}{c}101.2 \\
(100.1-102.4)\end{array}$ & $<0.001$ \\
\hline & women & 218 & $\begin{array}{c}108.8 \\
(105.9-111.6)\end{array}$ & $\begin{array}{c}107.6 \\
(104.9-110.3)\end{array}$ & $\begin{array}{c}104.9 \\
(103.1-106.7)\end{array}$ & 0.017 \\
\hline \multirow[t]{3}{*}{ WHR } & all & 564 & $\begin{array}{c}0.980 \\
(0.971-0.990)\end{array}$ & $\begin{array}{c}0.953 \\
(0.943-0.963)\end{array}$ & $\begin{array}{c}0.941 \\
(0.934-0.947)\end{array}$ & $<0.001$ \\
\hline & men & 347 & $\begin{array}{c}1.017 \\
(1.00-1.027)\end{array}$ & $\begin{array}{c}0.993 \\
(0.981-1.005)\end{array}$ & $\begin{array}{c}0.976 \\
(0.968-0.984)\end{array}$ & $<0.001$ \\
\hline & women & 217 & $\begin{array}{c}0.922 \\
(0.903-0.940)\end{array}$ & $\begin{array}{c}0.890 \\
(0.873-0.907)\end{array}$ & $\begin{array}{c}0.885 \\
(0.873-0.896)\end{array}$ & 0.002 \\
\hline \multicolumn{2}{|c|}{$\begin{array}{l}\text { Sagittal diameter } \\
(\mathrm{mm})\end{array}$} & 565 & $\begin{array}{c}229.3 \\
(223.9-234.7)\end{array}$ & $\begin{array}{c}221.4 \\
(215.7-227.1)\end{array}$ & $\begin{array}{c}203.8 \\
(200.1-207.5)\end{array}$ & $<0.001$ \\
\hline \multicolumn{2}{|c|}{$\begin{array}{l}\text { Transversal diameter } \\
(\mathrm{mm})\end{array}$} & 565 & $\begin{array}{c}283.7 \\
(279.2-288.2)\end{array}$ & $\begin{array}{c}280.2 \\
(275.4-285.0)\end{array}$ & $\begin{array}{c}272.4 \\
(269.2-275.5)\end{array}$ & $<0.001$ \\
\hline \multicolumn{2}{|c|}{$\begin{array}{l}\text { Sum of skin folds } \\
(\mathrm{mm})\end{array}$} & 423 & $\begin{array}{c}81.8 \\
(77.7-86.0)\end{array}$ & $\begin{array}{c}70.0 \\
(65.4-74.6)\end{array}$ & $\begin{array}{c}59.5 \\
(56.7-62.4)\end{array}$ & $<0.001$ \\
\hline \multicolumn{2}{|c|}{ Fat percentage $(\%)$} & 421 & $\begin{array}{c}35.1 \\
(34.2-36.0)\end{array}$ & $\begin{array}{c}32.4 \\
(31.4-33.4)\end{array}$ & $\begin{array}{c}30.0 \\
(29.3-30.6)\end{array}$ & $<0.001$ \\
\hline
\end{tabular}

Data are mean ( $95 \%$ confidence interval) and corrected for age; $\mathrm{N}=$ number of measurements. 
Table 7: Blood pressure measurements according to glucose tolerance status in the CODAM study.

\begin{tabular}{|c|c|c|c|c|c|}
\hline & $\mathrm{N}$ & $\begin{array}{c}\text { DM } \\
(\mathrm{N}=147)\end{array}$ & $\begin{array}{c}\text { IGT } \\
(\mathrm{N}=129)\end{array}$ & $\begin{array}{c}\text { NGT } \\
(\mathrm{N}=298)\end{array}$ & $\begin{array}{l}\text { p-value } \\
\text { (trend) }\end{array}$ \\
\hline Systolic BP (mmHg) & 573 & $\begin{array}{c}146.7 \\
(143.9-149.6)\end{array}$ & $\begin{array}{c}144.2 \\
(141.2-147 . .3)\end{array}$ & $\begin{array}{c}136.4 \\
(134.4-138.5)\end{array}$ & $<0.001$ \\
\hline Diastolic BP (mmHg) & 573 & $\begin{array}{c}84.3 \\
(82.8-85.8)\end{array}$ & $\begin{array}{c}84.3 \\
(82.8-85.9)\end{array}$ & $\begin{array}{c}80.2 \\
(79.2-81.3)\end{array}$ & $<0.001$ \\
\hline $\mathrm{PP}(\mathrm{mmHg})$ & 574 & $\begin{array}{c}62.4 \\
(60.3-64.6)\end{array}$ & $\begin{array}{c}59.9 \\
(57.6-62.2)\end{array}$ & $\begin{array}{c}56.2 \\
(54.7-57.7)\end{array}$ & $<0.001$ \\
\hline MAP $(\mathrm{mmHg})$ & 573 & $\begin{array}{c}105.1 \\
(103.3-106.9)\end{array}$ & $\begin{array}{c}104.3 \\
(102.4-106.2)\end{array}$ & $\begin{array}{c}99.0 \\
(97.7-100.2)\end{array}$ & $<0.001$ \\
\hline$A B I$ a. dorsalis & 568 & $\begin{array}{c}1.08 \\
(1.06-1.10)\end{array}$ & $\begin{array}{c}1.11 \\
(1.09-1.13)\end{array}$ & $\begin{array}{c}1.13 \\
(1.12-1.15)\end{array}$ & $<0.001$ \\
\hline$A B I$ a. tibialis & 572 & $\begin{array}{c}1.11 \\
(1.09-1.13)\end{array}$ & $\begin{array}{c}1.14 \\
(1.12-1.16)\end{array}$ & $\begin{array}{c}1.15 \\
(1.14-1.16)\end{array}$ & 0.007 \\
\hline $\begin{array}{l}\text { Urinary albumin } \\
\text { concentration* }(\mathrm{mg} / \mathrm{l})\end{array}$ & 574 & $\begin{array}{c}4.40 \\
(2.00-231.00)\end{array}$ & $\begin{array}{c}3.40 \\
(2.00-388.00)\end{array}$ & $\begin{array}{c}3.50 \\
(2.00-227.00)\end{array}$ & $<0.001$ \\
\hline $\begin{array}{l}\text { Use of antihyp. } \\
\text { medication (\%) }\end{array}$ & 573 & 54.4 & 40.3 & 25.5 & $<0.05$ \\
\hline \multicolumn{6}{|c|}{$\begin{array}{l}\text { Data are mean ( } 95 \% \text { conf idence interval) and are corrected for age and gender; }{ }^{*} \text { unadjusted median value } \\
\text { (min-max) shown in table, but p-value trend calculated with log-transformed values, adjusted for age and } \\
\text { gender; } \mathrm{N}=\text { number of measurements; } \mathrm{BP}=\text { blood pressure; } \mathrm{PP}=\text { pulse pressure; } \mathrm{MAP}=\text { mean arterial } \\
\text { pressure; } \mathrm{ABI}=\text { ankle/brachial index; } \mathrm{a} .=\text { artery. }\end{array}$} \\
\hline & $N$ & $\begin{array}{c}\mathrm{DM} \\
(\mathrm{N}=147)\end{array}$ & $\begin{array}{c}\text { IGT } \\
(\mathrm{N}=129)\end{array}$ & $\begin{array}{c}\text { NGT } \\
(\mathrm{N}=298)\end{array}$ & $\begin{array}{l}\text { p-value } \\
\text { (trend) }\end{array}$ \\
\hline $\begin{array}{l}\text { Heart rate ECG } \\
\text { (beats/min) }\end{array}$ & 553 & $\begin{array}{c}66.1 \\
(64.4-67.8)\end{array}$ & $\begin{array}{c}61.3 \\
(59.5-63.1)\end{array}$ & $\begin{array}{c}59.9 \\
(58.7-61.1)\end{array}$ & $<0.001$ \\
\hline QRS-time (ms) & 553 & $\begin{array}{c}91.3 \\
(89.2-93.4)\end{array}$ & $\begin{array}{c}91.4 \\
(89.2-93.7)\end{array}$ & $\begin{array}{c}94.6 \\
(93.1-96.1)\end{array}$ & 0.006 \\
\hline QTc-time (ms) & 552 & $\begin{array}{c}415.2 \\
(412.3-418.1)\end{array}$ & $\begin{array}{c}409.3 \\
(406.2-412.4)\end{array}$ & $\begin{array}{c}411.8 \\
(409.8-413.8)\end{array}$ & NS \\
\hline
\end{tabular}

Data are mean (95\% confidence interval) and are corrected for age and gender; $\mathrm{N}=$ number of measurements. 
Table 9: Carotid artery wall characteristics according to glucose tolerance status in the CODAM study.

\begin{tabular}{|c|c|c|c|c|c|}
\hline & $\mathrm{N}$ & $\begin{array}{c}\mathrm{DM} \\
(\mathrm{N}=147)\end{array}$ & $\begin{array}{c}\text { IGT } \\
(\mathrm{N}=129)\end{array}$ & $\begin{array}{c}\text { NGT } \\
(\mathrm{N}=298)\end{array}$ & $\begin{array}{l}\text { p-value } \\
\text { (trend) }\end{array}$ \\
\hline IMT right (mm) & 469 & $\begin{array}{c}0.70 \\
(0.66-0.73)\end{array}$ & $\begin{array}{c}0.70 \\
(0.66-0.73)\end{array}$ & $\begin{array}{c}0.69 \\
(0.67-0.71)\end{array}$ & NS \\
\hline IMT left (mm) & 478 & $\begin{array}{c}0.71 \\
(0.68-0.75)\end{array}$ & $\begin{array}{c}0.71 \\
(0.67-0.75)\end{array}$ & $\begin{array}{c}0.70 \\
(0.67-0.72)\end{array}$ & NS \\
\hline IMT mean $(\mathrm{mm})$ & 499 & $\begin{array}{c}0.71 \\
(0.68-0.73)\end{array}$ & $\begin{array}{c}0.71 \\
(0.68-0.74)\end{array}$ & $\begin{array}{c}0.69 \\
(0.68-0.71)\end{array}$ & NS \\
\hline Diameter right CCA $(\mathrm{mm})$ & 476 & $\begin{array}{c}7.80 \\
(7.62-7.98)\end{array}$ & $\begin{array}{c}7.79 \\
(7.61-7.96)\end{array}$ & $\begin{array}{c}7.63 \\
(7.52-7.74)\end{array}$ & NS \\
\hline Diameter left CCA (mm) & 462 & $\begin{array}{c}7.75^{\circ} \\
(7.59-7.92)\end{array}$ & $\begin{array}{c}7.69 \\
(7.53-7.86)\end{array}$ & $\begin{array}{c}7.45^{\prime \prime} \\
(7.34-7.55)\end{array}$ & 0.001 \\
\hline $\begin{array}{l}\text { Distensibility coefficient right } \\
\mathrm{CCA}^{*}\left(\mathrm{MPa}^{-1}\right)\end{array}$ & 411 & $\begin{array}{c}15.1 \\
(5.8-29.7)\end{array}$ & $\begin{array}{c}16.3 \\
(5.7-39.7)\end{array}$ & $\begin{array}{c}18.3 \\
(6.5-50.9)\end{array}$ & $<0.001$ \\
\hline $\begin{array}{l}\text { Distensibility coefficient left CCA* } \\
\left(\mathrm{MPa}^{-1}\right)\end{array}$ & 408 & $\begin{array}{c}14.3 \\
(5.4-33.8)\end{array}$ & $\begin{array}{c}15.6 \\
(5.3-43.3)\end{array}$ & $\begin{array}{c}17.7 \\
(5.6-51.5)\end{array}$ & $<0.001$ \\
\hline $\begin{array}{l}\text { Compliance coefficient right } \\
\mathrm{CCA}^{*}\left(\mathrm{~mm}^{2} / \mathrm{kPa}\right)\end{array}$ & 411 & $\begin{array}{c}0.59 \\
(0.18-1.46)\end{array}$ & $\begin{array}{c}0.66 \\
(0.23-1.51)\end{array}$ & $\begin{array}{c}0.68 \\
(0.23-1.85)\end{array}$ & 0.009 \\
\hline $\begin{array}{l}\text { Compliance coefficient left CCA } \\
\left(\mathrm{mm}^{2} / \mathrm{kPa}\right)\end{array}$ & 408 & $\begin{array}{c}0.55 \\
(0.23-1.43)\end{array}$ & $\begin{array}{c}0.61 \\
(0.24-1.34)\end{array}$ & $\begin{array}{c}0.61 \\
(0.22-2.24)\end{array}$ & NS \\
\hline $\begin{array}{l}\text { Young's modulus right CCA* } \\
\text { (MPa) }\end{array}$ & 411 & $\begin{array}{c}0.74 \\
(0.28-5.88)\end{array}$ & $\begin{array}{c}0.70 \\
(0.28-1.84)\end{array}$ & $\begin{array}{c}0.57 \\
(0.21-4.49)\end{array}$ & 0.002 \\
\hline $\begin{array}{l}\text { Young's modulus left CCA* } \\
\text { (MPa) }\end{array}$ & 408 & $\begin{array}{c}0.83 \\
(0.29-3.48)\end{array}$ & $\begin{array}{c}0.65 \\
(0.20-3.00)\end{array}$ & $\begin{array}{c}0.60 \\
(0.19-3.76)\end{array}$ & 0.004 \\
\hline
\end{tabular}

Data are mean ( $95 \%$ confidence interval) and are corrected for age and gender; " unadjusted median value (min-max) shown in table, but p-value trend calculated with log-transformed values, adjusted for age and gender; " significantly different from the right side; $\mathrm{N}=$ number of measurements; IMT = intima-media thickness; $\mathrm{NS}=$ non significantly different; $\mathrm{CCA}=$ common carotid artery.

In addition to blood parameters like glucose, insulin and lipid parameters, selected inflammatory variables were determined. Soluble ICAM, C3, CRP, and creatinine were all significantly different between the DM, IGT and NGT subjects (Table 10). C3 is an acute phase reactant and increased synthesis of $\mathrm{C} 3$ is induced during acute inflammation (www.ncbi.nlm.nih.gov/entrez/dispomim.cgi?id=120700). The liver is the main site of synthesis, although small amounts are also produced by activated monocytes and macrophages. Soluble ICAM was significantly higher in subjects with DM, which suggest an increased risk on CVD (36-38). Also, C3 concentration was higher, which suggests a higher level of inflammation in DM subjects. The median value of CRP was highest in DM and lowest in NGT subjects. Although the effect of CRP is confounded by the effect of obesity $(39,40)$, CRP indicates increased risk on future MI and stroke in DM subjects $(41,42)$. Creatinine concentration was significantly lower in DM subjects than in IGT and NGT subjects. Because the albumin concentration in DM subjects in the present study was significantly higher than in IGT or NGT subjects and microalbuminuria precedes the appearance of higher creatinine levels (43), the reason for the lower creatinine concentration in DM subjects is presently unexplained. It may reflect a reduced mass of skeletal muscle in DM, most likely a long-term adaptation to a sedentary lifestyle. An alternative, more speculative, explanation is that the reduced muscle mass is governed by genetic factors, reflecting susceptibility to diabetes, as 
muscle is the most important contributor to glucose uptake from plasma and subsequent oxidation.

Table 10: Selected inflammatory variables according to glucose tolerance status in the CODAM study.

\begin{tabular}{|c|c|c|c|c|c|}
\hline & $\mathrm{N}$ & $\begin{array}{c}\mathrm{DM} \\
(\mathrm{N}=147)\end{array}$ & $\begin{array}{c}\text { IGT } \\
(\mathrm{N}=104)\end{array}$ & $\begin{array}{c}\text { NGT } \\
(\mathrm{N}=298)\end{array}$ & $\begin{array}{l}\text { p-value } \\
\text { (trend) }\end{array}$ \\
\hline $\begin{array}{l}\text { Soluble intercellular adhesion } \\
\text { molecule (ng/mL) }\end{array}$ & 573 & $\begin{array}{c}372.3 \\
(356.6-387.8)\end{array}$ & $\begin{array}{c}358.8 \\
(342.3-375.3)\end{array}$ & $\begin{array}{c}339.7 \\
(328.8-350.6)\end{array}$ & 0.002 \\
\hline Complement factor $3(\mathrm{~g} / \mathrm{L})$ & 571 & $\begin{array}{c}1.921 \\
(1.869-1.973)\end{array}$ & $\begin{array}{c}1.874 \\
(1.819-1.929)\end{array}$ & $\begin{array}{c}1.705 \\
(1.669-1.741)\end{array}$ & $<0.001$ \\
\hline C-reactive protein ${ }^{*}(\mathrm{mg} / \mathrm{L})$ & 572 & $\begin{array}{c}3.42 \\
(0.54-51.85)\end{array}$ & $\begin{array}{c}2.76 \\
(0.60-30.50)\end{array}$ & $\begin{array}{c}2.19 \\
(0.42-53.82)\end{array}$ & $<0.001$ \\
\hline Creatinine $(\mu \mathrm{mol} / \mathrm{L})$ & 573 & $\begin{array}{c}69.7 \\
(67.6-71.8)\end{array}$ & $\begin{array}{c}71.9 \\
(69.7-74.1)\end{array}$ & $\begin{array}{c}73.0 \\
(71.6-74.5)\end{array}$ & 0.011 \\
\hline
\end{tabular}

Data are mean ( $95 \%$ confidence interval) and are corrected for age and gender; " unadjusted median value (min-max) shown in table, but p-value trend calculated with logtransformed values, adjusted for age and gender; $\mathrm{N}=$ number of measurements.

There were no differences in gender or smoking habits among the glucose tolerance groups (Table 11). Besides lifestyle factors like smoking and exercise, it is known that DM also has a genetic component and part of this genetic component is transmitted maternally, although the underlying mechanism has not been clarified (44 46). Significantly more parents with DM were present in DM subjects compared to IGT or NGT subjects (Table 11). Furthermore, significantly more hypertension was present in subjects with DM compared to IGT and NGT subjects. Data from several epidemiologic studies have suggested that the prevalence of hypertension in patients with diabetes mellitus is approximately one-and-a-half to two times greater than in an appropriately matched nondiabetic population (47). Use of antihypertensive medication such as ACE inhibitors, $\beta$-blockers, and diuretics as well as lipid lowering medication was also significantly higher in DM subjects compared to IGT and NGT subjects (Table 12).

Glucose intolerance is one of the risk factors that can contribute to the metabolic syndrome according to both the WHO (11) and the Adult Treatment Panel (ATP) III of the National Cholesterol Education Program (NCEP) (48). Indeed, $78.2 \%$ of the subjects with DM also had the metabolic syndrome according to the definition of the NCEP (48), which was significantly more frequent than in subjects with IGT or NGT, i.e. $52.7 \%$ and $19.1 \%$ respectively (Table 11 ). Subjects with metabolic syndrome are at increased risk of CVD and CHD $(2,49)$. No differences however, existed in self-reported CVD and CHD or in the different disorders that make up CVD and CHD (Table 13). This is in contrast to the well-known increased prevalence of CHD and CVD, by a factor 2 to 4, in type 2 diabetes and IGT (49). These findings indicate that, in theory, it should be possible to prevent medical suffering from cardiovascular events in IGT and DM subjects, when detected in time and treated for the correct risk factors. 
Table 11: Percentage and Odds Ratio (OR) with confidence interval $(\mathrm{CI})$ in parentheses of males, smokers of cigarettes and cigars, hypertension, parents with diabetes and satisfaction to exercise guidelines according to glucose tolerance status in the CODAM study, adjusted for age and gender (except for percentage males).

\begin{tabular}{|c|c|c|c|c|c|}
\hline & & $\begin{array}{c}\text { NGT } \\
(\mathrm{N}=298)\end{array}$ & $\begin{array}{c}\text { IGT } \\
(\mathrm{N}=104)\end{array}$ & $\begin{array}{c}\mathrm{DM} \\
(\mathrm{N}=147)\end{array}$ & $\mathrm{N}$ \\
\hline \multirow[t]{2}{*}{ Male } & (\%) & 59.7 & 59.7 & 66.0 & 574 \\
\hline & OR (CI) & 1 & $1.0(0.7-1.5)$ & $0.8(0.5-1.1)$ & \\
\hline \multirow[t]{2}{*}{ Smoking, cigarettes } & (\%) & 16.5 & 17.8 & 14.3 & 573 \\
\hline & OR $(\mathrm{Cl})$ & 1 & $1.2(0.7-2.1)$ & $1.0(0.6-1.8)$ & \\
\hline \multirow[t]{2}{*}{ Ex-smoker } & (\%) & 48.8 & 52.7 & 59.9 & 573 \\
\hline & OR (CI) & 1 & $1.2(0.8-1.8)$ & $1.5(0.9-2.3)$ & \\
\hline \multirow[t]{2}{*}{ Cigar smoker } & (\%) & 4.1 & 3.1 & 4.9 & 563 \\
\hline & OR $(\mathrm{Cl})$ & 1 & $0.8(0.2-2.5)$ & $1.2(0.4-3.1)$ & \\
\hline \multirow[t]{2}{*}{ Parents with diabetes } & (\%) & 30.3 & 35.7 & 46.9 & 573 \\
\hline & OR (CI) & 1 & $1.3(0.8-2.0)$ & $2.1^{*}(1.4-3.2)$ & \\
\hline \multirow{2}{*}{$\begin{array}{l}\text { Hypertension ( } 2140 / 90 \text { or } \\
\text { hypertension medication) }\end{array}$} & (\%) & 51.5 & 69.0 & 81.0 & 573 \\
\hline & OR $(\mathrm{Cl})$ & 1 & $2.0^{*}(1.3-3.2)$ & $3.5^{*}(2.1-5.6)$ & \\
\hline Metabolic Syndrome & (\%) & 19.1 & 52.7 & 78.2 & 574 \\
\hline NCEP ATPIII (\%) & OR (CI) & 1 & $5.0^{*}(3.1-7.8)$ & $15.8^{*}(9.6-26.1)$ & \\
\hline
\end{tabular}

- OR significantly different from NGT; Data are given as percentages and as $\mathrm{OR}(\mathrm{Cl}) ; \mathrm{N}=$ number of measurements.

Table 12: Percentage and Odds Ratio (OR), with confidence interval $(\mathrm{CI})$ in parentheses, within groups of antihypertensives and use of lipid lowering medication according to glucose tolerance status in the CODAM study, adjusted for age and gender.

\begin{tabular}{|c|c|c|c|c|c|}
\hline & & $\begin{array}{c}\text { NGT } \\
(\mathrm{N}=298)\end{array}$ & $\begin{array}{c}\text { IGT } \\
(\mathrm{N}=104)\end{array}$ & $\begin{array}{c}\mathrm{DM} \\
(\mathrm{N}=147)\end{array}$ & $\mathrm{N}$ \\
\hline \multirow[t]{2}{*}{ Use of ACE inhibitor } & $(\%)$ & 6.7 & 11.6 & 21.8 & 573 \\
\hline & OR $(\mathrm{Cl})$ & 1 & $1.8(0.9-3.6)$ & $3.6^{*}(2.0-6.5)$ & \\
\hline \multirow[t]{2}{*}{ Use of alpha-blocker } & $(\%)$ & 1.0 & 0.8 & 1.4 & 573 \\
\hline & $\mathrm{OR}(\mathrm{Cl})$ & 1 & $0.7(0.1-7.4)$ & $0.8(0.1-5.4)$ & \\
\hline \multirow[t]{2}{*}{ Use of beta-blocker } & $(\%)$ & 14.8 & 24.0 & 29.3 & 573 \\
\hline & $\mathrm{OR}(\mathrm{Cl})$ & 1 & $1.8^{*}(1.1-3.0)$ & $2.2^{*}(1.4-3.6)$ & \\
\hline \multirow[t]{2}{*}{ Use of calcium antagonist } & $(\%)$ & 7.7 & 13.2 & 13.6 & 573 \\
\hline & OR $(\mathrm{Cl})$ & 1 & $1.8(0.9-3.5)$ & $1.6(0.8-3.1)$ & \\
\hline \multirow{2}{*}{$\begin{array}{l}\text { Use of central working } \\
\text { antihypertensive drugs }\end{array}$} & $(\%)$ & 0.3 & 0.8 & 0.7 & 573 \\
\hline & OR (Cl) & 1 & $2.1(0.1-33.9)$ & $1.8(0.1-29.2)$ & \\
\hline \multirow[t]{2}{*}{ Use of nitrates } & $(\%)$ & 7.7 & 7.8 & 6.1 & 573 \\
\hline & OR (Cl) & 1 & $1.0(0.4-2.1)$ & $0.7(0.3-1.5)$ & \\
\hline \multirow[t]{2}{*}{ Use of diuretics } & $(\%)$ & 6.1 & 13.2 & 17.0 & 573 \\
\hline & $\mathrm{OR}(\mathrm{Cl})$ & 1 & $2.2^{*}(1.1-4.6)$ & $3.0^{*}(1.5-5.7)$ & \\
\hline \multirow{2}{*}{$\begin{array}{l}\text { Use of angiotensin } \\
\text { antagonists }\end{array}$} & (\%) & 4.0 & 6.2 & 6.8 & 573 \\
\hline & OR $(\mathrm{Cl})$ & 1 & $1.5(0.6-3.9)$ & $1.7(0.7-4.0)$ & \\
\hline \multirow{2}{*}{$\begin{array}{l}\text { Use of lipid lowering } \\
\text { medication }\end{array}$} & $(\%)$ & 14.1 & 17.8 & 25.9 & 574 \\
\hline & OR (Cl) & 1 & $1.3(0.7-2.2)$ & $1.9^{*}(1.2-3.1)$ & \\
\hline
\end{tabular}

- OR significantly different from NGT; Data are given as percentages and as OR $(\mathrm{Cl})$. 
Table 13: Percentage and Odds Ratio (OR) with confidence interval $(\mathrm{CI})$ in parentheses of cardiovascular disease, cardiovascular events and preventive surgery according to glucose tolerance status in the CODAM study, adjusted for age and gender.

\begin{tabular}{|c|c|c|c|c|c|}
\hline & & $\begin{array}{c}\text { NGT } \\
(\mathrm{N}=298)\end{array}$ & $\begin{array}{c}\text { IGT } \\
(\mathrm{N}=104)\end{array}$ & $\begin{array}{c}\mathrm{DM} \\
(\mathrm{N}=147)\end{array}$ & $\mathrm{N}$ \\
\hline \multirow[t]{2}{*}{ Coronary heart disease } & $(\%)$ & 16.9 & 22.2 & 20.0 & 566 \\
\hline & OR (CI) & 1 & $1.4(0.8-2.3)$ & $1.0(0.6-1.8)$ & \\
\hline \multirow[t]{2}{*}{ Cardiovascular disease } & $(\%)$ & 20.1 & 26.6 & 25.7 & 557 \\
\hline & OR (CI) & 1 & $1.4(0.8-2.3)$ & $1.2(0.7-1.9)$ & \\
\hline \multirow[t]{2}{*}{ Prior myocardial infarction } & $(\%)$ & 7.5 & 9.3 & 7.5 & 570 \\
\hline & OR (Cl) & 1 & $1.2(0.6-2.6)$ & $0.8(0.4-1.8)$ & \\
\hline \multirow{4}{*}{$\begin{array}{l}\text { Serious heart disease } \\
\text { other than MI } \\
\text { Stroke or brain hemorrhage }\end{array}$} & $(\%)$ & 9.2 & 10.2 & 9.7 & 564 \\
\hline & OR $(\mathrm{Cl})$ & 1 & $1.1(0.5-2.2)$ & $0.9(0.5-1.8)$ & \\
\hline & $(\%)$ & 3.4 & 4.8 & 5.5 & 561 \\
\hline & OR (CI) & 1 & $1.4(0.5-3.8)$ & $1.4(0.5-3.7)$ & \\
\hline \multirow{2}{*}{$\begin{array}{l}\text { Documented peripheral } \\
\text { artery disease }\end{array}$} & $(\%)$ & 6.9 & 11.3 & 13.9 & 557 \\
\hline & OR (Cl) & 1 & $1.6(0.8-3.6)$ & $1.8(0.9-3.6)$ & \\
\hline \multirow{2}{*}{$\begin{array}{l}\text { Narrowed blood vessels } \\
\text { of the viscera or legs }\end{array}$} & $(\%)$ & 3.4 & 4.7 & 6.9 & 565 \\
\hline & OR $(\mathrm{Cl})$ & 1 & $1.3(0.5-3.7)$ & $1.7(0.7-4.3)$ & \\
\hline \multirow[t]{2}{*}{ Bypass surgery } & $(\%)$ & 3.7 & 3.9 & 4.8 & 571 \\
\hline & OR $(\mathrm{Cl})$ & 1 & $1.0(0.4-3.0)$ & $1.0(0.4-2.8)$ & \\
\hline \multirow{2}{*}{$\begin{array}{l}\text { Percutaneous transluminal } \\
\text { balloon dilation (PTCA) }\end{array}$} & $(\%)$ & 6.4 & 5.5 & 4.8 & 571 \\
\hline & $\mathrm{OR}(\mathrm{Cl})$ & 1 & $0.8(0.3-2.0)$ & $0.6(0.3-1.6)$ & \\
\hline \multirow[t]{2}{*}{ Operation of blood vessels } & $(\%)$ & 1.3 & 3.1 & 4.1 & 571 \\
\hline & OR (CI) & 1 & $2.3(0.6-9.4)$ & $2.9(0.8-10.6)$ & \\
\hline \multirow{2}{*}{$\begin{array}{l}\text { History of coronary } \\
\text { angiography }\end{array}$} & $(\%)$ & 8.1 & 11.8 & 13.6 & 571 \\
\hline & OR (Cl) & 1 & $1.5(0.7-3.0)$ & $1.5(0.8-2.9)$ & \\
\hline \multirow[t]{2}{*}{ Pacemaker } & $(\%)$ & 0 & 0 & 0 & 570 \\
\hline & OR $(\mathrm{Cl})$ & - & - & - & \\
\hline
\end{tabular}

- OR significantly different from NGT; Data are given as percentages and as $\mathrm{OR}(\mathrm{CI}) ; \mathrm{MI}=$ myocardial infarction

The European Society of Hypertension recently recognized that secondary organ involvement, i.e. target organ damage, could act as a risk factor for cardiovascular risk on its own (22). Target Organ Damage (TOD) was defined as follows: intima-media thickness (IMT) $>0.90 \mathrm{~mm}$, microalbuminuria $>20 \mathrm{mg} / \mathrm{L}$ (23), left ventricular hypertrophy either as Sokolow-Lyons index without the presence of a bundle branch block (SV1 + RV5 or $6>38 \mathrm{~mm}$ ), or Cornell voltage QRS duration product $>2440$ mm*ms $(50,51)$, or when the ECG was coded 3.1 or 3.3 according to Minnesota, and serum creatinine in men $>115 \mu \mathrm{mol} / \mathrm{l}$ and in women $>107 \mu \mathrm{mol} / \mathrm{l}(22)$. We extended the criteria for vessel wall damage (IMT) by adding criteria for endothelial dysfunction and peripheral vascular disease (PVD). Endothelial dysfunction, of which plasma soluble intercellular adhesion molecule (sICAM) concentrations is a marker $(37,38)$, was considered present when plasma sICAM concentrations exceeded the 90th percentile determined in NGT subjects, i.e. $450 \mathrm{ng} / \mathrm{mL}$. PVD was considered present when the $A B I$ was below $0.90(15,16)$. Significantly more target organ damage of peripheral vascular disease and microalbuminuria was found in DM subjects, i.e. more damage of the large vessels and kidneys was present in DM subjects compared to IGT 
and NGT subjects (Table 14). A more detailed description of these results will be given in Chapter 6.

Table 14: Percentage and Odds Ratio (OR) with confidence interval $(\mathrm{Cl})$ in parentheses of glucose tolerance of Target Organ Damages defined by the European Society of Hypertension (27), adjusted for age and gender.

$\begin{array}{cccc}\begin{array}{c}\text { NGT } \\ (\mathrm{N}=298)\end{array} & \text { IGT } & \text { DM } & \mathrm{N} \\ (\mathrm{N}=104) & (\mathrm{N}=147) & \end{array}$

\section{Vessel wall}

TOD-IMT

TOD-PVD

TODSICAM

Heart

TOD-LVH

$\begin{array}{lc}(\%) & 20.5 \\ \text { OR }(C l) & 1\end{array}$

$\begin{array}{lc}(\%) & 10.9 \\ \text { OR }(\mathrm{Cl}) & 1 \\ (\%) & 2.0 \\ \text { OR }(\mathrm{Cl}) & 1 \\ (\%) & 10.1 \\ \text { OR }(\mathrm{Cl}) & 1\end{array}$

12.4
$1.1(0.5-2.2)$
3.1
$1.8(0.5-6.5)$
11.6
$1.2(0.6-2.4)$

11.8
$0.9(0.5-1.8)$
9.0
$\mathbf{4 . 3}^{*}(1.6-11.7)$
17.1
$2.0^{*}(1.1-3.6)$

\section{4}

$1.1(0.5-2.3)$

25.5

$1.2(0.6-2.6)$

245

499

568

573

r

\section{Kidneys}

TOD-CREAT

(\%)

$\mathrm{OR}(\mathrm{Cl})$

TOD-MA
(\%)

OR (Cl)

$$
0.3
$$

5.8
0

6.7
2.1

$4.5(0.5-45.0)$

21.0
573

432

- OR significantly different from NGT; Data are given as percentages and as OR (CI); TOD-IMT = target organ damage defined according to intima-media thickness (IMT $>0.90 \mathrm{~mm}$ ); TOD-PVD $=$ target organ damage defined according to the presence of peripheral vascular disease $(A B I<0.90)$; TOD-SICAM $=\operatorname{target}$ organ damage defined according to the concentration of plasma soluble intercellular adhesion molecule (conc $<450 \mathrm{ng} / \mathrm{mL}$ ); TOD-LVH = target organ damage defined according to the presence of left ventricular hypertrophy (Minnesota code 3.1 or 3.3, or Sokolow - Lyons index without the presence of a bundle branch block (SV1 + RV5 or $6>38 \mathrm{~mm}$ ), or Cornell voltage QRS duration product $>2440 \mathrm{~mm} * \mathrm{~ms}$ ); TOD-CREAT = target organ damage defined according to concentration of plasma creatinine (concentration creatinine men: $>115 \mu \mathrm{mol} /$; ; women $>107 \mu \mathrm{mol} / \mathrm{l})$; TOD-MA = target organ damage defined according to the presence of microalbuminuria (concentration albumin $>20 \mathrm{mg} / \mathrm{L}$ ).

These results combined indicate that hyperglycemia is preceded by abnormalities in cholesterol, triglycerides, FFA and insulin, as well as increased body fatness, more abdominal obesity, and increased subcutaneous fat. Furthermore, blood pressure was significantly higher and peripheral vascular disease and early renal damage, indicated by Ankle/Brachial Index and microalbuminuria, is found in DM subjects. In agreement with these results, target organ damage as defined by the European Society of Hypertension (22) was already significantly more present in DM subjects, i.e. on the level of the large vessels and kidneys. Other indicators of cardiovascular disease that we found in DM subjects were conduction disturbances of the heart and metabolic stress, indicated by increased heart rate and QRS duration, but not heart rate corrected QT time. Also, increased arterial stiffness was found in DM subjects, as well as increased soluble ICAM and CRP. Although corrected QT-time and a similar IMT 
suggest that subjects with recently diagnosed DM are not at increased risk for CVD, the other variables certainly indicate that they are, and that even some form of CVD is already present, such as peripheral vascular disease and renal damage. A possible explanation for normal QTc time and IMT may be that these variables appear abnormal only when diabetes is of longer duration. Therefore, we conclude that subjects recently diagnosed with DM are already at increased risk for CVD and even show some vascular damage which is mostly due to, or associated with, metabolic abnormalities.

\section{5: Description of Impaired Glucose Tolerance (IGT) and Impaired Fasting Glucose (IFG)}

In total, 104 subjects with IGT and 25 subjects with IFG participated in the CODAM study. In the IGT group, 58 men and 46 women were included with mean age of $59.5 \pm$ 6.7 years and BMI of $28.9 \pm 4.1 \mathrm{~kg} / \mathrm{m}^{2}$. In the IFG group, 19 men and 6 women with a mean age of $59.1 \pm 7.3$ years and BMI of $28.9 \pm 4.5 \mathrm{~kg} / \mathrm{m}^{2}$ were included. In most populations, IGT is considerably more prevalent than IFG $(52,53)$. In agreement with this, we found that, in the screening phase of the present study, the prevalence of IGT was almost twice that of IFG, 14.2 versus $7.9 \%$ respectively (3). The prevalence of IGT is reported to be higher in women than men in all age groups except over the age of 60 in Asian populations and over the age of 80 in European (53). However, we found more men than women with IGT in the CODAM study $(55.8 \%)$, although the percentage men was lower in the screening phase $(49.1 \%)$. One possibility is that this is caused by selection bias, because subjects who were defined IFG in the screening phase were not invited for the CODAM study. However, IFG is reported to be more common in men than women in virtually all age groups, typically one-and-a-half to three times higher, but up to seven or eight times higher in Europeans aged $50-70$ years (53). In both the screening phase and in the CODAM study, most subjects with IFG were male $(61.2 \%$ and $76.0 \%$ respectively).

Both impaired glucose tolerance (IGT) and impaired fasting glucose (IFG) are very strong risk markers for the development of diabetes (53). In type 2 diabetes, impaired insulin action, insulin secretory dysfunction, and increased endogenous glucose output are present. IGT is particularly associated with peripheral insulin resistance, mostly at the level of the skeletal muscle, which is characterized by elevated post-load glucose (53). During an OGTT, the normal response to the absorption of the carbohydrate load is both to suppress hepatic glucose output and to enhance glucose uptake in the muscle and liver. This requires a prompt increase in insulin secretion, and adequate hepatic and muscle sensitivity to insulin. Therefore, impaired insulin action and insulin secretory dysfunction are already present in IGT. IFG on the contrary, is predominantly characterized by abnormalities of the metabolic functions that control fasting glucose (53). Normal control of fasting glucose depends on the ability to maintain adequate basal insulin secretion, as well as on an appropriate degree of insulin sensitivity in the liver to control hepatic glucose output. Increased hepatic glucose output thus probably contributes to the mildly elevated fasting glucose concentrations in IFG. Therefore, IGT and IFG have a different etiology.

There is still some controversy whether subjects with IGT and IFG differ in anthropometric or other metabolic characteristics. A study in non-diabetic Pima Indians 
showed that subjects with IFG were heavier, had a larger percent body fat, fat mass and fat-free mass than those with IGT (54). The Botnia Study from Finland showed that subjects with IFG had a higher WHR, triglycerides, and total cholesterol, and a lower HDL cholesterol than subjects with IGT (55). The RIAD study (56) and the Paris Prospective Study (57) found lower FFA levels in IFG subjects but did not find other metabolic differences. In contrast to the study of the Pima Indians and the Botnia study, the present study found, after adjustment for age and gender, a significantly lower WHR and concentration triglycerides and no differences in cholesterol in IFG compared to IGT subjects (Table 15). We also found significantly lower free fatty acids and fasting plasma insulin concentrations in IFG subjects compared to IGT subjects which was in agreement with the RIAD study (56) and the Paris Prospective Study (57). In addition, we found one of the inflammation sensitive proteins, $\mathrm{C} 3$, to be significantly lower in IFG subjects compared to IGT subjects.

Although some data suggest that IGT is more strongly associated with hypertension and dyslipidemia than IFG (53), no differences were found in the presence of hypertension between IGT and IFG in the present study (Table 15). However, the use of antihypertensive medication was significantly higher in IGT subjects (Table 13). Betablockers were significantly more used by subjects with IGT $(28.8 \%$ versus $4.0 \%$ respectively in subjects with IFG). There were no differences in the use of lipid lowering medication. Furthermore, significantly more CHD and CVD was reported by IGT subjects, $26.5 \%$ and $32.0 \%$ respectively versus $4.2 \%$ and $4.2 \%$ respectively by IFG subjects, which was caused by the fact that only prior myocardial infarction and PTCA were reported by IFG subjects while all disorders that were included in the definition of CHD and CVD were reported by IGT subjects. Little data are available about the relationship between IGT and IFG with CVD, but in unadjusted analyses both IFG and IGT were found to be associated with CVD and total mortality (53). When considering target organ damage (22), no differences were found (data not shown).

In conclusion, the differences that exist between IGT and IFG are not fully elucidated yet. IGT subjects appear to have higher levels of risk factors for CVD and type 2 diabetes and have more self-reported CVD and CHD compared to IFG subjects. However, our cross-sectional data can not fully explain what this means. Therefore, more prospective research is needed to elucidate the possible different roles that IGT and IFG play in the development of both type 2 diabetes and CVD. The number of IFG subjects was rather small in comparison with the number of IGT subjects in the present CODAM study, and differences were only present in a small number of variables. This may have been caused by the fact that the IFG subjects in the CODAM study were diagnosed as IGT subjects in the preceding screening. Therefore, we decided to treat both groups as one in all analyses presented in this thesis. 
Table 15: Variables different between impaired glucose tolerance (IGT) and impaired fasting glucose (IFG) in the CODAM study, adjusted for age and gender.

\begin{tabular}{|c|c|c|c|}
\hline & $\begin{array}{c}\text { IFG } \\
(N=25)\end{array}$ & $\begin{array}{c}\text { IGT } \\
(\mathrm{N}=104)\end{array}$ & p-value \\
\hline Age (years) & $\begin{array}{c}59.2 \\
(56.5-61.9)\end{array}$ & $\begin{array}{c}59.4 \\
(58.1-60.8)\end{array}$ & NS \\
\hline Body Mass Index $\left(\mathrm{kg} / \mathrm{m}^{2}\right)$ & $\begin{array}{c}29.0 \\
(27.3-30.6)\end{array}$ & $\begin{array}{c}28.9 \\
(28.1-29.7)\end{array}$ & NS \\
\hline Waist-to-Hip Ratio & $\begin{array}{c}0.934 \\
(0.911-0.956)\end{array}$ & $\begin{array}{c}0.958 \\
(0.947-0.969)\end{array}$ & 0.041 \\
\hline Fasting glucose (mmol/L) & $\begin{array}{c}6.3 \\
(6.1-6.5)\end{array}$ & $\begin{array}{c}5.8 \\
(5.7-5.9)\end{array}$ & $<0.001$ \\
\hline $\begin{array}{l}\text { Glucose conc } 2 \mathrm{~h} \\
\text { (mmo//L) }\end{array}$ & $\begin{array}{c}5.9 \\
(5.4-6.3)\end{array}$ & $\begin{array}{c}9.2 \\
(9.0-9.4)\end{array}$ & $<0.001$ \\
\hline Triglycerides " (mmol/ ) & $\begin{array}{c}1.20 \\
(0.50-3.00)\end{array}$ & $\begin{array}{c}1.65 \\
(0.50-4.10)\end{array}$ & 0.036 \\
\hline $\begin{array}{l}\text { Total cholesterol } \\
(\mathrm{mmol} / \mathrm{L})\end{array}$ & $\begin{array}{c}5.20 \\
(4.81-5.59)\end{array}$ & $\begin{array}{c}5.33 \\
(5.14-5.52)\end{array}$ & NS \\
\hline $\mathrm{HDL}$-cholesterol (mmol/L) & $\begin{array}{c}1.24 \\
(1.12-1.37)\end{array}$ & $\begin{array}{c}1.14 \\
(1.08-2.10)\end{array}$ & NS \\
\hline Free fatty acids (mmol/L) & $\begin{array}{c}0.46 \\
(0.39-0.53)\end{array}$ & $\begin{array}{c}0.57 \\
(0.54-0.61)\end{array}$ & 0.013 \\
\hline Fasting insulin" (pmol/L) & $\begin{array}{c}49.0 \\
(25.0-153.0)\end{array}$ & $\begin{array}{c}70.0 \\
(18.0-279.0)\end{array}$ & 0.006 \\
\hline $\begin{array}{l}\text { Complement factor } 3 \\
(\mathrm{~g} / \mathrm{L})\end{array}$ & $\begin{array}{c}1.69 \\
(1.57-1.82)\end{array}$ & $\begin{array}{c}1.92 \\
(1.86-1.98)\end{array}$ & 0.001 \\
\hline
\end{tabular}

\begin{tabular}{|c|c|c|c|}
\hline Hypertension (\%) & 64.0 & 69.2 & $1.4(0.6-3.7)$ \\
\hline $\begin{array}{l}\text { Antihypertensive } \\
\text { medication (\%) }\end{array}$ & 20.0 & 45.2 & $3.4^{*}(1.2-9.9)$ \\
\hline $\begin{array}{l}\text { Use of lipid lowering } \\
\text { medication (\%) }\end{array}$ & 8.0 & 20.2 & $2.9(0.6-13.3)$ \\
\hline $\mathrm{CHD}(\%)$ & 4.2 & 26.5 & $10.2^{*}(1.3-81.5)$ \\
\hline CVD (\%) & 4.2 & 32.0 & $12.9^{*}(1.6-101.4)$ \\
\hline
\end{tabular}

\section{References}

1. Van Dam RM, Grievink L, Ocke MC, Feskens EJ. Patterns of food consumption and risk factors for cardiovascular disease in the general Dutch population. Am J Clin Nutr 2003; 77:1156-63

2. Seidell JC, Verschuren WMM, Kromhout D. Prevalence and trend of obesity in The Netherlands 1987-1991. Int J Obes 1995; 19: 924927 
3. Mensink M, Corpeleijn E, Feskens EJM, Kruijshoop M, Saris WHM, de Bruin TWA, Blaak EE: Study on lifestyle-intervention and impaired glucose tolerance Maasticht (SLIM): design and screening results. Diabetes Res Clin Pract 2003; 61:49-58

4. Wendel-Vos W, Schuit J, Kromhout D, Saris W. Reproduceerbaarheid en validiteit van een korte vragenlijst over lichamelijke activiteit. Poster 18.4 WEON 2000

5. Rose GA. The diagnosis of ischaemic heart pain and intermittent claudication in field surveys. Bull Wid Hith Org 1962; 27: 645-658

6. Cook DG, Shaper AG, MacFarlane PW. Using the WHO (Rose) Angina Questionnaire in cardiovascular epidemiology. Int J Epidemiol 1989; 18: 607-613

7. Grootenhuis PA, Snoek FJ, Heine RJ, Bouter LM. Development of a type 2 diabetes symptom checklist: a measure of symptom severity. Diabet Med 1994; 11: 253-261

8. Aaronson NK, Muller M, Cohen PDA, Essink-Bot M-L, Fekkes M, Sanderman R, Sprangers MAG, te Velde A, Verrips E. Translation, validation, and norming of the Dutch language version of the SF. 36 Health Survey in community and chronic disease populations. J Clin Epidemiol 1998; 51: 10551068

9. Beekman ATF, Deeg DJH, van Limbeek J, Braam AW, de Vries MZ, van Tilburg W. Criterion validity of the Center for Epidemiologic Studies Depression scale (CES-D): results from a community-based sample of older subjects in the Netherlands. Psych Med 1997; 27: 231-235

10. Ocké MC, Bueno-De-Mesquita HB, Goddijn HE, Jansen A, Pols MA, van Staveren WA, Kromhout D. The Dutch EPIC Food Frequency Questionnaire. I. Description of the questionnaire, and relative validity and reproducibility for food groups. Int J Epidiol 1997; 26 (suppl 1): S37-S48

11. World Health Organization: Definition, diagnosis and classification of diabetes mellitus and its complications. Report of a WHO Consultation. Part 1: Diagnosis and classification of diabetes mellitus. WHO Technical Report Series 1999: 1-59

12. Friedewaid WT, Levy R, Fredrickson DS. Estimation of concentration of LDL cholesterol without the use of preparative ultracentrifuge. Clin Chem 1972; 18; 499

13. Durnin JV. Womersley J: Body fat assessed from total body density and its estimation from skinfold thickness: measurements on 481 men and women aged from 16 to 72 years. Br J Nutr 1974; 32: 77-97

14. The sixth report of the Joint National Committee on prevention, detection, evaluation, and treatment of high blood pressure. Arch Intern Med 1997; 157: 2413-2446

15. Schroll M, Munck O. Estimation of peripheral arteriosclerotic disease by ankle blood pressure measurements in a population study of 60-year-old men and women. J Chron Dis 1981; 34: 261269

16. Fowkes FGR, Housley E, Cawood EHH, Macintyre CCA, Ruckley CV, Prescott RJ. Edinburgh Artery Study: Prevalence of asymptomatic and symptomatic peripheral arterial disease in the general population. Int J Epidemiol 1991; 20: 384-392

17. Christensen PK, Gall MA, Major-Pedersen A, Sato A, Rossing P, Breum L, Pietersen A, Kastrup J, Parving HH. OTc interval length and QT dispersion as predictors of mortality in patients with non insulin-dependent diabetes. Scand J Clin Lab Invest 2000; 60: 323-332

18. Dekker JM, Schouten EG, Klootwijk P, Pool J, Kromhout D. Association between QT interval and coronary heart disease in middle-aged and elderly men. The Zutphen Study. Circulation 1994; 90 : 779-785

19. De Bruyne MC, Hoes AW, Kors JA, Hofman A, van Bemmel JH, Grobbee DE. Prolonged QT interval predicts cardiac and all-cause mortality in the elderly. Eur Heart J 1999; 20: 278-284

20. Vanninen E, Unsitupa MI, Lansimies. Ventricular repolarization is correlated with metabolic control in newly diagnosed type 2 diabetes. Clin Physiol 1996; 16: 449-461

21. Rose GA, Blackburn $\mathrm{H}$ Cardiovascular survey methods. World Health Organization Monograph Series 1968; No. 56, World Health Organization, Geneva

22. European Society of Hypertension-European Society of Cardiology guidelines for the management of arterial hypertension. J Hypertens 2003; 21: 1011-1053 
23. Marshall SM: Screening for microalbuminuria: Which measurement? Diabet Med 1990; 8: 706-711

24. Bots ML, Dijk JM, Oren A, Grobbee DE (2002) Carotid intima-media thickness, arterial stiffness and risk of cardiovascular disease: current evidence. J Hypertens 20: 2317-2325

25. Safar ME, Laurent S, Pannier BM, London GM (1987) Structural and functional modifications of peripheral large arteries in hypertensive patients. J Clin Hypertens 3: 360-367

26. Hirai T, Sasayama S, Kawasaki T, Yagi S (1989) Stiffness of systemic arteries in patients with myocardial infarction. a noninvasive method to predict severity of coronary atherosclerosis. Circulation 810: 78-86

27. Simons PCG, Algra A, Bots ML, Grobbee DE, van der Graaf Y (1999) Common carotid intimamedia thickness and arterial stiffness. Indicators of cardiovascular risk in high-risk patients. The SMART study (Second Manifestations of ARTerial disease). Circulation 100:951-957

28. Keulen ET, Kruijshoop M, Schaper NC, Hoeks AP, de Bruin TWA: Increased intima-media thickness in familial combined hyperlipidemia associated with apolipoprotein B. Arterioscler Thromb Vasc Biol 2002; 22: 283-288

29. Brands PJ, Hoeks AP, Willigers J, Willekes C, Reneman RS: An integrated system for the noninvasive assessment of vessel wall and hemodynamic properties of large arteries by means of ultrasound. Eur J Ultrasound 1999 ; 9: 257-266

30. Van Bortel LM, Duprez D, Starmans-Kool MJ, et al.: Clinical applications of arterial stiffness, Task Force III: recommendations for user procedures. Am J Hypertens 2002; 15: 445-452

31. Howard BV. Lipoprotein metabolism in diabetes mellitus. J Lipid Res 1987; 28: 613-628

32. Felber J-P, Golay A: Pathways from obesity to diabetes. Int J Obes 2002; 26 suppl 2: S39-S45

33. Adler A: Obesity and target organ damage: diabetes. Int J Obes 2002; 26 suppl 4; S11-S14

34. Temelkova-Kurktschiev TS, Koehler C, Leonhardt W, et al. (1999) Increased intimal-medial thickness in newly detected type 2 diabetes: risk factors. Diabetes Care 22: 333-338

35. Bonora E, Tessari R, Micciolo R, et al. (1997) Intimat-medial thickness of the carotid artery in nondiabetic and NIDDM patients. Relationship wth insulin resistance. Diabetes Care 20: 627-631

36. Becker A, van Hinsbergh WW, Jager A, Kostense PJ, Dekker JM, Nijpels G, Heine RJ, Bouter LM, Stehouwer $\mathrm{CD}$. Why is soluble intercellular adhesion molecule-1 related to cardiovascular mortality? Eur J Clin Invest 2002; 32: 1-8

37. Caballero AE, Arora S, Saouaf R, Lim SC, Smakowski P, Park JY, King GL, LoGerfo FW, Horton ES, Veves A. Microvascular and macrovascular reactivity is reduced in subjects at risk for type 2 diabetes. Diabetes 1999; 48: 1856-1862

38. Rhode LEP. Hennekens CH, Ridker PM. Cross-sectional study of soluble intercellular adhesion molecule-1 and cardiovascular risk factors in apparently healthy men. Arterioscler Thromb Vasc Biol 1999; 19: 1595-1599

39. Guerrero-Romero F, Rodriguez-Moran M. Relation of C-reactive protein to features of the metabolic syndrome in normal glucose tolerant, impaired glucose tolerant, and newly diagnosed type 2 diabetic subjects. Diabetes Metab 2003; 29: 65-71

40. Thorand B, Lowel H, Schneider A, Kolb H, Meisinger C, Frohlich M, Koenig W. Creactive protein as a predictor for incident diabetes mellitus among middle-aged men: results from the MONICA Augsburg cohort study, 1984-1998. Arch Intern Med 2003; 163: 93-99

41. Ridker PM, Buring JE, Cook NR, Rifai N. Greactive protein, the metabolic syndrome, and risk of incident cardiovascular events. An \&-year follow -up of 14719 initially healthy American women. Circulation 2003; 107: 391-397

42. Weyer C, Yudkin JS, Stehouwer CDA, Schalwijk CG, Pratley RE, Tataranni PA. Humoral markers of inflammation and endothelial dysfunction in relation to adiposity and in vivo insulin action in Pima Indians. Atherosclerosis 2002; 161: 233-242

43. Adler Al, Stevens RJ, Manley SE, Bious RW, Cull CA, Holman RR; UKPDS Group. Development and progression of nephropathy in type 2 diabetes: the United Kingdom Prospective Diabetes Study (UKPDS 64). Kidney Int 2003; 63: 225-232

44. Alcolado JC, Laji K. Gill-Randall R. Maternal transmission of diabetes. Diabet Med 2002; 19: $89-98$ 
45. Karter AJ, Rowell SE, Ackerson LM, Mitchell BD, Ferrara A, Selby JV, Newman B. Excess maternal transmission of type 2 diabetes. The Northem California Kaiser Permanente Diabetes Registry. Diabetes Care 1999; 22: 938-943

46. De Silva SNT, Weerasuriya N, De Alwis NMW, DeSilva MWA, Fernando DJS. Excess maternal transmission and familial aggregation of type 2 diabetes in Sri Lanka. Diabetes Res Clin Pract 2002; 58: 173-177

47. Simonson DC. Etiology and prevalence of hypertension in diabetic patients. Diabetes Care 1988; 11: $821-827$

48. Expert Panel on Detection, Evaluation, and Treatment of High Blood Cholesterol in Adults. Executive Summary of The Third Report of The National Cholesterol Education Program (NCEP) Expert Panel on Detection, Evaluation, and Treatment of High Blood Cholesterol In Adults (Adult Treatment Panel III). JAMA 2001; 285: 2486-2497

49. Pyörălă K, Laakso M, Uusitupa M. Diabetes and atherosclerosis: an epidemiologic review. Diabetes Metab Rev 1987; 3: 463-524

50. Sokolow M, Lyon TO. The ventricular complex in left ventricular hypertrophy as obtained by unipolar precordial and link leads. Am Heart J 1949; 37: 161-186

51. Molloy TJ, Okin PM, Devereux RB, Kligfield P. Electrocardiographic detection of left ventricular hypertrophy by the simple QRS voltage-duration product. J Am Coll Cardiol 1992; 20: 1180-1186

52. Tripathy D, Cartsson M, Almgren P, Isomaa B, Taskinen MR, Tuomi T, Groop LC. Insulin secretion and insulin sensitivity in relation to glucose tolerance. Lessons from the Botnia Study. Diabetes 2000; 49: 975-980

53. Unwin N, Shaw J, Zimmet P, Alberti KGMM. Impaired glucose tolerance and impaired fasting glycaemia: the current status on definition and intervention. Diabet Med 2002; 19: 708-723

54. Weyer C, Bogardus C, Pratley R. Metabolic characteristics of individuals with impaired fasting glucose and/or impaired glucose tolerance. Diabetes 1999; 48: 2197-2203

55. Hanefeld M, Temelkova-Kurktschiev T, Schaper F, Henkel E, Siegert G, Koehler C. Impaired fasting glucose is not a risk factor for atherosclerosis. Diabet Med 1999; 16: 212-218

56. Hanefeld M, Koehler C, Fuecker K, Henkel E, Schaper F, Temelkova-Kurktschiev T. Insulin secretion and insulin sensitivity pattern is different in isolated impaired glucose tolerance and impaired fasting glucose. The Risk Factor in Impaired Glucose Tolerance for Atherosclerosis and Diabetes Study. Diabetes Care 2003; 26: 686-674

57. Charles MA, Fontbonne A, Thibult N, Warnet J, Rosselin GE, EschwegeE. Risk factors for NIDDM in white population. Diabetes 1991; 40: 796-799 
APPENDICES WITH CHAPTER 2 


\section{6: Appendix 'Letter of invitation for the screening of the SLIM and CODAM studies'}

\section{Onderzoek naar faktoren die een rol spelen bij het ontstaan van suikerziekte}

Aan geadresseerde,

Datum poststempel

Geachte mevrouw, meneer,

In het voorjaar van 1998 heeft u meegewerkt aan een onderzoek van de GGD en het RIVM. Hiervoor heeft u een korte vragenlijst ingevuld en een test gedaan met een urinestrip. U gaf verder aan accoord te gaan in de toekomst benaderd te worden voor aanvullend onderzoek. Voor aanvullend onderzoek op het gebied van diabetes mellitus (suikerziekte) willen wij nu graag uw medewerking vragen.

Diabetes mellitus type 2 (ouderdoms-suikerziekte) is een veel voorkomende aandoening. Naar schatting lijden zo'n 300.000 Nederlanders hieraan. De ziekte gaat gepaard met een verhoogd risico op allerlei complicaties, zoals aandoeningen van hart en vaten, ogen en nieren. Overgewicht is één van de belangrijke oorzaken, maar daarnaast spelen nog een groot aantal andere risicofactoren een rol, waaronder het voorkomen van suikerziekte in de familie en te weinig beweging. Om diabetes en bijbehorende complicaties te bestrijden is echter meer kennis nodig over hoe deze factoren precies werken en op wat voor manier we het optreden van diabetes kunnen uitstellen of voorkomen.

In samenwerking met de Universiteit Maastricht en het Academisch Ziekenhuis Maastricht zijn wij onlangs gestart met een grootschalig onderzoek op dit gebied, onder andere gesteund door het Diabetes Fonds Nederland. In 1999 nodigen we een deel van de mensen uit die, net als $u$, al eerder aan het onderzoek van de GGD en RIVM hebben meegedaan. Wij hopen van harte dat u meedoet.

Ook als uw gezondheid niets te wensen overlaat, is uw deelname belangrijk! 


\section{Wat houdt het onderzoek voor $u$ in?}

Op de dag van het onderzoek brengt u op een afgesproken tijdstip ('s ochtends) een bezoek aan het Academisch Ziekenhuis Maastricht. Het is de bedoeling dat $\mathrm{u}$ nuchter naar het ziekenhuis komt. Dit houdt in dat $u$ de dag voor het onderzoek vanaf 22.00 uur niets meer mag eten en niets anders mag drinken dan water.

Er zal aan u gevraagd worden een korte vragenlijst in te vullen en er zal een glucose tolerantie test bij u worden afgenomen. Aan het begin van de test wordt met behulp van een vingerprik uw nuchtere bloedsuikergehalte bepaald. Daarna krijgt u een suikerdrank te drinken. Vervolgens wordt nog 2 keer uw bloedsuikergehalte bepaald (1 uur en 2 uur na het drinken van de suikerdrank).

De glucose tolerantie test geeft aan in hoeverre uw bloedsuiker te hoog is en of er mogelijk sprake is van diabetes. Aan de hand van de uitslag kunt u mogelijk gevraagd worden om mee te doen aan een vervolgonderzoek. $U$ hoeft op dit moment echter nog niet te beslissen of $u$ daar aan mee zou willen doen.

Op bijgevoegd antwoordkaartje kunt $\mathrm{u}$ aangeven of $\mathrm{u}$ bereid bent om mee te werken aan het onderzoek. Als $u$ aangeeft mee te willen werken, wordt $u$ binnen een maand gebeld door iemand van de Universiteit Maastricht voor een afspraak.

Belangrijk om te weten is dat het onderzoek zal lopen tot het einde van dit jaar. Indien $\mathrm{u}$ op dit moment verhinderd bent tot deelname -door vakantie of ziekte- is het dus ook mogelijk in de loop van de komende maanden deel te nemen. In dat geval willen we u vragen op het kaartje aan te geven wanneer we met u contact kunnen opnemen voor het maken van een afspraak. Wilt $u$ het antwoordkaartje liefst binnen twee weken ingevuld retourneren? ( $U$ hoeft geen postzegel te plakken).

Mocht u nu al vragen hebben, dan kunt u nadere informatie krijgen bij

Mw. T. Hermans en Mw. I. Nijs van de Universiteit Maastricht, tel 043-3881638.

Met vriendelijke groet,

Drs H. de Munter, GGD Maastricht 


\section{7: Appendix 'Participation form for the screening of the SLIM and CODAM studies'}

Ik ben wel / niet bereid om mee te doen aan het onderzoek (svp doorstrepen wat niet van toepassing is)

Ik ben telefonisch bereikbaar (s.v.p. bij alle dagen doorstrepen wat niet van toepassing is)
Maandag ochtend/middag : op het werk / thuis
Dinsdag ochtend/middag : op het werk / thuis
Woensdag ochtend/middag : op het werk / thuis
Donderdag ochtend/middag : op het werk / thuis
Vrijdag ochtend/middag : op het werk / thuis

Mijn telefoonnummer op het werk is

Mijn telefoonnummer thuis is

Indien u telefonisch niet bereikbaar bent, wilt $\mathrm{u}$ dan zelf 's ochtends bellen naar: van het Onderzoeksteam Diabetes aan de Universiteit Maastricht. 


\section{8: 'Letter of invitation for participation in the CODAM study for NGT subjects'}

Aan geadresseerde,

Geachte heer/mevrouw,

Enige tijd geleden heeft u de uitslag ontvangen van het Diabetes Onderzoek Maastricht van het Academisch Ziekenhuis Maastricht in samenwerking met het RIVM en de GGD. Uit de uitslagen van de vingerprik nuchter en de vingerprik na de suikerdrank bleek dat u geen suikerziekte heeft. Verder heeft u aangegeven geen bezwaar te hebben voor deelname aan een vervolgonderzoek.

Eén van de vervolgonderzoeken die door het Academisch Ziekenhuis Maastricht in samenwerking met de Universiteit Maastricht wordt uitgevoerd is een zogenaamde 'volg'- of cohortstudie. Bij dit onderzoek worden een aantal metingen herhaald om zo te bepalen welke risicofactoren van diabetes (suikerziekte) en atherosclerose (aderverkalking) in de loop van de tijd veranderen. Hieruit kan afgeleid worden welke factoren voorspellend zouden kunnen zijn voor het ontstaan van diabetes en atherosclerose en welke factoren juist beschermen. Voor deze cohortstudie willen wij nu graag uw medewerking vragen.

Bij deze brief is een informatiebrochure gevoegd. Wij willen u vragen deze aandachtig door te lezen. Indien u aan het onderzoek wilt deelnemen willen wij u vragen ons zo spoedig mogelijk te bellen op tel. nr: (043) 3881638 om een afspraak te maken. Ook wanneer u nog vragen heeft bent $u$ vrij ons te bellen op dit telefoonnummer.

Bij voorbaat dank,

Drs. M. Kruijshoop

mede namens de overige leden van het Onderzoeksteam Diabetes:

Drs. M.R. Mensink

Mw. T.J.F. M.B. Hermans

Mw. I. Nijs

Dr. E.E. Blaak

Prof. Dr. T.W.A. de Bruin 


\section{9: Appendix 'Letter of invitation for participation in the CODAM study for IGT and DM subjects'}

Aan geadresseerde,

Geachte heer/mevrouw,

Enige tijd geleden heeft $u$ de uitslag ontvangen van het Diabetes Onderzoek Maastricht van het Academisch Ziekenhuis Maastricht in samenwerking met het RIVM en de GGD. Uit de uitslagen van de vingerprik nuchter en de vingerprik na de suikerdrank bleek dat $\mathrm{u}$ een verhoogde bloedsuikerspiegel heeft. Verder heeft $\mathrm{u}$ aangegeven geen bezwaar te hebben voor deelname aan een vervolgonderzoek.

Eén van de vervolgonderzoeken die door het Academisch Ziekenhuis Maastricht in samenwerking met de Universiteit Maastricht wordt uitgevoerd is een zogenaamde 'volg'- of cohortstudie. Bij dit onderzoek worden een aantal metingen herhaald om zo te bepalen welke risicofactoren van diabetes (suikerziekte) en atherosclerose (aderverkalking) in de loop van de tijd veranderen. Hieruit kan afgeleid worden welke factoren voorspellend zouden kunnen zijn voor het ontstaan van diabetes en atherosclerose en welke factoren juist beschermen. Voor deze cohortstudie willen wij nu graag uw medewerking vragen.

Bij deze brief is een informatiebrochure gevoegd. Wij willen u vragen deze aandachtig door te lezen. Indien $\mathrm{u}$ aan het onderzoek wilt deelnemen willen wj u vragen ons zo spoedig mogelijk te bellen op tel. nr: (043) 3881638 om een afspraak te maken. Ook wanneer $u$ nog vragen heeft bent $u$ vrij ons te bellen op dit telefoonnummer.

Bij voorbaat dank,

Drs. M. Kruijshoop

mede namens de overige leden van het Onderzoeksteam Diabetes:

Drs. M.R. Mensink

Mw. T.J.F. M.B. Hermans

Mw. I. Nijs

Dr. E.E. Blaak

Prof. Dr. T.W.A. de Bruin 


\subsection{0: Appendix 'Information package'}

Informatiebrochure voor deelnemers aan

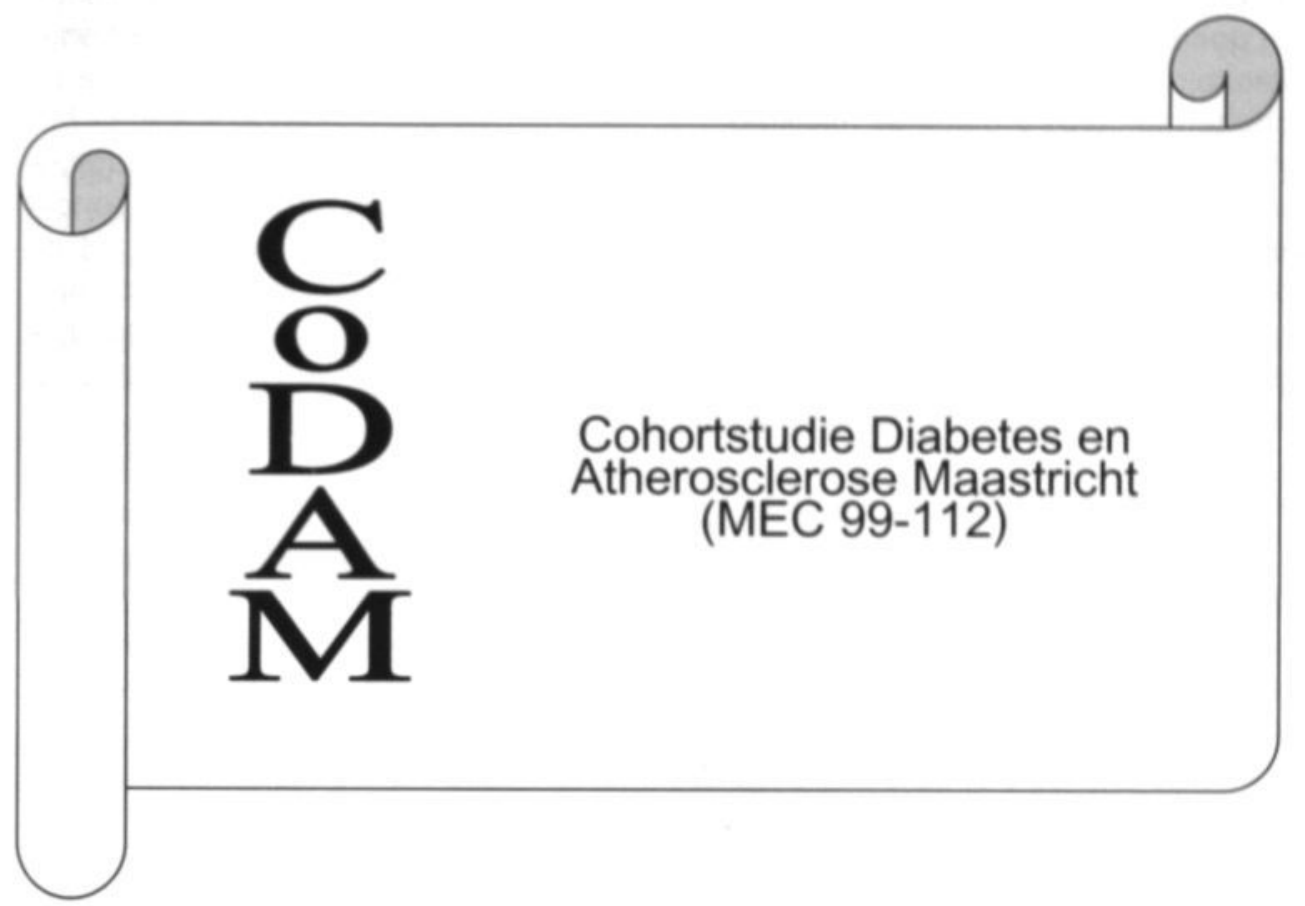

Contactpersonen: - Drs. M. Kruijshoop

: 0433881638

- Drs. M.R. Mensink

2 0433881638

- Dr. E.E. Blaak

2. 0433881639

- Prof. Dr. T.W.A. de Bruin

2 0433877019 


\section{Een onderzoek naar de bijdrage van omgevingsfactoren en erfelijke factoren bij het ontstaan van ouderdoms-suikerziekte en hart- en vaatziekten}

\section{Doel van het onderzoek}

Er zijn sterke aanwijzingen dat, naast roken, weinig lichamelijke inspanning, voedingsen leefgewoonten, ook erfelijke gevoeligheid een rol speelt bij het ontstaan van hart- en vaatziekten. De wijze waarop hart- en vaatziekten bij suikerziekte ontstaan is echter nog niet goed bekend. Wel is bekend dat er in het algemeen een 2 tot 4 keer verhoogd risico kan zijn op het ontstaan van hart- en vaatziekten bij ouderdoms-suikerziekte (in medische termen type 2 diabetes mellitus).

Het doel van dit onderzoek is na te gaan wat de invloed van een aantal erfelijke factoren is op het ontstaan van hart- en vaatziekten bij mensen met en mensen zonder een verhoogd risico op de ontwikkeling van suikerziekte in Maastricht. Ook zal de invloed van een aantal bekende risicofactoren, zoals roken, lichamelijke activiteit, voeding en cholesterolgehalte bekeken worden. Het is voor het onderzoek niet belangrijk of u momenteel onder behandeling van uw huisarts en/of diëtiste staat in verband met een verhoogde bloedsuikerspiegel.

\section{Opzet van het onderzoek}

Het onderzoek zal 5 jaar gaan duren waarin u gevraagd wordt naar het Academisch Ziekenhuis Maastricht of de Universiteit Maastricht te komen. In deze 5 jaar zullen de metingen in totaal drie keer uitgevoerd worden. De metingen bestaan uit'baseline' - of nulmetingen die na drie en vijf jaar herhaald worden waarbij de verschillende onderdelen verdeeld worden over drie bezoeken. $U$ wordt dus gevraagd om in totaal 9 keer naar het ziekenhuis of de universiteit te komen, verspreid over 5 jaar.

De metingen die verricht worden dienen om de bloedsuikerspiegel te bepalen, een aantal risicofactoren in het bloed en in de urine te meten, verschillende erfelijke factoren met betrekking tot ouderdoms-suikerziekte en hart- en vaatziekten te bepalen, de lichaamssamenstelling te meten (de verdeling tussen de hoeveelheid vet en spieren in het lichaam) en de vaatwanddikte te bepalen. Daarnaast wordt u gevraagd een aantal vragenlijsten in te vullen om een goede indruk te krijgen van uw voedingsgewoonten, lichamelijke activiteiten en een aantal zaken betreffende de gezondheid en gezondheidszorg.

Naast de meting van de bloedsuikerspiegel worden er nog een aantal andere factoren in het bloed bepaald zoals het cholesterolgehalte en factoren die een rol spelen bij de bloedstolling. Ook de erfelijke factoren die mogelijk een rol spelen bij het ontstaan van ouderdoms-suikerziekte en hart- en vaatziekten worden uit het afgenomen bloed bepaald.

De erfelijke factoren die worden bepaald spelen een rol bij:

-een verhoogd cholesterol, vetgehalte en aderverkalking.

-overgewicht. Overgewicht is een belangrijke risicofactor voor het ontwikkelen van diabetes.

-hypertensie. Verhoogde bloeddruk gaat vaak samen met suikerziekte.

-stoornissen in de suiker- en vetstofwisseling. Deze komen beide voor bij suikerziekte. 
-de afgifte van het hormoon insuline. Bij ouderdoms-suikerziekte heeft het lichaam meer insuline nodig dan het lichaam zelf (door middel van de alvleesklier) kan aanmaken.

\section{Wat houdt het onderzoek voor $u$ in?}

Hieronder wordt uitgelegd wat er precies gaat gebeuren bij de metingen die gedaan zullen worden tijdens beide bezoeken.

\section{Het eerste bezoek:}

$\mathrm{U}$ wordt gevraagd 's morgens nuchter naar het ziekenhuis of de universiteit te komen (de dag voor het onderzoek na 22:00 uur niets meer eten, niets anders dan water drinken en niet roken). Voor bloeddonoren bij de bloedbank is het belangrijk te weten dat er tussen de laatste bloeddonatie en het eerste bezoek van dit onderzoek minimaal 4 weken tijd moet zitten. Verder willen wij u vragen om met de auto of het openbaar vervoer te komen aangezien fietsen de bloedsuikerspiegel kan beïnvloeden. Gemaakte reiskosten kunnen worden vergoed.

\section{Bloedsuikerspiegel.}

$\mathrm{Na}$ uitleg van het onderzoek wordt eerst het gewicht en de bloeddruk gemeten. Hierna zal een infuus ingebracht worden in een ader van de onderarm. $\mathrm{Na}$ ongeveer $15 \mathrm{~min}$ zal wat bloed worden afgenomen. Uit deze eerste bloedafname zullen, naast de bloedsuikerspiegel, ook een aantal andere factoren bepaald worden, zoals cholesterolgehalte en stollingsfactoren. Hierna wordt de bloedsuikerspiegel direct bepaald met de vingerprik. Vervolgens krijgt u een suikerdrankje te drinken en na 30 minuten wordt voor de tweede maal via het reeds ingebrachte infuus wat bloed afgenomen. Eén uur en twee uur na het drinken van het suikerdrankje zal er nogmaals via het infuus wat bloed worden afgenomen. Tevens wordt na twee uur de bloedsuikerspiegel nogmaals direct gemeten middels de vingerprik. In totaal wordt er dus vier keer via het infuus bloed bij $u$ afgenomen en twee keer een vingerprik uitgevoerd om (onder andere) het verloop van de bloedsuikerspiegel na het suikerdrankje te kunnen bepalen. De eerste keer wordt ongeveer $85 \mathrm{ml}$ bloed afgenomen. De tweede, derde en vierde keer wordt $10 \mathrm{ml}$ bloed afgenomen. $\mathrm{U}$ wordt in totaal echter maar 1 keer in de arm geprikt (aan het begin van het onderzoek) en 2 keer in de vinger (aan het begin en aan het eind van het onderzoek). In totaal zullen er 21 buisjes bloed afgenomen worden, hetgeen overeenkomt met $125 \mathrm{ml}$ bloed $(=0,125$ liter; $u$ heeft zelf ongeveer 5,0 liter bloed).

\section{Urine.}

De urine wordt onderzocht op mogelijke eiwit-uitscheiding. Hiervoor dient u de eerste ochtendurine op de eerste ochtend van het onderzoek op te vangen in bv. een oud jampotje dat $u$ eerst goed heeft afgewassen, nagespoeld en afgedroogd. $U$ kunt hier ook een urinepotje bij uw apotheek voor kopen. Na afloop van uw bezoek krijgt u van ons een tweede potje mee om de ochtendurine op te vangen op de ochtend van uw tweede bezoek. 


\section{Vragenlijsten.}

Om de invloed van levensgewoonten na te gaan wordt u gevraagd een algemene vragenlijst en een gezondheidszorg-vragenlijst in te vullen wat ongeveer een half uur duurt. Deze vragenlijsten zullen door ons opgestuurd worden. U wordt gevraagd deze volledig ingevuld mee te nemen naar het eerste bezoek. De vragenlijst bevat vragen met betrekking tot de volgende onderwerpen: lichamelijke inspanning, rookgewoonten, symptomen van suikerziekte, mogelijk geneesmiddelen gebruik en uw lichamelijke gezondheid. Tijdens de pauzes tijdens de bloedafnames krijgt $u$ een voedingsvragenlijst en een erfelijkheidsformulier. De voedingsvragenlijst kan direct ter plaatse worden ingevuld en het erfelijkheidsformulier worden mee naar huis gegeven.

\section{Het tweede bezoek:}

$\mathrm{U}$ wordt gevraagd naar het ziekenhuis of de universiteit te komen. Deze keer hoeft u niet nuchter te zijn en kunnen de metingen ook 's middags plaatsvinden, maar u wordt wel gevraagd geen alcohol, koffie en thee te gebruiken en niet te roken vanaf 22:00 uur de dag voor het onderzoek. Ook wordt u gevraagd in de twee uur voorafgaande aan de metingen niet te eten en de avond voor de metingen geen zware inspanningen te verrichten.

\section{Halsslagader-onderzoek.}

Er zullen metingen van de dikte van de wand van een bloedvat in de hals gedaan worden met behulp van een echo-apparaat dat zonder druk op de huid van de hals geplaatst wordt. Voor deze laatste meting wordt u gevraagd gedurende 45 minuten rustig op een bed liggen. Dit onderzoek geeft geen extra risico voor de gezondheid.

Tevens zal de bloeddruk gemeten worden en er zal een hartfilmpje (ECG of electrocardiogram) gemaakt worden.

\section{Lichaamssamenstelling.}

De lichaamssamenstelling wordt volgens vijf methoden gemeten. Bij de eerste methode wordt uw lengte en uw gewicht bepaald. De tweede methode bestaat uit het meten van de omtrek van uw taille en heupen met behulp van een meetlint. Bij de derde methode wordt gebruik gemaakt van een schuifmaat om de doorsnede van de buik van links naar rechts en van voor naar achter te meten. De vierde methode bestaat uit het meten van de huidplooidikte van de arm, schouderblad en bekken. Dit wordt gedaan met behulp van een soort tang en is geheel pijnloos. Uit deze metingen kan het vetpercentage berekent worden. Bij de vijfde en laatste methode zal met een bioimpedantiemeter de weerstand van uw lichaam worden gemeten op een eveneens pijnloze wijze. Wij berekenen hieruit de lichaamssamenstelling.

Urine.

$\mathrm{U}$ wordt opnieuw gevraagd de eerste ochtendurine op te vangen in het potje dat u bij uw vorige bezoek hebt meegekregen en dit mee te brengen naar uw tweede bezoek.

\section{Vragenlijst.}

$U$ wordt gevraagd het erfelijkheidsformulier ingevuld mee te brengen naar het tweede bezoek. Het invullen hiervan zal ongeveer een half uur tot een uur duren. 


\section{Risico's.}

De bovengenoemde metingen en procedures vormen geen extra risico voor uw gezondheid. Mocht $u$ toch nadelige medische gevolgen ondervinden ten gevolge van één van de onderzoeken of procedures dan is de Universiteit Maastricht, als instituut, hiervoor verzekerd, evenals het Academisch Ziekenhuis Maastricht. $U$ vindt, ten bewijze hiervan, een afschrift toegevoegd. Deze verzekering bestond overigens altijd al. Nadat u schriftelijk en mondeling van informatie bent voorzien over dit onderzoek door de onderzoekers, kan het voorkomen dat er bij u behoefte bestaat aan nadere inlichtingen over dit onderzoek of over de procedures. Het is mogelijk om deze zaken ook met een onafhankelijk (i.e. niet bij het onderzoek betrokken) arts te bespreken, namelijk de heer P. de Leeuw, internist, of de heer A. Kroon, internist, werkzaam in het Academisch Ziekenhuis Maastricht, afdeling Interne Geneeskunde, telefoon: 043-38 77005.

\section{Privacy}

Al uw gegevens worden vertrouwelijk behandeld. Om de privacy te waarborgen wordt er op onderzoeksdocumenten geen naam, maar een deelnemersnummer vermeld. Resultaten van de lichamelijke onderzoeken zullen altijd aan u medegedeeld worden. Wanneer u de uitkomsten niet wenst te vernemen kan daartegen bezwaar gemaakt worden. De uitslagen van het DNA-onderzoek zullen niet medegedeeld worden in verband met de anonieme verwerking ervan.

\section{Toestemming tot deelname}

Deelname aan deze studie is geheel vrijwillig. $U$ kunt op ieder moment uw medewerking, ook zonder opgaaf van redenen, opzeggen. Voor de start van de studie zullen wij u vragen een verklaring te tekenen waarin $u$ aangeeft voldoende geïnformeerd te zijn over het onderzoek en toestemming geeft tot deelname. $\mathrm{Na}$ toestemming tot deelname zullen uw adresgegevens door het RIVM worden overgedragen aan de Universiteit Maastricht.

$U$ kunt uiteraard ook gedurende het onderzoek te allen tijde om nadere inlichtingen vragen. Mocht u ooit, in het kader van een verzekering of keuring, gevraagd worden of $\mathrm{u}$ bent onderzocht op erfelijke afwijkingen, dan geldt uw medewerking aan dit onderzoek niet als een erfelijkheidsonderzoek, en kunt u de vraag met 'nee' beantwoorden.

\section{Voor vragen kunt u terecht bij:}

Drs M. Kruijshoop, onderzoeker, tel: 0433881638

Drs. M.R. Mensink, arts-onderzoeker, tel: 0433881638

Dr. E.E. Blaak, senior-onderzoeker en voedingsdeskundige, tel: 043388139

Prof. Dr. T.W.A. de Bruin, projectleider en internist-endocrinoloog, tel: 0433877019 


\section{CHAPTER 3}

\section{Study on lifestyle-intervention and impaired glucose tolerance Maastricht (SLIM): design and screening results}

Marco Mensink ${ }^{a}$, Eva Corpeleijn ${ }^{a}$, Edith JM Feskens ${ }^{b}$, Margriet Kruijshoop ${ }^{c}$, Wim HM Saris ${ }^{a}$, Tjerk WA de Bruin ${ }^{c}$, Ellen E Blaak ${ }^{a}$

${ }^{a}$ Department of Human Biology, Nutrition and Toxicology Research Institute Maastricht (NUTRIM), Maastricht University, Maastricht, the Netherlands; ${ }^{b}$ Department of Health and Nutrition, National Institute of Public Health and the Environment, Bilthoven, the Netherlands; ' ${ }^{c}$ Department of Medicine and Endocrinology, Cardiovascular Research Institute Maastricht (CARIM), University Hospital Maastricht, Maastricht, the Netherlands

Diabetes Research and Clinical Practice 2003; 61: 49-58 


\section{Abstract}

The study on lifestyle-intervention and impaired glucose tolerance Maastricht (SLIM) is a 3 years randomised clinical trial designed to evaluate the effect of a combined diet and physical activity intervention program on glucose tolerance in a Dutch population at increased risk for developing type 2 diabetes. Here the design of the lifestyle-intervention study is described and results are presented from the preliminary population screening, conducted between March 1999 and June 2000. In total, 2820 subjects with an increased risk of having disturbances in glucose homeostasis (i.e. age $>40$ years and $\mathrm{BMl}>25 \mathrm{~kg} / \mathrm{m}^{2}$ or a family history of diabetes) underwent a first oral glucose tolerance test (OGTT). Abnormal glucose homeostasis was detected in 826 subjects (30.4\%): 226 type 2 diabetes (type 2DM, 8.3\%), 215 impaired fasting glucose (IFG, 7.9\%) and 385 impaired glucose tolerance (IGT, 14.2\%). Both increasing age and BMI were strongly related to the prevalence of IGT and diabetes. After a second OGTT, 114 subjects with glucose intolerance and in otherwise good health were eligible for participation in the intervention study (SLIM). The high prevalence of disturbances in glucose homeostasis observed in the preliminary screening underscore the importance of early (lifestyle) interventions in those at risk for developing diabetes. SLIM will address this topic in the Dutch population. 


\section{Introduction}

Type 2 diabetes mellitus is rapidly becoming one of the main health issues in the $21^{\text {st }}$ century. Prevalence has increased explosively in the last two decades, and global estimates indicate a further rise from a current 150 million people with diabetes, to 300 million in $2025(1,2)$. Impaired glucose tolerance (IGT) is the obligatory transition state preceding type 2 diabetes. Prevalence of IGT varies widely between populations, from as low as $2.0 \%$ in rural populations to more than $20 \%$ in high-risk populations (3). The cumulative incidence of type 2 diabetes in subjects with IGT ranged from 3.6 to $8.7 \%$ per year in six prospective studies (4), and is strongly related to the fasting and the $2 \mathrm{~h}$ plasma glucose concentrations at the time of IGT recognition $(4,5)$. The most important modifiable risk factor for progression from IGT to diabetes is obesity. Body mass index (BMI) at the time of IGT recognition is a strong predictor of progression, independently of fasting and 2-h blood glucose concentrations (4). Dietary factors, especially a high fat intake, are also related to the risk of conversion from IGT to diabetes (6).

Several recent studies have reported the feasibility and efficacy of interventions to prevent or delay the progression to type 2 diabetes in subjects with IGT (7-13). Acarbose, (13), as well as metformin (12), have been shown to reduce the incidence of diabetes in a population with IGT. Other studies have focused on the potential of lifestyle changes $\mathrm{b}$ reduce the progression rate from IGT to type 2 diabetes. The Finnish diabetes prevention study (DPS) (11) and the US diabetes prevention program (DPP) (12) reported that weight-loss, changes in dietary intake, and increased physical activity resulted in a $58 \%$ reduction in the incidence of diabetes after a mean follow-up of only 3 years. Moreover, lifestyle-intervention was much more effective in reducing the incidence of diabetes than pharmacological intervention (i.e. metformin) (12). It is important to confirm these observations in different populations, with a different dietary and physical activity background, and a different attitude towards changing lifestylehabits.

The study on lifestyle-intervention and impaired glucose tolerance Maastricht (SLIM) is a 3 years randomised clinical trial designed to evaluate the effect of a combined diet and physical activity intervention program on glucose tolerance in a Dutch population at increased risk for developing type 2 diabetes. Furthermore, we will consider changes in anthropometric measurements, aerobic capacity and cardiovascular risk factors. Additional measurements will be performed in subgroups of the study population in a search for underlying mechanisms.

The objective of this report is to describe the design of the lifestyle-intervention study and to evaluate the results of the preliminary population screening, from which the subjects were recruited for the intervention study. Data are presented about the prevalence of disturbances in glucose homeostasis in a middle-aged Dutch population. 


\section{Study design and methods}

SLIM is designed to study whether a diet/physical activity intervention program can improve glucose tolerance in subjects with a high risk for developing type 2 diabetes mellitus. The total duration of the study is 3 years. The medical ethical review committee of Maastricht University approved the study protocol, and all subjects gave their written informed consent before the start of the study.

\subsection{Recruitment of subjects}

The recruitment period started in March 1999 and was completed at the end of May 2000.

\subsubsection{Preliminary screening}

Subjects with an increased risk for glucose intolerance, i.e. those of age $>40$ years and a family history of diabetes or a $\mathrm{BMI}>25 \mathrm{~kg} / \mathrm{m}^{2}$, were selected from a large existing cohort, monitoring health and disease in the general population (14), and invited to undergo a standard oral glucose tolerance test (OGTT) (glucose load $75 \mathrm{~g}$ ) (15). Blood glucose was measured in capillary blood using the Glucometer Elite Bayer, Zurich, Schweiz). Furthermore, body weight was measured, without wearing shoes and jackets. Subjects with known diabetes, or those with fasting glucose values $>8.5$ $\mathrm{mmol} / \mathrm{L}$ did not participate in the OGTT.

\subsubsection{Second OGTT}

Those subjects with a $2 \mathrm{~h}$ blood glucose concentration $>7.8 \mathrm{mmol} / \mathrm{L}$ at the preliminary screening and which were otherwise in good health (i.e. no history of cardiovascular disease, or any (chronic) disease or medication use that makes participation in a lifestyle intervention program impossible) were invited for a second OGTT. During this second OGTT, glucose tolerance was measured in venous plasma. Furthermore a medical history was taken, a physical examination was performed and several additional measurements were performed (see Section 2.3, below).

\subsubsection{Final recruitment}

For definitive inclusion in the lifestyle-intervention study, mean $2 \mathrm{~h}$ glucose concentration of both OGTTs had to be between 7.8 and $12.5 \mathrm{mmol} / \mathrm{L}$, together with a fasting glucose concentration of less than $7.8 \mathrm{mmolL}$. Other inclusion and exclusion criteria for participation in the intervention study are indicated in Table 1. To follow changes in glucose tolerance over time, data obtained by the second (venous) OGTT were used as baseline values. 
Table 1: Inclusion and exclusion criteria for the lifestyle-intervention study (SLIM).

Inclusion criteria
Mean 2-h blood glucose $\geq 7.8$ and $\leq 12.5 \mathrm{mmol} /$

Mean fasting blood glucose $\leq 7.8 \mathrm{mmol}$.

Caucasian

Age $40-70$ years

Exclusion criteria

Known diabetes mellitus
Mean 2-h blood glucose $>12.5 \mathrm{mmol}$.

Mean fasting blood glucose $>7.8$ mmolLI

Any chronic illness that makes 5-years survival improbable, or that interferes with glucose tolerance, or that makes participation in a lifestyle-intervention impossible Medication known to interfere with glucose tolerance

Participation in a vigorous exercise and/or diet program

After final recruitment, subjects were randomised to two study groups, the lifestyle intervention group or the control group. Randomisation was carried out with stratification for sex and mean $2 \mathrm{~h}$ plasma glucose concentration.

Based on the preliminary results after 1 year of the Finnish DPS (16), we calculated that 50-60 subjects per group would be sufficient to detect a $1.0 \mathrm{mmol} / \mathrm{L}$ difference in the $2 \mathrm{~h}$ glucose concentration between groups.

\subsection{Lifestyle-intervention program}

The intervention program consists of a dietary and physical activity part.

\subsubsection{Dietary intervention}

Dietary recommendations are based on the Dutch guidelines for a healthy diet (Dutch Nutrition Council, 1992, see Table 2). Participants are encouraged to stop smoking and, if necessary, to reduce alcohol intake. Dietary advice is given at regular intervals by a skilled dietician on an individual basis after consideration of a 3 days food record (see Table 2). A body weight loss of $5-7 \%$ is the objective. If subjects do not loose weight on this regimen during the first year, mild energy restriction is prescribed during the second year. No very-low calorie diet or dietary products are used to encourage weight loss.

\subsubsection{Exercise intervention}

Subjects are encouraged to increase their level of physical activity to at least $30 \mathrm{~min}$ of moderate physical activity a day for at least 5 days a week (17). Individual advice is given on how to increase daily physical activity (walking, cycling, swimming), and goals are set. Furthermore, subjects are encouraged to participate in an exercise program, especially designed for this study, including components of aerobic exercise training and components of resistance training (18). Subjects have free access to these training sessions, and are stimulated to participate for at least $1 \mathrm{~h}$ a week. Participation in the exercise sessions is recorded.

\subsubsection{Control group}

Subjects in the control group are given oral and written information, about the beneficial effects of a healthy diet, weight loss and increased physical activity, whereas no individual advice or programs are provided. No additional appointments are scheduled, apart from the annual visits for follow-up measurements. 
Table 2: Details of the dietary intervention.

Dietary guidelines

$\begin{array}{ll}\text { Carbohydrates: } & \pm 55 \% \text { energy } \\ & \begin{array}{l}\text { Maximum } 15-25 \% \text { energy mono- and } \\ \text { disaccharides } \\ \\ \end{array} \\ \text { Fat: } & \leq 10 \% \text { energy saturated fatty acids } \\ & <33 \mathrm{mg} / \mathrm{MJ} \text { cholesterol, maximal } 300 \mathrm{mg} \text { a day } \\ & 10-15 \% \text { energy } \\ \text { Proteins: } & \pm 0.8 \mathrm{~g} / \mathrm{kg} \text { bodyweight } \\ & >3 \mathrm{gJ} \text { a day }\end{array}$

\begin{tabular}{lll} 
Visit & Time & Visit and Topic \\
\hline 1 & 0 & Baseline visit \\
2 & $4-6$ weeks & Discussion baseline food-record \\
3 & 3 months & 'Fat' \\
4 & 6 months & 'Carbohydrates' \\
5 & 9 months & Group-session: 'label-reading' and 'novel foods' \\
6 & 12 months & 1 -year meeting \\
& & \\
7 & 15 months & 'Artificial sweeteners' \\
8 & 18 months & 'Special occasions, e.g. a party' \\
9 & 21 months & Group-session: 'a dietary game' \\
10 & 24 months & 2-year meeting \\
& & \\
11 & 27 months & 'Vegetarian food' \\
12 & 30 months & Vitamins and minerals' \\
13 & 33 months & Group-session: 'lifestyle and diabetes' \\
14 & 36 months & 3-year meeting \\
\hline
\end{tabular}

\subsection{Measurements}

At the start of the study, and every year thereafter several measurements are performed, in both the intervention and control group.

\subsubsection{Laboratory assessments}

A standard OGTT is performed every year, according to the guidelines described by the WHO (15). Venous blood samples are immediately centrifuged and plasma is frozen at $-80{ }^{\circ} \mathrm{C}$ until analysis. Plasma glucose and FFA concentrations are measured using standard enzymatic techniques (Glucose HK 125, ABX diagnostics, Montpellier, France; FFA-C test kit, Wako Chemicals, Neuss, Germany, respectively). Plasma insulin concentration is measured with an ELISA assay (Mercodia, Uppsala, Sweden) which shows no cross-reactivity with pro-insulin. Glycated haemoglobin ( $\mathrm{HbA1c}$ ) is determined with the HPLC technique (reference value for our laboratory 4.4-6.2\%). Insulin sensitivity is estimated with the HOMA-index and insulin secretion with the insulinogenic index 30' (Insulin30-Insulin0)/(glucose 30-glucose0) (19). Blood lipids are measured with standard enzymatic techniques in fasting serum samples (triglycerides: 
Sigma, St. Louis, USA; cholesterol: cholesterol 100, ABX diagnostics; HDL: HDL-C Roche, Indianapolis, USA). LDL cholesterol is calculated according to the formula of Friedewald (20).

\subsubsection{Anthropometry}

Body weight is measured on an electronical scale. BMI is calculated as the ratio of weight and height squared $\left(\mathrm{kg} / \mathrm{m}^{2}\right)$. Skinfold measurements are performed to calculate fat mass, fat free mass and body fat percentage (21). Waist circumference (waist) is measured at the level midway between the lowest rib and the iliacal crest. Hip circumference is measured as the maximum circumference over the buttocks. Sagittal and transverse abdominal diameter are measured with the subject in a recumbent position, at the level of the iliacal crest using a sliding beam calliper.

\subsubsection{Maximal aerobic capacity}

To evaluate changes in aerobic fitness, an incremental exhaustive exercise test is performed on an electronically braked bicycle ergometer (Lode Excalibur, Groningen, Netherlands). The test starts at a workload of 0.75 W/kg FFM for $3 \mathrm{~min}$, followed by 3 $\mathrm{min}$ at $1.5 \mathrm{~W} / \mathrm{kg}$ FFM. Subsequently, workload is increased every $3 \mathrm{~min}$ by $0.5 \mathrm{~W} / \mathrm{kg}$ FFM until exhaustion. $\mathrm{O} 2$ consumption and $\mathrm{CO} 2$ production are measured with an Oxycon-Beta (Mijnhardt, Breda, Netherlands) to define maximal peak VO2.

\subsubsection{Other measurements}

At every (annual) visit a physical examination is performed, including recording a 12 lead resting ECG. Blood pressure is measured twice on the right arm with a standard sphygmomanometer, after at least 10 min of rest. Subjects taking any blood pressurelowering medication are asked not to take these on the morning of the measurements. A 3 days food record ( 2 weekdays and 1 weekend day) is kept at the start of the study and every year thereafter. Food records are checked by a dietician and intake of nutrients is calculated with a computer program according to the Dutch food table.

\subsubsection{Outcome}

Primary outcome measure is the change in glucose tolerance (i.e. $2 \mathrm{~h}$ plasma glucose), one of the most important risk factors for progression to diabetes (4). Secondary outcome measures are changes in fasting plasma glucose concentration, plasma insulin concentration, insulin resistance, HbA1c, and changes in body weight, body composition and VO2max. Furthermore changes in cardiovascular risk factors are assessed (blood pressure and blood lipid profile).

\subsection{Statistical analysis}

Data from the intervention study are analysed according to the intention-to-treat principle. Differences between groups (over time) are analysed by unpaired t-tests or ANOVA (repeated measures). The level of significance is set at 0.05 .

Results of the preliminary screening were analysed with ANOVA (differences between categories) and Chi-square-testing (frequency distribution of disturbances in glucose homeostasis). 


\section{Results}

In total 6108 subjects were invited to participate in the preliminary screening. Of those, 2820 subjects were willing to participate in this first OGTT. Non-response was observed in 3288 cases $(53.8 \%)$. Mean age of the non-responders was $55.7 \pm 0.1$ years, which was significantly lower than the responders $(\mathrm{N}=2820$; age $56.8 \pm 0.1$; p-value $<0.001)$. No difference was seen in gender between responders and non-responders (50.6 male vs. $50.9 \%$ male, respectively, $p=N S$ ). After considering the selection criteria, 379 men and women were invited for the second OGTT, of whom 177 were willing to participate. Finally, 114 subjects, 64 men and 50 women, were included in the lifestyle intervention study (SLIM).

From the 2820 subjects participating in the screening OGTT, 105 were excluded from the analysis: 48 because of recently diagnosed diabetes; 57 because of nonCaucasian ethnicity, non-fasting state, or incomplete data. Results from the remaining 2715 subjects are depicted in Table 3 . WHO criteria of 1999 for capillary plasma were applied, as the Glucometer Elite measures glucose levels equivalent to capillary plasma (15). Abnormal glucose homeostasis was detected in 826 subjects (30.4\%): 226 subjects with type 2 diabetes (type 2DM, 8.3\%), 215 with impaired fasting glucose (IFG, $7.9 \%$ ) and 385 with impaired glucose tolerance (IGT, 14.2\%). Of the latter group, almost two-thirds ( $N=244)$ had normal fasting glucose (NFG/IGT) and one-third ( $N=141)$ impaired fasting glucose (IFG/IGT). The prevalence of type $2 \mathrm{DM}$ and IFG was higher among men than women. A strong upward trend for age and BMI was seen from NGT to type 2 DM, with IGT and IFG in between (Table 3).

In Table 4 the prevalence of NGT, IFG, IGT and type 2 DM is given for age and BMI groups, for men and women separately. In both men and women, prevalence of disturbed glucose homeostasis increased with age, except for IFG which reached the highest prevalence in the age group of 55-59 years. In the population of 65 years and

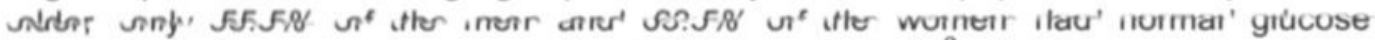
homeostasis. In men and women with a BMI above $30 \mathrm{~kg} / \mathrm{m}^{2}$, diabetes was three times more prevalent and IFG and IGT were two times more prevalent, compared with those with a BMI below $27 \mathrm{~kg} / \mathrm{m}^{2}$. The prevalence of newly diagnosed diabetes was almost two times higher in men than in women in each BMI and age group. Likewise, IFG was 1.5 times more frequent in men than in women, especially in the age groups below 55 years. Additionally, more women were normoglycaemic than men $(p<0.001)$.

Table 3: Results of the preliminary screening ( $N=2715)$.

\begin{tabular}{lllllll}
\hline & & NGT & IFG & IGT & type 2 DM & P-value $^{\dagger}$ \\
\hline number & $(\%(\mathrm{~N}))$ & $69.9(1889)$ & $7.9(215)$ & $14.2(385)$ & $8.3(226)$ & \\
sex & $(\%$ male $)$ & 47.5 & 61.2 & 49.1 & 67.8 & $<0.0001$ \\
age & $($ year) & $55.9 \pm 0.2$ & $58.8 \pm 0.4$ & $57.1 \pm 0.5$ & $59.8 \pm 0.4$ & $<0.0001$ \\
BMI & $\left(\mathrm{kg} / \mathrm{m}^{2}\right)$ & $28.0 \pm 0.1$ & $29.7 \pm 0.3$ & $29.5 \pm 0.2$ & $30.6 \pm 0.3$ & $<0.0001$ \\
FBG & $(\mathrm{mmol} / \mathrm{L})$ & $5.2 \pm 0.1$ & $6.3 \pm 0.1$ & $5.8 \pm 0.1$ & $7.4 \pm 0.1$ & $<0.0001$ \\
2h BG & $(\mathrm{mmo} / \mathrm{L})$ & $6.5 \pm 0.1$ & $6.8 \pm 0.1$ & $10.1 \pm 0.1$ & $13.0 \pm 0.2^{*}$ & $<0.0001$ \\
\hline
\end{tabular}

Data are mean \pm sem; FBG $=$ Fasting Blood Glucose, $2 \mathrm{~h} \mathrm{BG}=2$-hour Blood Glucose; ${ }^{\dagger}$ ANOVA, comparison of frequencies was done by a Chi-square test; ${ }^{*}$ subjects with fasting glucose $>8.5 \mathrm{mmol}$ did not undergo an OGTT ( $\mathrm{N}=28)$. 
Table 4: Prevalence of disturbances in glucose homeostatis according to age and BMI groups, for men and women separately $(\mathrm{N}=2715)$.

\begin{tabular}{lcccccccccc}
\hline & MEN & \multicolumn{10}{c}{ WOMEN } \\
\cline { 2 - 11 } & $\mathrm{N}$ & $\begin{array}{l}\text { DM } \\
(\%)\end{array}$ & $\begin{array}{l}\text { IGT } \\
(\%)\end{array}$ & $\begin{array}{c}\text { IFG } \\
(\%)\end{array}$ & $\begin{array}{c}\text { NGT } \\
(\%)\end{array}$ & N & $\begin{array}{c}\text { DM } \\
(\%)\end{array}$ & $\begin{array}{c}\text { IGT } \\
(\%)\end{array}$ & $\begin{array}{c}\text { IFG } \\
(\%)\end{array}$ & $\begin{array}{c}\text { NGT } \\
(\%)\end{array}$ \\
\hline Age & & & & & & & & & & \\
$<50$ & 289 & 6.6 & 8.0 & 6.2 & 79.2 & 254 & 0.8 & 9.1 & 2.4 & 87.8 \\
$50-54$ & 256 & 7.8 & 10.2 & 13.7 & 68.4 & 252 & 2.4 & 13.9 & 6.7 & 77.0 \\
$55-59$ & 289 & 11.1 & 14.5 & 12.5 & 61.9 & 281 & 6.8 & 14.6 & 7.8 & 70.8 \\
$60-64$ & 301 & 14.0 & 16.3 & 9.0 & 60.8 & 322 & 8.6 & 15.8 & 6.8 & 70.5 \\
$=65$ & 238 & 16.8 & 20.6 & 7.1 & 55.5 & 233 & 10.3 & 19.7 & 6.4 & 63.5 \\
BMI & & & & & & & & & & \\
$<27$ & 477 & 6.7 & 10.5 & 6.1 & 76.7 & 515 & 3.1 & 10.1 & 4.1 & 82.7 \\
$27-30$ & 484 & 8.9 & 10.5 & 9.7 & 70.9 & 415 & 4.1 & 15.7 & 5.5 & 74.7 \\
$=30$ & 412 & 18.9 & 21.4 & 13.8 & 45.9 & 412 & 9.7 & 19.2 & 9.2 & 61.9 \\
& & & & & & & & & & \\
\hline Total & 1373 & 11.1 & 13.8 & 9.7 & 65.4 & 1342 & $5.4 *$ & 14.6 & $6.1^{* *}$ & $73.8^{* *}$ \\
\hline
\end{tabular}

" $p<0.001$ between sexes (Chi-square test).

\section{Discussion}

\subsection{Lifestyle-intervention}

The justification of lifestyle-intervention studies is that they may prevent or postpone the onset of type 2 diabetes and related complications. Both the Finnish DPS and the US DPP reported that changing dietary and physical activity habits reduce the incidence of diabetes by about $58 \%(11,12)$. Confirmation of these results in different populations is important. SLIM will consider this in a middle-aged Dutch population at increased risk for diabetes. The Dutch population has a low prevalence of obesity (22), and Dutch subjects are known for their relatively high level of physical activity. In 1997 slightly more than one-half of the population was, on average, moderately active for more than half an hour per day (23), compared with about one-third of US adults (24). As obesity and physical activity are important factors associated with diabetes, it is important to know whether lifestyle changes result in a comparable risk reduction in the Dutch population as in the Finnish and American population.

Dietary and physical activity intervention strategies are combined, as earlier reports indicated that the combination is most effective $(25,26)$. The intervention strategy in this randomised study is based on general public health recommendations for nutritional intake and physical activity. A regimen, based on general recommendations, is much more suitable to prevent diabetes, as it is less time consuming and much better tolerated than very intensive intervention programmes. Furthermore, we will perform additional measurements in small subgroups of the intervention and control population $(\mathrm{N}=10$ per group) using stable isotopes, indirect calorimetry and muscle biopsies. Since type 2 diabetes and IGT are characterised by disturbances in skeletal muscle fatty acid uptake and oxidation (27-29), the question will be addressed whether changes in glucose tolerance are accompanied by changes in skeletal muscle fatty acid 
metabolism. These additional measurements could identify some of the mechanisms underlying the development of insulin resistance and type 2 diabetes mellitus.

\subsection{Methodological considerations}

Participation rate was relatively low in the present study, approximately $50 \%$. As subjects were selected from an ongoing monitoring project for health and disease, some 'research-fatigue' could not be excluded, and this could have led to some selection bias. Classification of the subjects was based on a single OGTT (with the Glucometer Elite), and was not confirmed by repeated testing as recommended. Some misclassification might have occurred because of the known high intra-individual variability in glucose levels. However, a previous Dutch study showed that the prevalence of IGT and diabetes was not different between the first and the second test (30). Only when the diagnosis was based on meeting classification criteria at both OGTT's, did the prevalence decrease. Finally, we tested the consistency in classification between measurements made with the Glucometer Elite and measurements made with a standard enzymatic technique in venous plasma. Consistency in classification according to the WHO criteria was good (69\%, kappa 0.55 , p-value $<0.001 ; \mathrm{N}=245$; (31)).

\subsection{Preliminary screening}

The results of the preliminary screening confirm the high-risk profile of the population under study. Three out of every ten subjects had disturbed glucose homeostasis, which is quite comparable with the results reported in the STOP-NIDDM trial, which also screened in a high-risk population (32). The prevalence of IGT and newly diagnosed diabetes in the screening population was higher than reported in the Dutch Hoorn Study over the period $1989-1992$ (10.3\% for IGT and $4.8 \%$ for newly diagnosed diabetes (33)). This may reflect the world-wide increasing prevalence of disturbances in glucose homeostasis (1), and parallels the increasing prevalence of obesity reported in the Dutch population (22). However, in the Hoorn study the old WHO criteria (1985) were used. Since the fasting glucose level for the diagnosis of diabetes has now been reduced, this could partly explain the higher prevalence of diabetes in our study, but not the higher prevalence of IGT.

In line with other populations, the present study confirmed that IGT is considerably more prevalent than IFG, and that overlap between the two categories is limited (3). This limited overlap points towards the difference in metabolic background: IGT is primarily associated with insulin resistance while IFG is associated with a more pronounced defect in insulin secretion and endogenous glucose output (34).

A strong positive relation was observed between increasing age and prevalence of IGT and diabetes. For IFG, the highest prevalence was seen in middle-aged subjects (aged 55-59 years). This is a consistent finding in European populations, particularly among men (3). The prevalence of disturbances in glucose homeostasis was almost 2fold higher in the group with a BMI>30 kg/m ${ }^{2}$ compared with those with a BMI<30 $\mathrm{kg} / \mathrm{m}^{2}$. This underscores earlier reports, showing dramatic increases in the relative risk of diabetes in the highest BMI groups, compared with the lowest BMI group (35). 
Type 2 diabetes is generally more prevalent in women compared with men (1). In contrast, we observed a prevalence of diabetes being two times higher in males than in females, in all BMI and age groups. In the Finnmark study (36), BMI was reported to be a dominant risk factor for both sexes. In women, however, the relationship was confounded by other factors such as blood pressure, height, HDL, glucose, smoking and physical activity. Furthermore, in addition to over-all adiposity, body fat distribution is an important risk factor for diabetes (35). Thus, differences in other risk factors, beside age and BMI, can underlie the observed higher prevalence of diabetes in men in the present study.

\subsection{Conclusion}

The high prevalence of disturbances in glucose homeostasis observed in the preliminary screening underscores the importance of early interventions in those at risk for developing diabetes. Changes in dietary habits and physical activity have shown to reduce the incidence of diabetes. Additional studies are required to confirm these results in different populations with a dfferent dietary and physical activity background. SLIM will address this question in the Dutch population.

\section{Acknowledgements}

We are grateful to Rob van Dam, Tanja Hermans-Limpens, and Ilse Nijs for their work during the preliminary screening. Thid study is supported by grants from the Netherlands Organisation for Scientific Research (ZonMW: 940-35-034) and the Dutch Diabetes Research Foundation (DFN: 98.901).

\section{References}

1. H. King, R.E. Aubert and W.H. Herman, Global burden of diabetes, 1995-2025: prevalence, numerical estimates, and projections. Diabetes Care 21 (1995), pp. 1414-1431.

2. P. Zimmet, K.G. Alberti and J. Shaw, Global and societal implications of the diabetes epidemic. Nature 414 (2001), pp. 782-787.

3. N. Unwin, J. Shaw, P. Zimmet and K.G. Alberti, Impaired glucose tolerance and impaired fasting glycaemia: the current status on definition and intervention. Diabetic Med. 19 (2002), pp. 708-723.

4. S.L. Edelstein, W.C. Knowler, R.P. Bain et al., Predictors of progression from impaired glucose tolerance to NIDDM: an analysis of six prospective studies. Diabetes 46 (1997), pp. 701-710.

5. F. de Vegt, J.M. Dekker, A. Jager et al., Relation of impaired fasting and postload glucose with incident type 2 diabetes in a Dutch population: the Hoorn Study. J. Am. Med. Assoc. 285 (2001), pp. 2109-2113.

6. J.A. Marshall, S. Hoag, S. Shetterly and R.F. Hamman, Dietary fat predicts conversion from impaired glucose tolerance to NIDDM. The San Luis Valley Diabetes Study. Diabetes Care 17 (1994), pp. 50-56.

7. K.F. Eriksson and F. Lindgarde, Prevention of type 2 (non-insulin-dependent) diabetes mellitus by diet and physical exercise. The 6-year Malmo feasibility study. Diabetologia 34 (1991), pp. $891-$ 898.

8. R.C. Page, K.E. Harnden, J.T. Cook and R.C. Turner, Can lifestyles of subjects with impaired glucose tolerance be changed? A feasibility study. Diabetic Med. 9 (1992), pp. 562-566.

9. D.M. Bourn, J.I. Mann, B.J. McSkimming, M.A. Waldron and J.D. Wishart, Impaired glucose tolerance and NIDDM: does a lifestyle intervention program have an effect. Diabetes Care 17 (1994), pp. 1311-1319. 
10. X.R. Pan, G.W. Li, Y.H. Hu et al., Effects of diet and exercise in preventing NIDDM in people with impaired glucose tolerance. The Da Qing IGT and Diabetes Study. Diabetes Care 20 (1997), pp. 537-544.

11. J. Tuomilehto, J. Lindstrom, J.G. Eriksson et al., Prevention of type 2 diabetes mellitus by changes in lifestyle among subjects with impaired glucose tolerance. New Engl. J. Med. 344 (2001), pp. 1343-1350.

12. W.C. Knowler, E. Barrett-Connor, S.E. Fowler et al., Reduction in the incidence of type 2 diabetes with lifestyle intervention or metformin. New Engl. J. Med. 346 (2002), pp. 393-403.

13. J.L. Chiasson, R.G. Josse, R Gomis, M. Hanefeld, A. Karasik and M. Laakso, Acarbose for prevention of type 2 diabetes mellitus: the STORNIDDM randomised trial. Lancet 359 (2002), pp. 2072-2077.

14. R.M. van Dam, J.M. Boer, E.J. Feskens and J.C. Seidell, Parental history of diabetes modifies the association between abdominal adiposity and hyperglycemia. Diabetes Care 24 (2001), pp. 1454 1459.

15. World Health Organization, Definition, diagnosis and classification of diabetes mellitus, Report of a WHO Consultation. Part 1: Diagnosis and Clas sification of Diabetes Mellitus, Geneva, Switzerland, 1999, Publication WHO/NCD/NCS/99.2.

16. J. Eriksson, J. Lindstrom, T. Valle et al., Prevention of Type II diabetes in subjects with impaired glucose tolerance: the Diabetes Prevention Study (DPS) in Finland. Study design and 1-year interim report on the feasibility of the lifestyle intervention programme. Diabetologia 42 (1999), pp. 793-801.

17. American College of Sports Medicine Position Stand, The recommended quantity and quality of exercise for developing and maintaining cardiorespiratory and muscular fitness, and flexibility in healthy adults, Med. Sci. Sports Exerc. 30 (1998), pp. 975-991.

18. J. Eriksson, J. Tuominen, T. Valle et al., Aerobic endurance exercise or circuit-type resistance training for individuals with impaired glucose tolerance. Horm. Metab. Res. 30 (1998), pp. 37-41.

19. M. Albareda, J. Rodriguez-Espinosa, M. Murugo, A. de Leiva and R. Corcoy, Assessment of insulin sensitivity and beta-cell function from measurements in the fasting state and during an oral glucose tolerance test. Diabetologia 43 (2000), pp. 1507-1511.

20. W.T. Friedewald, R.I. Levy and D.S. Fredrickson, Estimation of the concentration of low -density lipoprotein cholesterol in plasma, without use of the preparative ultracentrifuge. Clin. Chem. 18 (1972), pp. 499-502.

21. J.V. Durnin and J. Womersley, Body fat assessed from total body density and its estimation from skinfold thickness: measurements on 481 men and women aged from 16 to 72 years. Br. J. Nutr. 32 (1974), pp. 77-97.

22. T.L. Visscher, D. Kromhout and J.C. Seidell, Long-term and recent time trends in the prevalence of obesity among Dutch men and women. Int. J. Obes. Relat. Metab. Disord. 26 (2002), pp. 12181224.

23. A.J. Schuit, E.J. Feskens and J.C. Seidell, Physical activity in relation to sociodemographic variables and health status of adult men and women in Amsterdam, Doetinchem and Maastricht. Ned Tijdschr Geneeskd 143 (1999), pp. 1559-1564

24. D.A. Jones, B.E. Ainsworth, J.B. Croft, C.A. Macera, E.E. Lloyd and H.R. Yusuf, Moderate leisuretime physical activity: who is meeting the public health recommendations? A national cross sectional study. Arch. Fam. Med. 7 (1998), pp. 285-289.

25. P.A. Torjesen, K.I. Birkeland, S.A. Anderssen, I. Hjermann, I. Holme and P. Urdal, Lifestyle changes may reverse development of the insulin resistance syndrome. The Oslo Diet and Exercise Study: a randomized trial. Diabetes Care 20 (1997), pp. 26-31.

26. G. Li, Y. Hu, W. Yang et al., Effects of insulin resistance and insulin secretion on the efficacy of interventions to retard development of type 2 diabetes mellitus: the DA Qing IGT and Diabetes Study. Diabetes Res. Clin. Pract. 58 (2002), pp. 193-200. 
27. D.E. Kelley and J.A. Simoneau, Impaired free fatty acid utilization by skeletal muscle in non-insulindependent diabetes mellitus. J. Clin. Invest. 94 (1994), pp. $2349-2356$.

28. E.E. Blaak, A.J. Wagenmakers, J.F. Glatz et al., Plasma FFA utilization and fatty acid-binding protein content are diminished in type 2 diabetic muscle. Am. J. Physiol. Endocrinol. Metab. 279 (2000), pp. E146-E154.

29. M. Mensink, E.E. Blaak, M.A. van Baak, A.J. Wagenmakers and W.H. Saris, Plasma free fatty acid uptake and oxidation are already diminished in subjects at high risk for developing type 2 diabetes. Diabetes 50 (2001), pp. 2548-2554.

30. J.M. Mooy, P.A. Grootenhuis, H. de Vries et al., Intra-individual variation of glucose, specific insulin and proinsulin concentrations measured by two oral glucose tolerance tests in a general Caucasian population: the Hoorn Study. Diabetologia 39 (1996), pp. 298-305.

31. M. Kruijshoop, E.J.M. Feskens, E.E. Blaak, R.J. Heine and T.W.A. de Bruin, Validation of capillary glucose measurements to detect type 2 diabetes mellitus in the general population: the CoDAM. study. Diabetologia 42 (2002), p. A98 abstract.

32. J.L. Chiasson, R. Gomis, M. Hanefeld, R.G. Josse, A. Karasik and M. Laakso, The STORNIDDM Trial: an international study on the efficacy of an alpha-glucosidase inhibitor to prevent type 2 diabetes in a population with impaired glucose tolerance: rationale, design, and preliminary screening data. Study to prevent non-insulin-dependent diabetes mellitus. Diabetes Care 21 (1998), pp. 1720-1725.

33. J.M. Mooy, P.A. Grootenhuis, H. de Vries et al., Prevalence and determinants of glucose intolerance in a Dutch caucasian population. The Hoom Study. Diabetes Care 18 (1995), pp. 12701273.

34. C. Weyer, C. Bogardus and R.E. Pratley, Metabolic characteristics of individuals with impaired fasting glucose and/or impaired glucose tolerance. Diabetes 48 (1999), pp. 2197-2203.

35. J.M. Chan, E.B. Rimm, G.A. Colditz, M.J. Stampfer and W.C. Willett, Obesity, fat distribution, and weight gain as risk factors for clinical diabetes in men. Diabetes Care 17 (1994), pp. 961-969.

36. I. Njolstad, E. Amesen and P.G. Lund-Larsen, Sex differences in risk factors for clinical diabetes mellitus in a general population: a 12-year follow-up of the Finnmark Study. Am. J. Epidemiol. 147 (1998), pp. 49-58 


\section{CHAPTER 4}

\section{Validation of Capillary Glucose Measurements to Detect Glucose Intolerance or Type 2 Diabetes Mellitus in the General Population}

Margriet Kruijshoop ${ }^{a}$, Edith JM Feskens ${ }^{b}$, Ellen E Blaak ${ }^{c}$ and Tjerk WA de Bruin ${ }^{a}$

a Department of Internal Medicine, Laboratory for Molecular Metabolism and Endocrinology, Cardiovascular Research Institute Maastricht (CARIM), Maastricht University, Maastricht, the Netherlands: ${ }^{b}$ Department of Nutrition and Health, Food and Consumer Safety Division, National Institute of Public Health and the Environment,

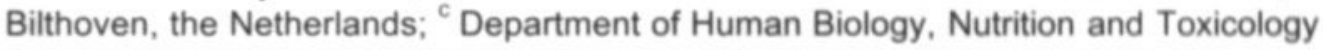
Research Institute Maastricht (NUTRIM), Maastricht University, Maastricht, the Netherlands

Clinica Chimica Acta 2004; 341: $33-40$ 


\section{Abstract}

Background: The use of an oral glucose tolerance test (OGTT) has been recommended to diagnose type 2 diabetes, but an OGTT with venous blood sampling may not be feasible in the screening phase preceding large epidemiological studies. We have conducted a population-based screening in $\mathbf{2 7 1 5}$ men and women and evaluated the diagnostic validity of capillary plasma glucose concentration measurements versus venous plasma glucose concentration measurements in a subset of 350 subjects.

Method: During a single OGTT, glucose concentrations were measured in venous plasma as well as in capillary plasma.

Results: Based on the 1999 WHO criteria for venous glucose concentrations, the study population $(\mathrm{N}=350)$ yielded 97 subjects with type 2 diabetes mellitus, 77 subjects with impaired glucose tolerance and 176 subjects with normal glucose tolerance. Sensitivity and specificity to diagnose type 2 diabetes mellitus by capillary plasma were $84 \%$ and $98 \%$, respectively. Consistent classification by either venous or capillary plasma glucose measurements was $78 \%(k=0.65, p<0.001)$.

Conclusion: Capillary glucose measurements are suitable for use in epidemiological studies to diagnose and detect type 2 diabetes and normal glucose tolerance. Use of capillary measurements can result in costeffective inclusion schemes in epidemiological studies. 


\section{Introduction}

The standard 75-g oral glucose tolerance test (OGTT) has been recommended by the World Health Organization (WHO) in population studies of glucose intolerance and diabetes (1). Capillary blood glucose measurements may constitute an alternative for venous blood glucose measurements in population studies, specifically during the screening phase, because they are easier, less expensive and less invasive to obtain. Capillary blood sampling requires less skills, but resulting glucose measurements may be more dependent on the properties of the materials used and may have a different time course of glucose concentrations. Recent studies have shown that modern handheld glucose measuring devices have excellent technical characteristics and yield similar results as for reference laboratory methods $(2,3)$. However, very few studies have addressed the performance of hand-held glucose measuring devices in the setting of a large-scale epidemiological study.

Several reports have evaluated differences between capillary and venous blood samples in whole blood and plasma (4-13). Most reports indicate that there is no difference in measured glucose concentrations in capillary and venous blood samples in the fasting state $(47,12)$. They also reported that capillary blood glucose concentrations are higher than venous blood glucose concentrations in the non-fasting state, both in subjects with and without diabetes. Recently, new criteria have been published by the American Diabetes Association (ADA) (14) and the WHO (1) to diagnose type 2 dabetes based on glucose levels in venous plasma and whole blood, as well as in capillary plasma and whole blood. This has led to further evaluation of these criteria in recent literature (15-18). It was the objective of the present study to evaluate whether capillary blood glucose measurements are a valid method to screen populations for type 2 diabetes in comparison to the standard venous OGTT using the 1999 WHO criteria. We therefore examined: (a) diagnostic properties of capillary blood glucose measurements; (b) differences between capillary and venous blood glucose measurements, both in the fasting and non-fasting state; and (c) the impact of the degree of glucose tolerance on capillary and venous glucose concentrations after an OGTT.

\section{Materials and Methods}

\subsection{Subjects}

The Cohort study Diabetes and Atherosclerosis Maastricht (CoDAM) is a prospective population-based cohort study in the Netherlands directed at the effects of glucose, i.e. normal glucose tolerance (NGT), impaired glucose tolerance (IGT) and type 2 diabetes mellitus (DM), and at the effects of lipids, lifestyle and genetics on cardiovascular complications. Inclusion criteria were: age 40-70 years and either a BMI > $25 \mathrm{~kg} / \mathrm{m}^{2}$, a positive family history for type 2 diabetes mellitus, a history of gestational diabetes, the use of antihypertensive medication, a postprandial blood glucose larger than 6.0 $\mathrm{mmol} / \mathrm{L}$ or glucosuria. Combinations of these separate inclusion criteria were allowed. Exclusion criteria were the use of medication that affects glucose metabolism and non- 
Caucasian ethnicity. From February 1999 until March 2000, 2715 subjects participated in the screening phase of the CoDAM study which was carried out with capillary plasma glucose measurements. According to the 1999 WHO criteria for capillary glucose (1), 226 of 2715 subjects $(8.3 \%)$ had newly diagnosed DM, $385(14.2 \%)$ were IGT, 215 (7.9\%) had impaired fasting glucose (IFG) and 1889 (69.6\%) were classified as NGT.

All newly diagnosed DM subjects, as well as 291 IGT and 728 NGT (randomly selected) subjects were invited to the inclusion phase of the CoDAM study. Moreover, 49 subjects who were known to have had DM for more than 1 year but no longer than 4 years were invited. Participants underwent a second OGTT with venous plasma glucose measurements (see below) in order to establish their glucose tolerance status. Eventually, 100 newly diagnosed DM, 47 known DM, 103 IGT, 25 IFG and 299 NGT subjects were included in the CoDAM study ( $N=574$, response $46 \%$ ). Of these 574 subjects, 350 were consecutively included in the present study. All subjects gave written informed consent. The study was approved by the local Medical Ethical Committee of the University of Maastricht and University Hospital Maastricht.

\subsection{Measurements}

Glucose tolerance was defined according to the 1999 WHO criteria (1) and was measured by a standard $75-\mathrm{g}$ oral glucose tolerance test as follows: after an overnight fast, a Venflon catheter (Becton-Dickinson, Sweden) was inserted into an antecubital vein and a blood sample was taken ( $\mathrm{NaF}$ containing tube) for measurement of fasting glucose concentration in venous plasma. Immediately thereafter, the glucose concentration was measured in capillary whole blood from the third or fourth fingertip of the non-dominant hand, using Glucometer Elite ${ }^{\circledR}$ (Bayer, USA). Notably, Glucometer Elite $\otimes^{\circ}$ converts capillary whole blood values to capillary plasma values (technical data supplied by the manufacturer, Bayer, Mijdrecht, the Netherlands). Inter-coefficients of variation at fasting and $2 \mathrm{~h}$ after the glucose load were $4.5 \%$ and $9.3 \%$, respectively (19). Subsequently, a 75-g glucose load (analogous to $82.5 \mathrm{~g}$ dextrose monohydrate, Avebe, the Netherlands) in $250 \mathrm{ml}$ plain water was given. A few drops lemon juice were added for taste adjustment. Two hours after the glucose load, a venous blood sample was taken. Immediately thereafter, a capillary whole blood sample was taken from the same fingertip as with the fasting measurement. Plasma glucose was measured with the hexokinase glucose-6-phosphate dehydrogenase method (HK-G6PD method, ABX Diagnostics Glucose HK125, Montpellier, France). To measure accuracy of the capillary measurement, 39 subjects underwent two successive measurements on two different fingers, both at fasting and $2 \mathrm{~h}$ after the glucose load. Intra- and inter-coefficients of variation were $2.1 \%$ and $1.8 \%$, respectively (19). Height (in $\mathrm{cm}$ ) and body mass to the nearest $100 \mathrm{~g}$ were measured without shoes and wearing light indoor clothing. BMI was calculated in $\mathrm{kg} / \mathrm{m}^{2}$.

\subsection{Statistical Methods}

Statistical analyses were performed by SPSS 6.1.1 for Macintosh. Data are presented as mean \pm S.D. The statistical significance of differences between the glucose tolerance groups was evaluated using analysis of variance (ANOVA) and Bonferroni post hoc test. A two-sided $p$ value of less than 0.05 was considered significant. 
Correlation and linear regression analyses were performed. Results obtained using venous and capillary plasma glucose measurements were compared using the method of Bland and Altman (20) in which differences between paired measurements are plotted against the mean of each pair. To examine the agreement between capillary and venous blood glucose measurements, a cross table was made. The overall indicator kappa (k), which measures the agreement across all categories of glucose tolerance, was calculated. A value of 1 indicates perfect agreement, while a value of 0 indicates that agreement is no better than chance (21). Values larger than 0.75 may be taken to represent excellent agreement, values smaller than 0.40 may be taken to represent poor agreement and values between 0.40 and 0.75 may be taken to represent fair to good agreement.

\section{Results}

We included 207 men and 143 women (total $\mathrm{N}=350$ ) with a mean age of $58.9 \pm 7.2$ years (Table 1). Age, BMI, fasting venous glucose and $2 \mathrm{~h}$ venous glucose measurements for this subgroup did not differ from those of the total population of the CoDAM study (data not shown). Capillary plasma glucose values in all subjects combined were significantly higher than venous plasma glucose values both during the fasting state $($ difference $=$ delta $(\Delta)=0.18 \mathrm{mmol} / \mathrm{L} ; 95 \% \mathrm{Cl} \quad 0.10-0.26)$ and $2 \mathrm{~h}$ after glucose ingestion ( $\Delta=1.09 \mathrm{mmol} / \mathrm{L} ; 95 \% \mathrm{Cl} \quad 0.87-1.32)$ (Table 1). The differences between fasting capillary and venous plasma glucose levels were not significantly different between the groups (DM $\Delta=0.21 \mathrm{mmol} / \mathrm{L}$, IGT $\Delta=0.20 \mathrm{mmol} / \mathrm{L}$, NGT $\Delta=0.16$ $\mathrm{mmol} / \mathrm{L})$ (Table 1). The capillary-venous difference at $2 \mathrm{~h}$ post load glucose levels in NGT subjects $(\Delta=1.42 \mathrm{mmol} / \mathrm{L})$ was significantly different from the difference in IGT and $\mathrm{DM}$ subjects $(\Delta=0.66 \mathrm{mmol} / \mathrm{L}$ and $\Delta=0.58 \mathrm{mmol} / \mathrm{L}$, respectively $)$.

\subsection{Capillary versus venous glucose measurements}

A high correlation between capillary and venous plasma glucose values was found during fasting $(r=0.92 ; p<0.0001)$ and at $2 h$ post load $(r=0.83 ; p<0.0001)$. Regression analysis of capillary glucose measurements on venous glucose measurements in the entire group showed an intercept of $0.05(p=0.70)$ and a regression coefficient of $1.02(p<0.0001)$ for the fasting state. At 2 h post load, the intercept was $2.08(p<0.0001)$ and the regression coefficient was $0.87(p<0.00001)$. Because a high correlation coefficient does not necessarily mean that two methods agree satisfactorily, a Bland-Altman plot $(20)$ was calculated at fasting and at $2 \mathrm{~h}$ after the glucose load (Figs. 1 and 2). Differences between paired measurements have been plotted against the mean of each pair and the horizontal top and bottom lines represent the mean \pm 2 S.D., respectively.

In the fasting state, discrepancies were observed in the lower range of blood glucose values $(<4.0 \mathrm{mmol} / \mathrm{L}$ ), whereas at $2 \mathrm{~h}$ post load, discrepancies were found over the entire range of blood glucose values. Subjects with IGT and NGT had significantly higher capillary glucose concentrations than venous glucose levels, both fasting and $2 \mathrm{~h}$ post load $(p<0.05)$ (Table 1$)$. In DM, fasting, but not $2 \mathrm{~h}$ post load, capillary glucose values were significantly higher than venous glucose values. 
Table 1: Characteristics of the entire study group $(\mathrm{N}=350)$ and the three glucose tolerance categories according to classification by venous blood glucose concentrations.

\begin{tabular}{lcccc}
\hline Number $(\mathrm{N})$ & Total 350 & DM 97 & IGT 77 & NGT 176 \\
\hline Men (\%) & 59 & 69 & 60 & 53 \\
Age (years) & $58.9 \pm 7.2$ & $58.3 \pm 5.8$ & $59.8 \pm 6.9$ & $58.7 \pm 7.6$ \\
& & & \\
BMI (kg/m ${ }^{2}$ ) & $28.6 \pm 4.1$ & $30.2 \pm 4.1^{*}$ & $29.1 \pm 4.1$ & $27.9 \pm 4.0$ \\
Fasting glucose C (mmol/L) & $6.0 \pm 1.3 \dagger$ & $7.7 \pm 1.7^{*} \dagger \ddagger$ & $6.1 \pm 0.8^{*} \dagger$ & $5.4 \pm 0.7 \dagger$ \\
Fasting glucose V (mmol/L) & $5.8 \pm 1.0$ & $7.5 \pm 1.3^{*} \ddagger$ & $5.9 \pm 0.5^{*}$ & $5.3 \pm 0.4$ \\
2h Glucose C (mmol/L) & $8.7 \pm 3.4 \dagger$ & $13.7 \pm 3.9^{*} \ddagger$ & $9.4 \pm 2.6^{*} \dagger$ & $7.0 \pm 1.9 \dagger$ \\
& & & \\
2h Glucose V (mmol/L) & $7.6 \pm 3.3$ & $13.1 \pm 3.2^{*} \ddagger$ & $8.7 \pm 1.6^{*}$ & $5.6 \pm 1.2$ \\
$\begin{array}{l}\text { Delta C-V fasting (mmol/L) } \\
\text { (95\% Cl) }\end{array}$ & 0.18 & 0.21 & 0.20 & 0.16 \\
$\begin{array}{l}\text { Delta C-V 2h (mmol/L) } \\
\text { (95\% Cl) }\end{array}$ & $(0.10-0.26)$ & $(-0.08-0.51)$ & $(0.04-0.36)$ & $(0.07-0.25)$ \\
\hline
\end{tabular}

Data are mean \pm S.D.

$\mathrm{C}=$ capillary plasma glucose concentrations; $\mathrm{V}=$ venous plasma glucose concentrations

- significantly different from NGT ( $p<0.05)$

$\dagger$ significantly different from venous glucose $(p<0.05)$

$\ddagger$ significantly different from IGT $(p<0.05)$

$\S$ significantly different from DM $(p<0.05)$

\subsection{Classification of glucose tolerance status}

The 350 participating subjects were stratified by glucose tolerance status as NGT, IGT or DM, according to the 1999 WHO criteria using either venous (V) plasma glucose or capillary (C) plasma glucose concentrations (Table 2). After application of the 1999 WHO criteria for venous plasma glucose concentrations (1), the proportion of DM was 97 of $350(27.7 \%)$ subjects and that of IGT 77 of $350(22.0 \%)$ subjects. The consistency in classification between capillary and venous glucose measurements was $78 \%(k=$ $0.65, p<0.001)$. Sensitivity and specificity to diagnose DM by capillary glucose measurements were $84 \%$ and $98 \%$, respectively. Among DM subjects, 17 out of 111 subjects $(15.3 \%)$ were classified as IGT by capillary glucose criteria compared with classification by venous glucose criteria (Table 2) and thus remained glucose intolerant. Only 1 subject was classified as NGT. In subjects with NGT, 12 out of 143 subjects $(8.4 \%)$ were classified as IGT. In subjects with IGT, 48 out of 96 subjects $(50.0 \%)$ were differently categorised of which 44 were diagnosed as NGT according to capillary levels. 
Table 2: Resulting classification of glucose tolerance status in study subjects according to the 1999 WHO criteria for venous $(\mathrm{V})$ and capillary $(\mathrm{C})$ plasma concentrations.

\begin{tabular}{|c|c|c|c|c|}
\hline & $\begin{array}{l}\text { Normal glucose } \\
\text { tolerance }(V)\end{array}$ & $\begin{array}{l}\text { Impaired glucose } \\
\text { tolerance (V) }\end{array}$ & $\begin{array}{l}\text { Type } 2 \text { diabetes } \\
\text { mellitus }(V)\end{array}$ & Total (C) \\
\hline $\begin{array}{l}\text { Normal glucose } \\
\text { tolerance (C) }\end{array}$ & 131 & 12 & 0 & 143 \\
\hline $\begin{array}{l}\text { Impaired glucose } \\
\text { tolerance (C) }\end{array}$ & 44 & 48 & 4 & 96 \\
\hline $\begin{array}{l}\text { Type } 2 \text { diabetes } \\
\text { mellitus (C) }\end{array}$ & 1 & 17 & 93 & 111 \\
\hline Total (V) & 176 & 77 & 97 & 350 \\
\hline
\end{tabular}

Fig. 1: Bland and Altman plot of capillary (C) and venous (V) plasma glucose measurements in the fasting state. The horizontal top and bottom line represent \pm 2 S.D.

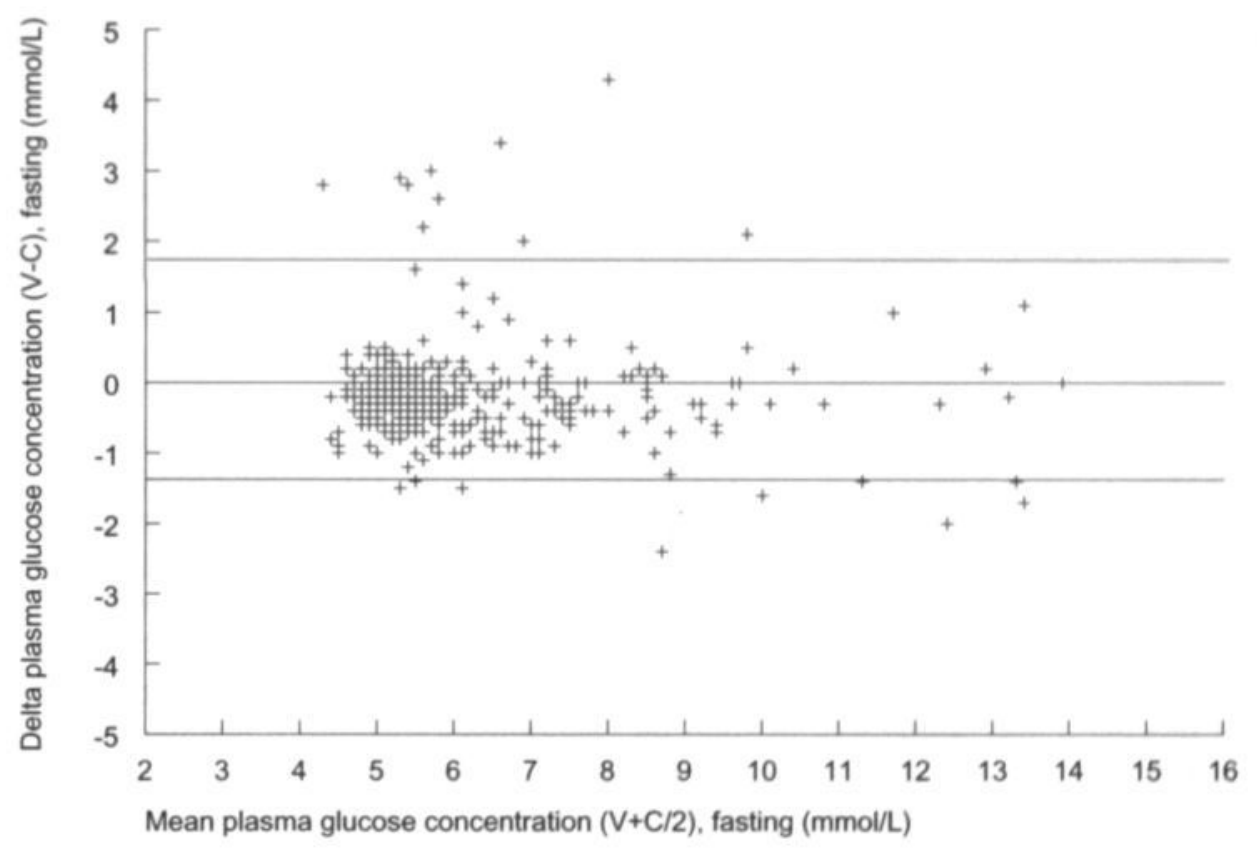


Fig. 2: Bland and Altman plot of capillary $(C)$ and venous $(V)$ plasma glucose measurements, $2 \mathrm{~h}$ post load. The horizontal top and bottom line represent \pm 2 S.D.

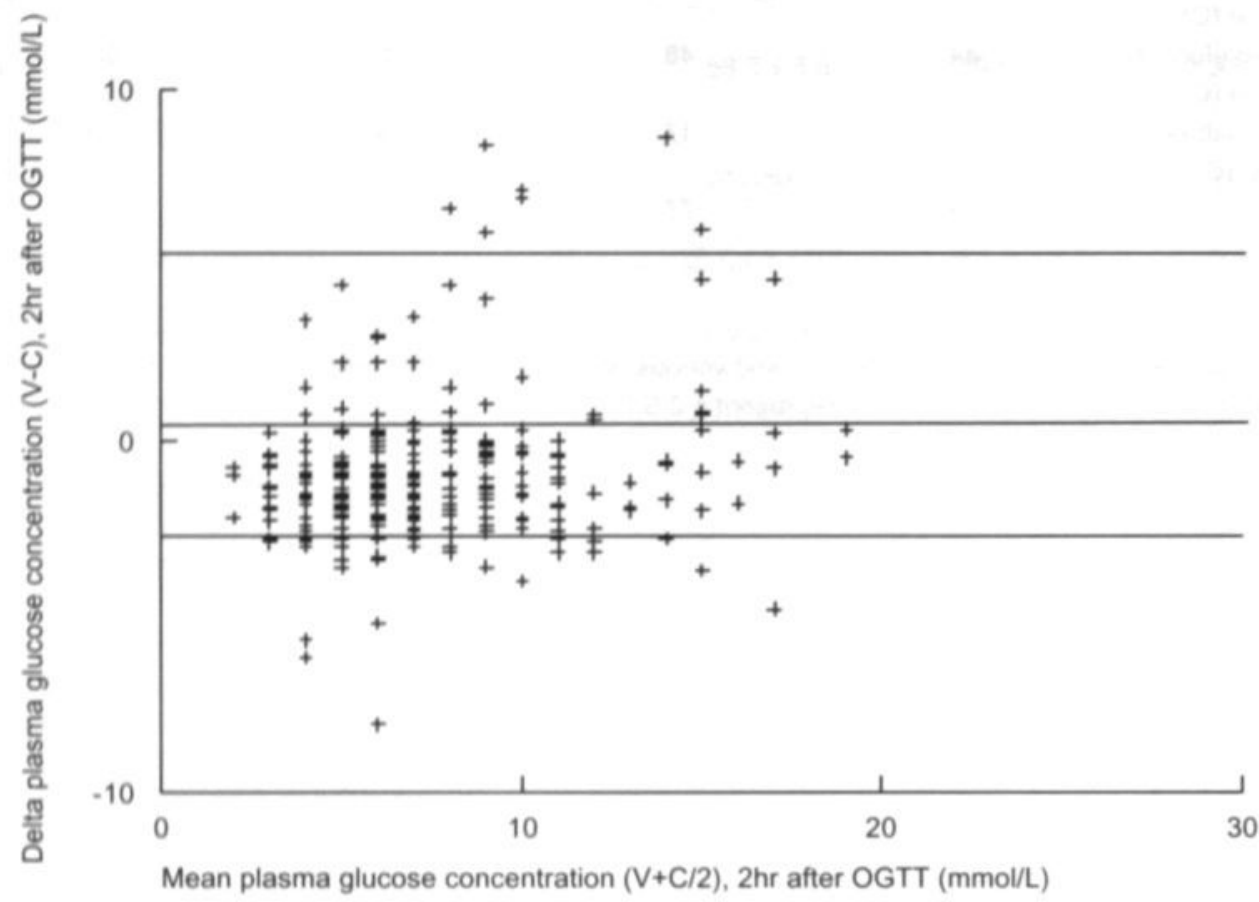

\section{Discussion}

The OGTT has been used in the diagnosis of diabetes or glucose intolerance when blood glucose levels are equivocal, during pregnancy, or in epidemiological studies (1). The OGTT in the present study had been done according to guidelines of the WHO. Nowadays, reflectance meter measurements of glucose correspond well with reference laboratory glucose measurements $(2,3)$. This report presents evidence that capillary plasma glucose measurements obtained by Glucometer Elite ${ }^{\circledR}$ are suitable for use in the screening phase of epidemiological studies to detect type 2 diabetes mellitus. A high correlation has been found between capillary and venous plasma glucose concentrations (fasting $r=0.92 ; 2 \mathrm{~h}$ post load $r=0.83$ ). Moreover, the Bland-Altman plot showed minor discrepancies in the fasting state $(<4 \mathrm{mmol} / \mathrm{L})$ between capillary and venous plasma glucose measurements, and only in the lower glucose range. In the $2 \mathrm{~h}$ post load state, discrepancies occurred over the entire range of glucose levels.

The present study found capillary plasma glucose levels to be systematically higher in the fasting state. This finding seems to contrast with those of other studies, which did not find a difference between capillary and venous glucose measurements in the fasting state $(4-7,12)$. Most of these studies however did not use a commercially available 
glucose meter and had a considerably smaller number of subjects, leaving open the possibility that significant differences may have been missed due to logistic problems or lack of statistical power. Other studies which compared and evaluated capillary and venous blood glucose measurements differed from the present study in their design (i.e. in the study of specific age groups, gender, pregnant women, in the use of self monitoring blood glucose devices, laboratory methods and randomly taken samples $(4,6,9,10,12))$. Therefore, their data may not be fully comparable with our results. The only study in which a comparable number of subjects was used as in the present study $(\mathrm{N}=207)(7)$ also found a tendency towards higher capillary plasma glucose values in the fasting state, although this did not reach statistical significance.

No significant difference existed between capillary and venous plasma glucose measurements in subjects with DM in the $2 \mathrm{~h}$ post load state. This is in contrast to findings in IGT and NGT subjects, although the delta of DM is approximately the same as for IGT. After the ingestion of glucose, insulin secretion by the pancreas is stimulated (22). Defects in insulin secretion at the level of the $\beta$ cell, and insulin resistance in muscle, can lead to the development of glucose intolerance or overt diabetes. In DM, muscle tissue is more insulin resistant than IGT and NGT (22). Such insulin resistance results in lower glucose uptake and extraction from blood and a smaller difference between venous and capillary plasma glucose measurements will therefore be measured, explaining the findings in the present study in DM subjects.

Larsson-Cohn et al. (4) and West (23) already reported different relationships between glucose concentrations in capillary and venous blood at the different time points during an oral glucose tolerance test. This information has been incorporated in the classification according to the 1999 WHO criteria, which take the differences between capillary and venous plasma glucose measurements for the different glucose tolerance groups into account. In the present study, this is shown by little disagreement found in classification according to capillary and venous plasma glucose measurements among NGT subjects, i.e. 12 of $143(8.4 \%)$. In the DM category, 18 of $111(16.2 \%)$ were potentially misclassified, but 17 of the 18 subjects were classified as IGT and thus remained glucose intolerant. Our findings were in agreement with Farrer et al. (11), who found no effect of the choice of blood sampling, venous whole blood or venous plasma, on the subsequent classification of type 2 diabetes mellitus by repeated OGTTs. In the present study however, 48 subjects of $96(50 \%)$ in the IGT category were misclassified, of which 44 subjects shifted to NGT. To some degree, the lesser agreement in IGT can be an artefact, caused by the narrow range of defined cutoff points for $2 \mathrm{~h}$ glucose concentrations in IGT. In addition, the background of IGT represents a diverse set of metabolic abnormalities including insulin secretion defects and insulin resistance, and to precisely establish IGT status remains a topic of continued discussion. With respect to future prevention programs, it is important to realize that a diagnosis of DM or NGT can be established by capillary plasma glucose. This knowledge can be used to create cost-effective inclusion schemes. It is likely that subjects with IGT will be an important target for diabetes prevention programs given the impressive results of lifestyle intervention to prevent DM $(24,25)$. Furthermore, a combination of lifestyle intervention and drug treatment has been successfully utilized in several studies (25-27). Notably, in the DPP study (28), 133,683 subjects had to be screened to enrol 3048 participants, an 1:43.9 ratio. Recently, we used capillary glucose measurements as a pre-screening tool followed by an OGTT with venous plasma glucose measurements in a lifestyle 
intervention study (29). The ratio of screened (2715) subjects and detected IGT subjects (385) subjects was 1:7.1, indicating that use of capillary measurements can result in cost-effective inclusion schemes.

In conclusion, capillary glucose measurements in normal glucose tolerant and type 2 diabetes subjects are reliable and precise, using a commercially available glucose meter. The present findings indicated that capillary plasma glucose measurements are as suitable as venous plasma glucose measurements in the diagnosis and detection of type 2 diabetes mellitus in epidemiological studies and may be cost-effective in implementation in pre-screening procedures.

\section{Acknowledgments}

This project was supported by a grant of the Netherlands Organisation for Scientific Research (940-35-034) and the Dutch Diabetes Research Foundation (98.901). We thank Ellen Lambrichs and Jos Stegen for their expert technical assistance.

\section{References}

1. World Health Organization. Definition, diagnosis and classification of diabetes mellitus and its complications. Report of a WHO Consultation. Part 1: Diagnosis and classification of diabetes mellitus. WHO Technical Report Series 1999:1-59

2. Solnica B, Naskalski JW, Sieradzki J. Analytical performance of glucometers used for routine glucose self-monitoring of diabetic patients. Clin Chim Acta 2003; 331:29-35

3. Rheney CC, Kirk JK. Performance of three blood glucose meters. Ann Pharmacother 2000; 34(3):317-21

4. Larsson-Cohn U. Differences between capillary and venous blood glucose during oral glucose tolerance tests. Scand J Clin Lab Invest 1976; 36:805-808

5. Melnik J, Potter JL. Variance in capillary and venous glucose levels during a glucose tolerance test. Am J Med Techn 1982; 48(6):543-545

6. Eriksson KF, Fex G, Trell E. Capillary-venous differences in blood glucose values during the oral glucose tolerance test. Clin Chem 1983; 29(5): 993

7. Irjala K, Koskinen P, Näntö V, Peltola O. Interpretation of oral glucose tolerance test: capillaryvenous difference in blood glucose and the effect of analytical method. Scand J Clin Lab Invest 1986; 46:307-313

8. Vallera DA, Bissell MG, Barron W. Accuracy of portable blood glucose monitoring. Effect of glucose level and prandial state. Am J Clin Pathol, Vol. 95, 247-252, 1991

9. Matthews DR, Burton SF, Bown E, et al. Capillary and venous blood glucose measurements using a direct glucosesensing meter. Diabet Med 1991; 8:875-880

10. Qiao Q, Keinänen-Kiukaanniemi S, Rajala U, Uusimäki A, Kivelä S-L. Random capillary whole blood glucose test as a screening test for diabetes mellitus in a middle-aged population. Scand J Clin Lab Invest 1995; 55:3-8

11. Farrer M, Albers CJ, Neil HAW, Adams PC, Laker MF, Alberti KGMM. Assessing the impact of blood sample type on the estimated prevalence of impaired glucose tolerance and diabetes mellitus in epidemiological surveys. Diabet Med 1995; 12:325-329

12. Kuwa $K$, Nakayama $T$, Hoshino $T$, Tominga $M$. Relationships of glucose concentrations in capillary whole blood, venous whole blood and venous plasma. Clin Chim Acta 2001; 307:187-192

13. Neely RDG, Kiwanuka JB, Hadden DR. Influence of sample type on the interpretation of the oral glucose tolerance test for gestational diabetes mellitus. Diabet Med 1990; 8:129-134

14. The Expert Committee on the Diagnosis and Classification of Diabetes Mellitus. Report of the Expert Committee on the Diagnosis and Classification of Diabetes Mellitus. Diabetes Care 1997; 20:1183-97 
15. Larsson $\mathrm{H}$, Berglund $\mathrm{G}$, Lindgàrde $\mathrm{F}$, Ahrén $\mathrm{B}$. Comparison of $A D A$ and $W H O$ criteria for the diagnosis of diabetes and glucose intolerance. Diabetologia 1998; 41:1124-1125

16. DECODE Study Group on behalf of the European Diabetes Epidemiology Study Group. Will new diagnostic criteria for diabetes mellitus change phenotype of patients with diabetes? Reanalysis of European epidemiological data. BMJ 1998; 317:371-5

17. Shaw JE, McCarty D, Zimmet PZ, De Courten M. Type 2 diabetes worldwide according to the new classification and criteria. Diabetes Care 2000; 23 Suppl. 2:B5-B10

18. De Vegt F, Nijpels G, Dekker JM, Bouter LM, Stehouwer CDA, Heine RJ. The 1997 American Diabetes Association criteria versus the 1985 World Health Organization criteria for the diagnosis of abnormal glucose tolerance. Diabetes Care 1998; 21:1686-1690

19. Bland JM, Altman DG. Measurement error proportional to the mean. BMJ 1996; 313:106

20. Bland JM, Altman DG. Statistical methods for assessing agreement between two methods of clinical measurement. Lancet 1986:307-310

21. Fleiss JL. Statistical Methods for Rates and Proportions. Wiley, New York, 1981

22. DeFronzo RA. Lilly Lecture 1987. The Triumvirate: $\beta$-Cell, Muscle, Liver. A collusion responsible for NIDDM. Diabetes 1988; 37:667-687

23. West KM. Epidemiology of Diabetes and Its Vascular Lesions. New York: Elsevier, 1978:67-68

24. Tuomilehto J, Lindström J, Eriksson JG, et al. Prevention of type 2 diabetes mellitus by changes in lifestyle among subjects with impaired glucose tolerance. N Engl J Med 2001; 344:1343-50

25. Knowler WC, Barrett-Connor E, Fowler S, et al. Reduction in the incidence of type 2 diabetes with lifestyle intervention or metformin. N Engl J Med 2002; 346:393-403

26. Chiasson J, Josse RG, Gomis R, Hanefeld M, Karasik A, Laakso M. Acarbose for prevention of type 2 diabetes mellitus: the STOR NIDDM randomised trial. Lancet 2002; 359:2072-77

27. Scheen AJ. (Info-congress. Prevention of type 2 diabetes in obese patients: first resuts with orlistat in the XENDOS study). Rev Med Liege 2002; 57(9) : 617-21

28. Fujimoto WY. Background and recruitment data for the U.S. Diabetes Prevention Program. Diabetes Care 2000; 23 Suppl 2:B11-3

29. Mensink M, Feskens EJM, Saris WHM, de Bruin TWA, Blaak EE Study on lifestyle intervention and impaired glucose tolerance Maastricht (SLIM): preliminary results after one year. Int J Obesity 2003; $27: 377-384$ 


\section{CHAPTER 5}

\section{Increased Arterial Stiffness in Recently Diagnosed Type 2 Diabetes Mellitus}

M Kruijshoop ${ }^{1}$, CJH van der Kallen ${ }^{1}$, APG Hoeks ${ }^{2}$, EH Lambrichs ${ }^{1,3}$, EJM Feskens ${ }^{4}$, EE Blaak $^{5}$ and TWA de Bruin ${ }^{1}$

${ }^{1}$ Department of Internal Medicine, Laboratory for Molecular Metabolism and Endocrinology, Cardiovascular Research Institute Maastricht (CARIM), Maastricht University, Maastricht, the Netherlands; ${ }^{2}$ Department of Biophysics, Cardiovascular Research Institute Maastricht (CARIM), Maastricht University, Maastricht, the Netherlands; ${ }^{3}$ Present address: Department of Population Genetics, Genomics \& Bioinformatics, Maastricht University, Maastricht, the Netherlands; ${ }^{4}$ Centre for Nutrition and Health, National Institute for Public Health and the Environment, Bilthoven, the Netherlands; ${ }^{5}$ Department of Human Biology, Nutrition and Toxicology Research Institute Maastricht (NUTRIM), Maastricht University, Maastricht, the Netherlands

\section{Submitted for publication}




\begin{abstract}
Patients with type 2 diabetes are at increased risk of cardiovascular disease. However, it is insufficiently clear at what point of the atherosclerosis process the acceleration occurs that is responsible for such an increased risk. Therefore, we investigated Young's elastic modulus (YEM) and intima-media thickness (IMT) in 86 subjects with recently diagnosed type 2 diabetes (within 0 to 4 years before inclusion), 88 subjects with impaired glucose tolerance and 234 control subjects with normal glucose tolerance, all selected from a population-based cohort. Arterial stiffness, measured by YEM, was significantly increased in type 2 diabetes whereas IMT was similar in all groups. In multivariable analysis, YEM was predicted by age, male gender, presence of hypertension, sagittal diameter, and total cholesterol plasma concentration. When the data were compared with similar data obtained in a collaborative cohort with subjects a decade older, a significant twofold increase in YEM and IMT was calculated comparing diabetes patients with NGT subjects. We conclude that in subjects with recently diagnosed type 2 diabetes arterial stiffness was increased before IMT-thickening had occurred. In diabetes of longer duration, both arterial stiffness and IMT were increased compared to controls, suggesting acceleration of functional and structural vessel wall abnormalities.
\end{abstract}




\section{Introduction}

Patients with type 2 diabetes rave an increased incidence of macrovascular disease, and approximately $60-70 \%$ of patients with type 2 diabetes die from atherosclerotic vascular disease such as myocardial infarction or stroke $(1,2)$. The main theory to explain the increased risk of cardiovascular disease in type 2 diabetes holds that the increase in risk is caused by an increased rate of atherosclerosis, although many questions remain unanswered. One of the main questions is at what stage of atherosclerosis development the acceleration occurs. Is this at the phase of endothelial dysfunction, arterial wall changes, plaque formation or plaque instability? Theoretical arguments that diabetes affects each of these steps have been reviewed recently (3). One of the problems to clarify this issue is that in general the time of occurrence to clinical diagnosis of type 2 diabetes is uncertain. In this report, we were able to narrow this time window to zero to four years. We recruited subjects from a population cohort (Monitoring Project for Cardiovascular Diseases (4) and its predecessor (5)) who were free of clinically diagnosed diabetes but were at high risk for this disease and participated in a diabetes screening in $1999(6,7)$.

The slow progression of the atherosclerosis process in humans has resulted in the search for surrogate markers to study determinants of atherosclerosis. Validated surrogate markers of different stages of atherosclerosis exist, i.e. intima-media thickness (IMT) and arterial stiffness (8-10). IMT measurements indicate structural changes involving hyperplasia of arterial smooth muscle cells (8), whereas arterial stiffness is considered to be a measure of early functional loss of elasticity and compliance within the vascular system (9). The aim of our study is to assess whether differences exist in IMT and Young's elastic modulus (YEM), a marker of arterial stiffness, to clarify which clinical stage of atherosclerosis development is accelerated in abnormal glucose metabolism.

\section{Methods}

\subsection{Subjects}

The Cohort study of Diabetes and Atherosclerosis Maastricht (CODAM) is a prospective, population based, cohort study in Dutch subjects who have been stratified according to glucose tolerance, i.e. normal glucose tolerance (NGT), impaired glucose tolerance (IGT), or type 2 diabetes mellitus (DM), as described in Mensink et al. (7). Subjects were recruited from a general population monitoring study in Maastricht and two other Dutch towns $(4,5)$. Inclusion criteria were: age over 40 years, and either a Body Mass Index $(B M I)>25 \mathrm{~kg} / \mathrm{m}^{2}$, a positive family history of DM, a history of gestational diabetes, use of antihypertensive medication, a postprandial blood glucose $>6.0 \mathrm{mmol} / \mathrm{L}(108 \mathrm{mg} / \mathrm{dL})$, or glucosuria. Combinations of these separate inclusion criteria were allowed. Exclusion criteria were self-reported diabetes and glucosuria 
during the previous screening in 1998 in the monitoring study $(4,5)$, the use of medication that affects glucose metabolism and non-Caucasian ethnicity. The local Medical Ethical Committee of the University of Maastricht and University Hospital Maastricht approved the study. All participants gave written informed consent.

\subsection{CODAM study}

From February 1999 until March 2000, 2715 subjects identified through the Monitoring Project for Cardiovascular Diseases (4) and Chronic Diseases (5) participated in the glucose tolerance and diabetes screening phase of the CODAM study and the Study on Lifestyle-intervention and Impaired Glucose Tolerance Maastricht (SLIM), a lifestyle intervention study directed at a healthy diet and increased physical activity (7). The screening phase and the subsequent classification according to the 1999 WHO criteria for glucose tolerance (11) were described by Mensink et al. (7). Participants were invited for inclusion in either the CODAM study $(N=574)(6)$ or the SLIM study $(N=114)$ (7) and underwent a second oral glucose tolerance test (OGTT) with venous plasma glucose measurements in order to establish their glucose tolerance status. Eventually, a total of 574 subjects were included in the CODAM cohort study. These represented 147 recently diagnosed type 2 diabetes (100 newly diagnosed and 47 additional subjects diagnosed between one and four years prior to the study), 129 had IGT (104 IGT, 25 IFG), and 298 were NGT subjects.

\subsection{Measurements}

Subjects visited the Clinical Research Unit twice with a time interval varying between 2 weeks and 10 months. Lipid lowering medication was stopped 10 days before the first visit and all other medication was stopped the day before the visits. At the first visit, glucose tolerance was measured by a standard 75-g OGTT and defined according to the 1999 WHO criteria (11). Before OGTT, after an overnight fast, a blood sample was taken for measurement of fasting plasma glucose concentrations, insulin, HbA1c, total cholesterol, HDL- and LDL-cholesterol, triglycerides and non-esterified fatty acids (NEFA's) $(7,11-13)$. Blood pressure was measured twice on the right arm in supine position after 5 minutes of rest (Maxi Stable 3, Speider \& Keller, Germany). Hypertension was defined as systolic blood pressure (SBP)/diastolic blood pressure (DBP) $\geq 140 / 90$ (14), or use of antihypertensive medication. Height (in $\mathrm{cm}$ ) and body weight to the nearest 100 grams were measured without shoes and wearing light indoor clothing. BMI was calculated by dividing weight by height in $\mathrm{kg} / \mathrm{m}^{2}$. At the second visit, sagittal diameter (in $\mathrm{mm}$ ) was measured at the level of the spina iliaca anterior superior by a slide gauge with the subject in supine position on a hard couch with the subjects hands folded under the head. Blood pressure was measured twice in the same way as described in Visit 1. The average of the SBP and DBP measurements of both visits was calculated. History of cardiovascular disease (CVD) was registered. Visit 2 also comprised the ultrasound measurements as described below. 


\subsection{Ultrasound Procedure}

Carotid intima-media thickness (IMT) was measured with ultrasound in M-mode (Ultramark 4+, ATL, Bothel, Washington, USA) by a linear array transducer of $7.5 \mathrm{MHz}$ positioned perpendicular to the common carotid artery in 7 consecutive repeated measurements as described before (15). When measurements were obtained from one side only, the median value of that side was used in the analysis. The intra-observer coefficient of variation was $3.7 \%$ (observer 1) as determined in 5 subjects and $4.0 \%$ (observer 2) as determined in 7 subjects. SBP and DBP were measured with a validated automatic oscillometric blood pressure device (OMRON 705CP, Nieuwegein, the Netherlands) on the right arm before the procedure, and after the third and seventh measurement. The average of all SBP and DBP measurements during the procedure was calculated. Brachial pulse pressure (PP) was defined as average SBP minus average DBP and was only used to calculate Young's elastic modulus. Brachial mean arterial pressure (MAP) was calculated as DBP + (PP / 3).

Young's elastic modulus (YEM) was assessed with an Ultramark 4+ (Ultramark 4+, ATL, Bothel, Washington, USA) and with the use of an echo wall tracking system at the same position in the common carotid artery (CCA) as used in IMT measurements. The wall tracking system measures non-invasively the diastolic diameter $\mathrm{d}$ and distension $\Delta d$, the change in diameter as function of time $(16,17)$. YEM is defined as follows:

$\mathrm{YEM}=\mathrm{d} /(\mathrm{IMT} *((\Delta \mathrm{A} / \mathrm{A}) / \mathrm{PP})) \quad(\mathrm{MPa})$,

where $A$ is the diastolic lumen area (calculated by $\left.p^{*}\left(0.5^{*} d\right)^{2}\right), \Delta A$ the change in crosssectional area from diastole to systole (calculated by $\left.p^{*}\left((d+\Delta d)^{2}-d^{2}\right) / 4\right)$, and IMT is the IMT value resulting from the IMT measurement (16). Higher values of YEM are an indication of higher arterial stiffness. All measurements were repeated seven times at both left and right common carotid artery. Measurements were repeated when the intrameasurement of diameter showed a standard deviation of more than $1 \%$ and of distension showed a standard deviation of more than $10 \%$. The diameters and distensions of the right and the left common carotid artery were different between DM and NGT subjects (data not shown). We used the average of the left common carotid artery diameter and distension in analyses, because of the small number of missing values on this side, and few subjects had the left hand side as the dominant side $(6.3 \%)$.

Carotid ultrasound measurements were obtained in $86.9 \%$ of all 574 subjects. Both IMT and YEM measurements were available in 408 subjects. Common reasons for missing data or subjects were cardiac arrhythmia, longitudinal or oscillating movements of the carotid artery, (neck) obesity, or logistic problems.

\subsection{Statistical analyses}

Statistical analyses were done by SPSS 9.0 for Windows. Differences between included and excluded subjects, and between subjects newly diagnosed with diabetes and subjects diagnosed between one and four years prior to this study, were examined with a t-test. Plasma triglyceride and insulin concentrations, and YEM had a skewed distribution and were log-transformed to satisfy conditions of normality. In the tables however, their untransformed values have been used. Age and gender adjusted tests for trend in continuous variables were calculated from linear regression analysis. 
Differences in dichotomous variables were calculated by Chi-square. The yearly increments in IMT and YEM were calculated in DM and NGT subjects by linear regression analysis with age as the independent variable (range $42-72$ years). The CODAM study and the Hoorn study (12) are part of a collaborative study and have similar protocols for IMT measurements. Therefore, estimations can be made of the yearly increments in IMT using the results of the Hoorn study (mean age 69 years) (12) and the present data (mean age 59 years) based on a mean age difference of 7.0 years for DM and 11.4 years for NGT subjects. In addition, to investigate determinants of IMT and YEM, regression analyses were carried out for each potential determinant adjusting for age and gender. Thereafter, multiple backward linear regression analyses were done with the variables that were significant in the first set $(p<0.05)$, and age and the dichotomous variables gender, smoking and hypertension were entered in the multivariate model. We controlled for glucose tolerance (DM, IGT, NGT) by including dummy variables in the analyses. The best equation was selected by using backward elimination analysis (dummy variables were kept in the equation regardless of significance of their $ß$ ).

\section{Results}

The characteristics of the study groups are listed in Table 1. IMT and YEM were measured in 261 men and 147 women, with a mean age of $58.3 \pm 7.0$ years and a mean BMI of $27.8 \pm 3.7 \mathrm{~kg} / \mathrm{m}^{2}$. There were no differences between the groups in gender, smoking habits, history of self-reported cardiovascular disease (CVD) and total cholesterol concentration. Differences in metabolic characteristics were generally as expected. The use of antihypertensive medication was two times higher in DM subjects compared to NGT subjects $(48.8 \%$ vs. $22.7 \%$; $p<0.05)$ and the same was found for lipid lowering medication (DM $30.2 \%$; NGT 14.5\%; p<0.05). Notably, the common carotid artery IMT, adjusted for age and gender, was also similar between the groups.

When subjects with DM were split in newly diagnosed (DMO) and diagnosed between one and four years prior to the study (DM1-4), differences were found in height, HbA1c, fasting glucose concentration, total and LDL cholesterol after adjustment for age and gender. No differences were found in IMT. After additional adjustment for hypertension, YEM became significantly different between DMO and $\mathrm{DM} 1-4,1.01 \mathrm{MPa}$ and $0.79 \mathrm{MPa}$, respectively $(\mathrm{p}=0.043)$. Lipid lowering medication was used more frequent in the DM1-4 subjects compared to DM0 subjects, i.e. $53.3 \%$ versus $17.9 \%$, respectively. Also, antihypertensive medication was more frequently used by the DM1-4 subjects, i.e. $70 \%$ compared to $37.5 \%$ in DM0 subjects, respectively. This was predominantly caused by a more frequent use of ACE inhibitors, diuretics and angiotensin antagonists. No differences were found in gender, smoking, or self-reported CVD. 


\subsection{Intima-media thickness}

The age-related IMT increase in subjects with diabetes or NGT was estimated by data from the CODAM study and the Hoorn study (12), and is shown in Table 2. In the CODAM study, the IMT increase per year of age was similar between DM and NGT subjects, $0.003 \mathrm{~mm}$ and $0.004 \mathrm{~mm}$, respectively. The interobserver variability in IMT between the observer of the Hoorn study and our CODAM study was $7.8 \%$ for IMT, $9.8 \%$ for distension, and $4.0 \%$ for diameter for 12 subjects on two occasions, making comparison plausible. The value for IMT in NGT subjects was $0.69 \pm 0.15 \mathrm{~mm}$ in our CODAM study and $0.83 \pm 0.16 \mathrm{~mm}$ in the Hoorn study (12). Considering the mean age difference of $11.4 \mathrm{y}$ between NGT subjects from both studies, this resulted in an estimated IMT increment of $0.012 \mathrm{~mm}$ per year of age (Table 2). In DM, IMT was $0.71 \pm$ $0.17 \mathrm{~mm}$ in CODAM and $0.88 \pm 0.16 \mathrm{~mm}$ in the Hoorn study (12). Considering a mean age difference of $7.0 \mathrm{y}$ between DM subjects, the increment in IMT is estimated at $0.024 \mathrm{~mm}$ per year of age in diabetes (Table 2). This estimated age-related IMT progression in diabetes represented an acceleration by a factor 2 compared to that in NGT subjects $(p<0.05)$.

Investigating predictive determinants for IMT in our population, we carried out backward multiple linear regression analyses with the variables that were significant in an earlier step $(p<0.05)$ as well as with the variables age, gender, smoking. hypertension, and glucose tolerance status. This showed that a significant part of the variance in IMT was predicted by left carotid diameter $(12.4 \%)$ and by PP $(0.9 \%)$. The presence of IGT, DM, or fasting plasma insulin did not significantly contribute to the prediction of IMT (Table 3).

\subsection{Arterial stiffness}

YEM was significantly higher in DM subjects compared to NGT subjects after adjustment for age and gender (Table 1). After additional adjustments for hypertension, the difference remained statistically significant $(p=0.037)$. The increase in YEM per year of age in our CODAM study was similar in DM and NGT subjects, $0.019 \mathrm{MPa}$ and 0.022 MPa per year, respectively. Table 2 shows the estimated increase in YEM per year of age in DM subjects compared to NGT subjects when comparing data from the CODAM and the Hoorn study. The data point at a significant acceleration in arterial stiffness in DM subjects at older age by a factor two (DM $0.022 \mathrm{MPa}$ per year of age vs. NGT $0.011 \mathrm{MPa}$ per year of age; $\mathrm{p}<0.05$ ).

In order to investigate predictive determinants for YEM in our population, we did backward multiple regression analyses with variables that were significant in an earlier step $(p<0.05)$ as well as with the variables age, gender, smoking, hypertension, and glucose tolerance status. This showed that a significant part of the variance of YEM was predicted by the variables age $(16.7 \%)$, the presence of hypertension $(4.9 \%)$, male gender $(3.0 \%)$, sagittal diameter $(1.3 \%)$ and total cholesterol concentration $(1.6 \%)$, resulting in a $27.5 \%$ explained variance of YEM. The presence of DM, IGT, or fasting insulin concentration did not significantly contribute to the prediction of YEM (Table 3). 
Table 1: Subject characteristics according to glucose tolerance status. Age and gender adjusted tests for trend in continuous variables were calculated from linear regression analysis.

\begin{tabular}{|c|c|c|c|c|}
\hline & $\begin{array}{c}\text { DM } \\
(\mathrm{N}=86)\end{array}$ & $\begin{array}{c}\text { IGT } \\
(\mathrm{N}=88)\end{array}$ & $\begin{array}{c}\text { NGT } \\
(\mathrm{N}=234)\end{array}$ & p-value ${ }^{a}$ \\
\hline Age (years) & $60.1 \pm 6.5$ & $58.1 \pm 6.4$ & $57.7 \pm 7.4$ & 0.008 \\
\hline BMI $\left(\mathrm{kg} / \mathrm{m}^{2}\right)$ & $29.3 \pm 3.8$ & $28.3 \pm 3.6$ & $27.0 \pm 3.4$ & $<0.001$ \\
\hline Sagittal diameter (mm) & $222.7 \pm 30.6$ & $214.4 \pm 33.5$ & $197.8 \pm 27.4$ & $<0.001$ \\
\hline HbA1c (\%) & $6.8 \pm 1.2$ & $5.8 \pm 0.4$ & $5.6 \pm 0.4$ & $<0.001$ \\
\hline Fasting glucose $(\mathrm{mmol} / \mathrm{l})$ & $7.9 \pm 1.9$ & $5.9 \pm 0.5$ & $5.3 \pm 0.4$ & $<0.001$ \\
\hline IMT (mm) & $0.71 \pm 0.17$ & $0.71 \pm 0.14$ & $0.69 \pm 0.15$ & 0.46 \\
\hline Carotid diameter $(\mathrm{mm})$ & $7.86 \pm 1.08$ & $7.67 \pm 1.02$ & $7.40 \pm 0.95$ & 0.005 \\
\hline YEM $^{b}(\mathrm{MPa})$ & $0.94 \pm 0.54$ & $0.81 \pm 0.49$ & $0.74 \pm 0.50$ & 0.004 \\
\hline Total cholesterol $(\mathrm{mmol} / \mathrm{l})$ & $5.25 \pm 1.28$ & $5.23 \pm 0.93$ & $5.20 \pm 0.94$ & 0.73 \\
\hline HDL-cholesterol (mmol/l) & $1.08 \pm 0.29$ & $1.16 \pm 0.32$ & $1.27 \pm 0.35$ & $<0.001$ \\
\hline Triglycerides $^{\mathrm{b}}(\mathrm{mmol} / \mathrm{l})$ & $1.98 \pm 1.28$ & $1.65 \pm 0.81$ & $1.31 \pm 0.56$ & $<0.001$ \\
\hline $\mathrm{SBP}(\mathrm{mmHg})$ & $147.4 \pm 18.7$ & $142.7 \pm 20.1$ & $134.4 \pm 18.6$ & $<0.001$ \\
\hline $\mathrm{DBP}(\mathrm{mmHg})$ & $84.1 \pm 9.7$ & $84.0 \pm 9.7$ & $79.7 \pm 8.5$ & $<0.001$ \\
\hline Pulse pressure $(\mathrm{mmHg})$ & $63.2 \pm 15.8$ & $58.7 \pm 15.1$ & $54.7 \pm 14.1$ & $<0.001$ \\
\hline MAP $(\mathrm{mmHg})$ & $105.2 \pm 11.1$ & $103.6 \pm 12.1$ & $98.0 \pm 10.9$ & $<0.001$ \\
\hline Men (\%) & 70.9 & 64.8 & 61.1 & - \\
\hline Current smoking (\%) & 11.6 & 14.8 & 15.0 & - \\
\hline History of self-reported CVD & 21.4 & 23.3 & 19.4 & $\cdot$ \\
\hline
\end{tabular}

"p-value is age and gender adjusted; ${ }^{b}$ log-transformed; Data are given as mean \pm SD or percentages; IMT = intima-media thickness, $\mathrm{YEM}=$ Young's elastic modulus; $\mathrm{SBP}=$ systolic blood pressure; $\mathrm{DBP}=$ diastolic blood pressure; $\mathrm{MAP}=$ mean arterial pressure; $\mathrm{CVD}=$ cardiovascular disease 
Table 2: Estimated increment in IMT and YEM per year of age in subjects with diabetes (DM) and normal glucose tolerance (NGT). Data were from the present study (CODAM study) and the Hoom study (12).

CODAM study ${ }^{2} \quad$ Hoorn study $\quad$ Increase per year ${ }^{b}$

\begin{tabular}{|c|c|c|c|c|}
\hline $\mathrm{DM}$ & IMT (mm) & $\begin{array}{c}0.71 \pm 0.17 \\
(\mathrm{~N}=86)\end{array}$ & $\begin{array}{c}0.88 \pm 0.16^{c} \\
(\mathrm{~N}=301)\end{array}$ & 0.024 \\
\hline NGT & IMT (mm) & $\begin{array}{c}0.69 \pm 0.15 \\
(\mathrm{~N}=234)\end{array}$ & $\begin{array}{c}0.83 \pm 0.16^{c} \\
(\mathrm{~N}=278)\end{array}$ & 0.012 \\
\hline DM & YEM (MPa) & $\begin{array}{c}0.94 \pm 0.54 \\
(\mathrm{~N}=86)\end{array}$ & $\begin{array}{c}1.10 \pm 0.65^{c} \\
(\mathrm{~N}=301)\end{array}$ & 0.022 \\
\hline NGT & YEM (MPa) & $\begin{array}{c}0.74 \pm 0.50 \\
(\mathrm{~N}=234)\end{array}$ & $\begin{array}{c}0.87 \pm 0.44^{c} \\
(\mathrm{~N}=278)\end{array}$ & 0.011 \\
\hline
\end{tabular}

\footnotetext{
" increase per year of age: $0.003 \mathrm{~mm}$ IMT in DM, $0.004 \mathrm{~mm}$ IMT in NGT; 0.019 MPa YEM in DM and 0.022 MPa YEM in NGT; ${ }^{b}$ age difference between CODAM and Hoom study: DM $=7.0$ years; NGT $=11.4$ years; ${ }^{\circ}$ significantly different from data CODAM by $t$-test $(p<0.05)$; Data are given as mean \pm SD.
}

Table 3: Results of backward multiple regression analysis of IMT and YEMP

\begin{tabular}{lcccccc}
\hline & \multicolumn{3}{c}{ IMT } & & \multicolumn{3}{c}{ YEM } \\
& & $(\mathrm{N}=408)$ & & & $(\mathrm{N}=400)$ & \\
\hline Diameter & stand $\beta$ & $\mathrm{p}$ & $\mathrm{r}^{2}$ & stand $\beta$ & $\mathrm{p}$ & $\mathrm{r}^{2}$ \\
PP & 0.319 & $<0.001$ & 0.12 & - & - & - \\
Age & 0.101 & 0.045 & 0.009 & - & - & - \\
Sagittal Diameter & - & - & - & 0.332 & $<0.001$ & 0.17 \\
Cholesterol & - & - & - & 0.104 & 0.032 & 0.013 \\
Hypertension & - & - & - & 0.123 & 0.005 & 0.016 \\
Gender & - & - & - & 0.169 & $<0.001$ & 0.05 \\
IGT & - & - & - & -0.158 & 0.001 & 0.03 \\
DM & 0.009 & 0.85 & - & 0.022 & 0.64 & - \\
Fasting insulin & -0.035 & 0.48 & - & 0.071 & 0.15 & - \\
\hline
\end{tabular}

" log-transformed; Results are expressed as standardized $B$ and adjusted $\mathrm{r}$-square; IMT = intima-media thickness; YEM = Young's elastic modulus; $P$ P = pulse pressure; Gender: $0=$ male, $1=$ female; $1 G T$ = impaired glucose tolerance; $\mathrm{DM}=$ type 2 diabetes mellitus

\section{Discussion}

The present cohort enrolled subjects who were stratified according to their recently established glucose tolerance status as DM, IGT, or NGT. Remarkably, IMT was similar among the three glucose (in)tolerant categories. An apparent acceleration seems to 
occur in IMT thickening in subjects with DM when data are used from a similar cohort study with subjects who were a decade older and included subjects with diabetes of longer duration. Main predictors of IMT are carotid artery diameter and PP. Arterial stiffness, represented by YEM, was already increased in recently diagnosed DM subjects compared to NGT subjects whereas IGT showed intermediate stiffness. Predictors of YEM are age, male gender, presence of hypertension, sagittal diameter and total cholesterol.

A remarkable finding in the present study is that IMT was similar in DM, IGT and NGT subjects. In agreement with our results, a recent study by Hunt et al. (18) found that carotid IMT was similar in subjects who developed DM or subjects who remained free of diabetes during a prospective study. In response to increased luminal diameter and wall stress caused by factors such as hypertension and arterial stiffening, IMT thickening will decrease wall stress (Law of Laplace). In agreement with this theory, we could establish that carotid diameter and pulse pressure, but not the pre-diabetic state or DM, were independent predictors of IMT in the present study. These variables predicted $13.3 \%$ of the variance in IMT indicating that other factors, e.g. inflammatory or genetic markers (19), also contribute to IMT. Furthermore, our findings suggest that acceleration occurs in IMT thickening during manifest diabetes. This supports the finding in literature that IMT is increased in longstanding DM $(20,21)$. Also, we found no differences in CODAM between DM and NGT in self-reported histories of cardiovascular events (including prior myocardial infarction, any other serious heart condition, stroke, brain haemorrhage, or narrowing of blood vessels of the viscerae or legs). These findings suggest that a substantial part of the increase in IMT can occur during the DM state, and it should therefore be possible to prevent medical suffering from cardiovascular events in IGT and DM subjects, when detected in time and treated for the correct risk factors. These risk factors are not fully known at present, but there is evidence that acceleration in IMT during diabetes is associated with clustering of risk factors including insulin resistance, obesity, hyperlipidemia, and hypertension (metabolic syndrome) (22), chronic hyperglycemia including Amadori adducts and advanced glycation products $(12,23,24)$, inflammation, and genes that act in a diabetes background (19).

Arterial stiffness, represented by YEM, was increased in our recently diagnosed DM subjects. Furthermore, we showed that the age-related increase in YEM is accelerated in DM subjects compared to NGT subjects. YEM was mainly predicted by age and the presence of hypertension. With ageing, the increase in large artery stiffness is related to the degree of mechanical stress that results in fragmentation and disruption of elastic lamellae and derangement of the orderly structure of the elastic laminae of the vessel wall, which changes the collagen to elastin ratio (17). Furthermore, sustained hypertension can result in accelerated arterial degeneration and to prematurely occurring structural changes similar to those seen in ageing. It is of interest that YEM was also predicted by sagittal diameter, a surrogate measure of visceral obesity and related to cardiovascular risk (25), and total cholesterol. A $27.5 \%$ of the variance in YEM was explained by these variables, which indicates that the largest part of YEM is associated with other variables, not measured in the present study. Few data have been published on the relation between obesity and arterial stiffness (26). In agreement 
with the present findings, Hegazi et al. (27) showed that abdominal adiposity was a strong determinant of arterial stiffness in type 2 diabetes. The relationship between arterial stiffness and total cholesterol has not been fully elucidated however. To our knowledge, only one study has found a positive relation between plasma total cholesterol and aortic stiffness (28). When subjects with DM were classified as newly diagnosed diabetes (DMO) or diagnosed with diabetes between one and four years prior to the study (DM1-4), no differences were found between selfreported CVD, and YEM was significantly decreased in DM1-4. It has been shown that certain antihypertensives, such as nitrates, ACE inhibitors and diuretics, can prevent collagen accumulation and therefore decrease arterial stiffness (29). Although lipid-lowering medication was also more frequently used by subjects with DM1-4, data about an effect on arterial stiffness is lacking. These data suggest that treatment of hypertension may prevent future events in subjects with type 2 diabetes.

A strength of this study is that ultrasound measurements were done at a single point at the cmmon carotid artery and were repeated at least 5 times to keep the inaccuracy of the measurement of IMT, diameter and distension within acceptable range. Since YEM is calculated from IMT, diameter and distension $(16,17)$, this procedure enlarges the discriminative power and keeps the inaccuracy of YEM within acceptable range. Therefore, relevant vessel wall properties to assess arterial changes could be described in the present report $(16,17)$. Furthermore, we could narrow the time window of undiagnosed type 2 diabetes to zero to four years prior to the study. Although blood pressure measured at the brachial artery can deviate substantially from that at the carotid artery (17), use of brachial PP should not lead to a different conclusion since over- or underestimation of YEM by using brachial PP has been the same in all subjects. Because results of the present study could be analysed crosssectionally only, estimations were made using data from a similar study, the Hoorn study (12). Whether the estimations of IMT and YEM acceleration do occur in diabetes, remains to be determined by future follow up results.

In summary, arterial stiffness, measured as YEM, was significantly increased in subjects with recently diagnosed type 2 diabetes whereas IMT was normal. The results suggest that abdominal obesity contributed to the increased arterial stiffness in diabetes, possibly via an indirect effect on hypertension. When the data were compared with similar data of a cohort with subjects a decade older, a significant two-fold acceleration had occurred in YEM and IMT in diabetes. The present findings suggest that optimism is justified to prevent functional and structural arterial wall abnormalities ultimately resulting in cardiovascular events in DM. Hyperglycemia may have a direct effect upon the rate of IMT thickening, but the present results suggest that it gains significance in combination with other risk factors such as hypertension. Follow up results are needed to confirm the estimations of IMT and YEM acceleration in diabetes as well as the possible prevention of future cardiovascular events by certain antihypertensive or lipid-lowering medication or lifestyle intervention.

Acknowledgments. This project was supported by a grant of the Netherlands Organisation for Scientific Research (nr 940-35-034) and the Dutch Diabetes Research Foundation (98.901). The monitoring projects were financially supported by the Dutch 
Ministry of Welfare, Public Health and Culture. We thank the employees of the laboratories in Maastricht, Amsterdam and Rotterdam for their expert technical assistance.

\section{References}

1. The Expert Committee on the Diagnosis and Classification of Diabetes Mellitus. Report of the Expert Committee on the Diagnosis and classification of diabetes mellitus. Diabetes Care 2003; 26 : S5-S20

2. Laakso M, Lehto S. Epidemiology of macrovascular disease in diabetes. Diabetes Rev 1977; 5: 294-315

3. Creager MA, Lüscher TF, Cosentino F, Beckman JA. Diabetes and Vascular Disease.

Pathophysiology, clinical consequences, and medical therapy: Part I. Circulation 2003; 108: 1527 1532

4. Van Dam RM, Grievink L, Ocke MC, Feskens EJ. Patterns of food consumption and risk factors for cardiovascular disease in the general Dutch population. Am J Clin Nutr 2003; 77:1156-63

5. Seidell JC, Verschuren WMM, Kromhout D. Prevalence and trend of obesity in The Netherlands 1987-1991. Int J obes 1995; 19: 924-927

6. Kruijshoop M, Feskens EJM, Blaak EE, de Bruin TWA. Validation of capillary glucose measurements to detect glucose intolerance or type 2 diabetes mellitus in the general population: the CoDAM study. Clinica Chimica Acta 2004; 341: 33-40

7. Mensink M, Corpeleijn E, Feskens EJM, Kruijshoop M, Saris WHM, de Bruin TWA, Blaak EE. Study on lifestyle-intervention and impaired glucose tolerance Maastricht (SLIM): design and screening results. Diabetes Res Clin Pract 2003; 61: 49-58

8. Hodis HN, Mack WJ, LaBree L, Selzer RH, Liu CR, Liu CH, Azen SP. The role of carotid arterial intima-media thickness in predicting clinical coronary events. Ann Intern Med 1998; 128: 262-269

9. Arnett DK, Evans GW, Riley WA. Arterial stiffness: a new cardiovascular risk factor? Am J Epidemiol 1994; 140: 669-682

10. Bots ML, Dijk JM, Oren A, Grobbee DE. Carotid intima-media thickness, arterial stiffness and risk of cardiovascular disease: current evidence. J Hypertens 2002; 20: 2317-2325

11. World Health Organization: Definition, diagnosis and classification of diabetes mellitus and its complications. Report of a WHO Consultation. Part 1: Diagnosis and classification of diabetes mellitus. WHO Technical Report Series 1999; 1-59

12. Henry RMA, Kostense PJ, Spijkerman AMW, Dekker JM, Nijpels G, Heine RJ, Kamp O, Westerhof N. Bouter LM, Stehouwer CDA. Arterial stiffness increases with deteriorating glucose tolerance status. The Hoorn Study. Circulation 2003; 107: 2089-2095

13. Friedewald WT, Levy R. Fredrickson DS. Estimation of concentration of LDL cholesterol without the use of preparative ultracentrifuge. Clin Chem 1972; 18; 499

14. The sixth report of the Joint National Committee on prevention, detection, evaluation, and treatment of high blood pressure. Arch Intern Med 1997; 157: 2413-2446

15. Keulen ET, Kruijshoop M, Schaper NC, Hoeks AP, de Bruin TW. Increased intima-media thickness in familial combined hyperlipidemia associated with apolipoprotein B. Arterioscler Thromb Vasc Biol 2002; 22: 283-288

16. Van Bortel LM, Duprez D, Starmans-Kool MJ, Safar ME, Giannattasio C, Cockcroft J, Kaiser DR, Thuillez C. Clinical applications of arterial stiffness, Task Force III: recommendations for user procedures. Am J Hypertens 2002; 15: 445-452

17. Benetos A, Asmar R, Gautier S, Salvi P. Safar M. Heterogeneity of the arterial tree in essential hypertension: a noninvasive study of the terminal aorta and the common carotid artery. J Hum Hypertens 1994; 8: 501-507 
18. Hunt KJ, Williams K, Rivera D, O'Leary DH, Haffner SM, Stern MP, Gonzalez Villalpando C. Elevated carotid artery intima-media thickness levels in individuals who subsequently develop type 2 diabetes. Arterioscler Thromb Vasc Biol 2003; 23: 1845-1850

19. Dwyer JH, Allayee H, Dwyer KM, Fan J, Wu H, Mar R, Lusis AJ, Mehrabian M. Arachidonate 5lipoxygenase promoter genotype, dietary arachidonic acid, and atherosclerosis. N Engl J Med 2004; 350: 29-37

20. Temelkova-Kurktschiev TS, Koehler C, Leonhardt W, Schaper F, Henkel E, Siegert G, Hanefeld M Increased intimal-medial thickness in newly detected type 2 diabetes: risk factors. Diabetes Care 1999; 22: 333-338

21. Bonora E, Tessari R, Micciolo R, Zenere M, Targher G, Padovani R, Falezza G, Muggeo M. Intimal-medial thickness of the carotid artery in nondiabetic and NIDDM patients. Relationship with insulin resistance. Diabetes Care 1997; 20: 627-631

22. Kannel WB, McGee DL. Diabetes and cardiovascular disease. The Framingham study. JAMA 1979; 241: 2035-2038

23. Thomas GN, Chook P, Qiao M, Huang XS, Leong HC, Qelermajer DS, Woo KS. Deleterious impact of "high normal" glucose levels and other metabolic syndrome components on arterial endothelial function and intima-media thickness in apparently healthy Chinese subjects: The CATHAY Study. Arterioscler Thromb Vasc Biol 2004: 24: 1-5

24. Di Mario U, Pugliese G. 15th Golgi Lecture: from hyperglycaemia to the dysregulation of vascular remodelling in diabetes. Diabetologia 2001; 44: 674-692

25. Ohrvall M, Berglund L, Vessby B. Sagittal abdominal diameter compared with other anthropometric measurements in relation to cardiovascular risk. Int J Obes Relat Disord 2000; 24: 497-501

26. Resnick LM, Militianu D, Cunnings AJ, Pipe JG, Evelhoch JL, Soulen RL. Direct magnetic resonance determination of aortic distensibility in essential hypertension. Hypertension 1997; 30: 654-659

27. Hegazi RAF, Sutton-Tyrrell K, Evans RW, Kuller LH, Belle S, Yamamoto M, Edmundowicz D, Kelley DE. Relationship of adiposity to subclinical atherosclerosis in obese patients with type 2 diabetes. Obes Res 2003; 11: 1597-1605

28. Kontopoulos AG, Athyros VG, Pehlivanidis AN, Demitriadis DS, Papageorgiou AA, Boudoulas H. Long-term treatment of atorvastatin on aortic stiffness in hypercholesterolaemic patients. Curr Med Res Opin 2003; 19: 22-27

29. Van Bortel LMAB, Struijker-Boudier HAJ, Safar ME. Pulse pressure, arterial stiffness, and drug treatment of hypertension. Hypertension 2001; 38: 914-921 


\section{CHAPTER 6}

\section{Increased Pulse Pressure is Associated with Metabolic Syndrome and Type 2 Diabetes}

Margriet Kruijshoop ${ }^{a}$, Carla JH van der Kallen ${ }^{a}$, Hans Jansen ${ }^{b}$, Ellen H Lambrichs ${ }^{a, c}$, Edith JM Feskens ${ }^{d}$, and Tjerk WA de Bruin ${ }^{a}$

a Department of Internal Medicine, Laboratory for Molecular Metabolism and Endocrinology, Cardiovascular Research Institute Maastricht (CARIM), Maastricht University, Maastricht, the Netherlands, ${ }^{\mathrm{b}}$ Department of Biochemistry, Erasmus

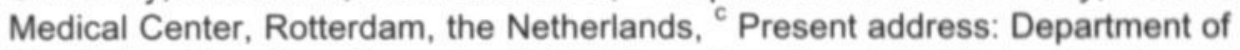
Population Genetics, Genomics \& Bioinformatics, Maastricht University, Maastricht, the Netherlands, ${ }^{d}$ Centre for Nutrition and Health, National Institute for Public Health and the Environment, Bilthoven, the Netherlands

\section{Submitted for publication}




\section{Summary}

Objective To evaluate whether high pulse pressure (PP) is associated with increased prevalence of metabolic or cardiovascular disorders, target organ damage, or abnormal vessel wall properties, and to assess factors contributing to PP. Design A cohort study, Cohort of Diabetes and Atherosclerosis Maastricht, CODAM. An oral glucose tolerance test was done and metabolic variables and carotid artery vessel wall properties were determined. Setting Academic research institute. Participants Subjects $(\mathrm{N}=574)$ were participants from CODAM, aged 42-72 yrs. Interventions None. Main Outcome Measures Carotid wall properties, metabolic parameters, and cardiovascular and metabolic morbidity in quartiles of PP. Results Of the subjects in the highest PP quartile, 39.4\% (adjusted OR 2.1) had diabetes and 51.4\% (adjusted OR 2.8) had metabolic syndrome (Chi-square: $p<0.001$ for both compared to the lowest PP quartile). Subjects in higher PP quartiles showed gradually increased carotid artery wall thickness and stiffness, and had more organ damage of large arteries and the heart. Moreover, the highest PP quartile showed evidence of abnormal fatty acids and glucose metabolism, and insulin resistance. Conclusions Increased PP is not only associated with hypertension and left ventricular hypertrophy, but also with increased arterial stiffness, type 2 diabetes, and the metabolic syndrome. Abnormal fatty acid and glucose metabolism in subjects with high PP can contribute to, or even underlie, these associations. 


\section{Introduction}

The European Society of Hypertension recently published new guidelines to determine overall cardiovascular risk in the hypertensive patient (1). It was recognized that secondary organ involvement, i.e. target organ damage (TOD), could act as a risk factor on its own. Therefore it was recommended that TOD should be added to the common risk factors already used to stratify for cardiovascular risk in subjects with hypertension. Organ damage can be defined at the level of the heart, i.e. left ventricular hypertrophy (LVH), at the level of the vessel wall, i.e. intima media thickness (IMT) or atherosclerotic plaque, and at the level of the kidneys, i.e. increase in serum creatinine concentration and/or presence of microalbuminuria.

Hypertension increases the load on the heart, burdens the wall stress of the arteries, and accelerates cardiovascular degeneration and disease (2). The predictive value of systolic and diastolic blood pressure for death and morbidity of cardiovascular disease (CVD) has been established (3). Blood pressure can be considered as the summation of a steady component, the mean arterial pressure, and a pulsatile component, the pulse pressure (2). Pulse pressure (PP) is the difference between systolic and diastolic blood pressure and is determined by the pattern of left ventricular ejection and arterial wall properties, such as stiffness. Recently, we showed that PP was an independent contributor to intima-media thickness, a surrogate marker of atherosclerosis (M Kruijshoop, CJH van der Kallen, APG Hoeks, EH Lambrichs, EJM Feskens, EE Blaak, TWA de Bruin. Increased arterial stiffness but normal intima-media thickness in recently diagnosed type 2 diabetes mellitus. Manuscript submitted). Furthermore, PP has been recognized as an independent predictor of carotid artery plaque ulceration (4), cardiovascular disease (CVD), and all-cause mortality $(5,6)$. PP may be specifically relevant in older subjects aged $>60$ y $(7,8)$, type 2 diabetes (DM) (9), hyperlipidemia, and subjects with the metabolic syndrome (10), and may represent different and additional information on future risk of cardiovascular disease than diastolic and systolic blood pressure. This concept is supported by recent reports that in humans specific genes are associated with PP but not with systolic or diastolic blood pressures $(11,12)$.

Recently, we initiated a population-based cohort study in the framework of the Cohort study of Diabetes and Atherosclerosis Maastricht (CODAM). The CODAM participants have been well characterized for cardiovascular risk factors, including glucose intolerance $(13,14)$ and carotid artery vessel wall poperties by ultrasound. It was the aim of the present study to cross-sectionally evaluate in this cohort whether subjects with the highest PP had increased co-morbidity, increased prevalence of cardiovascular disorders, increased TOD (1), abnormal carotid artery vessel wall properties, or metabolic abnormalities. 


\section{Subjects and Methods}

\section{Subjects \& measurements}

The Cohort study of Diabetes and Atherosclerosis Maastricht (CODAM) is a prospective, population-based, cohort study in the Netherlands. Based on the results of their baseline examinations, participants of two large ongoing cohorts of the National Institute for Public Health and the Environment in the Maastricht area (Monitoring Project for Cardiovascular Diseases and Monitoring Project on Risk Factors for Chronic Diseases (14)) were invited to participate in a screening for the CODAM study. Inclusion criteria were: age over 40 years and either Body Mass Index (BMI) $>25$ $\mathrm{kg} / \mathrm{m}^{2}$, a positive family history of DM, a history of gestational diabetes, use of antihypertensive medication, a postprandial blood glucose $>6.0 \mathrm{mmol} / \mathrm{L}(108 \mathrm{mg} / \mathrm{dL})$, or glucosuria. Subjects with known DM of long-duration and on insulin treatment were excluded from participation. Subjects who were newly diagnosed with DM by the oral glucose tolerance test (OGTT) at screening have been included. Included subjects were stratified according to glucose tolerance, i.e. as normal glucose tolerant (NGT), impaired glucose tolerant (IGT), or recently diagnosed DM $(13,14)$. Subjects with impaired fasting glucose (IFG) ( $N=25)$ were included in the IGT group. A total of 574 subjects from the CODAM cohort study population were analyzed in the present study.

Subjects visited the Clinical Research Unit twice with a time interval varying between 2 weeks and 10 months. Lipid lowering medication was stopped 10 days before the first visit and all other medication including antihypertensive drugs was stopped the day before the visits. During the first and second visit, blood pressure was measured twice on the right arm in supine position after 5 minutes of rest. The average of both the systolic and diastolic blood pressure (SBP and DBP) measurements of both visits was calculated and PP was defined as average SBP minus average DBP. Mean arterial pressure (MAP) was calculated as DBP + (PP / 3). Hypertension was defined as SBP/DBP $\geq 140 / 90$ (15), or use of antihypertensive medication. In addition, SBP and DBP were measured with a validated automatic oscillometric blood pressure device during the second visit to calculate vessel wall properties (OMRON 705CP, Nieuwegein, the Netherlands). A 12-lead electrocardiogram (ECG) was made with the subject in supine position after 5 minutes rest and coded according to the Minnesota Code System (16). BMI was calculated by dividing weight by height in $\mathrm{kg} / \mathrm{m}^{2}$. Waist circumference (in $\mathrm{cm}$ ) was measured at the level midway between the lateral lower rib margin and the spina iliaca anterior superior with the subject in standing position. Questionnaires were filled out on lifestyle and documented medical history. Prior and current use of medication was registered. At the second visit, a standard Doppler device was used to measure SBP on both arms (a. radialis) and ankles (a. dorsalis pedis) and the Ankle/Brachial Index ( $\mathrm{ABI}$ ) was calculated by the following formula: $\mathrm{ABI}$ $=$ highest SBP a. dorsalis pedis / highest SBP a. radialis.

\section{Subject Definitions}

Glucose tolerance was measured during the first visit by a standard 75-g OGTT with venous plasma glucose measurements and defined according to the $1999 \mathrm{WHO}$ criteria (17). Metabolic syndrome was defined according to the Adult Treatment Panel (ATP) III 
of the National Cholesterol Education Program (NCEP) when 3 or more out of 5 variables (waist circumference, triglycerides, HDL-cholesterol, fasting plasma glucose concentration, and blood pressure) exceeded the predefined threshold (18). Smoking status was considered positive in cases of current or ever smoking. Coronary heart disease (CHD) was considered present in case of documented prior myocardial infarction, bypass surgery, percutaneous transluminal balloon dilation (PTCA), history of coronary angiography, a pacemaker, or any other serious heart condition other than myocardial infarction. Cardiovascular disease (CVD) was considered present when CHD was present, or whether subjects had suffered from stroke, brain haemorrhage, narrowing of blood vessels of the viscerae or legs, prior operation of blood vessels, or documented peripheral artery disease including the viscerae or legs.

\section{Target Organ Damage}

Target Organ Damage (TOD) was defined according to the criteria of the European Society of Hypertension 2003 (1) as follows: TOD-IMT intima-media thickness (IMT) > $0.90 \mathrm{~mm}$, TOD-MA microalbuminuria $>20 \mathrm{mg} / \mathrm{L}$ (19), TOD-LVH LVH either as SokolowLyons index without the presence of a bundle branch block (SV1 + RV5 or $6>38 \mathrm{~mm}$ ) (missing $\mathrm{N}=286$ ) or as Cornell voltage QRS duration product $>2440 \mathrm{~mm}^{*} \mathrm{~ms} \quad(20,21)$ (missing $\mathrm{N}=329$ ), or when the ECG was coded 3.1 or 3.3 according to Minnesota (missing $\mathrm{N}=15$ ) (total missing $\mathrm{N}=12$ ), and TOD-CREAT serum creatinine in men $>115$ $\mu \mathrm{mol} / \mathrm{L}$; in women $>107 \mu \mathrm{mol} / \mathrm{L}$ (11). We extended the criteria for vessel wall damage (IMT) by adding criteria for endothelial dysfunction and peripheral vascular disease (PVD). Endothelial dysfunction, of which plasma soluble intercellular adhesion molecule (sICAM) concentrations is a marker $(22,23)$, was considered present when plasma sICAM concentrations exceeded the 90th percentile, determined in NGT subjects, i.e. $450 \mathrm{ng} / \mathrm{mL}$ (TOD-SICAM). TOD-PVD was considered present when the ABI was below $0.90(24,25)$.

\section{Laboratory Measurements}

Fasting blood samples were drawn to measure fasting insulin concentration, $\mathrm{HbA1c}$, total and high-density lipoprotein (HDL)-cholesterol, triglycerides and free fatty acids (FFA). Glucose was measured by the hexokinase method, as described previously $(13,14)$. Insulin was determined using a two-sided immunoradiometric test by the Endocrinological Laboratory at the University Hospital Vrije Universiteit Amsterdam, the Netherlands, using paired monoclonal antibodies (Medgenix Diagnostics, Fleurus, Belgium). This test is insulin specific and does not show cross reactivity with pro-insulin and split products. Intra- and inter-assay coefficients of variation were $5 \%$ and $6 \%$, respectively. The HOMA-index was calculated as described by Matthews et al. (26). HbA1C was determined by HPLC by the Department of Clinical Chemistry of the Academic Hospital Maastricht, the Netherlands. Total cholesterol, HDL-cholesterol and triglycerides were measured by enzymatic methods (Roche, Mannheim, Germany) by the Department of Clinical Chemistry of the University Hospital Vrije Universiteit Amsterdam (The Netherlands). Low-density lipoprotein (LDL)-cholesterol was calculated according to Friedewald et al. (27). An enzymatic colorimetric method (Wako NEFA C, Richmond, USA) was used for the quantitation of FFA at the Department of 
Clinical Chemistry of the Erasmus Medical Centre (Rotterdam, The Netherlands). Creactive protein (CRP) was measured at the Laboratory of Toxicology, Genetics and Pathology of the National Public Health Institute, Bilthoven (The Netherlands) with a high-sensitive kit (Latex, Roche Diagnostics Nederland BV, Almere, the Netherlands). Plasma creatinine was determined with a Roche kit (Roche Diagnostics Nederland BV, Almere, the Netherlands). SICAM, apolipoprotein B (apoB) and complement factor 3 (C3) were determined in serum by autoanalyzer. A morning urine sample was collected and the concentration of albumin was determined by rate nephelometry (Array Protein System, Beckman, PaloAlto, USA).

\section{Ultrasound procedures}

Carotid IMT was measured with ultrasound in M-mode (Ultramark 4+, ATL, Bothel, Washington, USA) by a linear array transducer of $7.5 \mathrm{MHz}$ positioned perpendicular to the common carotid artery (CCA) in 7 consecutive measurements, as described before (28-30). The median value of the seven measurements was calculated for the left and right side. The average of the left and right median was used as the representative IMT value. When less than five measurements could be done, the measurement was considered missing. When measurements were obtained from one side only, the median value of that side was used in analysis. The inter-observer coefficient of variation was $3.9 \%$, determined in 7 subjects on two occasions. The intra-observer coefficient of variation was $3.7 \%$ with observer 1 , determined in 5 subjects, and $4.0 \%$ with observer 2, determined in 7 subjects. SBP and DBP were measured with a validated automatic oscillometric blood pressure device (OMRON 705CP, Nieuwegein, the Netherlands) on the right arm before the procedure, and after the third and seventh measurement when measuring the right and itet side. The average of all systolic and diastolic measurements during the procedure was calculated. Brachial PP was defined as average SBP minus average DBP and was used only to calculate Young's elastic modulus (YEM).

YEM was assessed with an Ultramark 4+ (Ultramark 4+, ATL, Bothel, Washington, USA) and with the use of an echo wall tracking system at the same position in the CCA as used in IMT measurements. The wall tracking system measures non-invasively the diastolic diameter $\mathrm{d}$ and distension $\Delta \mathrm{d}$, the change in diameter as function of time $(29,30)$. YEM is defined as follows:

YEM $=\mathrm{d} /(\mathrm{IMT} *(\triangle \mathrm{A} / \mathrm{A}) / \mathrm{PP})) \quad(\mathrm{MPa})$,

where $A$ is the diastolic lumen area (calculated by $\left.p^{*}\left(0.5^{*} d\right)^{2}\right), \Delta A$ the change in crosssectional area from diastole to systole (calculated by $\left.p^{*}\left((d+\Delta d)^{2}-d^{2}\right) / 4\right)$, and IMT is the IMT value resulting from the IMT measurement (29). YEM provides information on the mechanical properties of the wall material independent of the geometry (1) and can be considered a marker of arterial stiffness. All measurements were done seven times at both left and right CCA. Measurements were repeated when the diameter showed a standard deviation of more than $1 \%$ and distension showed a standard deviation of more than $10 \%$. The diameters and distensions of the right CCA was different from the left CCA in DM and NGT subjects. We used the average of the left CCA diameter and distension in analyses and calculation of YEM, because of the small number of missing values, and few subjects had the left hand side as the dominant side $(6.3 \%)$. 


\section{Statistical analysis}

SPSS 10.0 for Maclntosh was used for analyses. First, the subjects were classified according to quartiles of PP. Analysis of covariance (General Linear Models procedure) was used to calculate means adjusted for age, gender, BMI and waist circumference, and to calculate $95 \%$ confidence intervals $(\mathrm{Cl})$ of the continuous variables. Tests for trend in mean risk factor values across PP quartiles were calculated from linear regression analysis for continuous variables. For dichotomous variables odds ratios with $95 \% \mathrm{Cl}$ were calculated, adjusted for age, gender, BMI, and waist circumference, based on logistic regression analysis. Plasma triglyceride and urinary albumin concentrations, the HOMA-index, YEM, and CRP showed skewed data distribution and were log-transformed to satisfy conditions of normality. In tables and figures however, their untransformed median values have been used for clarity. To study determinants of PP, univariate regression analyses were carried out with the variables from Table 1 and 2 that were significantly different between the PP quartiles. SBP and DBP were not used as variables for regression analysis because they were used to calculate PP. Likewise, YEM was not used in regression analysis as its calculation includes PP. Multiple backward linear regression analysis was done with the variables that were significant in univariate analysis $(p<0.05)$. Also, smoking, presence of DM or IGT, use of antihypertensive medication, and MAP were entered in the multiple model.

\section{Results}

\section{Pulse pressure quartiles}

The study population consisted of 352 men and 222 women (total $N=574$ ), with mean age $59.1 \pm 7.0 \mathrm{y}$ and mean BMI $28.6 \pm 4.3 \mathrm{~kg} / \mathrm{m}^{2}$. The population was classified into PP quartiles and the characteristics are listed in Tables 1 and 2. After adjustment for age and gender, highly significant differences among PP quartiles were found in BMI, waist circumference, blood pressure parameters including $\mathrm{ABI}$, and vessel wall properties. Each of the carotid wall properties, i.e. carotid IMT, carotid diameter and YEM, showed significant graded increments over PP quartiles and had the highest values in the subjects with the highest PP (Table 1). With regard to metabolic markers, after adjustment for age, gender, BMI and waist circumference, quartiles of PP showed significant associations with $\mathrm{HAA} 1 \mathrm{c}$, fasting and $2 \mathrm{~h}$ post-load glucose, FFA and the HOMA-index (Table 2). There were no differences between the quartiles in total cholesterol, HDL- and LDL-cholesterol, triglycerides, apoB, CRP, C3, creatinine, and sICAM concentrations (Table 2). 
Table 1: Characteristics, blood pressure and vessel wall properties according to quartiles of pulse pressure (PP, $\mathrm{mmHg}$ ), adjusted for age and gender"; Data are given as mean ( $95 \%$ confidence interval).

\begin{tabular}{|c|c|c|c|c|c|}
\hline & $\begin{array}{c}P P 1 \\
N=152 \\
P P \leq 48\end{array}$ & $\begin{array}{c}P P 2 \\
N=135 \\
49 \leq P P \leq 56\end{array}$ & $\begin{array}{c}P P 3 \\
N=145 \\
57 \leq P P \leq 66\end{array}$ & $\begin{array}{c}P P 4 \\
N=142 \\
P P \geq 67\end{array}$ & $\begin{array}{c}p- \\
\text { value** }\end{array}$ \\
\hline Male (\%) & 65.8 & 61.5 & 62.1 & 55.6 & 0.95 \\
\hline Age (years) & $\begin{array}{c}55.2 \\
(54.2-56.2)\end{array}$ & $\begin{array}{c}57.9 \\
(56.8-59.0)\end{array}$ & $\begin{array}{c}60.4 \\
(59.4-61.4)\end{array}$ & $\begin{array}{c}63.1 \\
(62.0-64.1)\end{array}$ & $<0.001$ \\
\hline BMI $\left(\mathrm{kg} / \mathrm{m}^{2}\right)$ & $\begin{array}{c}27.1 \\
(26.4-27.8)\end{array}$ & $\begin{array}{c}28.9 \\
(28.1-29.6)\end{array}$ & $\begin{array}{c}29.0 \\
(28.3-29.7)\end{array}$ & $\begin{array}{c}29.4 \\
(28.7-30.1)\end{array}$ & $<0.001$ \\
\hline Waist circumference $(\mathrm{cm})$ & $\begin{array}{c}95.7 \\
(93.8-97.6)\end{array}$ & $\begin{array}{c}100.5 \\
(98.6-102.4)\end{array}$ & $\begin{array}{c}100.8 \\
(98.9-102.6)\end{array}$ & $\begin{array}{c}101.0 \\
(99.1-103.0)\end{array}$ & $<0.001$ \\
\hline $\begin{array}{l}\text { Systolic blood pressure } \\
(\mathrm{mmHg})\end{array}$ & $\begin{array}{c}121.8 \\
(119.8-123.7)\end{array}$ & $\begin{array}{c}134.8 \\
(132.8-136.7)\end{array}$ & $\begin{array}{c}143.9 \\
(142.0-145.8)\end{array}$ & $\begin{array}{c}163.9 \\
(161.9-165.9)\end{array}$ & $<0.001$ \\
\hline $\begin{array}{l}\text { Diastolic blood pressure } \\
(\mathrm{mmHg})\end{array}$ & $\begin{array}{c}78.3 \\
(76.9-79.8)\end{array}$ & $\begin{array}{c}82.2 \\
(80.7-83.7)\end{array}$ & $\begin{array}{c}83.3 \\
(81.8-84.8)\end{array}$ & $\begin{array}{c}85.2 \\
(83.6-86.7)\end{array}$ & $<0.001$ \\
\hline Pulse pressure $(\mathrm{mmHg})$ & $\begin{array}{c}43.3 \\
(42.3-44.5)\end{array}$ & $\begin{array}{c}52.6 \\
(51.5-53.7)\end{array}$ & $\begin{array}{c}60.5 \\
(59.5-61.6)\end{array}$ & $\begin{array}{c}78.7 \\
(77.6-79.8)\end{array}$ & $<0.001$ \\
\hline $\begin{array}{l}\text { Mean arterial pressure } \\
(\mathrm{mmHg})\end{array}$ & $\begin{array}{c}92.8 \\
(91.3-94.4)\end{array}$ & $\begin{array}{c}99.7 \\
(98.2-101.3)\end{array}$ & $\begin{array}{c}103.5 \\
(102.0-105.0)\end{array}$ & $\begin{array}{c}111.4 \\
(109.8-113.0)\end{array}$ & $<0.001$ \\
\hline $\begin{array}{l}\text { Ankle/Brachial Index a. } \\
\text { dorsalis }\end{array}$ & $\begin{array}{c}1.14 \\
(1.12-1.16)\end{array}$ & $\begin{array}{c}1.13 \\
(1.11-1.15)\end{array}$ & $\begin{array}{c}1.13 \\
(1.11-1.14)\end{array}$ & $\begin{array}{c}1.06 \\
(1.04-1.08)\end{array}$ & $<0.001$ \\
\hline $\begin{array}{l}\text { Urinary albumin } \\
\text { concentration*** (mg/L) }\end{array}$ & 3.3 & 3.6 & 3.4 & 4.3 & $<0.001$ \\
\hline IMT mean (mm) & $\begin{array}{c}0.66 \\
(0.64-0.69)\end{array}$ & $\begin{array}{c}0.69 \\
(0.66-0.71)\end{array}$ & $\begin{array}{c}0.72 \\
(0.69-0.75)\end{array}$ & $\begin{array}{c}0.73 \\
(0.70-0.76)\end{array}$ & $<0.001$ \\
\hline Diameter left CCA (mm) & $\begin{array}{c}7.3 \\
(7.1-7.4)\end{array}$ & $\begin{array}{c}7.5 \\
(7.4-7.7)\end{array}$ & $\begin{array}{c}7.7 \\
(7.5-7.8)\end{array}$ & $\begin{array}{c}8.0 \\
(7.8-8.1)\end{array}$ & $<0.001$ \\
\hline YEM left CCA ** (MPa) & 0.52 & 0.60 & 0.73 & 0.89 & $<0.001$ \\
\hline Resting heart rate (b/min) & $\begin{array}{c}59.9 \\
(58.1-61.7)\end{array}$ & $\begin{array}{c}61.4 \\
(59.6-63.2)\end{array}$ & $\begin{array}{c}63.8 \\
(62.0-65.5)\end{array}$ & $\begin{array}{c}62.5 \\
(60.7-64.3)\end{array}$ & 0.018 \\
\hline Smoking (\%) & 64.9 & 73.3 & 66.9 & 70.4 & 0.63 \\
\hline
\end{tabular}

\footnotetext{
- Standardized to the age and gender distribution of the total study population (except for age which is standardized to the gender distribution only): " square for dichotomous variables; BMI, Body Mass Index; $\cdots$ unadjusted median value shown in table, but pvalue was calculated with log-transformed values, adjusted for age and gender; IMT, intima-media thickness; CCA, common carotid artery: YEM, Young's elastic modulus
} 
Table 2: Metabolic blood parameters according to quartiles of pulse pressure (PP, mmHg), adjusted for age, gender, BMI and waist circumference*; Data are given as mean ( $95 \%$ confidence interval).

\begin{tabular}{|c|c|c|c|c|c|}
\hline & $\begin{array}{c}P P 1 \\
N=152 \\
P P \leq 48\end{array}$ & $\begin{array}{c}P P 2 \\
N=135 \\
49 \leq P P \leq 56\end{array}$ & $\begin{array}{c}\text { PP3 } \\
N=145 \\
57 \leq P P \leq 66\end{array}$ & $\begin{array}{c}P P 4 \\
N=142 \\
P P \geq 67\end{array}$ & $\begin{array}{c}\mathrm{p}- \\
\text { value** }\end{array}$ \\
\hline HbA1c (\%) & $\begin{array}{c}5.9 \\
(5.8-6.0)\end{array}$ & $\begin{array}{c}5.9 \\
(5.7-6.0)\end{array}$ & $\begin{array}{c}6.0 \\
(5.8-6.1)\end{array}$ & $\begin{array}{c}6.3 \\
(6.1-6.4)\end{array}$ & 0.001 \\
\hline Fasting glucose (mmol/L) & $\begin{array}{c}5.8 \\
(5.6-6.1)\end{array}$ & $\begin{array}{c}5.8 \\
(5.5-6.0)\end{array}$ & $\begin{array}{c}6.1 \\
(5.9-6.3)\end{array}$ & $\begin{array}{c}6.7 \\
(6.4-6.9)\end{array}$ & $<0.001$ \\
\hline $\begin{array}{l}\text { Glucose concentration } 2 \mathrm{~h} \\
\text { (mmol/L) }\end{array}$ & $\begin{array}{c}7.1 \\
(6.5-7.7)\end{array}$ & $\begin{array}{c}7.3 \\
(6.8-7.9)\end{array}$ & $\begin{array}{c}8.1 \\
(7.5-8.7)\end{array}$ & $\begin{array}{c}8.6 \\
(7.9-9.2)\end{array}$ & $<0.001$ \\
\hline Free fatty acids (mmol/L) & $\begin{array}{c}0.49 \\
(0.46-0.53)\end{array}$ & $\begin{array}{c}0.51 \\
(0.48-0.54)\end{array}$ & $\begin{array}{c}0.54 \\
(0.51-0.57)\end{array}$ & $\begin{array}{c}0.57 \\
(0.54-0.61)\end{array}$ & 0.001 \\
\hline HOMA-index*.* & 1.70 & 2.28 & 2.09 & 2.61 & 0.028 \\
\hline Total cholesterol $(\mathrm{mmo} / \mathrm{L})$ & $\begin{array}{c}5.08 \\
(4.91-5.25)\end{array}$ & $\begin{array}{c}5.24 \\
(5.08-5.41)\end{array}$ & $\begin{array}{c}5.41 \\
(5.25-5.57)\end{array}$ & $\begin{array}{c}5.14 \\
(4.98-5.32)\end{array}$ & 0.32 \\
\hline HDL-cholesterol (mmol/L) & $\begin{array}{c}1.21 \\
(1.15-1.26)\end{array}$ & $\begin{array}{c}1.14 \\
(1.08-1.19)\end{array}$ & $\begin{array}{c}1.21 \\
(1.16-1.27)\end{array}$ & $\begin{array}{c}1.20 \\
(1.14-1.25)\end{array}$ & 0.75 \\
\hline LDL-cholesterol (mmol/L) & $\begin{array}{c}3.19 \\
(3.04-3.34)\end{array}$ & $\begin{array}{c}3.33 \\
(3.18-3.47)\end{array}$ & $\begin{array}{c}3.48 \\
(3.34-3.63)\end{array}$ & $\begin{array}{c}3.21 \\
(3.06-3.36)\end{array}$ & 0.50 \\
\hline Triglycerides $* *$ (mmol/L) & 1.30 & 1.50 & 1.40 & 1.40 & 0.34 \\
\hline Apolipoprotein B ( $g / L)$ & $\begin{array}{c}1.09 \\
(1.05-1.13)\end{array}$ & $\begin{array}{c}1.13 \\
(1.09-1.18)\end{array}$ & $\begin{array}{c}1.17 \\
(1.13-1.21)\end{array}$ & $\begin{array}{c}1.12 \\
(1.08-1.17)\end{array}$ & 0.19 \\
\hline C-reactive protein $* *$ (mg/L) & 2.08 & 2.86 & 2.38 & 3.13 & 0.11 \\
\hline Complement factor $3(g / L)$ & $\begin{array}{c}1.75 \\
(1.70-1.81)\end{array}$ & $\begin{array}{c}1.83 \\
(1.78-1.88)\end{array}$ & $\begin{array}{c}1.80 \\
(1.75-1.85)\end{array}$ & $\begin{array}{c}1.82 \\
(1.77-1.87)\end{array}$ & 0.17 \\
\hline Creatinine $(\mu \mathrm{mol} / \mathrm{L})$ & $\begin{array}{c}73.7 \\
(71.5-75.9)\end{array}$ & $\begin{array}{c}72.2 \\
(70.1-74.4)\end{array}$ & $\begin{array}{c}70.1 \\
(68.1-72.2)\end{array}$ & $\begin{array}{c}71.7 \\
(69.5-74.0)\end{array}$ & 0.13 \\
\hline $\begin{array}{l}\text { Soluble intercellular } \\
\text { adhesion molecule (ng/mL) }\end{array}$ & $\begin{array}{c}348.1 \\
(332.0-364.2)\end{array}$ & $\begin{array}{c}346.1 \\
(330.0-362.3)\end{array}$ & $\begin{array}{c}364.2 \\
(348.6-379.7)\end{array}$ & $\begin{array}{c}353.2 \\
(336.6-369.8)\end{array}$ & 0.39 \\
\hline
\end{tabular}

- Standardized to the age and gender distribution of the total study population; "* linear regression analysis;

... unadjusted median value shown in table, but p-value was calculated with log-transformed values, adjusted for age and gender; HbA1c, glycosylated haemoglobin; HDL, high-density lipoprotein; LDL, low-density lipoprotein

\section{Target Organ Damage}

In Table 3, the prevalence and odds ratio (OR) with $95 \%$ confidence interval $(\mathrm{Cl})$ of target organ damage (TOD) in the PP quartiles has been listed. After adjustment for age, gender, BMI and waist circumference, PP was significantly associated with a higher TOD-IMT and TOD-PVD. However, TOD-SICAM, target organ damage reflecting endothelial cell activation mostly at the level of the capillaries, was not different between the PP quartiles. TOD-LVH was almost four-and-a-half times as frequent in the highest PP-quartile compared to the lowest PP-quartile. There were no differences between the quartiles in the OR for target organ damage at level of the kidneys, TODCREAT and TOD-MA. 


\section{Clinical Disorders}

Hypertension, CHD and CVD The association with the prevalence of clinical disorders was assessed. As a result of the study design, $99.3 \%$ had hypertension defined as SBP/DBP $\geq 140 / 90$ or antihypertensive medication in the highest PP quartile (Table 3). However, only $54.6 \%$ of the subjects in the highest PP quartile with hypertension used antihypertensive medication. Between quartiles, there were no differences in the use of ACE-inhibitors or lipid medication (data not shown), but nitrates were used more often in the highest PP quartile compared to the lowest quartile $(12.7 \%$ vs. $7.9 \%$, respectively). Although the prevalence of CHD and CVD increased with quartiles of PP (Table 3), the OR's did not reach statistical significance after adjustment for age, gender, BMI and waist circumference.

Type 2 Diabetes From Table 2, it had become apparent that higher fasting glucose and $2 \mathrm{~h}$ post-load glucose plasma concentrations existed in higher PP quartiles. Fifty-six of the 142 subjects $(39.4 \%)$ in the highest PP quartile had DM resulting in an OR of 2.1 (CI 1.1-3.8) for DM in the highest PP quartile, adjusted for age, gender, BMI and waist circumference, compared to the lowest PP quartile $(p<0.05)($ Table 3$)$. The OR for IGT did not reach statistical significance in the highest PP quartile, but was significantly increased in the lower PP quartiles (PP2 and PP3 both $\mathrm{OR}=1.8 ; \mathrm{Cl} 1.0-3.3$ ) suggesting that subjects had progressed from IGT to DM in the highest PP quartile.

Metabolic Syndrome The OR for metabolic syndrome after adjustment for age, gender, $\mathrm{BMI}$ and waist circumference was $2.8(\mathrm{Cl} 1.5-5.3)$ in the highest PP quartile $(51.4 \%)$, which was significantly different from the lowest PP quartile $(26.3 \%)($ Table 3 ). In all PP quartiles the prevalence of the metabolic syndrome was significantly higher than in PP1. Metabolic syndrome and DM together represented $59.8 \%(85 / 142)$ of the subjects in the highest PP quartile. Of the subjects with metabolic syndrome in the highest PP quartile, $60.3 \%(44 / 73)$ also had DM. Furthermore, $8.5 \%(12 / 142)$ of the subjects had DM but no metabolic syndrome.

\section{Effect of exclusion of subjects using antihypertensive medication}

We repeated the analyses described above after exclusion of subjects using antihypertensive medication $(\mathrm{N}=208)$. This resulted in identical conclusions. The only exceptions were that the prevalence rates of CVD and TOD-PVD were no longer significantly different between PP quartiles, compared to the entire study population (Table 3). 
Table 3: Frequency and odds ratios (OR) with confidence interval $(\mathrm{CI})$ in parentheses, adjusted for age, gender, BMI and waist circumference, of Target Organ Damage (TOD) and clinical disorders according to quartiles of pulse pressure (PP, $\mathrm{mmHg}$ ): Data are given in percent.

\begin{tabular}{|c|c|c|c|c|c|c|}
\hline & & $\begin{array}{c}P P 1 \\
N=152 \\
P P \leq 48 \\
\end{array}$ & $\begin{array}{c}P P 2 \\
N=135 \\
49 \leq P P \leq 56\end{array}$ & $\begin{array}{c}P P 3 \\
N=145 \\
57 \leq P P \leq 66\end{array}$ & $\begin{array}{c}P P 4 \\
N=142 \\
P P \geq 67\end{array}$ & $\begin{array}{l}\text { p-value } \\
\text { (Chi- } \\
\text { square) }\end{array}$ \\
\hline \multirow[t]{2}{*}{ TOD-IMT } & (\%) & 4.3 & 9.6 & 15.7 & 16.8 & 0.005 \\
\hline & OR (Cl) & 1 & $2.0(0.7-5.8)$ & $3.3^{*}(1.2-8.8)$ & $3.4^{*}(1.2-9.5)$ & \\
\hline \multirow[t]{2}{*}{ TOD-PVD } & (\%) & 0.7 & 2.3 & 1.4 & 12.1 & $<0.001$ \\
\hline & OR $(\mathrm{Cl})$ & 1 & $2.4(0.2-23.9)$ & $1.2(0.1-14.0)$ & $10.7^{*}(1.3-87.6)$ & \\
\hline \multirow[t]{2}{*}{ TOD-SICAM } & (\%) & 11.2 & 12.7 & 16.6 & 8.5 & 0.19 \\
\hline & OR $(\mathrm{Cl})$ & 1 & $1.0(0.5-2.1)$ & $1.4(0.7-2.8)$ & $0.6(0.3-1.5)$ & \\
\hline \multirow[t]{2}{*}{ TOD-LVH } & (\%) & 12.1 & 11.5 & 28.8 & 35.2 & 0.02 \\
\hline & OR (CI) & 1 & $1.1(0.3-3.3)$ & $3.2^{*}(1.2-8.3)$ & $4.4^{*}(1.5-12.4)$ & \\
\hline \multirow[t]{2}{*}{ TOD-CREAT } & $(\%)$ & 0.7 & 0.5 & 0 & 0.4 & 0.61 \\
\hline & OR (CI) & 1 & $0.5(0.0-9.7)$ & - & $0.4(0.0-6.7)$ & \\
\hline \multirow[t]{2}{*}{ TOD-MA } & (\%) & 8.0 & 6.9 & 10.0 & 15.3 & 0.63 \\
\hline & OR (CI) & 1 & $0.7(0.2-2.0)$ & $0.9(0.3-2.5)$ & $1.8(0.7-4.7)$ & \\
\hline $\begin{array}{l}\text { Hypertension } \\
(\geq 140 / 90)\end{array}$ & $(\%)$ & 29.8 & 46.7 & 75.2 & 99.3 & $<0.001$ \\
\hline Antihypertensive & e $(\%)$ & 24.5 & 31.9 & 35.2 & 54.2 & $<0.001$ \\
\hline \multicolumn{7}{|c|}{ Medication } \\
\hline \multirow[t]{2}{*}{ CHD } & $(\%)$ & 16.2 & 18.7 & 15.4 & 25.5 & 0.12 \\
\hline & OR (CI) & 1 & $1.0(0.5-1.9)$ & $0.7(0.3-1.3)$ & $1.3(0.7-2.5)$ & \\
\hline \multirow[t]{2}{*}{ CVD } & (\%) & 19.7 & 20.3 & 18.7 & 33.3 & 0.011 \\
\hline & OR (CI) & 1 & $0.9(0.5-1.6)$ & $0.7(0.4-1.3)$ & $1.5(0.8-2.7)$ & \\
\hline \multirow[t]{2}{*}{ DM } & (\%) & 17.8 & 17.0 & 28.3 & 39.4 & $<0.001$ \\
\hline & OR (CI) & 1 & $0.7(0.4-1.3)$ & $1.3(0.7-2.4)$ & $2.1^{*}(1.1-3.8)$ & \\
\hline \multirow[t]{2}{*}{ IGT } & $(\%)$ & 15.8 & 25.9 & 26.2 & 22.5 & 0.19 \\
\hline & OR (CI) & 1 & $1.8^{*}(1.0-3.3)$ & $1.8^{*}(1.0-3.3)$ & $1.5(0.8-2.9)$ & \\
\hline \multirow[t]{2}{*}{ MS } & $(\%)$ & 26.3 & 46.7 & 44.1 & 51.4 & $<0.001$ \\
\hline & OR (Cl) & 1 & $2.1^{*}(1.2-3.9)$ & $1.7(0.9-3.1)$ & $2.8^{*}(1.5-5.3)$ & \\
\hline
\end{tabular}

TOD-IMT, target organ damage defined according to intima-media thickness; TOD-PVD, target organ damage defined according to the presence of peripheral vascular disease; TOD-SICAM, target organ damage defined according to the concentration of plasma soluble intercellular adhesion molecule; TOD-LVH, target organ damage defined according to the presence of left ventricular hypertrophy; TOD-CREAT, target organ damage defined according to concentration of plasma creatinine; TOD-MA, target organ damage defined according to the presence of microalbuminuria; $\mathrm{CHD}=$ coronary heart disease; $\mathrm{CVD}=$ cardiovascular disease; $\mathrm{DM}=$ type 2 diabetes mellitus; IGT = impaired glucose tolerance; $\mathrm{MS}$ = metabolic syndrome; * significantly different from PP1

\section{Determinants of pulse pressure}

In univariate regression analysis adjusted for age, gender, BMI and waist circumference, the variables FFA, HbA1c, $2 \mathrm{~h}$ post-load glucose concentration, HOMAindex, CRP, ABI, IMT, diameter of the left CCA, and urinary albumin concentration were significantly associated with PP. In subsequent backward regression analysis, smoking, presence of DM or IGT, use of antihypertensive medication, and MAP were added to these variables. Of these variables, age, gender, FFA, ABI, MAP, IMT, diameter of the left CCA, and waist circumference together predicted $54.6 \%$ of the variance in PP 
(Table 4). MAP predicted the largest part of the variance in PP, i.e. $41.3 \%$. Correlation between PP and MAP was $r=0.643$ and between PP and $A B I r=-0.231$. Addition of fasting insulin concentration or the HOMA-index to the model did not result in a significant contribution to the explained variance.

Table 4: Results of stepwise multiple regression analysis of pulse pressure $(\mathrm{N}=411)$; age, gender, BMI, waist circumference, smoking, presence of type 2 diabetes or impaired glucose tolerance, use of antihypertensive medication, and mean arterial pressure were added to the multivariate model as well as the variables significant in univariate regression analysis.

Pulse Pressure

\begin{tabular}{lccc}
\cline { 2 - 4 } & stand. B & $p$ & $r^{2}$ \\
\hline Age & 0.215 & $<0.001$ & 0.067 \\
Gender (0=male, 1=female) & 0.100 & 0.014 & 0.011 \\
Free fatty acids & 0.101 & 0.004 & 0.011 \\
Ankle/Brachial Index & -0.138 & $<0.001$ & 0.028 \\
Mean arterial pressure & 0.537 & $<0.001$ & 0.413 \\
Intima-media thickness & 0.066 & 0.066 & 0.003 \\
Diameter of the left common carotid artery & 0.151 & $<0.001$ & 0.007 \\
Waist circumference & -0.094 & 0.016 & 0.006 \\
\hline
\end{tabular}

Results are expressed as standardized $B$ and adjusted $r$-square.

\section{Discussion}

The present study showed that increased PP is not only associated with hypertension and LVH, but also with serious clinical metabolic disorders such as DM and the metabolic syndrome, as well as with metabolic abnormalities, specifically increased plasma concentrations of glucose, FFA, and the HOMA-index. In the highest PP quartile ( $\mathrm{PP} \geq 67 \mathrm{mmHg}$ ), $39.4 \%$ of subjects had $\mathrm{DM}$ and more than half of the study population (51.4\%) had metabolic syndrome according to the NCEP definition (18). This was partly explained by a larger degree of insulin resistance, represented by the significantly higher HOMA-index, in the highest PP quartile. A higher PP was also associated with abnormal vessel wall properties that reflect increased arterial stiffness. A small but statistically significant part of the variance in PP was explained by plasma FFA and vessel wall characteristics. The present data suggest a close association between DM, metabolic syndrome and PP. Plasma FFA represent a newly identified determinant of PP and may contribute to the well-known, but unexplained, connection between high blood pressure and DM.

The CODAM study consists of a sample of high-risk subjects from a populationbased cohort and only baseline measurements have been done. However, the CODAM cohort study allows simultaneous cross-sectional comparisons between glucose intolerance categories, the metabolic syndrome, carotid artery vessel wall properties, and other risk factors for CVD including blood pressure parameters. One of the weaknesses in population studies of blood pressure variables is that it is virtually impossible to withhold treatment for hypertension, because at least 2 to 4 weeks without medication seems optimal. In the present study, antihypertensive treatment was not withheld for more than the day prior to measurement. This may have affected the 
average level of blood pressure, but it is generally accepted that PP remains unaltered when hypertension is treated (31). In addition, Mourad et al. (32) showed that the increase in PP with age is independent of the presence of antihypertensive drug treatment. The present finding that carotid artery wall properties like IMT and diameter contribute to PP is a potentially adequate explanation for the observation that the increase in PP with age is independent of use of antihypertensive medication (32), because arterial stiffness also increases with age.

\section{Determinants of pulse pressure}

PP was predicted by carotid vessel wall properties, specifically IMT and carotid diameter. This supported our previous results (M Kruijshoop, CJH van der Kallen, APG Hoeks, EH Lambrichs, EJM Feskens, EE Blaak, TWA de Bruin. Increased arterial stiffness but normal intima-media thickness in recently diagnosed type 2 diabetes mellitus. Manuscript submitted). Furthermore, PP was predicted by age, gender, FFA, and waist circumference, as well as by other blood pressure related variables, such as $\mathrm{ABI}$ and MAP. Most of these variables have been frequently shown to be related to hypertension or PP. Age and gender are known to influence arterial wall properties and therefore influence PP $(2,33)$. Waist circumference is a marker of abdominal obesity which directly leads to hypertension (34). ABI is calculated with systolic blood pressure and is a marker of atherosclerosis present in peripheral vessels $(24,25)$. PP and MAP represent different parts of the same biological variable blood pressure, and are highly associated with each other. However, the small but significant contribution of FFA to PP is a new finding. To our knowledge, only one prospective population study showed a direct association between the development of hypertension and increased concentrations of FFA (35).

\section{Free fatty acids and pulse pressure}

One of the striking findings in the present study is the gradient of the HOMA-index, glucose and FFA over the PP quartiles, which maintained its significance after adjustment for BMI, waist circumference, age and gender. An impaired insulin-induced suppression of plasma FFA has been reported in essential hypertension (36) as well as in insulin resistant states (37). Indeed, a prospective association between plasma FFA and the development of hypertension has been found (35). In the present study, an increasing gradient in arterial stiffness was observed over the PP quartiles concomitant with an increase in plasma FFA levels, and this was confirmed by the significant contribution of FFA to PP in multivariate analysis. However, it is not clear how the small, but statistically significant effect of FFA should be interpreted, i.e. as a direct effect of FFA, or as a result of indirect effects on gene transcription and expression. It should be realized that plasma FFA levels are under tight control. Indirect metabolic effects of FFA include inhibition of phosphatidyl 3-kinase (PI3K) (38) and activation of transcription factors like PPAR-gamma (39). Moreover, increased plasma FFA can result in retention of lipoproteins and albumin-bound FFA to the proteoglycan matrix $(40,41)$ with a direct effect on stiffness. Taken all evidence into account, plasma FFA can represent a newly uncovered factor that contributes indirectly to increments in arterial stiffness and PP. 


\section{Mechanisms of comorbidity with high pulse pressure}

Subjects in the highest quartile of PP showed a significantly greater proportion of clinical disorders, including DM. In addition, $51.4 \%$ of subjects in the highest PP quartile fulfilled the criteria of the NCEP definition of metabolic syndrome, compared to $26.3 \%$ in the lowest quartile of PP. The observed frequency of metabolic syndrome in the lowest PP quartile is somewhat higher than the true population frequency in the Netherlands which may be caused by a relative over-sampling in CODAM of subjects at risk of DM. However, the prevalence found $(26.3 \%)$ is approximately the same as the estimated population frequency of metabolic syndrome in the US of $25 \%(42)$. Subjects with metabolic syndrome are at a high risk of future DM (18). Lipid profiles however (total cholesterol, triglycerides, HDL-cholesterol and LDL-cholesterol) were identical in the 4 quartiles, which means that plasma lipid proteins had similar potential effects on the progression to metabolic syndrome or DM in all quartiles. The present results suggest that individuals in the highest PP quartile were subjected to specific other factors associated with the progression to metabolic syndrome and DM. Such factors are likely to be higher BMI, waist circumference, and blood pressure, but also the gradient of FFA and the HOMA-index. Several published arguments exist to explain why plasma FFA can contribute to abnormalities in the highest PP quartile, and can be involved in metabolic processes that underlie the progression from IGT to DM as well $(35,43-45)$. Taken all evidence together, FFA represent a pleiotropic metabolic factor which may be implicated in increments in PP and in progression from IGT to DM by multiple mechanisms. However, plasma FFA levels may not be the correct representation of these mechanisms, because FFA have intercellular effects.

\section{Conclusions}

The present data advance our understanding of high PP and document the relationship of high PP ( $\geq 67$ ) with DM, metabolic syndrome, and metabolic abnormalities including fatty acid and glucose metabolism. Increased PP is associated with serious clinical metabolic disorders and not only with hypertension, LVH, increased MAP, and increased carotid artery stiffness. In the highest population quartile of PP ( $\geq 67)$, more than half $(59.8 \%)$ of the subjects showed either metabolic syndrome or DM. Plasma FFA were newly identified as a small, but independent, metabolic determinant of PP in multivariate analysis, in addition to age, carotid IMT and carotid diameter. Moderately elevated plasma FFA in subjects with high PP can reflect underlying metabolic abnormalities involved in the well-known associations between high blood pressure, diabetes and the metabolic syndrome.

\section{Acknowledgments}

We thank Jos Stegen and the employees of the laboratories in Amsterdam, Rotterdam and Bilthoven for their expert technical assistance.

\section{References}

1. European Society of Hypertension-European Society of Cardiology guidelines for the management of arterial hypertension. J Hypertens 2003; 21: 1011-1053 
2. Nichols WW, O'Rourke M. McDonald's Blood Flow in Arteries: Theoretical, Experimental and Clinical Principles. 4th ed. London: Edward Amold; 1998

3. Prospective Studies Collaboration. Age-specific relevance of usual blood pressure to vascular mortality: a meta-analysis of individual data for one million adults in 61 prospective studies. Lancet 2002; 360: 1903-1913

4. Lovett JK, Howard SC, Rothwell PM. Pulse pressure is independently associated with carotid plaque ulceration. J Hypertens 2003; 21: 1669-1676

5. Domanski M, Norman J, Wolz M, Mitchell G, Pfeffer M. Cardiovascular risk assessment using pulse pressure in the first National Health and Nutrition Examination Survey (NHANES I). Hypertension 2001; 38: 793-797

6. Benetos A, Safar M, Rudnichi A, et al. Pulse pressure: a predictor of long-term cardiovascular mortality in a French male population. Hypertension 1997; 30: 1410-1415

7. Franklin SS, Larson MG, Kahn SA, et al. Does the relation of blood pressure to coronary heart disease risk change with aging? The Framingham Heart Study. Circulation 2001; 103: 1245-1249

8. Blacher J, Staessen JA, Girerd X, et al. Pulse pressure not mean pressure determines cardiovascular risk in older hypertensive patients. Arch Intern Med 2000; 160: 1085-1089

9. Schram MT, Kostense PJ, van Dijk RAJM, et al. Diabetes, pulse pressure and cardiovascular mortality: the Hoorn study. J Hypertension 2002; 20: 1743-1751

10. Sattar N, Gaw A, Scherbakova O, et al. Metabolic syndrome with and without Creactive protein as a predictor of coronary heart disease and diabetes in the West of Scotland Coronary Prevention Study. Circulation 2003; 108: 414-419

11. Medley L, Cole TJ, Gatzka CD, Wang WYS, Dart AM, Kingwell BA. Fibrillin-1 genotype is associated with aortic stiffness and disease severity in patients with coronary artery disease. Circulation 2002; 105: 810-815

12. Camp NJ. Hopkins PN, Hasstedt SJ, et al. Genome-wide multipoint parametric linkage analysis of pulse pressure in large, extended Utah pedigrees. Hypertension 2003; 42: 322-328

13. Kruijshoop M, Feskens EJM, Blaak EE, de Bruin TWA. Validation of capillary glucose measurements to detect glucose intolerance or type 2 diabetes in the general population. Clin Chim Acta 2004; $341: 33-40$

14. Mensink M, Corpeleijn E, Feskens EJM, et al. Study on lifestyle-intervention and impaired glucose tolerance Maastricht (SLIM): design and screening results. Diabetes Res Clin Pract 2003; 61: 49-58

15. The sixth report of the Joint National Committee on prevention, detection, evaluation, and treatment of high blood pressure. Arch Intern Med 1997; 157: 2413-2446

16. Rose GA, Blackburn H. Cardiovascular survey methods. World Health Organization Monograph Series No. 56 1968; World Health Organization, Geneva

17. World Health Organization: Definition, diagnosis and classification of diabetes mellitus and its complications. Report of a WHO Consultation. Part 1: Diagnosis and classification of diabetes mellitus. WHO Technical Report Series 1999; 1-59

18. Expert Panel on Detection, Evaluation, and Treatment of High Blood Cholesterol in Adults. Executive Summary of The Third Report of The National Cholesterol Education Program (NCEP) Expert Panel on Detection, Evaluation, and Treatment of High Blood Cholesterol In Adults (Adult Treatment Panel III). JAMA 2001; 285: 2486-2497

19. Marshall SM. Screening for microalbuminuria: Which measurement? Diabet Med 1991; 8: 706-711

20. Sokolow M, Lyon TO. The ventricular complex in left ventricular hypertrophy as obtained by unipolar precordial and link leads. Am Heart J 1949; 37: 161-186

21. Molloy TJ, Okin PM, Devereux RB, Kligfield P. Electrocardiographic detection of left ventricular hypertrophy by the simple QRS voltage-duration product. J Am Coll Cardiol 1992; 20: 1180-1186

22. Caballero $A E$, Arora $S$, Saouaf $R$, et al. Microvascular and macrovascular reactivity is reduced in subjects at risk for type 2 diabetes. Diabetes 1999; 48: 1856-1862 
23. Hwang S-J, Ballantyne CM, Sharrett AR, et al. Circulating adhesion molecules VCAM-1, ICAM-1 and $\mathrm{E}$-selectin in carotid atherosclerosis and incident coronary heart disease cases. The Atherosclerosis Risk in Communities (ARIC) Study. Circulation 1997; 96: 4219-4225

24. Schroll M, Munck O. Estimation of peripheral arteriosclerotic disease by ankle blood pressure measurements in a population study of 60-year-old men and women. J Chron Dis 1981; 34: 261 269

25. Fowkes FGR, Housley E, Cawood EHH, Macintyre CCA, Ruckley CV, Prescott RJ. Edinburgh Artery Study: Prevalence of asymptomatic and symptomatic peripheral arterial disease in the general population. Int J Epidemiol 1991; 20: 384-392

26. Matthews DR, Hosker JP, Rudenski AS, Naylor BA, Treacher DF, Turner RC. Homeostasis model assessment: insulin resistance and B-cell function from fasting plasma glucose and insulin concentrations in man. Diabetologia 1985; 28:412-419

27. Friedewald WT, Levy R, Fredrickson DS. Estimation of concentration of LDL cholesterol without the use of preparative ultracentrif uge. Clin Chem 1972; 18; 499

28. Keulen ET, Kruijshoop M, Schaper NC, Hoeks AP, de Bruin TW. Increased intima-media thickness in familial combined hyperlipidemia associated with apolipoprotein B. Arterioscler Thromb Vasc Biol 2002; 22: 283-288

29. Brands PJ, Hoeks AP, Willigers J, Willekes C, Reneman RS. An integrated system for the noninvasive assessment of vessel wall and hemodynamic properties of large arteries by means of ultrasound. Eur J Ultrasound 1999; 9: 257-266

30. Van Bortel LM, Duprez D, Starmans-Kool MJ, et al. Clinical applications of arterial stiffness, Task Force III: recommendations for user procedures. Am J Hypertens 2002; 15: 445-452

31. Van Bortel LMAB, Struijker-Boudier HAJ, Safar ME. Pulse pressure, arterial stiffness, and drug treatment of hypertension. Hypertension 2001; 38: 914-921

32. Mourad J, Blacher J, Blin P. Warzocha U. Conventional antihypertensive drug therapy does not prevent the increase of pulse pressure with age. Hypertension 2001; 38: 958-962

33. Smulyan H, Asmar RG, Rudnicki A, London GM, Safar ME. Comparative effects of aging in men and women on the properties of the arterial tree. J Am Coll Cardiol 2001; 37: 1374-1380

34. Montani J-P, Antic V, Yang Z, Dulloo A. Pathways from obesity to hypertension: from the perspective of a vicious triangle. Int J Obes 2002; 26: S28-S38

35. Fagot-Campagna A, Balkau B, Simon D, et al. High free fatty acid concentration: an independent risk factor for hypertension in the Paris Prospective Study. Int J Epidemiol 1998; 27 808-813

36. Ligtenberg JJ, van Tol A, van Haeften TW, Sluiter WJ, Reitsma WD, Dullaart RP. Impaired suppression of plasma free fatty acids and triglycerides by acute hyperglycaemia-induced hyperinsulinaemia and alterations in high density lipoproteins in essential hypertension. J Intern Med 1996; 240: 233-242

37. Van der Kallen CJH, Voors-Pette C, Bouwman FG, et al. Evidence of insulin resistant lipid metabolism in adipose tissue in familial combined hyperlipidemia, but not type 2 diabetes mellitus. Atherosclerosis 2002; 164: 337-346

38. Baron AD. Insulin resistance and vascular function. J Diabetes Complications 2002; 16: 92-102

39. Stefan N, Fritsche A, Häring H, Stumvoll M. Effect of experimental elevation of free fatty acids on insulin secretion and insulin sensitivity in healthy carriers of the Pro12Ala polymorphismof the peroxisome proliferator-activated receptor- $\gamma 2$ gene. Diabetes 2001; 50: 1143-1148

40. Camejo G, Olsson U. Hurt-Camejo E, Baharamian N, Bondjers G. The extracellular matrix on atherogenesis and diabetes -associated vascular disease. Atherosclerosis Suppl 2002; 3: 3-9

41. Claire M, Jacotot $B$, Robert L. Characterization of lipids associated with macromolecules of the intercellular matrix of human aorta. Connect Tissue Res 1976; 4: 61-71

42. Ford ES, Giles WH, Dietz WH. Prevalence of the metabolic syndrome among US adults. Findings from the third national health and nutrition examination survey. JAMA 2002; 287: 356-359

43. Roden M, Price TB, Perseghin G, et al. Mechanism of free fatty acid-induced insulin resistance in humans. J Clin Invest 1996; 97: 2859-2865 
44. Mensink M, Blaak EE, Baak MA van, Wagenmakers AJ, Saris WH. Plasma free fatty acid uptake and oxidation are already diminished in subjects at high risk for developing type 2 diabetes.

Diabetes 2001; 50: 2548-2554

45. Mootha VK, Lindgren CM, Eriksson KF, et al. PGC-1 $\alpha$-responsive genes involved in oxidative phosphorylation are coordinately downregulated in human diabetes. Nat Genet 2003; 34: 267-273 
CHAPTER 7

General discussion 


\section{1: Diagnosis of type 2 diabetes}

7.2: Type 2 diabetes and arterial wall properties

7.2.1: Intima-media thickness

7.2.2: Arterial stiffness

7.3: Type 2 diabetes and cardiovascular disease

7.4: Progression to type 2 diabetes: influence of free fatty acids and blood pressure

7.5: Implications of the CODAM study

7.6: Technical considerations

7.6.1: Diagnosis and treatment of type 2 diabetes

7.6.2: Methods to measure arterial stiffness

7.6.3: Blood pressure measurements

\section{6: Conclusions}


Type 2 diabetes mellitus represents a metabolic disorder of multiple aetiology, which is characterized by chronic hyperglycemia caused by impaired insulin action and secretion (1). It can cause long-term damage, dysfunction and failure of various organs. Patients with type 2 diabetes are at increased risk of developing coronary heart disease, cerebrovascular disease and peripheral vascular disease, and approximately 60 to $70 \%$ of the patients with type 2 diabetes die from myocardial infarction and stroke (2). The main theory to explain the increased risk of cardiovascular disease (CVD) in type 2 diabetes holds that the increase in risk is caused by an increased rate of atherosclerosis, which principally occurs in large and medium-sized elastic and muscular arteries. The prevalence of type 2 diabetes is expected to increase from its present level of 150 million to 300 million by 2025 (3). Furthermore, approximately 20 to $25 \%$ of the subjects in Western populations have impaired glucose tolerance (IGT)(1) or the metabolic syndrome $(1,4)$, and both are considered to represent a pre-diabetic state. More information is needed on the relationship between different levels of blood glucose concentrations, disturbances in blood glucose concentrations, or the metabolic syndrome and the development of atherosclerosis. Therefore, a prospective, population based cohort study was created to study the effects of glucose tolerance on atherosclerosis, the Cohort study Diabetes and Atherosclerosis Maastricht (CODAM). The first results of this study have been described in this thesis.

\section{1: Diagnosis of type 2 diabetes}

Subjects of the CODAM study were stratified according to glucose tolerance after a 75 $\mathrm{g}$ oral glucose tolerance test (OGTT) with venous blood glucose sampling. This is considered the gold standard to diagnose (or exclude) type 2 diabetes mellitus and is recommended in epidemiological studies by the WHO (1). However, an OGTT with venous sampling may not be feasible in large epidemiological studies. In 1999, the WHO has adjusted the diagnostic criteria for type 2 diabetes mellitus, impaired and normal glucose tolerance (IGT and NGT) in venous plasma and whole blood, as well as in capillary plasma and whole blood (1). Capillary glucose measurements may provide an alternative because they are easier, less expensive and less invasive to obtain. Furthermore, it was shown that modern hand-held glucose measuring devices have excellent technical characteristics and yield similar results as reference laboratory methods $(5,6)$. In the Diabetes Prevention Program study (DPP) (7), the ratio of screened and detected subjects with IGT was 1 out of 43.9 subjects when the following procedure was followed: 1) an initial screening including a capillary or venous glucose determination (fasting or non-fasting); 2) administration of an OGTT to diagnose IGT according to modified criteria of the American Diabetes Association (8). Instead, the inclusion protocol of the CODAM study used high risk criteria to invite subjects for screening with a capillary 75-g OGTT (Chapter 2, Table 1) and resulted in a more favourable ratio of screened and detected subjects with IGT, i.e. 1 out of every 7.1 subjects (Chapter 3 ). Therefore, use of capillary glucose measurements in combination with specific inclusion criteria can result in cost-effective inclusion schemes for future diabetes prevention programs.

The screening for the CODAM study was done with a Glucometer Elite (Bayer), a commercially available glucose meter, which measures capillary blood glucose 
(Chapter 3). Inclusion in the CODAM study was done by venous blood glucose measurements, and we compared capillary measurements done with the Glucometer Elite $\AA$ with venous blood glucose measurements drawn through a canula and analysed in a laboratory with standard enzymatic assays in a subset of the cohort (Chapter 4). We showed that the consistency in classification according to the 1999 WHO criteria (1) between capillary and venous glucose measurements was $78 \%$ ( $k=0.65, p<0.001)$. Sensitivity and specificity to diagnose type 2 diabetes by capillary glucose measurements were $84 \%$ and $98 \%$, respectively. Among the subjects with diabetes, 17 out of 111 subjects $(15.3 \%)$ were classified as IGT by capillary glucose criteria compared with classification by venous glucose criteria and thus remained glucose intolerant. Only 1 subject was classified as normal glucose tolerant (NGT). In subjects with NGT, 12 out of 143 subjects $(8.4 \%)$ were classified as IGT and none as having type 2 diabetes. However, in subjects with IGT, 48 out of 96 subjects $(50.0 \%)$ were differently categorised of which 44 were diagnosed as NGT according to capillary levels. Therefore, we concluded that capillary glucose measurements are sufficiently reliable and precise to detect subjects with NGT and type 2 diabetes when using

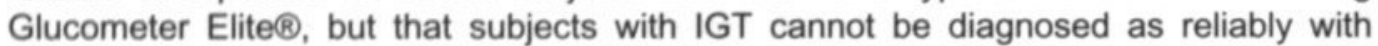
capillary glucose measurements.

The finding that IGT cannot be diagnosed as reliably with capillary glucose measurements compared to NGT and type 2 diabetes may partly be an artefact caused by the narrow range of defined cut-off points for 2-hour glucose concentrations in IGT. Small deviations (i.e. $0.2 \mathrm{mmol} / \mathrm{L}$ ) can result in large numbers of misclassification. In addition, the background of IGT represents a diverse set of metabolic abnormalities including insulin secretion defects and insulin resistance, and to precisely define IGT status remains a topic of continued discussion (9-12). The upper cut-off value has been firmly established as the point between risk of microvascular complications, such as diabetic retinopathy, and minimal risk of complications. On the other hand, the lower cut-off value for IGT is based on consensus rather than on evidence. More research is needed to see whether modification of the lower value is worthwhile in identifying subjects at risk of type 2 diabetes and CVD.

\section{2: Type 2 diabetes and arterial wall properties}

The increased risk of CVD in type 2 diabetes is thought to be caused by an increased rate of atherosclerosis. The atherosclerotic process in itself is slow and relatively benign. Therefore, it can take many years until the first clinical manifestations present itself and result in cardiovascular events (13). Clinical manifestations of CVD however, are 2 to 4 times more frequent in diabetes than in the control population. As discussed in Chapter 1, clustering of multiple risk factors for atherosclerosis, inflammation and/or a combination of these processes as well as presently unknown factors, are thought to be crucial in the development of CVD events. Furthermore, lipid retention in the arterial wall is considered a very important part of the atherosclerotic process. Lipid retention was shown to be accelerated by advanced glycation end-products (AGEs) which can trap soluble plasma lipoproteins in the arterial wall (14). The specific interaction of LDL with the negatively charged glycosaminoglycans of proteoglycans in the arterial intima increase the susceptibility of LDL to oxidation processes (15). Also, high concentrations 
of free fatty acids (FFA) are often found in plasma of subjects with type 2 diabetes (16) and FFA can increase the affinity of the matrix for LDL to the proteoglycan matrix $(15,17)$.

The slow and silent progression of atherosclerosis in humans has resulted in a search for surrogate markers to study determinants of atherosclerosis and the influence of disease modifiers on atherosclerosis progression. Two of these surrogate markers are intima-media thickness (IMT) and arterial stiffness. IMT measurements include among others structural changes involving hyperplasia of arterial smooth muscle cells (18), but are also subject to remodelling. Arterial stiffness is considered to be a measure of early functional loss of elasticity and compliance within the vascular system (19). An increase in carotid IMT was shown to be associated with an increase in cardiovascular events by several prospective cohort studies (13) and in general reflect increased vascular aging. Furthermore, IMT has been validated as a marker of vascular damage and of future cardiovascular risk (20). Arterial stiffness can be represented by different parameters, i.e. the distensibility coefficient, the compliance coefficient, or Young's elastic modulus (YEM) (21). Reproducibility of these parameters is adequately sufficient to be used in epidemiological studies $(22,23)$, and it has been shown that both distensibility and YEM are strong independent predictors of future CVD $(24,25)$. In the present study, we used IMT and YEM as validated surrogate markers of atherosclerosis.

In the CODAM study, ultrasound measurements were done at a single point in the common carotid artery. This enabled the calculation of both surrogate markers of the atherosclerotis process, i.e. IMT and arterial stiffness at the same arterial site, namely between $10-20 \mathrm{~mm}$ of the bifurcation of the common carotid artery. Our protocol to accept ultrasound measurements was very strict to reduce the chance of including erroneous results in analysis which might have affected the outcomes. Reasons for missing data on ultrasound measurements, or subjects, in the CODAM study were cardiac arrhythmia (extrasystoles, atrial fibrillation) (26), longitudinal or oscillating movements of the carotid artery which may indicate enhanced atherosclerosis (27), (neck) obesity, or logistic problems. In general, subjects who did not complete the ultrasound measurements were more obese than subjects who successfully underwent all measurements (Chapter 2). It can be speculated that complete measurements of the missing subjects would, most likely, have strengthened our present findings, especially the data on arterial stiffness, because obesity was a predictor of arterial stiffness in the present study (see section 7.2.2). In future studies, missing data may be prevented by improving ultrasound protocols in such manner that movements of the carotid artery or cardiac arrhythmia has no influence on the performance and outcome of the measurements. See also section 7.6.2 and 7.6.3.

\subsection{1: Intima-media thickness}

Intima-media thickness (IMT) has been reported to be increased in subjects with type 2 diabetes (28-37). However, most of these studies recruited diabetes patients fom clinics. It is likely that these patients had diabetes of longer duration than subjects detected by screening or at least had a clinical manifestation that warranted diagnostic procedures and/or treatment in the clinic. A longer duration may well have resulted in the increased IMT reported in literature (28-37). In contrast, we found similar IMT 
among subjects with recently diagnosed type 2 diabetes, IGT and NGT (Chapter 5). Recently, Hunt et al. also reported that common carotid artery IMT was similar in prediabetic and non-diabetic subjects (38). Moreover, we could establish that carotid diameter and pulse pressure, but not the pre-diabetic state or type 2 diabetes itself, were independent predictors of carotid IMT.

With increasing age, arterial remodelling can result in increased IMT as a compensatory response to counteract increased arterial wall stress caused by an increased luminal diameter (Law of Laplace). Due to the fact that ultrasound protocols were similar in the Hoorn study (39) and the present CODAM study, we could estimate the yearly increment in IMT, albeit in a crude manner (Chapter 5). From the published data of the Hoorn study, it appeared that subjects with diabetes aged 70 years or older had higher IMT than NGT subjects (39). Our estimation suggests that, between 59 and 69 years of age, an acceleration occurs in IMT thickening in subjects with recently diagnosed type 2 diabetes compared to subjects with NGT. This supports the finding in the literature that IMT can be increased in longstanding type 2 diabetes (28-37), as well as the concept that arterial wall properties, measured as IMT, deteriorate more rapidly during hyperglycemia and with clustering of risk factors, such as obesity and hypertension, than with increasing age alone. Furthermore, the estimation also suggests that a substantial part of the increase in IMT occurs during the diabetic state and, therefore, may be prevented. In the interpretation of these data, it should be recognized that IMT is not a static measure, but is subject to remodelling.

\subsection{2: Arterial stiffness}

Arterial stiffness can be described by the distensibility and compliance coefficients, or Young's elastic modulus (YEM), as described before. More specifically, the distensibility and compliance coefficients indicate arterial adaptation, whereas YEM represents arterial remodelling $(18,19)$. In the present study, the distensibility coefficient and YEM were predicted by the same variables, i.e. age, gender, hypertension, total cholesterol, and sagittal diameter. These variables explained $38.4 \%$ of the variance in the distensibility coefficient and $27.8 \%$ of the variance in YEM. As the contributing variables were identical and because the distensibility coefficient is used in the calculation of YEM, we focused on YEM in Chapter 5. YEM was significantly higher in subjects with type 2 diabetes compared to subjects with IGT or NGT. In Chapter 2, we showed that the compliance coefficient was similar among subjects with type 2 diabetes, IGT and NGT, but that the distensibility coefficient was significantly different between these three groups. Therefore, we conclude that arterial stiffness, and more specifically arterial adaptation and remodelling, was already significantly increased in recently diagnosed type 2 diabetes. This may indicate that factors other than hyperglycemia are responsible for this early increase, and that early prevention or reduction of arterial stiffness may be a realistic future aim in diabetes. It is not fully clear yet why arterial stiffness is aready higher in recently diagnosed type 2 diabetes. Clustering of several factors, including hypertension, obesity and increased free fatty acids, against the background of hyperglycemia, may play an important role.

We furthermore estimate the increase in YEM to be accelerated in subjects with diabetes compared to NGT subjects by data from the Hoorn study (39) and the present study (Chapter 5). This estimation could indicate that, once type 2 diabetes has 
developed, hyperglycemia can have an effect additive to the effect of age and hypertension on increasing arterial stiffness, probably by the effect of AGEs that cause structural changes in the vessel wall (15).

\section{3: Type 2 diabetes and cardiovascular disease (CVD)}

We already mentioned that the risk of CVD is increased two to fourfold in subjects with type 2 diabetes compared to non-diabetic subjects, and over $50 \%$ of all patients with type 2 diabetes die from coronary heart disease $(40)$. When patients with diabetes develop CVD, they sustain a worse prognosis for survival than do CVD patients without diabetes (41). Both type 2 diabetes and CVD have common risk factors such as age, obesity, hypertension and dyslipidemia. Clustering of these risk factors are often seen in type 2 diabetes, but usually precede the onset of diabetes by several years.

In Chapter 2, we showed that hyperglycemia is associated with risk factors for CVD, such as elevated plasma cholesterol, triglycerides, free fatty acids and insulin concentrations, as well as with increased body fatness and increased abdominal fat. Furthermore, subjects with type 2 diabetes had significantly more hypertension, peripheral vascular disease, and endothelial and renal dysfunction. Moreover, carotid arterial stiffness, a surrogate marker of atherosclerosis, was already increased in subjects with recently diagnosed type 2 diabetes. Self-reported CVD and coronary heart disease were somewhat higher in subjects with type 2 diabetes than in subjects with NGT, $25.7 \%$ versus $20.1 \%$ and $20.0 \%$ versus $16.9 \%$ respectively, but these differences were not statistically significant. This may be due to the fact that these subjects were diagnosed early in the disease process. We conclude therefore, that subjects in the CODAM study with recently diagnosed type 2 diabetes are at increased risk of CVD and already have some pre-clinical vascular damage, although not sufficiently to have caused significantly more cardiovascular events.

\section{4: Progression to type 2 diabetes: influence of free fatty acids and blood pressure}

Several factors are involved in the progression from IGT to type 2 diabetes, which also increase the risk of CVD, i.e. obesity, hypertension, dyslipidemia, and hyperglycemia. In Chapter 5, we showed that hypertension was one of the determinants of arterial stiffness and that pulse pressure (PP), the difference between systolic and diastolic blood pressure, was an important determinant of IMT. Therefore, we divided the subjects in quartiles of PP to analyse whether subjects with the highest PP had increased clinical disorders, such as type 2 diabetes mellitus and the metabolic syndrome (Chapter 6). We observed that cohort participants in the highest quartile of PP, i.e. $\geq 67 \mathrm{mmHg}$, had a significantly greater proportion of type 2 diabetes and metabolic syndrome. This may be partly explained by a larger degree of insulin resistance, represented by the significantly higher HOMA-index, in the highest PP quartile. As classical lipid profiles were similar in the quartiles, we suggested that individuals in the highest PP quartile were subjected to other specific factors that are associated with progression to type 2 diabetes. These factors may be a higher BMI, 
waist circumference, and hypertension, but also higher free fatty acids (FFA). We found that fasting FFA plasma concentration increased over quartiles of PP, and was a small, but significant predictor of PP in the present CODAM study (Chapter 6). Plasma FFA concentration is tightly regulated and whether the effect of FFA on PP is direct or indirect, for instance via effects on gene expression, remains to be determined.

Several arguments have been published to explain why plasma FFA may be involved in metabolic processes that underlie the progression from IGT to type 2 diabetes. Many factors may contribute to this progression, including a relative impairment of uptake and oxidation of FFA which can result in an elevated plasma FFA concentration (42). Elevated plasma FFA can cause the development of insulin resistance (43) which may result in an increased supply of FFA to the liver and increased gluconeogenesis, a hallmark of diabetes. Therefore, FFA are a serious candidate implicated in the progression from impaired glucose tolerance to type 2 diabetes. Furthermore, our results were in agreement with the Paris Prospective Study which showed that FFA were associated with the development of hypertension (44). Taken all evidence together, FFA may represent a pleiotropic metabolic factor that may be implicated in increments in PP and in progression from IGT to type 2 diabetes.

\section{5: Implications of the CODAM study}

In Chapter 2, we showed that self-reported CVD and coronary heart disease were not significantly different between subjects with recently diagnosed type 2 diabetes, IGT or NGT in the CODAM study. However, once type 2 diabetes is present, we estimate that IMT and arterial stiffness, two surrogate markers of atherosclerosis, may increase more over time than would be expected compared to normal subjects (Chapter 5). This has also been shown in several studies $(28-37,39)$. One possibility is that, when plasma glucose exceeds the diagnostic threshold of diabetes, the effect of risk factors for CVD increase to such extent that the aging process of the vessels of subjects with diabetes seems to be accelerated compared to normal subjects, and CVD events occur earlier and more frequently than would be expected at that age. We schematically show this hypothesis in Figure 1, in which we outlined a possible relationship between age and CVD events for different situations.

With increasing age, the risk on CVD is increasing. Once it increases above a hypothetical threshold, CVD events start to occur. Four different situations have been outlined. Line $\mathrm{P}$ represents individuals who are protected against CVD events, either genetically or by lifestyle, or both. Line $\mathrm{N}$ represents the normal situation that occurs in most individuals. Line $S$ represents individuals who are susceptible for CVD events

such as subjects with familial combined hyperlipidemia $(F C H)$ or familial hypercholesterolemia, who are at risk of myocardial infarction before the age of 60 (45). Line DM represents subjects who are hyperglycaemic and develop type 2 diabetes. These subjects follow the normal line $\mathrm{N}$ until diabetes is present at point X1 or X2. It is even possible that subjects that develop type 2 diabetes in the future are at a higher risk compared to subjects who don't develop type 2 diabetes, as clustering of risk factors precedes the development of type 2 diabetes in these subjects. In this case, the line should be between line $\mathrm{N}$ and line $\mathrm{S}$. After point $\mathrm{X} 1$ or $\mathrm{X} 2$, the point at which diabetes is presenting, the risk on CVD increases faster, probably exponentially, which 
results in an earlier occurrence of a CVD event than when type 2 diabetes is not present. In epidemiological studies, a higher risk of CVD events in type 2 diabetes has been shown $(2,8)$. Recently, Scuteri et al. published results from the Baltimore Longitudinal Study that showed that components of the metabolic syndrome interact synergistically on vascular thickness and stiffness which results in amplified vascular aging (46). These results are in agreement with our hypothesis of increased vascular aging against a background of hyperglycemia. Whether this increased risk is caused by clustering of different risk factors, increased oxidative stress or inflammation of the arterial wall remains to be determined by future research.

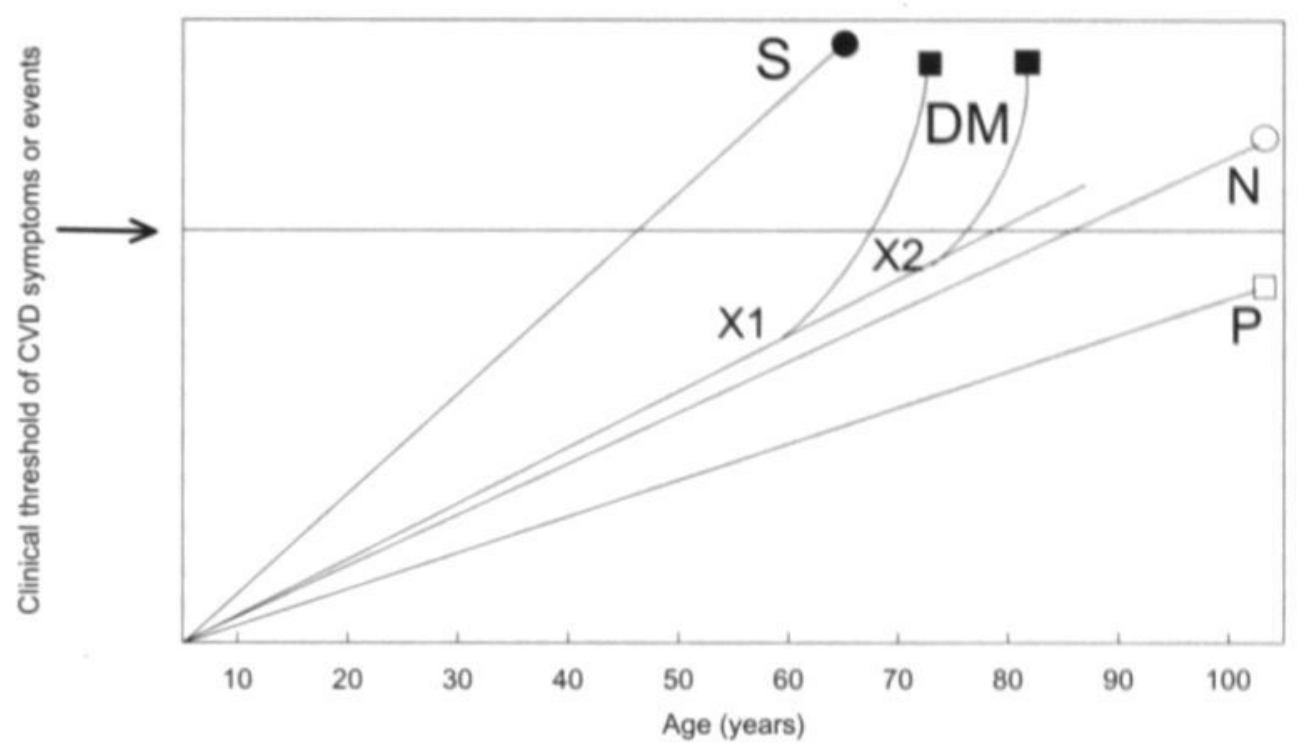

Figure 1: Hypothetical relationship between age and cardiovascular events for different situations. $\mathrm{P}=$ protected $(\square) ; \mathrm{N}=$ normal $(\mathrm{O})$; $\mathrm{DM}=$ diabetes $(\mathbf{\square}) ; \mathrm{S}=$ susceptible for cardiovascular events, for example subjects with familial hypercholesterolemia $(\bullet)$; the horizontal line represents the threshold at which cardiovascular events become clinically manifest

\subsection{Technical considerations}

\subsection{1: Diagnosis and treatment of type 2 diabetes}

Early diagnosis of type 2 diabetes and proper treatment may reduce, or even prevent, future CVD events. For an early diagnosis or type 2 diabetes, we recommend screening for diabetes of every hypertensive patient, especially those with a high pulse pressure. This screening can be very useful and cost effective because we showed in Chapter 6 that $\sim 40 \%$ of the subjects with a pulse pressure $\geq 67 \mathrm{mmHg}$ had type 2 diabetes, with a resulting odds ratio of 2.1 compared to subjects with a pulse pressure $\leq 48 \mathrm{mmHg}$. Capillary glucose measurements may be used for this screening because they are relatively easy to use and fairly cheap compared to venous glucose measurements. 
Moreover, we showed in Chapter 4 that sensitivity and specificity of these measurements were high enough to detect type 2 diabetes in a reliable manner.

Several landmark studies have shown a beneficial effect of treatment of one risk factor with medication on the cardiovascular risk in type 2 diabetes (47-49). Moreover, several programs that aimed at changing lifestyle, with or without added medication, already showed that progression from IGT to type 2 diabetes can be reduced or delayed (49-53). That a combination of treatments, beneficial to all cardiovascular risk factors, is to be recommended in type 2 diabetes was recently demonstrated by the STENO-2 study $(54,55)$. In the STENO-2 study, multiple risk factors were treated at the same time (behaviour modifications, as well as treatment of hyperglycemia, hypertension, dyslipidemia and microalbuminuria, and giving aspirin) for secondary prevention. The risk of cardiovascular and microvascular events, such as retinopathy, nephropathy, and neuropathy, was reduced by 50 percent $(54,55)$.

\subsection{2: Methods to measure arterial stiffness}

As a large part of the missing values were caused by oscillating movements of the carotid artery, it may be argued that the pulse wave velocity technique (PWV) is a better method than the ultrasound wall track technique to measure arterial stiffness. However, if arterial segments are not straight, measurement of the distance may be a weak and unreliable point in PWV measurements, especially if the proximal and distal pulse waves are recorded from two different arterial axis sites where the pulse waves propagate in opposite directions, such as the carotid and radial artery (26). So, it can be expected that measurements can be obtained in nearly all subjects by this technique, but these measurements may be inaccurate. In the carotid femoral PWV measurement for example, which could have been used as an alternative for ultrasound measurements in the present study, this problem arises (26). In addition, abdominal obesity, particularly in men, and large bust in women can make distance measurements inaccurate (26). As obesity, especially abdominal obesity, is far more prevalent in the type 2 diabetes population, it remains a question whether PWV will result in accurate and valid measurements of arterial stiffness. Therefore, strict validation studies between PWV and ultrasound measurements of arterial stiffness in different populations are urgently needed. These will also have the advantage to facilitate the comparison between studies using either technique. An ultimate solution may be the development of faster ultrasound protocols for carotid artery wall evaluation, because this may solve current problems encountered.

\subsection{3: Blood pressure measurements}

In the CODAM study, arterial vessel wall characteristics were calculated with pulse pressure (PP) measured at the brachial artery as a substitute for carotid artery PP. Blood pressure measured at the brachial artery can deviate from blood pressure measured at the carotid artery although (the few) available data suggest that the differences are relatively small. For example, in a study by Waddell et al., brachial blood pressures measured with a Dinamap were only $8 \mathrm{mmHg}$ higher than carotid blood pressures measured with applanation tonometry in normal subjects (56). Applanation tonometry allows non-invasive recording of the arterial pressure waveform 
and magnitude in both central and peripheral arteries (26). The difference between brachial and carotid blood pressure was lower in subjects with moderate and severe coronary heart disease, 6.5 and $2.6 \mathrm{mmHg}$, respectively. This indicates that distensibility, compliance and Young's elastic modulus may have been underestimated when measuring PP in the brachial artery instead of using applanation tonometry to measure pressure in the carotid artery. However, some controversy exists about measuring blood pressure by applanation tonometry. It has been shown that overestimation is a possibility and several investigators found the magnitude of PP obtained by applanation tonometry to be unreliable (27). Moreover, applanation tonometry can not be applied to all subjects and at all arterial sites (57).

Another method to measure local PP uses a transfer function from the pressure wave measured at an other site (58). However, from the radial artery PP, only carotid arteries and ascending aorta PP can be assessed by this technique (27). Furthermore, the transfer function is an average over many subjects which may lead to loss of specific information of individuals. Therefore, this technique seems to be limited.

PP differences between central and peripheral arteries tend to decrease with aging (59). Therefore, it is unlikely that possible differences between brachial PP measured in the present study and the actual carotid PP would have resulted in other conclusions than presented in this thesis, because subjects were mostly elderly (mean age $59.1 \pm$ 7.0 yrs). Moreover, over- or underestimation of distensibility, compliance and YEM by using brachial PP has been systematically similar in all subjects in this study. This fact enabled comparison between subjects with type 2 diabetes and with IGT or NGT. However, for future studies we recommend that either local PP is measured by applanation tonometry, or that arterial wall properties are compared under isobaric conditions, especially when different populations are compared. Recently, a new promising method to assess local pressure has been published (60). Local pressure waveforms can be derived from arterial cross-sections by iteratively calibrating an exponential relationship between pressure and arterial cross-section to end diastolic and mean arterial pressure (60). This results in an estimate of the wall rigidity (a), but can also be used to derive PWV, YEM, distensibility and compliance as a function of the distending pressure during the cardiac cycle. A large advantage is that this method can be applied to any artery in the arterial tree. Therefore, this method seems very suitable to compare arterial wall properties under isobaric conditions between different populations.

\section{7: Conclusions}

In this thesis, we showed that capillary glucose measurements can result in more costeffective inclusion schemes in screening studies than venous glucose measurements. Furthermore, several pieces of evidence were identified to support the theory that a higher incidence of cardiovascular disease in type 2 diabetes can be related to an accelerated course of atherosclerosis and vessel wall abnormalities. IMT is not increased in subjects with type 2 diabetes when recently diagnosed, but may accelerate during the diabetic state. Arterial wall stiffness however, is already increased at diagnosis of type 2 diabetes. 
The present data, when confirmed by others or in longitudinal studies, provide a positive perspective to the early treatment of implicated risk factors in type 2 diabetes. Specifically, hyperglycemia remains an obvious target for treatment whereas hypertension and fatty acid abnormalities appear to be the most relevant new targets.

No differences seem to exist in the prevalence of cardiovascular events between subjects with and without diabetes in the CODAM study when diagnosed in an early stage. This observation emphasizes the importance of early detection of type 2 diabetes and appropriate treatment of cardiovascular risk factors, especially in subjects at high risk of developing type 2 diabetes and cardiovascular disease.

\section{References}

1. World Health Organization: Definition, diagnosis and classification of diabetes mellitus and its complications (1999) Report of a WHO Consultation. Part 1: Diagnosis and classification of diabetes mellitus. WHO Technical Report Series; 1-59

2. Laakso M, Lehto S. Epidemiology of macrovascular disease in diabetes. Diabetes Rev 1977; 5: 294-315

3. Zimmet $P$. The burden of type 2 diabetes: are we doing enough? Diabetes Metab 2003; 29: 9-18

4. Expert Panel on Detection, Evaluation, and Treatment of High Blood Cholesterol in Adults. Executive Summary of The Third Report of The National Cholesterol Education Program (NCEP) Expert Panel on Detection, Evaluation, and Treatment of High Blood Cholesterol In Adults (Adult Treatment Panel III). JAMA 2001; 285: 2486-2497

5. Solnica B, Naskalski JW, Sieradzki J. Analytical performance of glucometers used for routine glucose self -monitoring of diabetic patients. Clin Chim Acta 2003; 331:29-35

6. Rheney CC, Kirk JK. Performance of three blood glucose meters. Ann Pharmacother 2000; 34(3):317-21

7. Fujimoto WY. Background and recruitment data for the U.S. Diabetes Prevention Program. Diabetes Care 2000; 23 Suppl 2:B11-3

8. The Expert Committee on the Diagnosis and Classification of Diabetes Mellitus. Report of the Expert Committee on the Diagnosis and Classification of Diabetes Mellitus. Diabetes Care 1997; 20:1183-97

9. The Expert Committee on the Diagnosis and Classification of Diabetes Mellitus. Follow -up report on the diagnosis of diabetes mellitus. Diabetes Care 2003; 26: 3160-3167

10. Davidson MB, Landsman PB, Alexander $\mathrm{CM}$. Lowering the criterion for impaired fasting glucose will not provide clinical benefit. Diabetes Care 2003; $26: 3329-3330$

11. Genuth S. Lowering the criterion for impaired fasting glucose is in order. Diabetes Care 2003; 26 : 3331-3332

12. Schriger DL, Lorber $B$. Lowering the cut point for impaired fasting glucose. Where is the evidence? Where is the logic? Diabetes Care 2004; 27: 592-595

13. Bots ML, Grobbee DE. Intima media thickness as a surrogate marker for generalized atherosclerosis. Cardiovascular Drugs and Therapy 2002; 16: 341-351

14. Brownlee M, Vlassara $H$, Cerami A. Nonenzymatic glycosylation products on collagen covalently trap low-density lipoprotein. Diabetes 1985; 34: 938-941

15. Camejo G, Olsson U. Hurt-Camejo E, Baharamian N, Bondjers G. The extracellular matrix on atherogenesis and diabetes -associated vascular disease. Atherosclerosis Suppl 2002; 3: 3-9

16. Swislocki AL, Chen YD, Golay A, Cheng MO, Reaven GM. Insulin suppression of plasma-free fatty acid concentration in normal individuals and patients with type 2 (non-insulin-dependent) diabetes. Diabetologia 1987; 30: 622-626

17. Claire M, Jacotot $B$, Robert L. Characterization of lipids associated with macromolecules of the intercellular matrix of human aorta. Connect Tissue Res 1976; 4: 61-71 
18. Hodis HN, Mack WJ, LaBree L, Selzer RH, Liu CR, Liu CH, Azen SP. The role of carotid arterial intima-media thickness in predicting clinical coronary events. Ann Intern Med 1998; 128: 262-269

19. Arnett DK, Evans GW, Riley WA. Arterial stiffness: a new cardiovascular risk factor? Am J Epidemiol 1994; 140: 669-682

20. Bots ML, Dijk JM, Oren A, Grobbee DE. Carotid intima-media thickness, arterial stiffness and risk of cardiovascular disease: current evidence. J Hypertens 2002; 20: 2317-2325

21. Hoeks APG, Brands PJ, Smeets FAM, Reneman RS. Assessment of the distensibility of superficial arteries. Ultrasound Med Biol 1990; 16: 121-128

22. Liang YL, Shiel LM, Teede H, Kotscpoulos D, McNeil J, Cameron JD, McGrath BP. Effects of blood pressure, smoking, and their interaction on carotid artery structure and function. Hypertension 2001; 37: 6-11

23. Tounian P, Aggoun Y, Dubern B, Vari.lle V, Guy-Grand B, Sidi D, Girardet JP, Bonnet D. Presence of increased stiffness of the common carotid artery and endothelial dysfunction in severely obese children: a prospective study. Lancet 2001; 358: 1400-1404

24. Blacher J, Pannier B, Guerin AP, Marchais SJ, Safar ME, London GM. Carotid arterial stiffness as a predictor of cardiovascular and all-cause mortality in end-stage renal disease. Hypertension 1998; 32: $570-574$

25. Barenbrock M, Kosch M, Joster E, Kisters K, Rahn KH, Hausberg M. Reduced arterial distensibility is a predictor of cardiovascular dsease in patients after renal transplantations. J Hypertens 2002; 20: $79-84$

26. Van Bortel LM, Duprez D, Starmans-Kool MJ, Safar ME, Giannattasio C, Cockcroft J, Kaiser DR, Thuillez C. Clinical applications of arterial stiffness, Task Force III: recommendations for user procedures. Am J Hypertens 2002; 15: 445-452

27. Chen G.H, Ting GT, Nussbacher A, Nevo E, Kass DA, Pak P, Wang S.P, Chang MS, Yin FCP: Validation of carotid artery tonometry as a means of estimating augmentation index of ascending aortic pressure. Hypertension 1996; $27: 168-175$

28. Temelkova-Kurktschiev TS, Koehler C, Leonhardt W, Schaper F, Henkel E, Siegert G, Hanefeld M. Increased intimal-medial thickness in newly detected type 2 diabetes: risk factors. Diabetes Care 1999; 22: 333-338

29. Niskanen L, Rauramaa R, Miettinen H, Haffner SM, Mercuri M, Uusitupa M. Carotid artery intimamedia thickness in elderly patients with NIDDM and in nondiabetic subjects. Stroke 1996; 27 : 1986 1992

30. Bonora E, Tessari R, Micciolo R, Zenere M, Targher G, Padovani R, Falezza G, Muggeo M. Intimal-medial thickness of the carotid artery in nondiabetic and NIDDM patients. Relationship with insulin resistance. Diabetes Care 1997; 20: 627-631

31. Wagenknecht LE, D'Agostino RB, Haffner SM, Savage PJ, Rewers M. Impaired glucose tolerance, type 2 diabetes, and carotid wall thickness. Diabetes Care 1998; 21: 1812-1818

32. Montecchi FR, Menzinger G, Lala A. Carotid intima-media thickness in patients with type 2 diabetes and hypercholesterolemia. Diab Nutr Metab 2001; 14: 58-61

33. Güvener N, Tütüncü NB, Tot A, Erbás T. Major determinants of the carotid intima-media thickness in type 2 diabetic patients: Age and Body Mass Index. Endocrine Journal 2000; 47; 525-533

34. Visonà A, Lusiani L, Bonanome A, Beltramello G, Confortin L, Papesso B, Costa F, Pagnan A. Wall thickening of common carotid arteries in patients affected by noninsulin-dependent diabetes mellitus: relationship to microvascular complications. Angiology 1995; 46: 793-799

35. Puja A, Gnasso A, Irace C, Colonna A, Mattioli PL. Common carotid arterial wall thickness in NIDDM subjects. Diabetes Care 1994; 17: 1330-1336

36. Geroulakos G, Ramaswami G, Veller M, Fisher GM, Renton S, Nicolaides A, Waldron HA, Diamond J, Elkeles RS. Arterial wall changes in type 2 diabetic subjects. Diabet Med 1994; 11: 692-695

37. Haffner SM, D'Agostino R, Saad MF, O'Leary DH, Savage PJ, Rewers M, Selby J, Bergman RN, Mykkänen L. Carotid artery atherosclerosis in type-2 diabetic and nondiabetic subjects with and 
without symptomatic coronary artery disease (The Insulin Resistance Atherosclerosis Study). Am J Cardiol 2000; 85: 1395-1400

38. Hunt KJ, Williams K, Rivera D, O'Leary DH, Haffner SM, Stern MP, Gonzalez Villalpando C. Elevated carotid artery intima-media thickness levels in individuals who subsequently develop type 2 diabetes. Arterioscler Thromb Vasc Biol 2003; 23: 1845-1850

39. Henry RMA, Kostense PJ, Spijkerman AMW, Dekker JM, Nijpels G, Heine RJ, Kamp O, Westerhof $\mathrm{N}$, Bouter LM, Stehouwer CDA. Arterial stiffness increases with deteriorating glucose tolerance status. The Hoorn Study. Circulation 2003; 107: 2089-2095

40. Haffner SM, Lehto S, Ronnemaa T, Pyorala K, Laakso M. Mortality from coronary heart disease in subjects with type 2 diabetes and in nondiabetic subjects with and without prior myocardial infarction. N Engl J Med 1998; 339: 229-234

41. Grundy SM, Benjamin IJ, Burke GL, Chait A, Eckel RH, Howard BV, Mitch W, Smith SC, Sowers JR. Diabetes and cardiovascular disease. A statement for healthcare professionals from the American Heart Association. Circulation 1999; 100: 1134-1146

42. Mensink M, Blaak EE, Baak MA van, Wagenmakers AJ, Saris WH. Plasma free fatty acid uptake and oxidation are already diminished in subjects at high risk for developing type 2 diabetes. Diabetes 2001; 50: 2548-2554

43. Roden M, Price TB, Perseghin G, et al. Mechanism of free fatty acid-induced insulin resistance in humans. J Clin Invest 1996; 97: 2859-2865

44. Fagot-Campagna A, Balkau B, Simon D, et al. High free fatty acid concentration: an independent risk factor for hypertension in the Paris Prospective Study. Int J Epidemiol 1998; 27 808-813

45. Voors-Pette C, de Bruin TW. Excess coronary heart disease in Familial Combined Hyperlipidemia, in relation to genetic factors and central obesity. Atherosclerosis $2001 ; 157: 481-489$

46. Scuteri A, Najjar SS, Muller DC, Andres R, Hougaku H, Metter EJ, Lakatta EG. Metabolic syndrome amplifies the age-associated increases in vascular thickness and stiffness. J Am Coll Cardiol 2004; 43: $1388-1395$

47. Lindholm LH, Dahlöf B, Edelman JM, Ibsen H, Borch-Johnsen K, Hecht Olsen M, Snapinn S, Wachtell K. Effect of losartan on sudden cardiac death in people with diabetes: data from the LIFE study. Lancet 2003; 362: 619-620

48. Diabetes Atherosclerosis Intervention Study Investigators. Effect of fenofibrate on progression of coronary-artery disease in type 2 diabetes: the Diabetes Atherosclerosis Intervention Study, a randomised study. Lancet 2003; 357: 905-910

49. Knowler WC, Barrett-Connor E, Fowler SE, Hamman RF, Lachin JM, Walker EA, Nathan DM. Reduction in the incidence of type 2 diabetes with lifestyle intervention or metformin. N Engl J Med 2002; 346: 393-403

50. Pan XR, Li GW, Hu YH,Wang JX, Yang WY, An ZX, Hu ZX, Lin J, Xiao JZ, Cao HB, Liu PA, Jiang $X G$. Jiang YY, Wang JP, Zheng H, Zhang H, Bennett PH, Howard BV. Effects of diet and exercise in preventing NIDDM in people with impaired glucose tolerance. The Da Qing IGT and Diabetes Study. Diabetes Care 1997; 20: 537-544

51. Eriksson KF, Lindgarde F. Prevention of type 2 (non-insulin-dependent) diabetes mellitus by diet and physical exercise. The 6-year Malmo feasibility study. Diabetologia 1991; 34: 891-898

52. Eriksson KF, Lindgarde F. No excess 12-year mortality in men with impaired glucose tolerance who participated in the Malmo Preventive Trial with diet and exercise. Diabetologia 1998; 41: 1010-1016

53. Tuomilehto J, Lindstrom J, Eriksson JG, Valle $\Pi$, Hamalainen H, llanne-Parikka P, KeinanenKiukaanniemi S, Laakso M, Louheranta A, Rastas M, Salminen V, Uusitupa M. Prevention of type 2 diabetes mellitus by changes in lifestyle among subjects with impaired glucose tolerance. N Engl J Med 2001; 344: 1343-1350

54. Gaede P, Vedel P, Parving HH, Pedersen O. Intensified multifactorial intervention in patients with type 2 diabetes mellitus and microalbuminuria: the Steno type 2 randomised study. Lancet 1999; 353: 617-622 
55. Gaede $P$, Vedel $P$, Larsen $N$, Jensen GVH, Parving $\mathrm{HH}$, Pedersen $\mathrm{O}$. Multifactorial intervention and cardiovascular disease in patients with type 2 diabetes. N Engl J Med 2003; 348: 383-393

56. Waddell TK, Dart AM, Medley TL, Cameron JD, Kingwell BA. Carotid pressure is a better predictor of coronary artery disease severity than brachial pressure. Hypertension 2001; 38: $927-931$

57. Nichols WW, O'Rourke M. McDonald's Blood Flow in Arteries: Theoretical, Experimental and Clinical Principles. 1998; 4th ed. Edward Amold, London

58. Chen C.H, NevoE, Fetics B, Pak PH, Yin FCP, Maughan WL, Kass DA: Estimation of central aortic pressure waveform by mathematical transformation of radial tonometry pressure. Circulation 1997; 95: $1827-1836$

59. Benetos A, Waeber B, Izzo J, Mitchell G, Resnick L, Asmar R, Safar M. Influence of age, risk factors, and cardiovascular and renal disease on arterial stiffness: clinical applications. Am J Hypertension 2002; 15: 1101-1108

60. Meinders JM, Hoeks APG. Simultaneous assessment of diameter and pressure waveforms in the carotid artery. Ultrasound in Med \& Biol 2004; 30: 147-154 
Summary - Samenvatting 
Chapter 1 describes the background and aims of this thesis. Type 2 diabetes mellitus is the most common form of diabetes and is estimated to increase in a pandemic manner over the next 10 to 20 years (1). Although the early symptoms are often not severe, the long-term effects of hyperglycemia result in, or are associated with, microand macrovascular disease like retinopathy, neuropathy, and atherosclerosis $(2,3)$. Ultimately, this can lead to blindness, renal failure, and cardiovascular events such as myocardial infarction and stroke. Different risk scores have been developed to enable physicians to calculate an individual's risk on future cardiovascular events and initiate appropriate treatment (4-7).

The atherosclerosis process is often slow and principally occurs in large and medium-sized arteries. Two theories exist nowadays to explain the process of atherosclerosis, i.e. the response-to-injury hypothesis and the response-to-retention hypothesis. The response-to-injury hypothesis states that atherosclerosis is a process of endothelial injury or activation and of inflammation. Hyperlipidemia, endothelial dysfunction and permeability, blood flow, and ipoprotein oxidation are thought to be causes of the early atherosclerosis process. In contradiction with this theory, the response-to-retention hypothesis states that lipid retention in the arterial wall is the key pathogenic event that is necessary for the formation of an atherosclerotic lesionm, and hyperlipidemia, lipoprotein modification, turbulent blood flow and alterations in endothelium, smooth muscle cells and the matrix only contribute to the atherosclerosis process. Both theories have their merit. However, recent findings favour the responseto-retention hypothesis (8). Factors such as hyperlipidemia, smoking, hypertension, turbulent blood flow and lipoprotein oxidation can increase the harmful effects of lipid retention in the arterial wall and contribute to the development of an atherosclerotic lesion into an atherosclerotic plaque. The response-to-injury theory may be more appropriate to describe the development to an unstable vulnerable plaque (9).

As the nature of the atherosclerosis process is slow, surrogate markers such as intima-media thickness and arterial stiffness measurements have been used to investigate determinants of atherosclerosis at an early stage and/or to assess disease modifiers (10). Prospective studies have shown that both intima-media thickness and arterial stiffness can be used as good indicators of cardiovascular risk (11).

Type 2 diabetes mellitus and cardiovascular disease share common risk factors. Clustering of several of these risk factors is common and is recently defined as the metabolic syndrome (12). As the presence of type 2 diabetes increases the cardiovascular risk two to four times, it is crucial to understand how atherosclerosis develops and progresses in subjects with type 2 diabetes. There is evidence that subjects in the pre-diabetic state are already at high risk for cardiovascular events (3) and early detection of insulin resistance is likely to identify those persons who are at risk of developing dyslipidemia, hypertension, and ultimately diabetes.

Chapter 2 describes the subjects, methods, and design of the CODAM study, as well as some results. We showed that hyperglycemia is associated with a number of metabolic and vascular abnormalities. Furthermore, significantly more target damage at the level of the large vessels and kidneys was found in subjects with type 2 diabetes, as well as increased inflammatory markers. Therefore, we concluded that subjects with recently diagnosed type 2 diabetes were already at increased cardiovascular risk and 
even showed some vascular damage. This was mostly due to, or associated with, metabolic abnormalities.

Chapter 3 presents the results of the preliminary screening of the CODAM and SLIM study ( $\mathrm{N}=2820$ subjects). Abnormal glucose homeostasis was found in 826 subjects $(30.4 \%): 226$ subjects had type 2 diabetes mellitus $(8.3 \%), 385$ subjects had impaired glucose tolerance $(14.2 \%)$, and 215 subjects had impaired fasting glucose $(7.9 \%)$. Increasing age and BMI were both positively related to the prevalence of type 2 diabetes and impaired glucose tolerance. The high prevalence of disturbances in glucose homeostasis underscores the importance of early interventions in those at risk for developing diabetes.

Chapter 4 presents the results of a comparative study between capillary blood glucose measurements done with a Glucometer Elite® and venous blood glucose measurements determined in our laboratory. We showed that capillary glucose measurements are reliable and sufficiently precise to detect subjects with normal glucose tolerance and type 2 diabetes mellitus. Subjects with impaired glucose tolerance could not be diagnosed as reliably with capillary glucose measurements. Nevertheless, use of capillary glucose measurements resulted in a more favourable ratio of screened and detected subjects with impaired glucose tolerance in our study compared to the situation where other inclusion procedures were used.

Chapter $\mathbf{5}$ showed that intima-media thickness of the common carotid artery was similar among subjects with recently diagnosed type 2 diabetes, impaired glucose tolerance and normal glucose tolerance. Pulse pressure and carotid diameter, but not the pre-diabetic state or type 2 diabetes, were independent contributors to IMT. On the other hand, an apparent acceleration occurs in IMT thickening in subjects with type 2 diabetes when data were used from a similar cohort study with older subjects and included subjects with diabetes of longer duration. In the interpretation of these data, it should be recognized that IMT is not a static measure but is subject to remodelling. This suggested that a substantial part of the increase in IMT occurs during the diabetic state and may be prevented.

Arterial stiffness, represented by Young's elastic modulus, was already increased in subjects with recently diagnosed type 2 diabetes. Furthermore, is seems that the increase in arterial stiffness is accelerated in subjects with type 2 diabetes compared to subjects with normal glucose tolerance. Clustering of several risk factors, including hypertension, obesity and total cholesterol, against a background of hyperglycemia, may play an important role in the increase in arterial stiffness. Follow up studies are needed to confirm our initial estimates of accelerated increase in intima-media thickening and arterial stiffness as well as the effect of medication or lifestyle intervention on the prevention of future cardiovascular events.

Chapter 6 showed that increased pulse pressure is not only associated with hypertension and left ventricular hypertrophy, but also with serious clinical metabolic disorders such as type 2 diabetes mellitus and the metabolic syndrome, as well as other metabolic abnormalities, specifically increased plasma concentrations of glucose, fatty acids, and insulin. In the highest pulse pressure quartile ( $\geq 67 \mathrm{~mm} \mathrm{Hg}$ ), $39.4 \%$ of 
subjects had type 2 diabetes whereas more than half of the study population (51.4\%) had metabolic syndrome according to the National Cholesterol Education Program (NCEP) definition (12). Plasma free fatty acids were identified as a novel, independent, metabolic determinant of pulse pressure in multivariate regression analysis, in addition to age, gender, carotid intima-media thickness and diameter, waist circumference, ankle/brachial index and mean arterial pressure. Several data suggested that an increase of free fatty acids can increase blood pressure (13-15), and a prospective association between plasma free fatty acids and the development of hypertension has been shown (16). Moderately elevated plasma free fatty acids in subjects with high pulse pressure can therefore reflect an underlying, pivotal metabolic abnormality involved in the observed association of hypertension with diabetes and the metabolic syndrome.

Chapter 7 discusses the main results and puts them into perspective. Furthermore, a hypothetical model about the relationship between type 2 diabetes and cardiovascular complications is described. Suggestions for future research are made.

\section{References}

1. Zimmet $P$. The burden of type 2 diabetes: are we doing enough? Diabetes Metab 2003; 29: 9-18

2. World Health Organization: Definition, diagnosis and classification of diabetes mellitus and its complications (1999) Report of a WHO Consultation. Part 1: Diagnosis and classification of diabetes mellitus. WHO Technical Report Series; 1-59

3. Haffner SM, Stern MP, Hazuda HP, Mitchell BD, Patterson JK. Cardiovascular risk factors in confirmed prediabetic individuals: does the clock for coronary heart disease start ticking before the onset of clinical diabetes? JAMA 1990; 263: 2893-2898

4. Vogel RA, Benitez RM. Noninvasive assessment of cardiovascular risk: from Framingham to the future. Rev Cardiovasc Med 2000; 1: 3442

5. Conroy RM, Pyörälä K, Fitzgerald AP, Sans S, Menotti A, De Backer G, De Bacquer D, Ducimetière P, Jousilahti P, Keil U, Njolstad I, Oganov RG, Thomsen T, Tunstall-Pedoe H, Tverdal A, Wedel H. Whincup P. Wilhelmsen L, Graham IM. Estimation of ten-year risk of fatal cardiovascular disease in Europe: the SCORE project. Eur Heart J 2003; 24: $987-1003$

6. De Visser CL, Bilo HJB, Thomsen TF, Groenier KH, Meyboom-De Jong B. Prediction of coronary heart disease: a comparison between the Copenhagen risk score and the Framingham risk score applied to a Dutch population. J Intern Med 2003; 253:553-562

7. Assmann G, Cullen P, Schulte $\mathrm{H}$. Simple scoring scheme for calculating the risk of acute coronary events based on the 10-year follow -up of the Prospective Cardiovascular Münster (PROCAM) Study. Circulation 2002; 105: 310-315

8. Williams KJ, Tabas I. The response-to-retention hypothesis of early atherogenesis. Arterioscler Thromb Vasc Biol 1995; 15: 551-561

9. Corti R, Farkouh ME, Badimon JJ. The vulnerable plaque and acute coronary syndromes. Am J Med 2002; 113: 668-680

10. Wittes J, Lakatos J, Probstfeld J. Surrogate endpoints in clinical trials. Stat Med 1989; 8: 415-425

11. Bots ML, Dijk JM, Oren A, Grobbee DE. Carotid intima-media thickness, arterial stiffness and risk of cardiovascular disease: current evidence. J Hypertens 2002; 20: 2317-2325

12. Expert Panel on Detection, Evaluation, and Treatment of High Blood Cholesterol in Adults. Executive Summary of The Third Report of The National Cholesterol Education Program (NCEP) Expert Panel on Detection, Evaluation, and Treatment of High Blood Cholesterol In Adults (Adult Treatment Panel III). JAMA 2001; 285: 2486-2497 
13. Van der Kallen CJH, Voors-Pette C, Bouwman FG, et al. Evidence of insulin resistant lipid metabolism in adipose tissue in familial combined hyperlipidemia, but not type 2 diabetes mellitus. Atherosclerosis 2002; 164: 337-346

14. Allayee H, de Bruin TW, Michelle Dominguez K, et al. Genome scan for blood pressure in Dutch dyslipidemic families reveals linkage to a locus on chromosome 4p. Hypertension 2001; 38: 773 778

15. Baron $A D$. Insulin resistance and vascular function. J Diabetes Complications 2002; 16: 92-102

16. Fagot-Campagna A, Balkau B, Simon D, et al. High free fatty acid concentration: an independent risk factor for hypertension in the Paris Prospective Study. Int J Epidemiol 1998; 27 808-813 
In Hoofdstuk 1 wordt de achtergrond van dit proefschrift beschreven. Type 2 diabetes mellitus, of ouderdomssuikerziekte, is de meest voorkomende vorm van diabetes. De schatting is dat de prevalentie van type 2 diabetes pandemisch zal gaan stijgen in de aankomende 10 tot 20 jaar. Hoewel de symptomen in het begin vaak niet ernstig zijn kunnen de lange termijn effecten van chronische hyperglycemie leiden tot micro- en macrovasculaire ziektes zoals retinopathie, neuropathie en atherosclerose. Uiteindelijk kunnen deze ziektes leiden tot blindheid, nierfalen en cardiovasculaire complicaties zoals een hartinfarct of beroerte. Er zijn verschillende formules ontwikkeld om het risico van een patiënt op hart- en vaatziektes in de toekomst te berekenen zodat de patiënt op de juiste wijze behandeld kan worden.

Het atherosclerose proces, dat tot hart- en vaatziektes leidt, verloopt vaak langzaam en vindt vooral plaats in de grote en middelgrote arteriën. Momenteel bestaan er twee theorieën die het atherosclerose proces verklaren, namelijk de response-to-injury (respons-op-verwonding) hypothese en de response-to-retention (respons-op-vasthouden) hypothese. De response-to-injury hypothese verkondigd dat atherosclerose een proces is veroorzaakt door beschadiging en activatie van het endotheel en van ontstekingsprocessen. Hyperlipidemie, endotheel dysfunctie and permeabiliteit, bloedstroming, and lipoproteïne oxidatie worden aangewezen als oorzaken van het vervroege atherosclerose proces. In tegenstelling met deze theorie verkondigt de response-to-retention hypothese dat lipide retentie in de arteriële vaatwand de pathogene sleutel gebeurtenis is die nodig is voor de vorming van een atherosclerotische lesie en dat hyperlipidemie, lipoproteïne modificatie, turbulente bloedstroming en veranderingen in het endotheel, de gladde spiercellen en de matrix alleen bijdragen aan het atheroslerotische proces. Beide theorieën hebben hun voordelen. Recente bevindingen echter spreken vóór de respons-to-retention hypothese. Factoren zoals hyperlipidemie, roken, hypertensie, turbulente bloedstroming en lipoproteïne oxidatie kunnen de schadelijke effecten van het vasthouden van vetten in de arteriële wand vergroten en daardoor bijdragen aan de ontwikkeling van een atherosclerotische lesie naar een atherosclerotische plaque. De response-to-injury hypothese is waarschijnlijk geschikter om de ontwikkeling tot een onstabiele kwetsbare plaque te beschrijven.

Omdat het atherosclerose proces langzaam verloopt worden er surrogaat markers zoals intima-media dikte en arteriële stijfheid metingen gebruikt om determinanten van vroege atherosclerose te onderzoeken en om factoren die het verloop van hart- en vaatziektes wijzigen te bepalen. Prospectieve studies hebben aangetoond dat zowel intima-media dikte als arteriële stijfheid goede indicatoren zijn van het risico op hart- en vaatziektes.

Type 2 diabetes en hart- en vaatziektes delen gemeenschappelijke risicofactoren. Over het algemeen komt clustering van verschillende van deze risicofactoren veel voor. Pas geleden is deze clustering gedefinieerd als het metabole syndroom. Omdat de aanwezigheid van type 2 diabetes het risico op hart- en vaatziektes 2 tot 4 keer vergroot is het van cruciaal belang om de ontwikkeling en het verloop van atherosclerose bij personen met type 2 diabetes te begrijpen. Het is tewezen dat mensen in het voorstadium van type 2 diabetes al een verhoogd risico op hart- en vaatziektes hebben en een vroege detectie van insuline resistentie kan hoogstwaarschijnlijk die personen identificeren die het risico lopen om dyslipidemie, hypertensie, en uiteindelijk type 2 diabetes te ontwikkelen. 
Hoofdstuk 2 beschrijt de proefpersonen, onderzoeksmethodes, en de opzet van de CODAM studie alsook enkele resultaten. We toonden aan dat hyperglycemie geassocieerd is met een aantal metabole en vasculaire afwijkingen. Verder werd er significant meer doel orgaan schade gevonden op het nivo van de grote vaten en nieren en werden er verhoogde nivo's van inflammatoire markers gevonden bij mensen met type 2 diabetes. Daardoor kwamen we tot de conclusie dat mensen met recent gediagnostiseerde type 2 diabetes reeds een verhoogd risico op hart- en vaatziektes hebben en zelfs al enige vaatschade vertonen. Dit wordt voornamelijk veroorzaakt door metabole afwijkingen.

In Hoofdstuk 3 worden de resultaten van de voorafgaande screening van de CODAM studie gepresenteerd ( $\mathrm{N}=2820$ proefpersonen). Een afwijkende glucose homeostase werd gevonden bij 826 mensen (30.4\%): 226 personen hadden type 2 diabetes mellitus $(8.3 \%), 385$ personen hadden een verstoorde glucose tolerantie $(14.2 \%)$, en 215 personen hadden een verstoorde nuchtere glucose concentratie $(7.9 \%)$. Toegenomen leeftijd en BMI waren beide positief gerelateerd aan de prevalentie van type 2 diabetes en verstoorde glucose tolerantie. De hoge prevalentie van verstoringen in glucose homeostase onderstreept het belang van vroege interventie in die personen die risico lopen op het ontwikkelen van diabetes.

In Hoofdstuk 4 worden de resultaten gepresenteerd van een vergelijkende studie tussen capillaire bloed glucose metingen bepaald met een Glucometer Elite® en veneuze bloed glucose metingen bepaald in ons laboratorium. We toonden aan dat capillaire glucose metingen betrouwbaar en nauwkeurig genoeg zijn om mensen met normale glucose tolerantie of type 2 diabetes mellitus op te sporen. Mensen met een verstoorde glucose tolerantie konden niet zo betrouwbaar worden opgespoord met capillaire glucose metingen. Niettemin resulteerde het gebruik van capillaire glucose metingen wel in een gunstigere ratio van gemeten personen tov opgespoorde proefpersonen met een verstoorde glucose tolerantie in onze studie vergeleken met een situatie waarin andere inclusie procedures werden gevolgd.

In Hoofdstuk 5 lieten we zien dat de intima-media dikte van de carotis communis arterie gelijk was bij proefpersonen met recent gediagnostiseerde type 2 diabetes, verstoorde glucose tolerantie en normale glucose tolerantie. Polsdruk en de diameter van de carotis, maar niet het voorstadium van type 2 diabetes of type 2 diabetes zelf, droegen onafhankelijk bij aan intima-media dikte. Het lijkt erop dat er een versnelling optreedt in de verdikking van de intima-media bij proefpersonen met type 2 diabetes wanneer we naar de data kijken van een gelijkwaardige cohort studie waarin oudere proefpersonen en proefpersonen met een langere duur van diabetes dan in onze studie zijn ingesloten. Bij de interpretatie van deze data dient rekening te worden gehouden met het feit dat intima-media dikte geen statische maat is, maar onderhevig is aan aanpassingen. Dit suggereert dat een aanzienlijk deel van de toename in intima-media dikte optreedt wanneer type 2 diabetes aanwezig is en dus vroegtijdig voorkomen zou kunnen worden.

Arteriële stijfheid, vertegenwoordigd door Young's elastische modulus, was reeds toegenomen bij proefpersonen met recent gediagnostiseerde type 2 diabetes. Verder 
lijkt het erop dat de toename in arteriële stijfheid versneld is bij personen met type 2 diabetes vergeleken met mensen met een normale glucose tolerantie. Clustering van verschillende risicofactoren waaronder hypertensie, overgewicht en totale cholesterol concentratie tegen een achtergrond van hyperglycemie zou een belangrijke rol kunnen spelen in de toename van arteriële stijfheid. Vervolgstudies zijn nodig om onze eerste schatting van versnelde intima-media verdikking en toename van arteriële stijfheid alsmede het effect van medicatie of leefstijl interventies op de preventie van toekomstige hart- en vaatziektes te bevestigen.

Hoofdstuk 6 liet zien dat een verhoogde polsdruk niet alleen samenhangt met hypertensie en linker ventrikel hypertrofie, maar ook met andere ernstige klinische metabole stoornissen zoals type 2 diabetes mellitus en het metabool syndroom, alsook met metabole afwijkingen, in het bijzonder verhoogde plasma concentraties van glucose, vetzuren en insuline. In het hoogste polsdruk kwartiel ( $\geq 67 \mathrm{mmHg}$ ) was $39.4 \%$ van de proefpersonen diabeet terwijl meer dan de helft van de studie populatie (51.4\%) aan het metabool syndroom leed volgens de definitie van het National Cholesterol Education Program (NCEP). Naast leeftijd, geslacht, intima-media dikte en diameter van de carotis, middelomtrek, enkel/arm index en de gemiddelde arteriële druk werden plasma vrije vetzuren geïdentificeerd als een nieuwe, onafhankelijke, metabole determinant van polsdruk in meervoudige regressie analyse. Verschillende data suggereerde dat een toename van vrije vetzuren de bloeddruk kan laten toenemen, en een prospectieve associatie tussen plasma vrije vetzuren en de ontwikkeling van hypertensie is aangetoond. Middelmatig toegenomen plasma vrije vetzuren bij personen met een hoge polsdruk kunnen daarom een onderliggende, centrale metabole abnormaliteit weerspiegelen die betrokken kan zijn bij de geobserveerde associatie van hypertensie met diabetes en het metabool syndroom.

In Hoofdstuk 7 worden de belangrijkste resultaten besproken en vergeleken met resultaten van ander onderzoek. Verder wordt er een hypothetisch model beschreven over de relatie tussen type 2 diabetes en cardiovasculaire complicaties en worden er suggesties gegeven voor toekomstig onderzoek. 
Curriculum Vitae 


\section{Curriculum Vitae}

Margriet Kruijshoop was born on June 30th, 1974, in Hengelo (the Netherlands). After completing secondary school in 1993 at the "Bataafse Kamp" in Hengelo, she started to study Health Sciences at Maastricht University and specialized in Movement Sciences. During her internship, Margriet worked under supervision of Dr. LJC van Loon and Prof. Dr. WHM Saris on a research project on glycogen resynthesis rates following ingestion of different carbohydrate/protein mixtures. Subsequently, she worked as a research assistant on free carnitine availability and fat oxidation during incremental exercise. In September 1998, she graduated as Master of Science. In March 1999, she started her PhD thesis project at Maastricht University at the Department of Medicine, in the Cardiovascular Research Institute Maastricht (CARIM), and worked on the research project "Relevance of genetic predisposition and lifestyle on the pathogenesis of type 2 diabetes mellitus and cardiovascular complications" under supervision of Prof. Dr. TWA de Bruin, Dr. EE Blaak and Dr. EJM Feskens. Part of the results of this project have been described in this thesis. Margriet is currently working as a researcher at the Department of Surgery, Maastricht University.

Margriet Kruijshoop werd geboren op 30 juni 1974 in Hengelo. Na afronding van het middelbaar onderwijs (atheneum) in 1993 op de "Bataafse Kamp" in Hengelo begon ze aan de studie Gezondheidswetenschappen aan de Universiteit van Maastricht en volgde de afstudeerrichting Bewegingswetenschappen. Tijdens haar stage werkte Margriet onder begeleiding van Dr. LJC van Loon en Prof. Dr. WHM Saris aan een onderzoeksproject over glycogeen resynthese snelheid na inname van verschillende koolhydraat/eiwit mixen. Vervolgens werkte ze als onderzoeks-assistent aan vrije carnitine beschikbaarheid en vet oxidatie tijdens inspanning. In September 1998 studeerde ze af als Doctorandus in de Gezondheidswetenschappen. In maart 1999 begon ze als assistent in opleiding aan de Faculteit Geneeskunde van de Universiteit van Maastricht bij het Cardiovascular Research Institute Maastricht (CARIM) en werkte aan het onderzoeksproject "Relevantie van genetische predispositie en leefstijl op de pathogenese van type 2 diabetes mellitus en cardiovasculaire complicaties" onder begeleiding van Prof. Dr. TWA de Bruin, Dr. EE Blaak en Dr. EJM Feskens. Een deel van de resultaten van dit project staan beschreven in dit proefschrift. Op dit moment werkt Margriet als onderzoeker bij de capaciteitsgroep Algemene Heelkunde aan de Universiteit Maastricht. 


\section{List of publications}




\section{Full papers}

Luc JC van Loon, Wim HM Saris, Margriet Kruijshoop, Anton JM Wagenmakers. Maximizing postexercise muscle glycogen synthesis: carbohydrate supplementation and the application of amino acid or protein hydrolysate mixtures. Am J Clin Nutr 2000; 72: $106-11$

Luc JC van Loon, Margriet Kruijshoop, Hans Verhagen, Wim HM Saris, Anton JM Wagenmakers. Ingestion of protein hydrolysate and amino acid-carbohydrate mixtures increases postexercise plasma insulin responses in men. J Nutr 2000; 130: 2508-2513

Erik T Keulen, Margriet Kruijshoop, Nicolaas C Schaper, Arnold PG Hoeks, Tjerk WA de Bruin. Increased intima-media thickness in familial combined hyperlipidemia associated with apolipoprotein B. Arterioscler Thromb Vasc Biol 2002; 22: 283-288

Luc JC van Loon, Margriet Kruijshoop, Paul PCA Menheere, Anton JM Wagenmakers, Wim HM Saris, Hans A Keizer. Amino acid ingestion strongly enhances insulin secretion in patients with long-term type 2 diabetes. Diabetes Care 2003; 26: 625-630

Marco Mensink, Edith JM Feskens, Margriet Kruijshoop, Tjerk WA de Bruin, Wim HM Saris, Ellen E Blaak. Subscapular skinfold thickness distinguishes between transient and persistent impaired glucose tolerance: Study on Lifestyle-Intervention and Impaired Glucose Tolerance Maastricht (SLIM). Diabet Med 2003; 20: 552-557

Marco Mensink, Eva Corpeleijn, Edith JM Feskens, Margriet Kruijshoop, Wim HM Saris, Tjerk WA de Bruin. Study on lifestlyle-intervention and impaired glucose tolerance Maastricht (SLIM): design and screening results. Diabetes Res Clin Pract 2003; 61: 49 58

Margriet Kruijshoop, Edith JM Feskens, Ellen E Blaak, Tjerk WA de Bruin. Validation of capillary glucose measurements to detect glucose intolerance or type 2 diabetes mellitus in the general population: the CoDAM study. Clinica Chimica Acta 2004; 341: $33-40$

M Kruijshoop, CJH van der Kallen, APG Hoeks, EH Lambrichs, EJM Feskens, EE Blaak, TWA de Bruin. Increased aterial stiffness but normal intima-media thickness in recently diagnosed type 2 diabetes mellitus. Submitted

Margriet Kruijshoop, Carla JH van der Kallen, Ellen H Lambrichs, Edith JM Feskens, Tjerk WA de Bruin. Increased pulse pressure is associated with metabolic syndrome and type 2 diabetes. Submitted

Eva Corpeleijn, Carla van der Kallen, Margriet Kruijshoop, Michaël Magagnin, Tjerk W.A. de Bruin, Edith J.M. Feskens, Wim H.M. Saris, Ellen E. Blaak. A promoter 
polymorphism in the CD36/FAT fatty acid transporter gene predisposes to type 2 diabetes mellitus. Submitted

MMJ van Greevenbroek, VMM-J Vermeulen, HJG Bilo, M Kruijshoop, EJM Feskens and TWA de Bruin. Interaction of paraoxonase (PON)1 and thioredoxin interacting protein (TXNIP) genes in type 2 Diabetes Mellitus. Submitted

\section{Abstracts}

Kruijshoop M, Blaak EE, Feskens EJM, van Dam R, Dekker JM, Heine RJ, de Bruin TWA (2000) DIALOG: Prospective cohortstudy for DIAbetes, Lifestyle, Obesity and Genetics. IJO 25 (Suppl. 1): nr. 243

M Kruijshoop, E.E. Blaak, E.J.M. Feskens, R. van Dam, J.M. Dekker, R.J. Heine, T.W.A. de Bruin, H. Jansen, H. Molhuizen, G. Nijpels, C. Stehouwer (2000) Relevance of genetic predisposition and lifestyle factors in the pathogenesis of type 2 diabetes mellitus and cardiovascular complications. Atherosclerosis 151(1): 68, nr MoT6:W1

M Kruijshoop, EE Blaak, EJM Feskens, JM Dekker, R Heine, TWA de Bruin (2001) DIALOG: diabetes, lifestyle, obesity and genetics: preliminary results. IJO 25 (Suppl 2): nr. 237

M Kruijshoop, EJM Feskens, EE Blaak, JM Dekker, RJ Heine, TWA de Bruin (also on behalf of the DIALOG research group) (2002) Validation of capillary glucose measurements to detect type 2 diabetes mellitus in the general population: the CoDAM study. Diabetologia 45 (Suppl 2): A98, nr. 295

SW van den Berg, EHJ Jansen, M Kruijshoop, PK Beekhof, E Blaak, TWA de Bruin, EJM Feskens (2003) Differences in paraoxonase phenotype and genotype between diabetics and non-diabetics (the CODAM study). International Diabetes Federation Congress 2003, Aug 24-29; Paris, France

E Corpeleijn, CJH van der Kallen, M Kruijshoop, M Magagnin, TWA de Bruin, EE Blaak. Association of a polymorphism in the fatty acid transporter CD36 with the prevalence of type 2 diabetes mellitus. European Congress on Obesity 2004, submitted 
Dankwoord 
Ruim 12.000 bloedbuizen, 51.660 cupjes en bijna 72 liter bloed verder ben ik nu eindelijk aan het allerlaatste onderdeel van mijn promotie-onderzoek toegekomen: het dankwoord. De aantallen zeggen het al. Dit project had ik niet kunnen doen zonder de hulp van een heleboel mensen.

Als eerste wil ik alle proefpersonen van de CODAM studie hartelijk danken voor hun vrijwillige (!) medewerking. Zonder jullie hadden we nooit de gegevens gehad waarmee dit proefschrift tot stand is gekomen. Bedankt voor de tijd die jullie vrij wilden maken om aan dit onderzoek mee te doen.

Ten tweede wil ik natuurlijk mijn promotor bedanken, prof. Dr. TWA de Bruin. Tjerk, hartelijk bedankt voor al je goede suggesties en sturing die er van jouw kant kwamen. Toen ik net begon dacht ik dat het overdreven was om minimaal 1 keer in de week af te spreken om je op de hoogte te houden van het reilen en zeilen van het project. Achteraf bleek echter dat het een prima strategie was waardoor je zeer goed wist wat er zich afspeelde tijdens elke fase van het onderzoek. Vooral in de afrondingsfase van dit proefschrift stond je deur altijd open en kon ik altijd even met je van gedachten wisselen over hoe ik de zaken het beste aan kon pakken. Heel veel succes met je nieuwe baan in de Verenigde Staten.

Ook mijn co-promotoren, Dr. EE Blaak en Dr. EJM Feskens, wil ik hartelijk bedanken. Ellen, ondanks je drukke bezigheden ben je altijd geïnteresseerd geweest in hoe het ging met het verzamelen en meten van de proefpersonen, en, toen dit eenmaal afgerond was, hoe het stond met de manuscripten. Je was altijd bereid om artikelen door te lezen en je gestructureerde kijk op de zaken heb ik altijd zeer gewaardeerd. Edith, je werkt bij het RIVM en bent daardoor niet altijd even gemakkelijk bereikbaar. Toch heb ik het idee dat we een goede samenwerking hebben gehad. Onze tripjes van en naar elkaar waren altijd heel informatief en vooral ook gezellig. Je ervaring met statistiek van grote databases heeft zeker bijgedragen aan de kwaliteit van de artikelen on vitoindolijk ook van dit proofoohrift.

Behalve Ellen en Edith ben ik ook Carla van der Kallen veel dank verschuldigd. Carla, het is jammer dat er geen 3 co-promotoren mogen worden benoemd, want ik heb veel gehad aan al je hulp bij statistische analyses en het doorlezen van de manuscripten. Daarnaast konden we ook heerlijk kletsen over van alles en nog wat, iets dat zeker een welkome afwisseling is als je de hele dag naar je beeldscherm zit te kijken!

Ik wil de leden van de beoordelingscommissie hartelijk bedanken voor het vrijmaken van tijd om dit proefschrift door te lezen en goed te keuren.

Andere mensen die van (mentaal) belang zijn geweest voor het slagen van het onderzoeksproject zijn Rob van Dam, Griët Bos en Ronald Henry. Rob, bedankt voor het selecteren van de personen voor de screening uit de MORGEN studie en de gezelligheid op de congressen. Griët, mijn collega- en spiegel-aio aan de VU, bedankt voor het uitwisselen van protocollen en het gedachten wisselen over problemen waar we beide vrijwel tegelijkertijd tegenaan liepen. Ronald, fijn dat er nog een aio was die zoveel proefpersonen moest "echo-en" en met wie ik kon discussiëren over alles wat hiermee te maken heeft, van het protocol tot het doen van de berekeningen aan toe.

Ellen Lambrichs en Eefje Corpeleijn, bedankt dat jullie mijn paranimfen willen zijn op deze bijzondere dag! Ellen, ik ben blij dat ik jou naast me had staan bij het uitvoeren van de echo-metingen, die verreweg de meeste tijd hebben gekost. Samen hebben we geleerd hoe we de metingen moesten doen en kwamen we erachter dat dat lichamelijk, 
en na pakweg een jaar ook mentaal, behoorlijk zwaar kan zijn. Gelukkig konden we elkaar tot het einde toe motiveren om toch nauwkeurig te blijven werken. Zonder jou was het me nooit gelukt om alle metingen te doen. Heel veel dank daarvoor. Daarnaast vond ik het heel gezellig om een tijd je kamergenoot te zijn! Eefje, bedankt voor alle gezelligheid in de kroeg, de fietstochtjes, de culturele avondjes, de vele gezellige saampjes eten avondjes en natuurlijk niet te vergeten de gezellige weekendjes weg waar we net mee begonnen zijn. Ik hoop dat er nog vele avondjes en weekendjes zullen volgen! Verder wil ik je bedanken voor het doorlezen van dit proefschrift in een voor jou erg drukke periode. Heel veel succes met het afronden van jouw proefschrift!

Bijna 600 mensen hebben deelgenomen aan het onderzoek waarop dit proefschrift gebaseerd is. Vrij snel bleek dat we deze nooit allemaal binnen de gestelde tijd zouden kunnen meten en werd besloten dat we studenten in zouden gaan zetten. Aniqa Bashir, Maaike Berbée, Aartje van Kranenburg. Anneke van Lieshout, Anke Pronk, Marjon Smoors, en Janneke Wijnakker, heel erg bedankt voor jullie hulp bij het doen van de suikertesten. In het begin was het misschien nog een beetje eng om te prikken maar uiteindelijk draaiden jullie daar je hand niet meer voor om. Fijn ook dat de meesten van jullie later nog de wetenschapsstage op het MME-lab kwamen lopen. Ik vond het heel bijzonder om jullie ontwikkeling van beginnend student naar beginnend arts mee te maken... Esther de Zwart, Maartje van den Broek en Wietske Middelkamp, bedankt voor jullie hulp bij de anthropometrie, ECG-en bloeddruk-metingen. Zonder jullie hadden we nooit zoveel mensen op één ochtend kunnen meten. George Ledoux, heel erg bedankt voor je werk in het laboratorium in de laatste periode van het onderzoek.

Marloes van der Molen, Liesbeth van Loon, Noortje Jansen en Martijn Brouwers, mijn wetenschapsstagiaires, bedankt voor al jullie hulp. Marloes, jij kwam als één van de eerste studenten op ons onderzoek af hoewel al snel bleek dat wat we in gedachten hadden helaas niet zou gaan werken. Gelukkig wilde je nog wel stage lopen wat een heel gezellige periode was. Liesbeth, jij wilde zelf data verzamelen en moest de proefpersonen nogmaals oproepen voor de LPL-test die je wilde gaan doen. Vaak kwam je mijn kamer binnengestormd met allerlei vragen over statistiek en metingen die ik ook niet altijd direct kon beantwoorden. Gelukkig konden mijn collega's van het MME-lab je dan wel vaak helpen. Noortje, bedankt voor alle metingen die je hebt verricht en alle berekeningen die je hebt gedaan. Dit laatste was zeker niet de leukste klus, maar toch bleef je altijd vrolijk. Ik kom je vast nog wel eens tegen in de stad of tijdens carnaval! Martijn, ook jij hebt jouw aandeel in de berekeningen gehad waarvoor ik je heel dankbaar ben. Jij kwam vaak met kritische vragen die ervoor zorgden dat ik weer even terug moest denken waarom we bepaalde beslissingen ook al weer genomen hadden. Het is fijn je niet alleen als stagiaire maar ook als collega te hebben leren kennen en dan nog wel een die ook thuis is in de echo-wereld.

Naast Martijn en Carla wil ik ook mijn overige (oud)collega's van het MME-lab bedanken voor hun gezelligheid en interesse in het "diabetes-project": Marleen van Greevenbroek, Steven Meex, Anna Georgieva, Vicky Vermeulen, Josephine van Lin, Margee Robertus, Mohammed Elhasnaoui, Erik Keulen, Riny Wieers en Petra Eurlings. Erik, bedankt voor alle keren dat ik met vragen over het 'echo-en' bij je terecht kon en alle gezelligheid. Riny, zonder jou waren alle metingen nooit afgekomen en was het lang zo gezellig niet geweest op de kamer... Steven, Anna en Martijn, veel succes met jullie proefschrift! Mohammed, bedankt voor je interesse en de vele gezellige discussies over van alles en nog wat.... 
Ook mijn (oud)collega's van Humane Biologie mag ik natuurlijk niet vergeten! Drie jaar heb ik als één van de werknemers bij julllie op de gang mogen zitten. Als eerste wil ik mijn kamergenoten Tanja, Ilse, Marja en Marco bedanken voor alle telefoontjes van de proefpersonen die jullie beantwoord hebben wanneer ik weer eens aan het meten was. Het was echt niet mijn bedoeling jullie secretaresse te laten voelen! Bedankt ook voor alle gezelligheid en steun. Naast mijn kamergenoten had/heb ik ook nog een aantal "kroeggenoten": Jos, Luc, Joost, Freddy, Michiel, Chris en Eefje. Bedankt voor alle leuke momenten! Jos, bedankt voor het bepalen van alle glucose monsters en je hulp bij het labwerk als dat nodig was. Luc, bedankt voor het bijbrengen van de liefde voor het onderzoek. Joost, bedankt voor al je gezelligheid en het delen van alle frustraties rond het afronden van een proefschrift. Freddy, bedankt voor al je steun en gekkigheid. Michiel, bedankt voor al je adviezen en voor je serieuze en laag-nivo gesprekken. Chris, bedankt voor alle video-avondjes. Ook alle andere collega's van $\mathrm{HB}$, zowel nieuw als oud, wil ik heel erg bedanken voor hun steun, interesse en gezelligheid.

Daarnaast wil ik alle mensen die ik ook vaak in de kroeg, op de "uni" of daarbuiten zag en die ik hierboven niet heb genoemd ook graag bedanken voor de zo broodnodige afleiding, o.a. Marjan Smook (het was gezellig je kamergenootje te zijn), Daphne Pannemans (bedankt voor de keren in de kroeg, tijdens carnaval en bij Rowen Heze concerten), Renate de Groot (bedankt voor de avondjes eten en alle kletsjes op de uni), Ron Keulen, Riet Daamen, Joan Senden en vele anderen. Ook mijn collega's van de UM-sport wil ik niet vergeten. Heel erg bedankt voor alle sportieve afleiding!

Naast alle mensen die ik ken via de universiteit en het sportburo heb ik ook nog een druk leven daarbuiten gehad. Ook deze mensen zijn altijd geïnteresseerd geweest en ik kon altijd bij ze terecht voor gezellige avondjes bijkletsen of lekker op stap gaan. Eline, lief vriendinnetje, bedankt voor alle keren dat we zijn wezen stappen en de belangrijke en minder belangrijke zaken des levens bespraken. Ik ben blij dat ik je al 20 jaar (!) mijn vriendinnetje mag noemen. Ruth, pas sinds relatief korte tijd hebben we weer contact na ons "buurmeisjes-verleden", maar het is weer supergezellig! Je bent altijd in voor leuke dingen en ik ga zeker nog eens mee in je bootje varen. Nicole, soms zien en spreken we elkaar langere tijd niet, maar dat maakt niets uit.... we kletsen toch zo weer verder. Ik hoop dat we nog vaak samen op stap gaan. Blanche, allebei houden we veel van praten, dansen en lerse pubs, de ingrediënten voor vele gezellige dagen...ik hoop dat we elkaar nog vaak zien! Ook al mijn overige vriendjes en vriendinnetjes, die ik al vele, vele jaren ken van 'thuis thuis' en die me heel dierbaar zijn, wil ik graag bedanken voor alle gezelligheid en interesse: Daphne en Gerard, Edwin en Marian, Monique en Wijnand, Bas en Anja, Marc en Monique, Theo en Jositha, en Esther en Jaap. Ik ken jullie nu al heel erg lang en hoop nog vele jaren van jullie en jullie kids te kunnen genieten! Mijn oude dispuutsgenootjes mag ik ook zeer zeker niet vergeten. Zij hebben gezorgd voor veel steun, afleiding en gezellige weekendjes. Bedankt daarvoor!

Als laatste wil ik mijn papa, mama, broer(tje) Jan-Willem en zus(je) Rosalie bedanken voor hun onvoorwaardelijke steun en geloof in mij. Zonder jullie was ik nooit de persoon geworden die ik nu ben en had ik niet het doorzettingsvermogen gehad om dit proefschrift tot een goed einde te brengen. 